
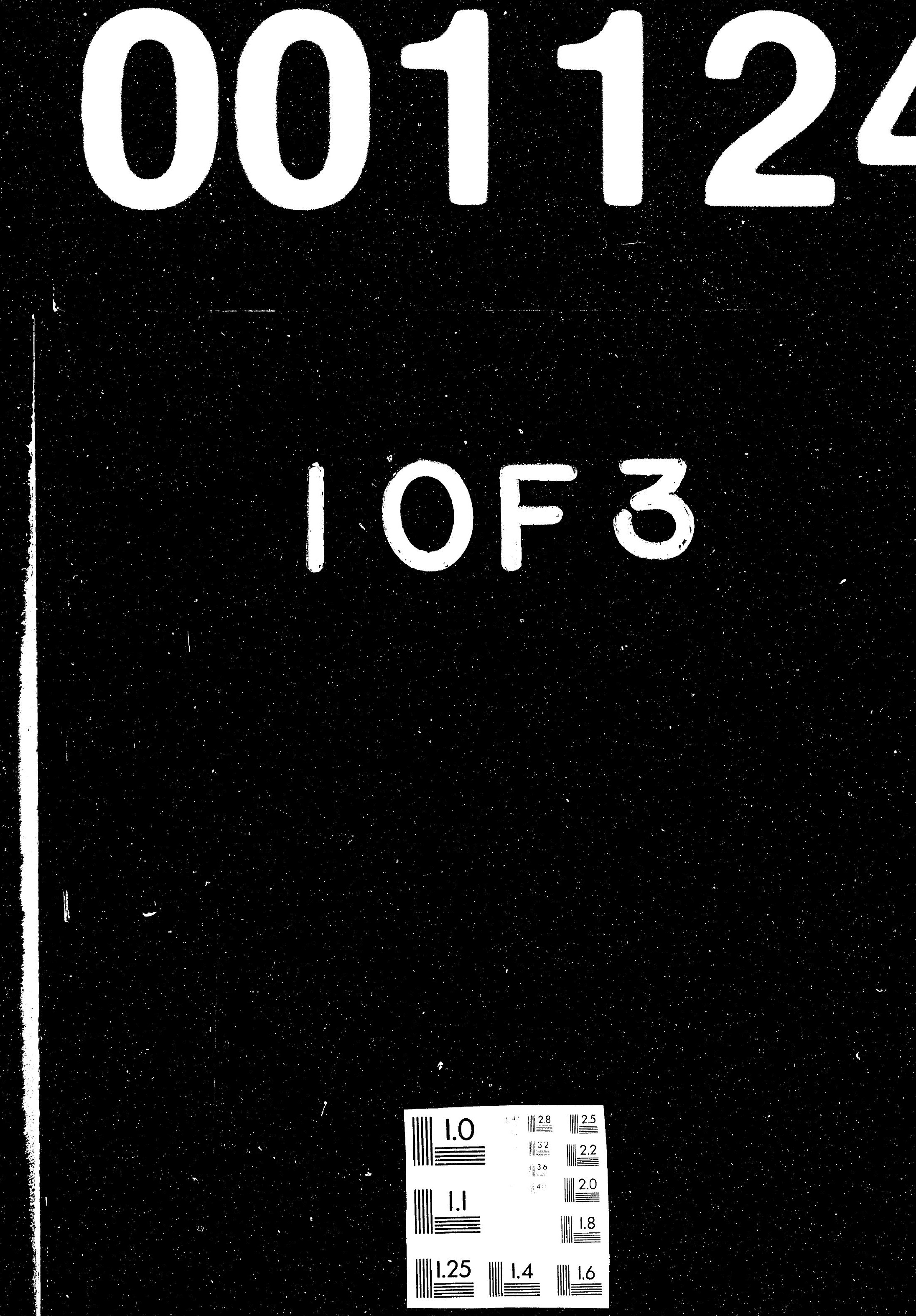

$\checkmark$

3 
DEVELOPMENT OF STANDARDIZED AIR-BLOWN COAL GASIFIER/GAS TURBINE CONCEPTS FOR FUTURE ELECTRIC POWER SYSTEMS

Volume 1

Final Report

By

R. S. Sadowskl

M. J. Brown

J. C. Hester

J. T. Harriz

G. J. Ritz

February 1991

Work Performed Under Contract No. AC21-89MC26291

(4)

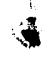

For

U.S. Department of Energy

Morgantown Energy Technology Center

Morgantown, West Virginla

By

CRS SIrrine, Inc.

Greenville, South Carollna 


\section{DISCLAIMER}

This report was prepared as an account of work sponsored by an agency of the United States Government. Neither the United States Government nor any agency thereof, nor any of their employees, makes any warranty, express or implied, or assumes any legal liability or responsibility for the accuracy, completeness, or usefulness of any information, apparatus, product, or process disclosed, or represents that its use would not infringe privately owned rights. Reference herein to any specific commercial product, process, or service by trade name, trademark, manufacturer, or otherwise does not necessarily constitute or imply its endorsement, recommendation, or favoring by the United States Government or any agency thereof. The views and opinions of authors expressed herein do not necessarily state or reflect those of the United States Government or any agency thereof.

This report has been reproduced directly from the best available copy.

Available to DOE and DOE contractors from the Office of Scientific and Technical Intormation, P.O. Box 62, Oak Ridge, TN 37831; prices available from (615)576-8401, FTS 626-8401.

Available to the public from the National Technical Information Service, U.S. Department of Commerce, 5285 Port Royal Rd., Springfield, VA 22161. 


\title{
Development of Standardized Air-Blown Coal Gasifier/Gas Turbine Concepts for Future Electric Power Systems Volume I
}

Final Report

\author{
R.S. Sadowski \\ M.J. Brown \\ J.C. Hester \\ J.T. Harriz \\ G.J. Ritz
}

Work Performed Under Contract No.: DE-AC21-89MC26291

For

U.S. Department of Energy

Office of Fossil Energy

Morgantown Energy Technology Center

P.O. Box 880

Morgantown, West Virginia 26507-0880

\section{By}

CRS Sirrine, Inc.

Power Division

P.O. Box 5456

Greenville, South Carolina 29606-5456

February 1991 
Forward

Acknowledgements

1. Status of Low Btu Gasification Systems for a Standardized

IGCC Gasifier.................................................................... 1

1.1 Summary.......................................................... 2

1.2 Gasifier Concepts

1.2.1. Overview Descriptions of Candidate Gasifiers..................... 2

1.2.1.1 Lurgi Fixed Bed ........................................... 2

1.2.1.2 British Gas/Lurgi (BGL) ............................... 4

1.2.1.3 Lurgi Fluidized Bed ......................................... 5

1.2.1.4 Dow ........................................................... 5

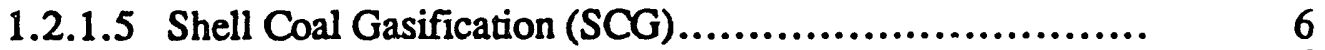

1.2.1.6 Texaco ..................................................... 6

1.2.1.7 MBG Coal Gasification................................... 6

1.2.2. Process Descriptions of Candidate Gasifiers ........................ 7

1.2.2.1 Lurgi Fixed Bed ......................................... 7

1.2.2.2 British Gas/Lurgi (BGL) ................................. 9

1.2.2.3 Lurgi Fluidized Bed ............................................ 10

1.2.2.4 Dow Gasifier.................................................. 11

1.2.2.5 Shell Gasifier......................................................... 11

1.2.2.6 Texaco Gasifiers................................................... 15

1.2.2.7 MBG Coal Gasification................................. 18

1.3 Estimated System Performance

1.3.1 Performance Discussion ............................................... 20

1.3.2 Performance Parameters ............................................. 24

1.4 Issues Affecting Gasifier Performance

1.4.1 Free Swelling Index (FSI)........................................ 29

1.4.2 Ash Fusion Temperatures ............................................ 41

1.4.3 Ammonia \& Cyanide Production ..................................... 41

1.4.4 Volatilized Alkali Production............................................. 41

1.4.5 Tar Production ........................................................ 41

1.4.6 Thermal-phoresis .................................................... 42

1.4.7 Ash Carbon Content......................................................... 42

1.4.8 Pressure Containment............................................... 42

1.4.9 Coal Feed System Losses .......................................... 43

1.4.10 Coal Sizing ............................................................. 43

1.4.11 Turndown ....................................................... 43 
1.5 Gasifier Installation and Agreements ...................................... 43

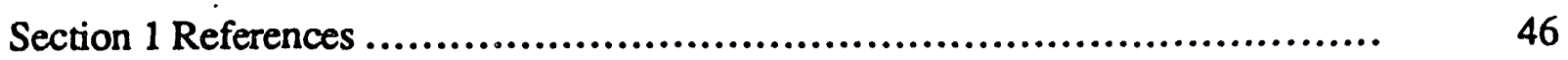

2. Preliminary Assessment of Optimum Combinations of Combustion Turbine and Gasifier/HGCU Hardware ............................................... 48

2.1 Summary ............................................................. 49

2.2. Gas Turbine Selection

2.2.1. Overview Descriptions of Candidate Gas Turbines ................. 50

2.2.1.1 NOxFormation............................................ 52

2.2.1.2 Trace Metal Contaminants............................... 53

2.2.1.3 Fuel Handling System ..................................... 53

2.2.1.4 Fuel Injectors ............................................... 54

2.2.1.5 Compressor Surge ........................................... 54

2.2.2 Cycle Description ................................................. 55

2.3 Estimated Gas Turbine Performance

2.3.1 Characteristics of Fuel Supplisd .................................... 55

2.3.2 Confidence in GTPro through Westinghouse Comparison ......... 57

2.3.3 50MW Cycle ....................................................... 59

2.3.4 100 MW Cycle ...................................................... 59

2.3.5. 200MW Cycle.......................................................... 59

2.4 Issues Affecting Turbine Performance

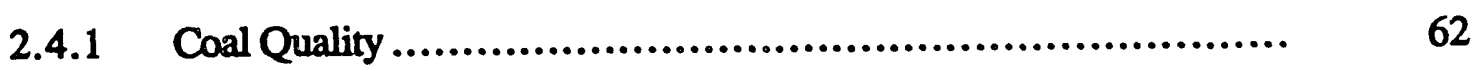

2.4.2 Gasifier Cooling .................................................. 62

2.4.3 Gas Turbine Compressor Surge ..................................... 64

2.4.4 Combustion Turbine Inlet Temperatures.................................... 64

2.4.5 Fuel Inlet Pressure.......................................................... 64

2.4.6 Volatilized Alkali............................................................ 65

2.4.7 NOx Emissions ................................................... 65

Section 2 References .............................................................. $\quad 65$ 
3. Gasifier Design Modifications Required to Accommodate High Free

3.1 Summary........................................................... 67

3.2 Gasifier Selections and Limitations

3.2.1 Overview Descriptions of Candidate Gasifiers.................... 68

3.2.1.1 Air-blown, Fixed-bed, Dry-ash Bottom .................... 69

3.2.1.2 Air-blown, Fixed \& Entrained-bed, Slagging Bottom...... 69

3.2.1.3 PyGas Coal Gasifier .................................... $\quad 74$

3.2.2 Detailed Descriptions of Candidate Coal Gasifiers...................... $\quad 78$

3.2.2.1 Lurgi Mark IV............................................ 78

3.2.2.2 Scaled-up METC Gasifier ....................................... 78

3.2.2.3 Py-Gas Coal Gasifier ................................... 79

\subsection{Estimated System Performance}

3.3.1 Performance Discussion ......................................... 81

3.3.2 Performance Parameters .......................................... 81

3.4 Issues Affecting System Performance

3.4.1 Coal Free Swelling Index (FSI) ............................... 81

3.4.2 Coal Ash Fusion Temperature Characteristics ...................... 82

3.4.3 Gasifier Steam to Coal Ratio ......................................... 82

3.4.4 Coal Sizing ....................................................... 82

3.4.5 Tar Production .................................................... 83

3.4.6 Volatilized Alkali Production............................................. 83

3.4.7 Thermal-phoresis .............................................. 83

3.4.8 Lock Hopper Batch Feeding vs. Continuous Pneumatic Feed...... 84

3.4.9 Gasifier Air to Coal Ratio .............................................. 84

3.4.10 Ammonia \& Cyanide Production ..................................... 84

3.4.11 Ash Carbon Content......................................................... 85

3.4.12 Pressure Containment.................................................. 85

Section 3 References ....................................................... 85

4. Design and Performance of Standardized Fixed Bed Air-Blown Gasification IGCC Systems ......................................................... 88

$4.1 \quad$ Summary............................................................. 89 
4.2 Integration \& Matching of Commercial Gasification IGCC Applications

4.2.1 $50 \mathrm{MW}$ Size for Co-generation \& IPP ......................... 103

4.2.1.1 STAG ................................................. 104

4.2.1.2 STIG ................................................... 113

4.2.1.3 Cost Sensitivity....................................... 120

* STAG \& STIG are Trademarks of the General Electric Company, USA

4.2.2 $100 \mathrm{MW}$ Size CGIA Concept .................................. 120

4.2.2.1 Cogeneration \& IPP Applications ...................... 120

4.2.2.2 Utility Applications....................................... 122

4.2.2.3 Cost Sensitivity...................................... 129

4.2.3. $200 \mathrm{MW}$ Size CGIA Concept .................................. 129

4.2.3.1 Cogeneration \& IPP Applications ..................... 129

4.2.3.2 Utility Applications......................................... 131

4.2.3.3 Retrofit/Repowering of Coal Fired Utility Plant.......... 139

4.2.3.4 Cost Sensitivity.......................................... 153

4.3 Standardized Module Design \& Performance

4.3.1 $50 \mathrm{MW}$ Size for Cogeneration \& IPP ........................... 157

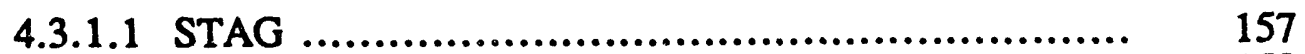

4.3.1.2 STIG .................................................. 159

4.3.2 $100 \mathrm{MW}$ Sized CGIA Plant ....................................... 160

4.3.2.1 Cogeneration \& IPP Applications ..................... 160

4.3.2.2 Utility Applications....................................... 161

4.3.3 200 MW Sized CGIA Plant ................................... 161

4.3.3.1 Cogeneration \& IPP Applications ..................... 161

4.3.3.2 Utility Applications....................................... 162

4.4. Financial Inputs

4.4.1 Cogeneration \& Independent Power Production....................... 163

4.5. Owner's Cost Factors

4.5.1 Construction ...................................................... 164

4.5.2 Working Capital ..................................................... 164

4.5.3 Development ........................................................... 164

4.5.4 Fuel Inventory ..................................................... 164

4.5.5 Financing Fees...................................................... 164

4.5.6 Spare Parts (Initial) .......................................... 164 
4.6. Economic Inputs (Major Only)

4.6.1 General Inflation.................................................... 164

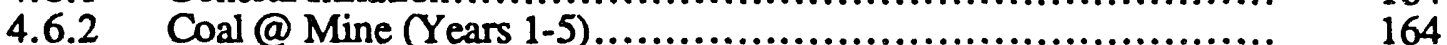

4.6.3 Coal @ Mine (Years 6-20) .......................................... 164

4.6.4 Coal Transportation ................................................... 164

4.6.5 Discount Rate .............................................................. 164

4.6.6 Interest During Construction ..................................... 164

4.6.7 Interest on Primary Debt...................................... 164

4.6.8 Equity After Tax Rate of Return (ATROR)......................... 164

4.6.9 Corporate \& Investor's Tax Rates ................................... 164

4.6.10 Property Tax Rates ................................................ 164

4.6.11 Coal Fuel .......................................................... 164

4.6.12 Natural Gas Fuel................................................. 164

4.6.13 Catalysts ............................................................ 164

4.6.14. Disposal......................................................... 164

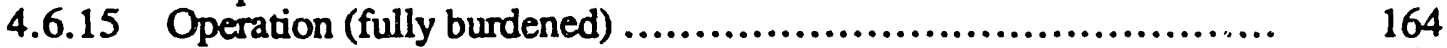

4.6.16 Insurance ............................................................. 164

4.6.17 Cost of Capital
1. Debt Coverage Ratio (Min)(Opn Inc/Pri Debt) .................... 164

2. Subordinated Debt ................................................ 164

3. Owner's Equity................................................. 164

4.6.18 Term of Debt Service................................................... 164

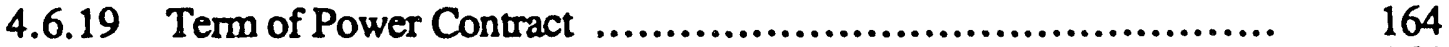

4.6.20 Depreciation Period ......................................................... 164

4.6.21 Depreciation Amount (\% of X-key) ................................... 164

4.6.22 Capacity Factor .......................................................... 164

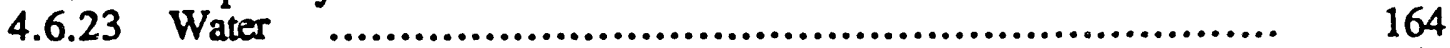

4.6.24 Startup \& Auxiliary Fuel Usage ....................................... 164

4.6.25 Elemental Sulfur Credit .................................................... 164

4.6.26 Sulfuric Acid Credit ................................................. 164

4.6.27 Liquid Sulfur Dioxide Credit....................................... 164

Section 4 References ......................................................... 164

5. Assessment of Standardized Fixed-Bed, Air-Blown Gasifier

IGCC Market Acceptance.

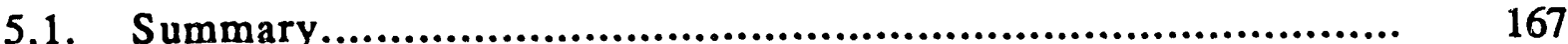

\subsection{Market Acceptance Survey}

1990 Cogeneration \& Independent Power Congress

5.2.1 Survey Questionnaire Results................................. 168

6. Developments Required to Effect Commercial Gasification IGCC

Applications (CGIA) Integration Into the Power Market

6.1. Summary. 
6.2. Integration \& Matching of Commercial \& Utility Gasification IGCC Applications 176

6.3. Standardized Module Design \& Performance Concept...................... $\quad 180$

6.3.1 $50 \mathrm{MWe}$ Cogeneration \& IPP CGIA Design.................... 181

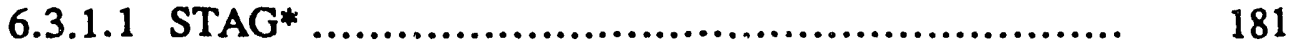

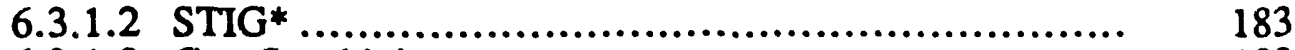

6.3.1.3 Cost Sensitivity....................................... 183

6.3.2 100 MWe STAG Cogeneration/LPP CGIA Design............... 183

6.3.2.1 STAG................................................... 183

6.3.2.2. Utility Configuration...................................... 184

6.3.2.3 Cost Sensitivity......................................... 184

6.3.3 200 MWe STAG Cogeneration/IPP, Utility CGIA Design......... 184

6.3.3.1 STAG.................................................. 184

6.3.3.2. Utility Configuration....................................... 184

6.3.3.3 Cost Sensitivity ........................................ 184

6.3.4. Utility Industry Applications .................................. 185

6.3.4.1 Retrofit/Repowering ...................................... 185

6.3.4.2 New Utility Applications .................................. 190

6.3.4.3 Cost Sensitivity ........................................... 190

6.4. Independent Agency Overview and Licensing ........................... 192

6.4.1 The Licensing Concept............................................. 192

6.4.1.1 Electric Power Research Institutes (EPRI) .............. 192

6.4.1.2 Alternative Agency Considerations.......................... 192

6.4.2 The Opportunity Window ....................................... 193

* STAG \& STIG are Trademarks of the General Electric Company, USA

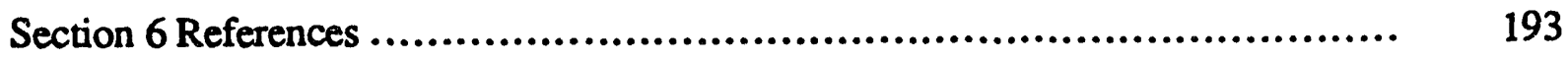




\section{List of Figures}

SECTION 1:

Page

$1 \quad$ Lurgi Pressurized Gasifier............................................ 21

2 Chemical Reactions Occurring in a Fixed-Bed Gasifier...................... 25

3 Comparison of Measured \& Predicted Temperature \& Concentration Profiles Throughout a Fixed Bed Gasifier.

$4 \quad$ Lurgi Pressure Gasifier \& Its Operating Properties During

Coal Gasification.

$5 \quad$ Lurgi Gasifier Gas Production ........................................ 36

6 Empirical Gasifier Output Prediction ...................................... 38

7 Actual Volatilized NaCl AFO Anticipated Gasification Temperatures ......... 39

8 Actual Volatilized $\mathrm{NaCl} \& \mathrm{KCl}$ AFO Anticipated Gasification Temperatures 40

\section{SECTION 2:}

1 Gas Turbine Combined Cycle Integrated with Air Blown

Fixed Bed Gasifier.................................................................

\section{SECTION 3:}

1 General Arrangement Front Elevation Coal Fired Low Btu Gasifier/HGCU ................................................................. 70

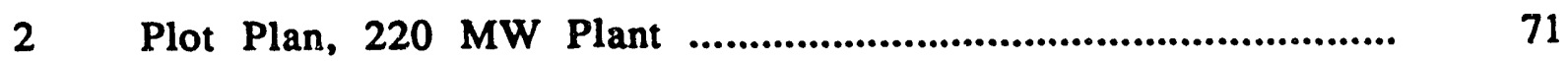

$3 \quad$ Lurgi Pressure Gasifier ................................................. 72

4 Sectional View of Current METC Fixed-Bed Gasifier...................... 73

$5 \quad$ Molten Slag Tap Type Utility Pulverized Coal Fired Boilers................. $\quad 75$

6 Actual Volatilized NaCl \& $\mathrm{KCl}$ AFO Anticipated Gasification

Temperatures ................................................................. 76

$7 \quad$ The L.C. Energy PyGas Producer................................................ 77

8 Illustration of Devolatilization \& Agglomeration........................... 80 


\section{List of Figures - continued}

\section{SECTION 4:}

1 Combined Gasification IGCC Applications (CGIA) .................... 92

2 Low Btu Gas Analysis vs. Water Content............................. 97

3 Cost of Electricity vs. Capacity Factor ................................. 101

$4 \quad$ Empirical Gasifier Output Prediction .................................... 102

$5 \quad$ Air-Blown Fixed Bed IGCC Pant Costs................................ 104

$650 \mathrm{MW}$ Cogeneration Schematic....................................... 105

$7 \quad$ Plant Cost Sensitivity GE-LM/TG5000PC, 45 MWe CGIA N'th Plant...... 107

$850 \mathrm{MW}$ STIG Schematic............................................... 114

9 Plant Cost Sensitivity GE-LM/TG5000 STG, 46 MWe CGIA N'th Plant ... 115

$10100 \mathrm{MW}$ Cogeneration Schematic ...................................... 121

11 Plant Cost Sensitivity GE7111EA, 120 MWe CGIA N'th Plant............... 123

$12100 \mathrm{MW}$ Utility Schematic................................................... 124

$13200 \mathrm{MW}$ Cogeneration Schematic ....................................... 130

14 Plant Cost Sensitivity GE7191F, 223 MWe CGIA N'th Plant................. 132

$15200 \mathrm{MW}$ Utility Cycle Schematic ......................................... 137

16 Plot Plan 50 MW Plan....................................................... 138

17 Plot Plan 100 MW Plan ................................................. 140

18 Plot Plan $200 \mathrm{MW}$ Plan ................................................. 141

19 General Arrangement Front Elev. Coal Fired Low Btu Gasifier/HGCU Module........................................................................ 142

20 General Arrangement Side Elev. Coal Fired Low Btu Gasifier/HGCU Module .................................................................. 143

21 DOE Reference Plant IGCC Retrofit ReSOx Concept............................ 145

$22500 \mathrm{MW}$ Retrofit/Repowering with IGCC Arrangement Plan................... 146

23 Plant Cost Sensitivity, 575MW CGIA Retro/Repower, N'th Plant .......... 154 


\section{List of Figures - continued}

24 Air-Blown Fixed Bed IGCC Pant Costs CGLA with PyGas Gasifier........ 155

25 Cost of Electricity vs. Capacity Factor

(223 MWe PyGas CGIA GE7191F, N'th Plant)......................... 156

\section{SECTION 6:}

$1 \quad$ Low Btu Gas Analysis vs. Water Content............................. 177

$2 \quad$ Plant Standardization Concepts ...................................... 182

$3 \quad$ Plant Cost Sensitivity GE7191F, 226 MWe CGLA N'th Plant................. 185

$4 \quad$ Air-Blown Fixed-Bed IGCC Plant Costs................................ 191 


\section{List of Tables}

Page

SECTION 1:

1 Fixed-Bed Gasification Commercially Proven ............................... 4

$2 \quad$ Lurgi Performance Characteristics...................................... 7

3 Shell Gasifier Output Composition .................................... 15

4 Texaco Gasifier Characteristics ......................................... 17

5 Dry Bottom Lurgi Concept ........................................ 23

6 Estimated Lurgi Air Blown Characteristics ............................... 28

$7 \quad$ GE Data for Fixed Bed Gasifier Performance............................. 30

8 Typical Lurgi Performance Data for Air-Blown Operation ................... 31

$9 \quad$ Performance Characteristics of Moving-Bed Gasifiers............................ $\quad 32$

10 Process Data and Gas Produced for the Lurgi Gasifier ...................... 33

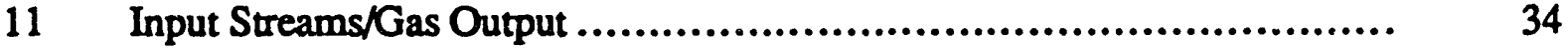

12 Gas Composition and Heating Value for Typical Air-Blown

Low-Btu Gasifiers........................................................... 35

13 Normalized Fixed Bed Gasifier Output Performance.............................. 37

14 Estimated Coal Gasification Capital Costs.................................. 45

\section{SECTION 2:}

$1 \quad$ Nominal ISO No Loss Performance on CH4 ........................... 51

2 Selected Combustion Turbine Models for 50MW, 100MW, \& $200 \mathrm{MW}$ IGCC.

3 Gas Turbine Manufacturers' Sodium \& Potassium Limits..................... 53

4 Numbers of Modules Required for 50MW, 100MW, \& 200MW IGCC Plants

5 Analysis of Raw Coal \& Coal Gas Produced

6 Comparison of Gas Turbine Predicted Performance on Low Btu Fuel .......

750 MWe IGCC Performance Sensitivity with Ambient Temperature. 


\section{List of Tables - continued}

8a 100 MWe IGCC Performance Sensitivity w/Ambient Temp. GE7111EA.... 60

8b 100 MWe IGCC Performance Sensitivity w/Ambient Temp. MW501-D5 ... 61

8c 100 MWe IGCC Performance Sensitivity w/Ambient Temp.ABBGT11N... 61

9a 200 MWe IGCC Performance Sensitivity w/Ambient Temp. GE7191F...... 63

9b 200 MWe IGCC Heat Rate \& Fuel Flow Sensitivity w/Ambient Temp. MW501-F 63

\section{SECTION 3:}

1 Generic Coal Gasifier Features............................................... 68

\section{SECTION 4:}

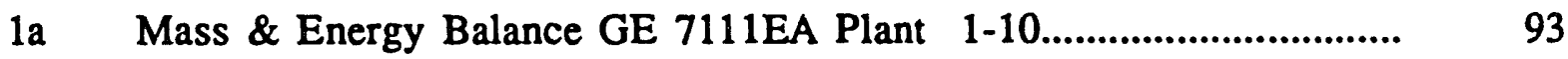

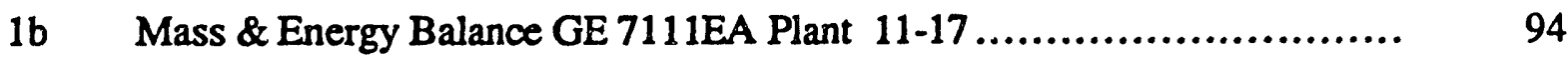

1c Mass \& Energy Balance GE 7111EA Plant 18-24 ........................ 95

1d Mass \& Energy Balance GE 7111EA Plant 25-28 ....................... 96

2 Availability Analysis, 4 Parallel Units............................................. 98

3 Availability Analysis, 2 Parallel Units......................................... 99

$4 \quad$ Availability Analysis, 8 Parallel Units........................................... 100

5a IGCC Plant Costing, 45 MWe Summary.................................. 108

5b IGCC Plant Costing, 45 MWe Cogen System Group........................... 109

5c IGCC Plant Costing, 45 MWe Coal Gasification Adders....................... 110

5d IGCC Plant Costing, 45 MWe Turnkey Construction Cost................. 111

5e IGCC Plant Costing, 45 MWe Installed Project Total...................... 111

5f IGCC Plant Costing, 45 MWe Cost of Electricity ........................ 111

$6 \quad$ IGCC Plant Costing, Financial Input Assumptions ......................... 112

7a IGCC Plant Costing, 46 MWe Summary................................ 116

7b IGCC Plant Costing, 46 MWe Cogen System Group........................... 117 


\section{List of Tables - continued}

7c IGCC Plant Costing, 46 MWe Coal Gasification Adders....................... 118

7d IGCC Plant Costing, 46 MWe Turnkey Construction Cost................. 119

7e IGCC Plant Costing, 46 MWe Installed Project Total........................... 119

7f IGCC Plant Costing, 46 MWe Cost of Electricity ......................... 119

8a IGCC Plant Costing, 120 MWe Summary .............................. 125

8b IGCC Plant Costing, 120 MWe Cogen System Group ...................... 126

8c IGCC Plant Costing, $120 \mathrm{MWe}$ Coal Gasification Adders ................... 127

8d IGCC Plant Costing, 120 MWe Turnkey Construction Cost.................... 128

8e IGCC Plant Costing, $120 \mathrm{MWe}$ Installed Project Total ...................... 128

8f IGCC Plant Costing, 120 MWe Cost of Electricity................................ 128

9a IGCC Plant Costing, 120 MWe Summary ................................ 133

9b IGCC Plant Costing, 120 MWe Cogen System Group ...................... 134

9c IGCC Plant Costing, $120 \mathrm{MWe}$ Coal Gasification Adders ................... 135

9d IGCC Plant Costing, i20 MWe Turnkey Construction Cost.................... 136

9e IGCC Plant Costing, $120 \mathrm{MWe}$ Installed Project Tota1 ..................... 136

9f IGCC Plant Costing, 120 MWe Cost of Electricity.............................. 136

10a Retrofit/Repower IGCC Plant Costing, Generic Plant,

GE7191F, 575 MWe Summary................................................ 148

10b Retrofit/Repower IGCC Plant Costing, Generic Plant,

GE7191F, 575 MWe Cost of Electricity................................... 149

10c Retrofit/Repower IGCC Plant Costing, Generic Plant,

GE7191F, 575 MWe Cogen System Group ............................... 150

10d Retrofit/Repower IGCC Plant Costing, Generic Plant,

GE7191F, 575 MWe Coal Gasification Adders

10e Retrofit/Repower IGCC Plant Costing, Generic Plant,

GE7191F, 575 MWeTurnkey Construction Cost.............................. 152

10f Retrofit/Repower IGCC Plant Costing, Generic Plant,

GE7191F, 575 MWe Installed Project Total 


\section{List of Tables - continued}

11 Auxiliary Power Losses (@ 123.1 MWe).................................. 157

12 Performance Characteristics of a 50 MWe CGIA Plant ....................... 158

13 Performance Characteristics of a 50 MWe STIG CGIA Plant.................. 159

14 Performance Characteristics of a 100 MWe Cogen/IPP Type CGIA Plant... 160

15 Performance Characteristics of a 100 MWe Utility Type CGIA Plant......... 161

16 Performance Characteristics of a 200 MWe CGIA Plant......................... 162

17 Performance Cnaracteristics of a 200 MWe Utility Plant ................... 163

\section{SECTION 5:}

1 Questionnaire "Is Coal in Our Future", Results............................ 168

\section{SECTION 6:}

1 Cost of Electricity Retrofit/Repower IGCC, GE7191F, 575 MWe............ 178

2a IGCC Plant Costing @ 226 MWe Summary ............................... 186

2b IGCC Plant Costing @ 226 MWe Cogen System Group........................ 187

2c IGCC Plant Costing @ 226 MWe Coal Gasification Adders.................... 188

2d IGCC Plant Costing @ 226 MWe Turnkey Construction Cost............... 189

$2 e \quad$ IGCC Plant Costing @ 226 MWe Installed Project Total........................ 189

2f IGCC Plant Costing @ 226 MWe Cost of Electricity ......................... 189 


\section{Appendix A}

"Fixed Bed Gasifier and Sulfur Sorbent Regeneration Subsystem Computer Model Development", by Eric Blough, William Russell, \& James W. Leach, North Carolina State University, Raleigh, N.C.

\section{Appendix B}

"NOx and Alkali Vapor Control Strategies", by PSI Technology Company, 20 New England Business Center, Andover, MA

\section{Appendix C}

"Design and Performance of Standardized Fixed Bed Air-Blown Gasifier IGCC

Systems", by Michael J. Brown, J. Thomas Harriz, \& Richard S. Sadowski, C.R.S. Sirrine, Inc., Greer.ville, South Carolina

\section{Appendix D}

"Cost Support Information", by C.R.S. Sirrine, Inc., Greenville, South Carolina

\section{Appendix E}

"Fixed Bed Air-Blown Gasifier IGCC System Equipment List",by C.R.S.Sirrine, Inc., Greenville, South Carolina 


\section{Acknowledgements}

This report was prepared by C.R.S. Sirrine Engineers, Inc., who wishes to acknowledge the participation and support assistance of the following contributors:

\section{CONTRIBUTORS}

Traci D. Atkinson

Rick J. Cashatt

Nathaniel Dunlap III

Stan M. Greene

Gordhan Hirani.

Mark E. Kunkel.

Michael A. McDavid

Edward T. Ostrowski

Wanda W. Smith.

Michael E. Voss
Michael J. Brown

Anthony J. Cipriani

J.Charles Hester

Donnie R.Griffin

Christy C.Jarvis

C. Murray Lane

William $\mathrm{H}$. Nelson

George J. Ritz

Janet K. Stafford
Harold B. Burnham

Brian R. Cripps

Michael T. Feeney

J. Thomas Harriz

Mark Khesin

Ron J. Lawler

Eric S. Norris

Larry J. Romero

J.Thomas Templeton 


\section{Executive Summary:}

The objective of this study is to develop standardized air blown fixed bed gasification hot gas cleanup integrated gasifier combined cycle (IGCC) systems.

The standardized IGCC gasifier system is to be compatible with three sizes of coal plants, $50 \mathrm{MW}(\mathrm{e}), 100 \mathrm{MW}(\mathrm{e})$, and $200 \mathrm{MW}(\mathrm{e})$. It is to be operated so as to produce hot raw gas intended for hot gas cleanup and direct combustion in a gas turbine without quenching.

The data reviewed was developed principally by the Department of Energy's Morgantown Energy Technology Center (METC), General Electric (GE), the Lurgi Corporation, Westinghouse, Asea Brown Boveri, Thermoflow. and British Gas Corporation, and the Electric Power Research Institute (EPRI). The data generated was developed principally by C.R.S.Sirrine, Inc. utilizing the GTPro and Mesa combustion turbine and steam cycle performance programs, North Carolina State University, and Physical Sciences Incorporated.

Historical information reveals that maximum coal inputs (hence raw gas outputs) to fixed bed systems vary significantly due to wide ranges in coal reactivity, caking and ash fusion characteristics. Gasification outputs appear to be reduced to less than $50 \%$ of rated capacity when operating on highly caking and low fusion coals. Gas compositions vary with coal composition as would be expected. However gas composition also varies greatly based upon steam use rates which are governed by ash fusion temperatures and in some cases grate cooling requirements.

In attempting to understand fixed bed performance several gasifier concepts currently at, or near commercially developed, were evaluated. Available gasifier options considered include entrained bed, fixed bed slagging gasifiers, fixed bed non-slagging gasifiers, and a steam fluidized bed gasifier. These were evaluated against desired IGCC criteria with the result that no available gasifier completely meets all the criteria. The Lurgi Mark IV fixed bed non-slagging bed gasifier comes closest to meeting all of the governing criteria.

Gas turbine compressor surge is a potential limiting factor in power output and efficiency when applied to the steam cooled air-blown fixed-bed coal gasification IGCC system. Water injection for gasifier temperature control reduces this concern.

Although historical information reveals that maximum coal inputs (hence raw gas outputs) to fixed bed systems vary significantly due to wide ranges in coal reactivity, caking and ash fusion characteristics, the selection of standardized modular components assumes the 
successful near term development of air-blown fixed bed gasifiers capable of operation without sapacity reduction due to coal quality changes over the range of US coals contemplated.

It has been determined that the formation of stickey tars and asphaltines during the devolitization process is the main cause of subsequent agglomeration leading to channeling, reduced coal/air/steam reactions, and hence output capacity reductions. Two approaches to dealing with this problem are postulated herein. The first provides for a mechanical means of breaking up agglomerates as and once they have formed. The other is aimed at preventing the inception of agglomeration.

The results of this study indicate that although the anticipated first system costs will be relatively high, the assumption of pre-engineered standardized and modularized systems for Commercial Gasification IGCC Applications (CGIA) systems results in an "Nth unit" total facility cost of under $\$ 1,000 / \mathrm{kwn}$ in sizes larger than $200 \mathrm{MWe}$. The resultant ten year levellized cost of electricity (COE) reflec:ed the low CGIA standardized plant cost advantage.

This study also identified existing coal fired utility power plants as near term candidates for standardized CGIA application. While many consider conventional flue gas scrubbers as the economical solution to the emissions concerns of large coal fired utilities, such systems are expensive and adversely affect power plant efficiency by consuming significant quantities of power which would have otherwise been available to the grid. In effect, while reducing stack emissions, scrubbers return reduced plant electricity output for their significant expense. Retrofitting and repowering existing coal fired power plants with CGIA results in much lower emissions than currently available commercial scrubber systems plus very substantial increased power output for the same coal input for which the facility has already been designed.

There is solid justification for the consideration of the addition of CGIA systems to existing coal fired utility plants. The majority of the most costly of the capital cost items of the power plant already exist. These include coal receiving/handling/storage/reclaim, water sourcing/purification/treatment/disposal, electricity generation/conditioning/distribution, and the most costly of all, the boiler island itself. Unlike other repowering strategies which require replacement of the boiler island, this study presents a way to simply add on the IGCC system to the existing coal plant with minimum modification to the existing infrastructure. The result is an approximate $20 \%$ increase in power output while reducing 
the plant's stack gas emissions by in excess of $99 \%$ for SO2, 95\% for NOx, $99+\%$ for particulates, and $25 \%$ for $\mathrm{CO} 2$.

A survey, in the form of a questionnaire, was also conducted at the 1990 Cogeneration and Independent Power Production Congress held in Boston, Massachusetts. The majority of the survey respondents had utilized coal in the past $(63 \%)$ and present $(50 \%)$, and a greater majority $(75 \%)$ expected to be burning some coal in the future. While most $(75 \%)$ believe coal is presently environmentally safe to burn, all (100\%) believe coal will be environmentally safe to burn by the year 2000 . Most (63\%) do not expect to burn more coal annually in the next ten years.

The average expected turnkey capital cost for an IGCC coal fired plant was $\$ 1340 / \mathrm{kWn}$. Additionally, the largest group (although all were minority preferences - 23\%) would prefer to purchase their coal combustion and emissions control equipment from Babcock \& Wilcox.

Two thirds would prefer to license coal combustion and emissions control technology from the Electric Power Research Institute (EPRI). In this case, they would expect to then select their own equipment supplier who would furnish the equipment under an EPRI license.

When given a choice of environmental, efficiency, and cost factors, the respondents' were primarily cost conscious, particularly with "cost of electricity". The environment was of secondary importance, and efficiency third. The vast majority (88\%) would buy a coal fired facility if (question 8 ) its cost of electricity was $5 \notin / \mathrm{kwh}$, plant cost was $\$ 1,000 / \mathrm{kwn}$, FERC efficiency was $38 \%$ (or utility cycle efficiency was $41 \%$ ), it had $99 \%$ sulfur removal, its NOx emissions were $0.1 \mathrm{lb} / \mathrm{MBtu}$, and it produced elemental sulfur as a marketable waste product.

The business and financial communities require firm guarantees of unit performance, the proof of which must be borne out under the scrutiny of their own independent "due diligence" engineering reviews. Therefore, although the " $N$ 'th" unit will be financeable, the initial units which will be required to demonstrate satisfactory performance must be innovatively developed and financed.

The standardized IGCC gasifier system is to be compatible with three sizes of coal plants, $50 \mathrm{MW}(\mathrm{e}), 100 \mathrm{MW}(\mathrm{e})$, and $200 \mathrm{MW}(\mathrm{e})$. It is to be operated so as to produce hot raw gas 
intended for hot gas cleanup and direct combustion in a gas turbine without quenching the gas.

The data reviewed was developed from the principal investigator's experience in the development of stoker, pulverized and fluidized coal combustion systems in the cogeneration and independent power production (IPP) industries. In addition, information developed by the Department of Energy's Morgantown Energy Technology Center (METC), CRS Sirrine, Inc., and that of a number of cogeneration and independent power production developers have been subjectively evaluated in the development of this study.

The "Commercialization Plan" contemplated for this emerging product to serve a burgeoning power production market was developed with the recognition that first unit implementation looms as the greatest threat to timely introduction of this concept for widespread use in the cogeneration, independent power production, and utility industries. It includes an unorthodox approach to licensing via the Electric Power Research Industry (EPRI) or a similar independent organization capable of unbiased evaluation and sanctioning of desirable technological concepts for faster implementation of the CGIA technology scherne in the earliest possible timeframe. Process guarantees are expected from the system developer while hardware and performance guarantees are from subsystem equipment manufacturers.

It is also sensitive to the ongoing developmental efforts by others such as those under the DOE's Clean Coal Technologies program. Such heroic efforts to demonstrate full scale novel clean coal utilization technologies should be lauded and supported in every conceivable way.

In the spirit of working along a slightly different path from the norm, this plan for commercialization takes some seemingly widely divergent (however necessary) routes to expidite the process of development, demonstration, and bringing the concept to an industry that would like to immediately implement it if it could be considered technologically proven and thus financeable.

Since additional development of a fixed bed gasifier is currently needed before the economic goals of this study can be realized, it is believed that the cogeneration, independent power production, and utility industries will not endorse it until such time that the improved gasifier is demonstrated. Therefore, this study proposes the retrofitting/repowering of either an existing coal fired utility facility which is perhaps 
nearing retirement, or a similar cogen/IPP facility as the fastest route to achieve commercial status. An existing coal fired facility is appropriate because it presumably already contains most of the infrastructure necessary to support a coal gasification endeavor.

Once commercial status is reached, it is proposed that an independent utility industry representative organization evaluate the demonstrated CGLA retrofitted plant, and using its own criteria, agrees to sanction the technology (assuming it is acceptable). The developer of the CGIA technology would then merely license the technology to the utility industry through the third party (EPRI or equal). In this manner, any utility user could select the builder of the plant who would license it through the industry representative from the CGIA developer. Therefore, if utility A prefers vendor AA to build the plant perhaps because vendor AA previously had built the existing facility, vendor AA would pay a license fee through EPRI to the CGIA developer (similar to the way Lurgi licenses their gasifiers). The value of this scenario is its ability to immediately implement the CGIA concept simultaneously to all users through all qualified vendors. This maximizes CGIA utilization. Since the CGLA developer would provide process guarantees and equipment manufacturers the hardware and performance guarantees, the third party licensing authority would provide only their sanction of the technology (no guarantee liability).

Coal gasification processes are even more difficult to classify and categorize than coal combustion processes because it seems more schemes are contemplated for gasification than for combustion. Some gasification systems contemplated might begin with fixed beds and lump coal, then graduate to crushed coal which allows a range from slug flow to fast elutriative systems to be plausible. Finally, pulverized coal systems typically with molten slag tapping rounds out this array of processes under consideration.

For purposes of this report, the various types of coal gasification schemes have been divided into three classes: entrained, fluidized and fixed bed types.

Consideration was given to the attributes of the various gasifier types consistent with how well each type is perceived to be capable of handling each of a significant number of potential constraints. The summary table following rates the gasifier types from the perspective of the specific boundaries of this contract (ie. Air Blown, Hot Gas Cleanup, FSI $=8$, all US Coals, AFR Reducing 1900F to 2700F+, Run of Mine Coal Size, Pressure to 600 psia). 
Experience with fixed beds and the MBG fluid bed operating on caking coals has not been encouraging. Allowing for the development of a stirrer mechanism and longer residence time in the MBG raised our rating in this category to "fair". Both the entrained beds and PyGas were rated "excellent" since both feed crushed or pulverized c al in a manner which averts the adverse consequences of agglomeration due to caking of highly swelling coals.

Since the Lurgi gasifier has a long history of succerssfully dealing with all but the lowest coal ash fusion range characteristics by carefully controlling bed temperature, it received a "good" rating in this category. Since PyGas also overtly controls bed temperature while also preventing agglomeration (unlike other fixed bed gasifiers), it received an "excellent" rating. Entrained beds received a "poor" rating since historcally, air blown pulverized coal fired utility boilers have demonstrated the inability to maintain molten ash taps for the majority of coals ir. the USA. Fluid Beds also received a "poor" rating, but for just the opposite reason to entrained beds. It is known that low fusion temperature coals suffer from agglomeration and subsequent clinkering in fluid bed combustors in an oxidizing atmosphere. Adding to this the lowering of the fusion temperature of most US coals in a reducing atmosphere results in added concern.

Tar production is a valid concern for caking coals in fixed beds resulting in only a "fair" rating. A "poor" rating was averted only by virtue of the hope that some fixed bed garifiers might effectively recycle tars back to the gasifier "hot zone". Since PyGas does force the products of pyrolysis through the "hot zone" it received an "excellent" rating. Since entrained beds operate at high enough temperatures to crack any forming tars, they also received an "excellent" rating. Fluid beds operate at the lowest temperature of any of the gasifier types which adversely affects their ability to crack tar. According to MBG, their fluid bed requires twenty seconds to crack tars formed by caking coals. Since other fluid bed advocates believe that tars can be cracked at the $1600 \mathrm{~F}$ operating temperature (given sufficient residence time) it was felt that a rating of "good" was justified.

The hotter the gasification process, the greater the potential for volatilized alkali production. Therefore the entrained bed types rated "poor" in this category. Fluid beds also rated "poor" even though they produce considerably less volatilized alkali than entrained beds because of the tight restrictions placed on these trace metals by turbine considerations. This is compounded by the high fines carryover of fluid beds and the likelihood that sub-micron fines will evade collection devices and carry condensed alkali to 
the turbine where it can re-volatilize and condense on turbine blades. Fixed beds rated "good" since most of the alkali volatilized becomes condensed carrying over fines at the low temperatures associated with fixed bed gasifiers. PyGas rated "excellent" because it forces any volatilized alkali to pass through the ash bed as endothermic reaction cooling causes alkali condensation onto the exiting ash. In addition, ash constituents known to promote alkali removal exist in sufficient quantities in many coal ashes to effectively catalyze the process in the PyGas case.

Erıtrained beds rated "poor" on air blown limitations strictly due to the previously identified air blown pulverized coal fired utility experience of limited coal tapability characteristics. This limitation would not exist for oxygen blown entrained beds (oxygen blown is preferred by most entrained bed gasifier protagonists) due to the considerably higher operating temperatures attendant with oxygen gasification. Fixed beds were rated "good" because of sufficient past known operating experience of air blown systems. Both the fluid bed and PyGas types were rated "excellent". Fluid beds because of their past operational successes when air blown in oxidizing atmospheres, and PyGas because of its past successful experience with air blown pyrolyzers, and since it provides for such careful control of its process temperature when air blown.

Fixed beds were rated "fair" with respect to surge margin limitations because a significant amount of operating data required high enough steam flows for bed cooling to exceed gas turbine compressor surge margin limitations. The remaining three gasifier types were all rated "excellent" since they all are capable of minimizing the amount of steam fed to the gasifier.

Eines carry over from the gasifier is the first of the less significant potential constraints of gasifiers. In this regard, both the fixed and fluid beds were judged "poor" because fluid beds have inherently high fines carryover and many fixed beds feed coal very near to where product gas exits enhancing carry over potential. The entrained beds were rated "excellent" due to their unique molten ash particulate removam mechanism. PyGas was also rated "excellent" since coal fines must traverse through a torturous path where they tend to accumulate and exit with the ash rather than make the low velocity sweeping turn to exit with the coal gas.

Entrained beds produce very high exit temperature which earned them a "poor" rating as the hot gas cleanup unit (HGCU) ideally requires approximately 1200 degrees F gasifier exit temperatures. Cooling the coal gas with water spray potentially produces too 
much water vapor for the gas turbine, and cooling via heat exchangers shifts energy recovery toward the Rankine and away from the preferred Brayton thermodynamic cycle. Fixed beds produce lower than optimal exit temperatures especially for high moisture coals such as sub bituminous coals and lignites. For this reason, they were also rated "poor". Fluid beds were judged "fair" because at $1600 \mathrm{~F}$ less cooling is required $\mathrm{r}$ reach the optimum exit temperature. PyGas was rated "excellent" owing to its ability to control its exit temperature to produce the optimum temperature for the HGCU inlet.

Entrained beds rated "excellent" for carbon utilization as they have demonstrated very low carbon content in the quenched bottom ash. Fluid beds rated "poor" because it is known that they require additional ash combustion in a separate burner to consume the high carbon remaining within their residual ash fraction. Fixed beds rated "good" since they have a reasonably good experience record of ash carbon minimization under optimized operating conditions. PyGas also rated "excellent" because it operates with similar residence times to fixed bed gasifiers while exposing much more coal surface area in the form of porous pyrolyzed char to promote carbon utilization. In addition, PyGas provides for a carbon burnout zone just above the grate similar to other fixed bed gasifiers.

Thermal-phoresis potential is greatest for the fixed bed gasifier type which consequently rated "poor" in this category because of low exit temperatures combined with uncracked volatilized tar in its product gas. Fluidized beds rated "good" because although their operating temperature and geometry tends to indicate at least some probability of tar escape with the product gas, they may develop long enough residence times to crack the tar as postulated by the MBG gasifier. The entrained bed and PyGas rated "excellent" here since they both operate at sufficiently high temperatures to crack any tars and keep exit piping sufficiently hot.

Both the entrained and fluid bed gasifiers rated "good" for ammonia and cyanide production minimization because although they both produce the nitrogen bearing compounds, their ability to minimize water content will likely keep such generation to a reasonable minimum. Fixed beds rated "poor" due to their past history of relatively high production rates of these nitrogenous compounds particularly when higher steam flows are required. Since PyGas minimizes steam introduction into the gasification process, it minimizes ammonia and cyanide generation.

Even though the batching process is a negative feature, fixed bed gasifiers were judged "excellent" for pressure containment entirely due to Lurgi's past successes at up to 
600 psia operating pressures. The other types of gasifiers were all rated "good" because they have yet to consistently $c$ monstrate up to 600 psia containment. The other types do have the ability to improve upon the fixed bed batch feeding concept, because they are inherently continuous feed processes which can be operated in an oxidizing (pneumatic feed) mode at relatively low coal feed temperatures.

Since most fluid and fixed bed gasifiers introdıce coal via lock hoppers adjacent to the gasification vessel hot raw gas enters the lock hopper each time coal is fed into the gasifiers. This then requires a sophisticated and relatively expensive purge system to insure the hot raw gas does not leak into the raw coal feed system. This earned both a "poor" rating in the category of coal feed system losses. Both entrained and PyGas coal feeds are continuous and are pressurized far upstream of the gasifier vessels where no hot raw gasses can accumulate. This alleviates their systems from coal gas related losses, hence they are both rated "excellent" in this category.

Gasification capacity is lngically a function of operating temperature which tends to hasten the required reactions. Therefore, entrained bed gasifier types are rated "excellent", while fluidized bed types are rated "poor" since their's has the lowest peak operating temperature. Although they operate at approximately $2300 \mathrm{~F}$ peak temperatures, fixed bed gasifiers are only rated "fair" because they gasify lump sized coal which is somewhat slow to react. PyGas rates "good" because it operates at the temperature and residence time of a fixed bed gasifier and the coal size gradation of a fluid bed while exposing much more coal surface area in the form of porous pyrolyzed char to promote carbon utilization.

Since entrained bed gasifiers must maintain very hot molten conditions to tap their slag formations, they are likely to have only "fair" turndown capability. Since fluid bed gasifiers are limited by fluidization velocities, they too rate only "fair" in turndown capability. Fixed bed gasifiers have historically beer zapable of reasonably "good" turndown of in excess of 2 to 1 . Similarly, PyGas is expected to function much like a fixed bea gasifier from a turndown standpoint. Since its pyrolyzer section has been demonstrated to be capable of operating in excess of 5 to 1 turndown, it was also rated "good" in that category.

An item unrated in the summary table, but a very important issue is efficiency. IGCC systems which maximize the Brayton thermodynamic cycle, and those in combination with Rankine thermodynamic cycles which minimize stack oxygen will tout the highest 
efficiency. Hot gas cleanup units (HGCU) for sulfur capture also minimize system heat loss without concern for low temperature corrosion attendant with cold gas sulfur recovery systems which currently advertise heat recovery. Current fast developing sulfur removal and recovery schemes like zinc ferrite, zinc titanite, and copper based hot gas cleanup systems are expected to be an integral part of the low cost IGCC system contemplated herein.

\section{Summary Table}

\section{Gasifier Attributes}

Gasifier Type

$\begin{array}{cccc}\begin{array}{c}\text { Entrained } \\ \text { Bed }\end{array} & \begin{array}{c}\text { Fluidized } \\ \text { Bed }\end{array} & \begin{array}{c}\text { Fixed } \\ \text { Bed }\end{array} & \begin{array}{c}\text { Pyrolysis } \\ \text { Gasification } \\ \text { (PyGas) }\end{array} \\ \text { (Slag Tap) } & \text { (Dry Ash) } & \text { (Dry Ash) } & \text { (Dry Ash) }\end{array}$

Potential Constraints

(* Denotes Major Area of Impact)

*Caking Coals E

*Ash Fusion Range (Reducing) $\quad \mathrm{P}$

*Tar Production

E

*Volatilized Alkali

*Air Blown Limitations

*Surge Margin Linuitations

Fines Carry-over

E $\quad F$

F

F

E

Exit Temperature

Carbon Utilization

Thermal-Phoresis

$\mathrm{P}$

$P$

G

$\mathrm{E}$

$G$

F

E

$P$

G

E

$P$

E

\section{E}

G

E

E

E

F

E

E P

$P$

E

P

E

F

$\mathrm{P}$

E

E $P$

E G

G

E

Ammonia \& Cyanide Production

G

G

$\mathrm{P}$

E

Pressure Containment

Coal Feed System Losses

G

E

E

F

G

$P$

E

Capacity

Turndown

Key: $\quad$ E - Excellent

$$
\begin{aligned}
& \text { G - Good } \\
& \text { F - Fair } \\
& \text { P - Poor }
\end{aligned}
$$

The above judgements were made on the basis of the entire range of coal characteristics established for consideration in this project. 


\section{Summary Table}

\section{Gasifier Attributes}

Gasifier Type

$\begin{array}{cccc}\begin{array}{c}\text { Entrained } \\ \text { Bed }\end{array} & \begin{array}{c}\text { Fluidized } \\ \text { Bed }\end{array} & \begin{array}{c}\text { Fixed } \\ \text { Bed }\end{array} & \begin{array}{c}\text { Pyrolysis } \\ \text { Gasification } \\ \text { (PyGas) }\end{array} \\ \text { (Slag Tap) } & \text { (Dry Ash) } & \text { (Dry Ash) } & \text { (Dry Ash) }\end{array}$

Potential Constraints

(* Denotes Major Area of Impact)

*Caking Coals

E

*Ash Fusion Range (Reducing)

P

*Tar Production

E

*Volatilized Alkali

* Air Blown Limitations

$\mathbf{P}$

$\mathbf{P}$

E

E

Fines Carry-over

Exit Temperature

Carbon Utilization

Thermal-Phoresis

Ammonia \& Cyanide Production

P

E

E

G

Pressure Containment

G

Coal Feed System Losses

E

Capacity

Turndown

E

F

F
P
G
$\mathbf{P}$
$\mathbf{E}$
$\mathbf{E}$
$\mathbf{P}$
$\mathbf{F}$
$\mathbf{P}$
$\mathbf{G}$
$\mathbf{G}$
$\mathbf{G}$
$\mathbf{P}$
$\mathbf{P}$
$\mathbf{F}$

F

E

G E

F E

G E

G E

F E

P $\quad E$

P E

G E

P $\quad \mathbf{E}$

P E

E G

P E

F G

Key: E- Excellent

The above judgements were made on the basis of

G - Good the entire range of coal characteristics

F - Fair

established for consideration in this project.

P - Poor 


\title{
Status of Low BTU Gasification Systems for a Standardized IGCC Gasifier
}

\author{
Section 1 \\ January, 1991
}

Work Performed Under Contract No. DE-AC21-89MC26291

For

U.S. Department of Energy

Office of Fossil Energy

Morgantown Energy Technology Center

P.O. Box 880

Morgantown, West Virginia 26507-0880

B y

CRS SIRRINE, INC.

Power Division

P.O. Box 5456

1041 East Butler Road

Greenville, South Carolina 29606-5456 


\subsection{Summary}

This section includes the assimilation of empirical data and industry experience describing rixed bed gasifiers as a basis for assessing the status of such gasifiers in IGCC systems.

The standardized IGCC gasifier module is to be compatible with three sizes of coal plants, $50 \mathrm{MW}(\mathrm{e}), 100 \mathrm{MW}(\mathrm{e})$, and $200 \mathrm{MW}(\mathrm{e})$. It is to be operated so as to produce hot raw gas intended for hot gas cleanup and direct combustion in a gas turbine without quenching the gas.

Historical information reveals that maximum coal inputs (hence raw gas outputs) to fixed bed systems vary significantly due to wide ranges in coal reactivity, caking and ash fusion characteristics. Gasification outputs appear to be reduced to less than $50 \%$ of rated capacity when operating on highly caking and low fusion coals. Gas compositions vary with coal composition as would be expected. However, gas composition also varies greatly based upon steam use rates which are governed by ash fusion temperatures and in some cases, grate cooling requirements.

In attempting to understand fixed bed gasifier performance, several gasifier concepts currently at, or near commercially developed, were evaluated. Available gasifier options considered include entrained bed, fixed bed slagging gasifiers, fixed bed nonslagging gasifiers, and a steam fluidized bed gasifier. These were evaluated against desired IGCC criteria with the result that no available gasifier completely meets all the criteria. The Lurgi Mark IV fixed bed non-slagging bed gasifier comes closest to meeting all of the governing criteria.

The typical scope of supply and historical roles of various suppliers with respect to the fixed bed gasifier are also reviewed in this section of the report. 


\subsection{Gasifier Concepts Overview}

The criteria against which each candidate gasifier was measured is as follows:

- Operates as an Air Blown Gasifier

- Operates on Caking Coals

- Operates on Widely Varying Ash Fusion Ranges

- Operates with Run of Mine Coal (High Fines Content)

- Operates at 600 psia

- Minimizes Tar Production

- Minimizes Volatilized Alkali Production

- Minimizes Ammonia Production

- Maximizes Heating Value at $1200 \mathrm{deg}$ F Exit Temperature

In order to better understand the effects of various parameters upon gasifier performance, an overview of various gasifiers which were subjectively judged "near commercial" for the application under consideration was conducted. The results of that overview are as presented in the following sections.

\subsubsection{Overview Descriptions of Candidate Gasifiers}

\subsubsection{Lurgi Fixed Bed}

Lurgi has significant experience as shown in Table 1 (commercial since 1930), mostly with oxygen blown gasifiers on non-caking coals. The gasifier device (in various diameters) is a single stage mature mechanical design applicable to a limited coal range. It is generally acknowledged that the design requires a stirrer to effectively utilize caking coals. In addition, coal fines [1] (less than $3.2 \mathrm{~mm}, 0.125$ inches) beyond approximately $10 \%$ generally cannot be tolerated in the feed; therefore, fines must be separated from the coal feed and either briquetted or fired elsewhere. Tars which are produced must either be removed or their condensation planned for following the gasifier exit. 


\section{Table 1}

FIXED-BED GASIFICATION COMMERCIALLY PROVEN

O LURGI GASIFIERS (Based on O2 Operation):

MARK IV 650 T/D 4 METER DIAMETER

MARK V 1000 T/D 5 METER DIAMETER

O SASOL I - 16 MARK IV GASIFIERS FOR OVER 30 YEARS

O MARK V GASIFIER INSTALLED AT SASOL I - 1979

O SASOL II - 36 MARK IV GASIFIERS - 1979

O SASOL II - 40 MARK IV GASIFIERS - 1982

O SASOL III - TWIN TO SASOL II PLANT - 1982

O GREAT PLAINS GASIFICATION PLANT - 14 MARK IV

O SASOL GASIFIERS - 2 YEAR MAINTENANCE SCHEDULE WITH 3-AND 6-MONTH INSPECTIONS

\subsubsection{British Gas/Lurgi (BGL)}

The BGL approach to solve the above-referenced Lurgi limitations is to inject coal fines and tar through lower bed tuyeres and to operate as a slagging gasifier. In the late 1970's a six (6) ft diameter oxygen blown slagging gasifier was tested on Pittsburgh \#8 coal with $25 \%$ fines without adverse effects on gas quality. 
One distinct advantage of all slagging gasifiers is their benign bottom ash. Concurrently, this slagging approach results in nearly $100 \%$ carbon utilization. Preheated air is required to $1,000 \mathrm{~F}$ to maintain a slag pool.

Indications are that BGL has experience with the Lurgi stirrer [2], and that they successfully gasified Pittsburgh \#8, Ohio \#9, and British coals of equivalent strong caking tendencies with the stirrer. BGL claims to be able to start up from an empty state to full gas production in 4 hours. The device is a single stage mature mechanical design for a wide coal range up to $\mathrm{FSI}=8$ and $25 \%$ fines (below $1 / 4$ inch) provided a deep bed stirrer is incorporated.

\subsubsection{Lurgi Fluidized Bed}

The Lurgi fluidized bed coal gasifier [3] is the result of Lurgi's desire to handle a wide variety of coals. As a higher exhaust temperature fluidized bed, it is likely to produce significant volatilized alkali. Lurgi's current focus is toward this unit as opposed to the fixed bed configuration based upon its ability to handle a wider range of coals and coal fines.

\subsubsection{Dow}

Dow startup occurred in April, 1987 for a 2,200 TPD entrained bed two-stage oxygen blown gasifier [4]. The initial stage is a slagging gasifier which utilizes a ground coal slurry and operates at 2,400F. The second stage admits additional coal slurry to boost the heating value of the gas to approximately $200 \mathrm{BTU} / \mathrm{cu} . \mathrm{ft}$.

This gasifier is NOT AIR BLOWN. All of Dow's experience has been based on oxygen. Private indicators are that the Dow technology may be approaching near commercial basis for air blowing, but only as a licensed product with no process guarantees.

In the Dow demonstration unit, they have provided a $100 \%$ standby gasifier, and report a plant availability of $50 \%$ overall. Their most recent availability is $80 \%$ over a three month period. 


\subsubsection{Shell Coal Gasification (SCG)}

The Shell coal gasifier [5] is NOT A FIXED BED type. In addition, it is NOT AIR BLOWN; however, it is a commercial system.

Shell appears unprepared to guarantee or even offer their gasifier on a commercial basis [5] until their Netherlands demonstration project is complete. Their oxygen blown 2000 TPD 250 MW Netherlands facility will begin operation at the end of 1993.

In their system pulverized coal is dried to $2 \%$ moisture, pressurized to $430 \mathrm{psig}$, and fed into the lower part of an empty vessel with oxygen and steam. The entrained-bed flame temperature reaches $3,000 \mathrm{~F}$, but the outlet from the gasifier is normally $2,700 \mathrm{~F}$. The bottom ash is removed as slag. Fly ash is removed downstream of heat recovery in dry form.

\subsubsection{Texaco}

The Texaco coal gasifier [6] is NOT A FIXED BED type. In addition, it is NOT AIR BLOWN; however, it is a commercial system. Based upon this review, it does not appear that significant test experience exists in an air blown mode.

\subsubsection{MBG Coal Gasification}

The MANGHH coal gasifier [7] is NEITHER A FIXED BED NOR AIR BLOWN. However, as it reportedly is a near commercial device which is to be furnished on a guaranteed performance basis, it shall be included in any overview and pursued as a candidate CRS Sirrine Engineers, Inc. gasifier.

It is anticipated that this device will operate on all US bituminous and subbituminous coals regardless of caking properties, and regardless of fines content since the coal feed is in pulverized form. Therefore it has the potential for much wider applicability than currently commercial fixed bed air blown gasifiers.

Its product gas, at $312 \mathrm{BTU} / \mathrm{scf}\left(51 \% \mathrm{H}_{2}, 11 \% \mathrm{CH} 4\right)$, may not require any significant combustor modifications to be acceptable to current gas turbine. combustion systems. 
Because it operates at $1500 \mathrm{~F}$, tar condensation is not likely to be an issue, therefore it may solve three major fixed bed gasifier limitations, (i.e., caking coals, fines, and tar).

\subsubsection{Process Descriptions of Candidate Gasifiers}

\subsubsection{Lurgi Fixed Bed}

The process consists of high pressure coal gasification in a gravitating bed by injection of steam plus air (or steam plus oxygen) with countercurrent gas/solid flow. Sized coal (1 1/2 inch $\times 1 / 4$ inch) is fed through a lock hopper arrangement into the top of the gasifier. The resulting ! Jw BTU gas (100-180 BTU/std cu ft) is normally water quenched to avoid tar, oils, phenols, ammonia, and particulate contamination of the combustible produced gas (Table 2).

- Gasifier dimensions:

\section{LURGI GASIFIER CHARACTERISTICS}

-2.5 to $3.8 \mathrm{~m}(8.3$ to $12.4 \mathrm{ft})$ in diameter

-2.1 to $3.0 \mathrm{~m}$ (7 to $10 \mathrm{ft}$ ) coal bed depth

$-5.8 \mathrm{~m}$ (19 ft) approximate overall height of coal gasifier itself

- $12.5 \mathrm{~m}$ (41 ft) height flange to flange including coal and ash locks

- Bed type and gas flow: gravitating bed; continuous countercurrent gas flow; lateral gas outlet near the top of the gasifier.

- Heat transfer and cooling mechanism: Direct gas/solid heat transfer, water jacket provides gasifier cooling.

- Coal feeding mechanism: Intermittent, pressurized lock hopper at the top of the gasifier which dumps the coal onto a rotating, water-cooled coal distributor.

- Gasification media introduction: Continuous injection of steam plus air or oxygen at the bottom of the coal bed through a slotted ash extraction grate.

- Ash removal mechanism: Rotating, slotted grate at the bottom of the coal bed; refractory lined, pressurized lock hopper collects the ash and dumps it intermittently.

- Turndown to approximately $50 \%$ acheivable. 
- Special Features:

- Direct quench gas scrubber and cooler which knocks out particulates, tars, oils, phenols and ammonia is attached to the gasifier at the gas outlet.

- Gasifier water jacket supplies approximately 10 percent of the required gasification steam.

- Rotating distributor provides uniform coal bed depth.

- Tar injection nozzle at the top of the gasifier permits recycle of by-product tar which also helps to reduce coal fines carryover in the product gas (optional feature).

- Rotating, optional water cooled coal bed agitator aids the gasification of strongly caking coals.

In the air blown mode, the device is output limited by volume and velocity increase over oxygen blown operation. Preheating of the inlet air to assure gasifier exiting temperature in excess of tar condensation temperatures is limited by the materials of construction of the grate and grate drive.

This design may produce excessive fines carryover and experience clinkering from interstitial fines plugging during devolatilization when caking coals exceed $10 \%$ fines. The expected performance of the gasifier air blown on caking coals is directly related to the Lurgi stirring mechanism capabilities to deal with clinker formation. It is known that the Lurgi stirrer was successfully tested (per DOE) on moderately caking coals at SASOL in a $12 \mathrm{ft}$ diameter gasifier. In general, however, Lurgi requires pre-heating to condition highly caking coals. This is unattractive owing to the added complexity of the system.

Typical Lurgi performance characteristics when air blown at $300-450$ psi are as follows $(8,10)$ :

Input:

Low Caking Coal Flow $=21$ tph typ (10-26.5 Range)

High Caking Coal Flow $=13.8$ tph typ (6.4-16. 4 Range)

Steam Flow $=14$ tph typ $(0.6-1.5 \mathrm{t} / \mathrm{t}$ coal $)$

Air Flow $=44 \mathrm{tph}$ typ $(1.3-3.7 \mathrm{t} / \mathrm{t}$ coal $)$

Outputs:

Proportional to diam sq \& sq rt of opn press

Gas Quality = $150 \mathrm{BTU} / \mathrm{scf}(100-180 \mathrm{BTU} / \mathrm{scf})$

Gas Flow $=79$ tph typ (3.75 $\mathrm{t}$ gas/t coal per METC)

Gas Flow $=47$ MMscfd

$\mathrm{H} 2 \mathrm{~S}=0.78$ tph typ

Tar $=6$ tph typ

Ash $=5$ tph typ

Ammonia (NH3) $=4000-9000$ ppmv (METC)

Volatilized Sodium $(\mathrm{NaCl})=0.028-0.035 \mathrm{ppmv}$

Volatilized Potassium $(\mathrm{KCl})=0.13-0.16 \mathrm{ppmv}$

Temperature - $955 \mathrm{~F}$ typ

Ash Carryover $=0.96$ tph typ $(3.7 \%)$ 
Areas of Technical Concern Include:

- Coal Fines: Must be removed

- Caking Coals: Some stirrer experience; little mfg confidence

- Tar Production: Expect about 5\%, maintain above condensation temp

- Ammonia Production: Approximately $0.5 \%$ producing $\mathrm{NO}_{\mathrm{x}}$ at $3000 \mathrm{ppm}$

- Volatilized Alkali: Little expected @ 1000 F-1100'F exit temp

- Carbon Utilization: Expect 3-10\% carbon carryover

- Coal Input per Unit: Limited by coal properties to 6-26 tph.

It is understood that the Lurgi fixed bed gasifier pressurized lock hopper arrangement has an associated thermal loss from gasifier hot gas product venting. Such venting is necessitated by the admittance of hot raw gas product during the coal feed sequence. This hot raw gas is at operating pressure and hence must be vented before the coal bunker side valve is opened to atmosphere. Depending upon where and how the gas is vented, it can be a significant loss to the process.

\subsubsection{British Gas/Lurgi (BGL)}

The British Gas Lurgi (BGL) oxygen blown system was estimated by EPRI to cost $22 \%$ less than Lurgi in 1976 [3]. The BGL design utilizes highly preheated oxygen consistent with tap port temperatures which will both maintain molten slag and assure all recycled organic species are burned to extinction, thereby eliminating concerns over sulfur bearing oil and tar compounds. Since BGL is a slagging type gasifier, it is claimed to be capable of handling all US coals.

The BGL design provides for very high operating temperatures in the slag tap (and hence char burning) area which increases its output capacity. The negative aspect of this feature may be a greater propensity. for volatilized sodium leaving the gasifier. The quenched slag is easily handled and "environmentally benign" per DOE.

The BGL gasifier unit has a good history of feeding a coal fines/water slurry directly into the grate tuyere area without output degradation.

Typical BGL results for their $71 / 2 \mathrm{ft}$ dia.unit are as follows:

- Various Coals Including Pittsburgh, \#8 Coal, $11 / 4$ in $\times 1 / 8$ in size, FSI 7.5

- Rated Coal Input = 21 tph (Equiv Coal Input @ $12.63 \mathrm{ft}$ ID=60 TPH)

- Maximum Achieved Unit Power Output =27 MW (Equiv. Unit Pwr Out =75 MW)

- Steam/Oxygen $=0.6-0.9 \mathrm{t} / \mathrm{t}$ coal

- Steam Consumption $=0.3-0.5 \mathrm{t} / \mathrm{t} \mathrm{coal}$

- Oxygen Comsumption $=0.5-0.6 \mathrm{t} / \mathrm{t}$ coal

- Output Gas = 298 - 357 BTU/scf

- Water Quenched Ash 
Areas of Technical Concern for the BGL unit are as follows:

- May freeze tap port on high fusion coal when air blown

- Coal fines carryover: must be collected and reinjected into hot zone

- Caking Coals: Only short term $\mathrm{O}_{2}$ blown experience

- Est. Volatilized Sodium $(\mathrm{NaCl})=0.028-0.035$ ppmv (perhaps higher)

- Est. Volatilized Potassium $(\mathrm{KCl})=0.13-0.16 \mathrm{ppmv}$ (perhaps higher)

\subsubsection{Lurgi Fluidized Bed}

Lurgi CFB gasification units can be air or oxygen operated. Like the fixed bed processes the CFB can be operated at atmospheric or elevated pressures. The latter is, however, still in the demonstration phase and is available on limited commercial terms.

The advantages associated with the CFB gasifier are as follows:

- Intensive mixing of gas and solids

- High heat and mass transfer rates

- High gasification reaction rates (i.e. high specific throughput)

- Uniform temperature through the reactor (no hot spots)

- Zero tar and oil production

- Insitu desulfurization by limestone addition

The gasification unit comprises the cylindrical, refractory lined reactor and the cyclone for the recycling of solids.

Feed material enters the reactor by means of a screw feeder, located at the reactor's base. Preheated gasification agent is injected into the reactor bottom.

For coals it is sufficient in most cases to crush it to about minus $6 \mathrm{~mm}$.

Expected CFB performance is as follows:

- Coal Throughput=51 TPH (O2 Blown) @ $13 \mathrm{ft}$ dia \& 300 psig

- Gas Quality = 117 B'TU/scf (typ air blown)

Areas of Technical Concern for the CFB gasifier are as follows:

- Coal Fines: Not a problem

- Caking Coals: Not a problem

- Tar Production: Not a problem

- Ammonia Production [3]: 8 - 20000 ppmv > Significant NOx Likely on Coal

- Volatilized Sodium [8] $(\mathrm{NaCl})=0.8-23 \mathrm{ppmv}$

- Volatilized Potassium [8] $(\mathrm{KCl})=2-12 \mathrm{ppmv}$

- Carbon Loss [3]: High; 65\% carbon in dust is also significantly high 


\subsubsection{Dow Gasifier}

The Dow gasifier is an oxygen blown entrained bed concept originally developed by Dow to produce synthetic gas for subsequent chemical processing. The system was, according to Dow discussion, optimized to utilize lignite as the source of gaseous chemical feedstocks.

The Dow unit is sized for a nominal coal input of 95 tons per hour. The areas of technical significance for this unit are as follows:

- Coal fines: Compatible since primary fuel is crushed to less than $1 / 8$ inch.

- Caking coals: Compatible since the fuel stream is a ground coal slurry (process not yet demonstrated on highly caking coals)

- Tar Production: Minimal due to high exhaust temps

- Ammonia Production: Minimal due to high exhaust temps

- Volatilized Alkali: Significant due to high temperatures

- Carbon Utilization: Excellent due to recycle and slagging operation

\subsubsection{Shell Gasifier}

The Shell gasifier represents one of the most commercially advanced coal gasifiers and is therefore discussed in greater detail here. According to published information, the Shell Coal Gasification Process (SCUP), is a clean and efficient process for converting coal into fuel gas. It is based on a dry feed, entrained-bed, high-pressure, high temperature slagging design. The process can handle a wide variety of coals, ranging from bituminous to lignite, in an environmentally acceptable way and produces a high purity medium-BTU gas.

Much of the equipment and the expertise required to operate the equipment in the process is widely utilized in other applications both within the utility industry and the petroleum refining/petrochemical industries. Examples include coal receiving, milling and drying, and dry pneumatic coal conveying systems which are very much related to existing utility central station generating facilities. The gasification process is not unlike that of utility coal Cyclone (B\&W) and wet bottom Turbofurnace (Riley) applications in that coal is consumed at high temperature and its inorganic fraction is removed from the furnace in molten slag form. Acid gas removal and recovery using the Sulfinol system may be likened to existing petrochemical acid recovery and production processes such as Claus or Stretford, 
except that apparently Sulfinol is a physical/chemical solvent absorption system unlike Stretford which is a direct oxidation system.

The coal receiving and handling facilities utilized in an SCGP plant are conventional and similar to those already being utilized in many existing coal fired boiler installations. Unloading hoppers, vibrating feeders, conveyors, stackers, and reclaimers well proven at existing coal burning facilities can be readily employed in the SCGP plant.

The coal milling drying unit includes a conventional bowl mill, identical to those used in a fulverized coal boiler. This mill grinds the coal to a specification of 90 wt\% less than 88 microns with a maximum of 5 wt\% less than 5 microns. As the coal is being ground, it is simultaneously dried to $5 \mathrm{wt} \%$ moisture content, utilizing a steam heated inert gas stream that carries the evaporated water from the system as it sweeps the pulverized coal through an internal classifier to collection in a baghouse. By-product nitrogen from the air separation plant is used as makeup inert gas for the drying operation. The dried and milled coal is delivered to the gasifier feed system using a pneumatic conveying system.

A 95\% (volume) oxygen stream is supplied by an air separation plant and compressed for delivery to the gasification plant.

Nitrogen from the air separation unit is compressed to provide low pressure and high pressure nitrogen for use in the gasification plant, for makeup inert gas to coal milling and drying, and for transporting coal in the feed system.

Milled and dried coal from the coal milling and drying area is pneumatically transported to the coal pressurization and feeding system. This system consists of a receiving vessel, two lockhoppers, and a feed hopper. The receiving vessel separates the coal from its nitrogen transport medium and then transfers the coal to one of the two lockhoppers. These two lockhoppers are operated on a time cycle such that one is filled and pressurized while the other is emptied and depressurized. Once a lockhopper has been charged with coal from the receiving vessel, it is then pressurized with nitrogen and its contents discharged into the feed hopper. Pressurized coal is continuously withdrawn from the feed hopper and pneumatically conveyed with nitrogen to the gasifier's coal burners. 
The nitrogen which is separated from the incoming coal in the receiving vessel is recycled to the milling and drying system through bag filters located in the receiving vessel.

Lockhoppers are widely utilized in materials handling applications. They have proven to be a safe and reliable method for transferring solids under pressure.

In the gasifier, pressurized coal, oxygen and, if necessary, steam enter the pressure vessel through opposed burners. The gasifier consists of an outer pressure vessel and an inner, water-cooled membrane wall. The gasifier wall temperature is controlled by circulating water through the membrane wall to generate saturated steam for subsequent superheating in the syngas cooler. The membrane wall encloses the gasification zone from which two outlets are provided. One opening at the bottom of the gasifier is used for the removal of slag. The other opening allows hot raw gas to exit from the top of the gasifier.

Most of the mineral content of the feed coal leaves the gasification zone in the form of molten slag. The high gasifier temperature (up to $3000^{\circ} \mathrm{F}$ ) ensures that the molten slag flows freely down the membrane wall into a water-filled compartment at the bottom of the gasifier. Flux may be added to the coal feed to promote the necessary slag flow out of the bottom of the gasifier if the ash viscosity of a particular coal would not generate the proper slag flow from the gasifier. As the molten slag contacts the water bath, the slag solidifies into dense, glassy granules. These slag granules fall into a collecting vessel located beneath the slag bath and are transferred to a pair of lockhoppers which operate on a timed cycle to receive the slag. After a lockhopper is filled, the slag is washed with clean makeup water to remove entrained gas and any surface impurities. After washing, the lockhopper is depressurized and the slag is fed to a dewatering bin. This bin is equipped with an inclined screw to lift the settled solids off the bottom of the vessel and deposit them on a conveyor belt for delivery to intermediate storage.

The hot raw product gas leaving the gasification zone is quenched with cooled, recycle product gas to convert any entrained molten slag to a hardened solid material called flyslag prior to entering the syngas cooler.The syngas cooler recovers highlevel heat from the quenched raw gas by generating superheated high-pressure steam. The syngas cooler includes superheat, evaporative, and economizer 
sections. The gasifier and syngas cooler included in the SCGP plant are similar to the water wall boilers which are widely used in other utility processes.

The bulk of the flyslag contained in the raw gas leaving the syngas cooler is removed from the gas using commercially demonstrated equipment such as bag filters or cyclones. The remainder of the solids is washed out in a series of scrubbers (9) and separators. The gas leaving the scrubbers has solids content of 1 $\mathrm{mg} / \mathrm{m} 3$ and a temperature of 40 degrees $\mathrm{C}$. If not recycled, the flyslag leaving the process is pneumatically conveyed to one of two flyslag lockhoppers. After a lockhopper is filled, the flyslag is purged with high pressure nitrogen to remove any entrained raw gas. After purging, the lockhopper is depressurized and the flyslag is pneumatically conveyed to a silo for intermediate storage. All vent gases from the flyslag lockhoppers and the storage silo are filtered of particulates during discharge.

The gas leaving the bag filters is further purified by passing through a wet particulate removal unit where any residual flyslag is removed to a level of less than $1 \mathrm{ppm}$. This wet scrubbing system also removes other minor contaminants such as soluble alkali salts. Makeup water is continually added to the wet particulate removal unit to control the concentration of contaminants in the blowdown stream. The contaminated water is sent to the sour water stripping unit to recover the contaminants.

The washed raw gas from the wet particulate removal unit is routed to a catalytic hydrolyzer to convert the minor nitrogen contaminant (hydrogen cyanide) to ammonia, and carbonyl sulfide (COS) to hydrogen sulfide. The gas is heated before entering the hydrolyzer to the appropriate conversion temperature using medium pressure steam. Gas leaving the hydrolyzer is cooled by heat exchange with process makeup water, product gas, boiler feedwater, and/or cooling water.

The last treatment the medium BTU gas receives before it is delivered to the power block is contact with an aqueous MDEA (methyl diethanolamine) solvent to remove hydrogen sulfide in an acid gas absorber. In this absorber, the hydrogen sulfide in the raw fuel gas is absorbed by countercurrent contact with the MDEA solution. Clean medium BTU gas containing about 100 ppmv hydrogen sulfide plus carbonyl sulfide leaves the absorber. This sulfur level is well below that required by current air emission standards for combustion of the fuel gas in the combustion turbines. 
A typical composition of the clean medium BTU gas now ready for delivery to the combustion turbines is shown on Table 3.

\section{Table 3 Shell Gasifier Output Composition}

Component

$\mathrm{H} 2$

$\mathrm{CO}$

$\mathrm{CO} 2$

$\mathrm{H} 2 \mathrm{~S}$

COS

$\mathrm{NH} 3$

$\mathrm{CH} 4$

N2

$\mathrm{Ar}$

$\mathrm{H} 2 \mathrm{O}$

LHV, BTU/lb

LHV, BTU/scf
Percent Volume

32

62

1

$26 \mathrm{ppm}$

$77 \mathrm{ppm}$

$2 \mathrm{ppm}$

0.03

4

0.50

0.20

5,465

288

\subsubsection{Texaco Gasifiers}

One of the most widely utilized coal gasification concepts is the oxygen blown Texaco process. As with the Shell concept presented previously, this widespread acceptance gives it a certain "near commercial" credence which justifies a more thorough review. 
The Texaco process is an entrained bed oxygen blown system capable of burning a wide variety of coal sizes and types. This process includes a pulverized coal/water slurry which is introduced at 600 psig into the top of a refractory lined vessel using a specially designed burner. It is mixed with oxygen to produce a partial combustion gas at $2,300-2,800^{\circ} \mathrm{F}$ temperatures. Medium BTU gas results and the ash is removed as molten slag from a slag tap port in the bottom of the radiant cooler below the gasifier reactor vessel.

The hot coal gas and slag from the gasifier reactor discharge into the radiant cooler below which generates 1,600 psig saturated steam. The slag drops into a water pool at the bottom of the radiant cooler and is removed through a lock hopper system. The process proceeds into a convection cooler where more $1,600 \mathrm{psig}$ saturated steam is generated.

The technical issues associated with the Texaco gasifiers are as follows:

- Coal Fines: Good compatibility, but some fines may carry over and be recycled back into the gasifier.

- Caking Coals: Compatible

- Tar Production: Free of tars and phenols

- Volatilized Sodium $(\mathrm{NaCl})=8-46 \mathrm{ppmv}$

- Volatilized Potassium $(\mathrm{KCl})=4-1000 \mathrm{ppmv}$

- Carbon Utilization: Excellent

- Coal Input per Unit: 42 tph (15 TPH @ Ube)

Characteristics of the Texaco process are as shown in Table 4. 
Characteristic

Experience
Complexity
Capacity
Inventory (coal)

Feed Coal

Type Handling

Product Gas
Ash Removal
Produces inert slagged ash with low carbon content; fines carried over can be recycle to gasifier.

Temperature

Operating Range

\section{Advantage}

Commercial design available and development program exists on second-generation processes.

No moving parts and has simpler geometry than fluid bed. Water jackets add to system complexity.

Highest capacity per unit volume

Any coal may be used without pretreatment. No fines are rejected.

Free of tars and phenols.

\section{Table 4}

\section{Texaco Gasifier Characteristics}

Limitation

Less developed than fixed bed

Critical design areas include combustor nozzles and heat recovery in presence of molten slag.

Smallest inventory of four generic classes: requires advanced control techniques to ensure safe reliable operation.

Pulverizing and drying of surface moisture are required. Potential erosion due to gas-solid streams.

Ash, char, and sensible heat in gas must be recovered, which reduces efficiency.

Higher thermal loss in ash.

Highest temperature of four classes (1) causes thermal losses, (2) requires better materials of construction, and (3) requires greater use of oxygen or preheated air which results in higher $\mathrm{CO}_{2}$ content in product gas.

Process has the least operating range and is limited by need to maintain slagging conditions without degrading refractories.

With regard to operating experience, Cool Water, the best known of the Texaco gasifiers, is one of four full-scale Texaco Coal Gasification plants in commercial operation today.

In a second Texaco project, Tennessee Eastman, a subsidiary of Eastman Kodak, has operated a 900 TPD gasifier at Kingsport, Tennessee since 1983, producing methanol and acetic anhydride. That unit has an onstream factor of greater than 90 percent. 
In a third project, Ube Ammonica Industry Co., Inc. owns and operates a 1,650 TPD Texaco gasification plant in Japan for ammonia production. The facility began operations 1984 and has been onstream over 90 percent of the time since startup. Ube has run on petroleum coke and has gasified a variety of coals, including some from South Africa, Australia, and Canada.

The fourth project is Synthesegas Anlage Ruhr (SAR). In the summer of 1986, an 800 TPD gasification plant began operations at the SAR plant in Oberhausen, West Germany. SAR produces syngas as a feedstock to make several organic chemicals. Worldwide, over 90 plants have used Texaco gasification to make syngas from various petroleum feedstocks. Many of the key process components in these plants, such as sulfur removal and recovery equipment, are used routinely in oil refineries and other industries.

\subsubsection{MBG Coal Gasification}

The process consists of high pressure coal gasification in a FLUIDIZED bed by injection of steam plus heat from an indirect in-bed heat exchanger. Run of mine coal ( 3 inch $\times 0$ inch) is pulverized and then fed through a pressure raising arrangement into the top of the gasifier. The resulting low BTU gas is normally water quenched to increase the heating value (to $312 \mathrm{BTU} / \mathrm{std} \mathrm{cu} \mathrm{ft}$ ) and to remove ammonia, cyanide, and particulate contamination.

STEAM blown, the device is output limited by volume and velocity increase which tend to carry over pulverized coal in all but the lowest superficial velocities in fluid bed operation. Preheating of the inlet heat exchange medium (helium in one case, and hydrogen regenerator in another) to assure gasifier exiting temperature in excess of tar condensation temperatures is limited by the materials of construction of the heat exchanger.

There is some concem that this design may produce excessive fines carryover and large levels of volatilized alkali.

The expected performance of the steam blown gasifier on caking coals is expected to be unaffected by caking properties since the coal is pulverized, and the bed is fluidized. Although MANGHH has acknowledged having a pilot plant with some 26,600 hours of operation (33\% of which was on caking coals), the system is not available for commercial supply. 
Anticipated gasifier performance is as follows:

Input:

Coal Flow $=15$ tph typ

Superheated Fluidizing Steam $>1000^{\circ} \mathrm{F}$

Operating Pressure $=21 \mathrm{bar}$

Operating Temperature $=1500 \mathrm{~F}(1490-1526 \mathrm{~F})(810-830 \mathrm{C})$

Output:

Gas Quality $=312$ BTU/scf

Tar = Likely to be an issue

Ash $=$ Recycling necessary

Ammonia - Unknown status

Volatilized Sodium - Expected to be high

Temperature $-1500 \mathrm{~F}$ typ

Ash Carryover $=$ Known to require recycle

Areas of Technical Concern are as follows:

- Coal Fines: Carryover may be a problem

- Caking Coals: Compatible

- Tar Production: May be a problem @ 1500F

- Ammonia Production: Unknown

- Volatilized Alkali: High levels; requires subsequent quench

- Carbon Utilization: Estimated @ 95\%

- Others

- Helium media heat exchanger will have materials of construction concerns @ 1500F. This may be acceptable if replacement intervals \& cost are reasonable.

- Undetected failure of in-bed exchanger may cause catasa uphic heat release. 


\subsection{Estimated System Performance}

\subsubsection{Performance Discussion}

Publically available empirical information was used to generate predicted Lurgi Mark IV fixed bed air blown configuration gas generation rates and gas compositions.

A general synopsis of the Lurgi system was recently developed by METC (Notestein) and is repeated here to establish a basis for subsequent performance comments.

According to METC, with the use of the fixed bed gasifier, there has historically been a problem relative to the use of feedstock coal with a "large" fines fraction (defined as the portion of the coal which is less than 0.25 inch in size). With the conventional Lurgi design, this concern arises for two reasons. First, the water quench liquid based gas cleanup system is susceptible to reduced performance, plugging, etc. as a result of excessive dust/fines being carried over in the raw product gas and depositing in the scrubbing liquor. Secondly, the design of the top of the gasifier does little to reduce the propensity for solids carryover (Figure 1) since the top of the coal bed is essentially at the elevation of the cup shaped pan immediately above the "distributor" blades. The blades turn through the upper portions of the coal bed probably within a few feet of the top of the bed (to maintain porosity of the devolatilization zone and break up any forming agglomerates). The raw gas outlet is very near the top of the coal bed and represents a localized port in a region where a significant portion of the gasifier cross section is unavailable for gas flow (due to blockage by the coal feed and distribution machinery). It is consequently probable that, over at least some portion of the bed surface, local gas velocities are actually accelerating as the raw gas leaves the coal bed, passes through the overbed region, and reaches the gasifier outlet to the scrubbing cooler. 


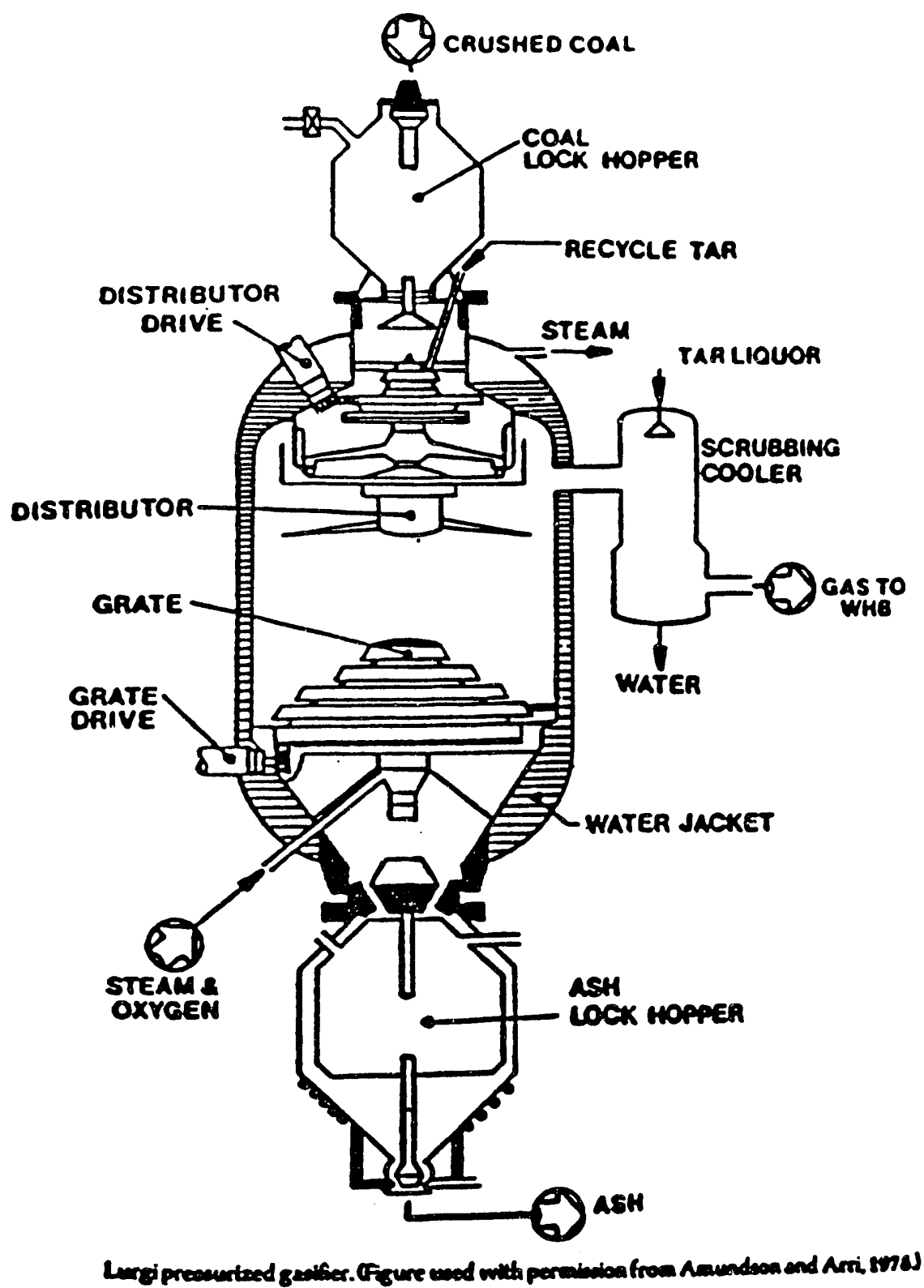

Figure 1

Nowacki, Perry ed. Coal Gasification Processes. Noyes Data Corp.; Park Ridge, New Jersey; 1981. 
As a result, any fines which are picked up by the gas leaving the bed are quite likely to remain entrained with the gas, at least until it enters the scrubbing cooler. This problem has been addressed by Lurgi with two basic approaches; [1] make the coal "sticky" so individual fines are attached to larger non-entrainable lumps and [2] cover the fines quickly so there is a more tortuous pathway to be followed before the "average fine" can exit the coal bed.

An example of the first approach is the use of "recycle tar" which is ejected onto the coal in the distributor to serve as a dust suppressant. Similarly, tests have shown that a higher fraction of fines can be tolerated with "tarry" coals, such as Pittsburgh \#8, which become "sticky" as they warm in the top of the gasifier.

One of the most sophisticated embodiments of the second approach is found in Lurgi's U.S. Patent No. 4,405,340. When coal or any solid is dumped in a pile, it will assume a natural angle of repose characteristic of the particular solid material and will also become segregated with the preponderance of larger particles falling to the outside of the pile and the smaller, or fine, particles residing in the middle of the pile; i..., the motions inherent in the piling process encourage the fines to be located near the centerline of the distributor and the larger particles on the periphery. This patent allows the size segregation to take place within the distributor and positions coal outlet chutes such that "predominantly fine" coal, is laid on top of the bed and immediately overlain by "predominantly coarse" coal exiting from a second distributor discharge chute (as the distributor pan rotates). This is a relatively recent patent (1983) and the degree to which this design has proven to be beneficial is not presently known.

From a gas perspective, the grate design of the Lurgi gasifier tends to emphasize uniform gas distribution and relies primarily on the amount of steam utilized and the chemistry of the coal char/ash to preclude excessive clinker formation. While hardfacing of grate surfaces is done, this appears to mitigate wear and there are no features to overtly deal with clinkers. As alluded to above, if the bed temperature distribution is as designed, the stirrer will reduce the formation of agglomerates in the upper portions of the bed (incipient clinkers) and the steam will suppress lower bed temperatures enough to preclude the formation of significant clinkers. Under 
these conditions there is no need to deal with clinkers; however, this grate design is not very forgiving should clinkering occur.

Beyond this issue of fines (and a separated one of caking coals), it is an acknowledged fact that a Lurgi gasifier will produce a low BTU gas that can be used in a gas turbine. The remaining issues are primarily economic in nature, i.e., the means to dispose of the "dust" caught by the cyclone, and the cost of acquiring and installing the gasifier hardware. Table 5 provides a summary of Pro/Con statements relative to this design.

\section{Table 5 \\ Dry Bottom Lurgi Concept \\ PRO \\ CON}

1. Huge general experience base.

2. Capable of using all U.S. coals. (w/modifications as discussed later)

1. Little experience with air blowing, and none with "non-quenched" operation.

3. Very coal specific capability to accept up to 35 percent of the feed as fines.

2. Grate not tolerant of "rocks".

3. Top bed stirring only.

4. Large steam usage.

4, Commercially availability.

5. Tars and fines in product gas.

6. Internal/central feed system raises over bed gas velocities and complicates stirrer. 


\subsubsection{Performance Parameters}

In the performance of a fixed bed gasifier, the output of the device is a function of:

1) The characteristics of the coal being supplied.

2) The relative quantities of air and steam contained in the blast.

3) The operating pressure.

As shown in Figure 2, the gasifier is roughly divided into "zones" which accomplish the following:

- A drying, tar producing zone at the top of the gasifier.

- A devolatilization zone producing light organic compounds.

- A gasification zone producing the primary gasifier fuel components, $\mathrm{CO}$ and $\mathrm{H}_{2}$.

- A combustion zone producing the heat necessary to drive the reactions in the zones above.

- A bottom ash cooling zone which preheats the incoming air and steam.

Typical gas compositions and temperatures at various locations in a fixed bed gasifier (air blown) are shown in Figure 3, while Figure 4 connotes various operating parameters in a Lurgi gasifier. 


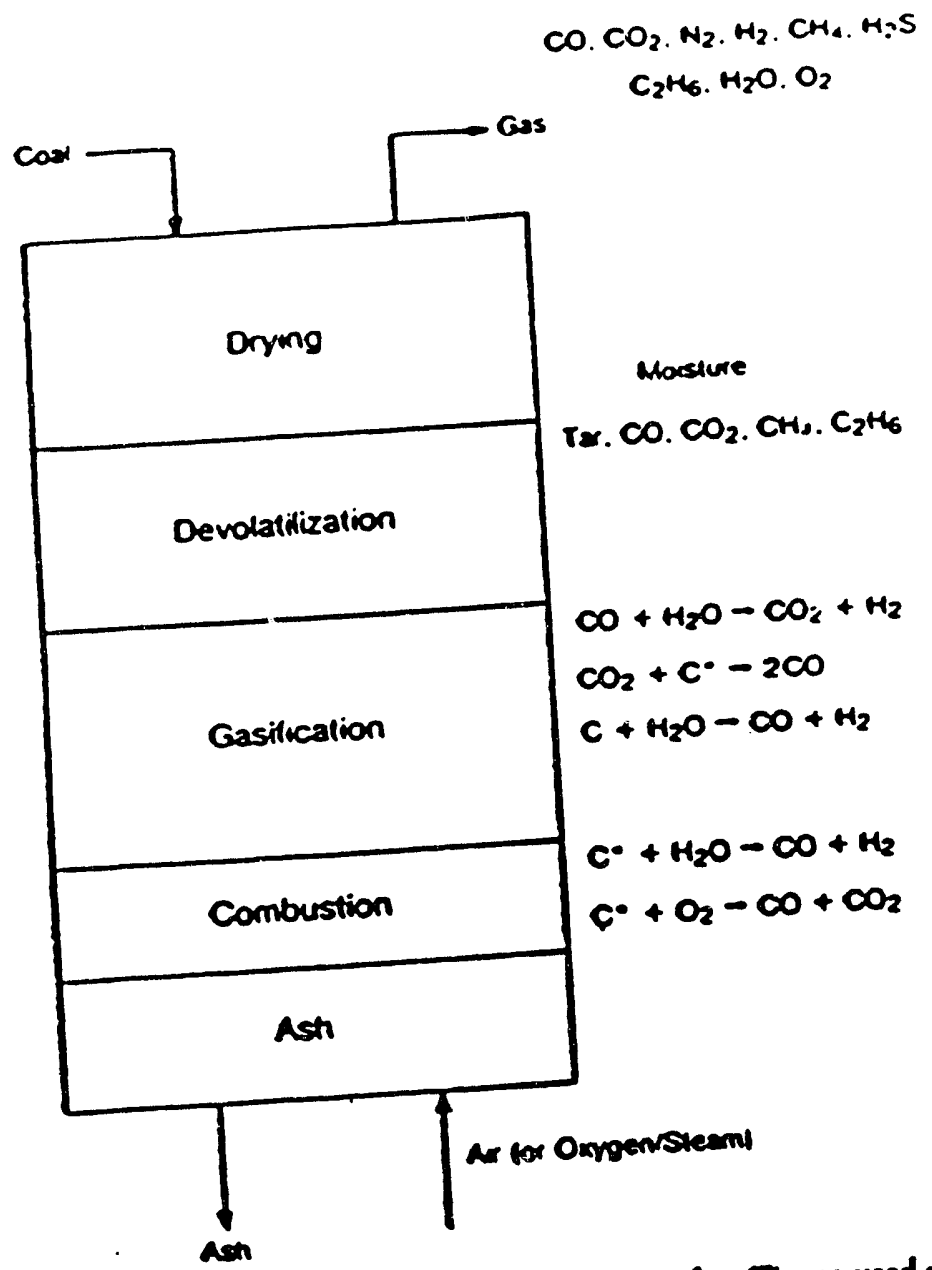

Chemical resctions cocurring on a fixed bed peifier. Finure used with permission from

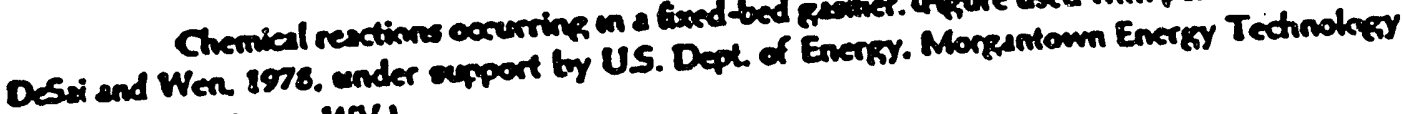
Center. Monganiown. WVI

F1gure 2

25 


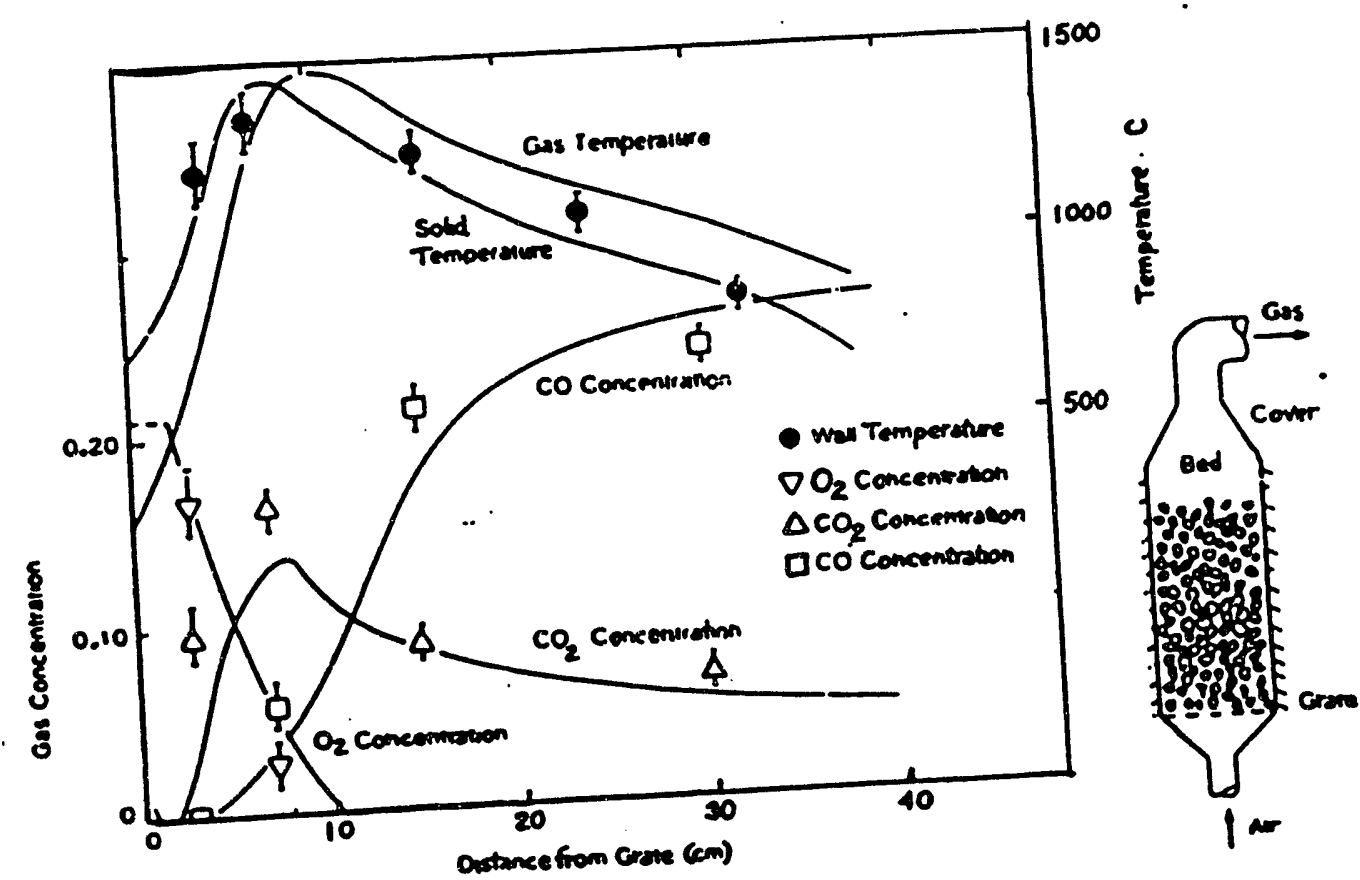

Comparicon of measured and predicted temperature and cuncentication prafiles chrountrout a Gxed-bed gasafier. (Figure used with permienion from Burrapa and Essenhingh. 1979$)$

FIgure 3 


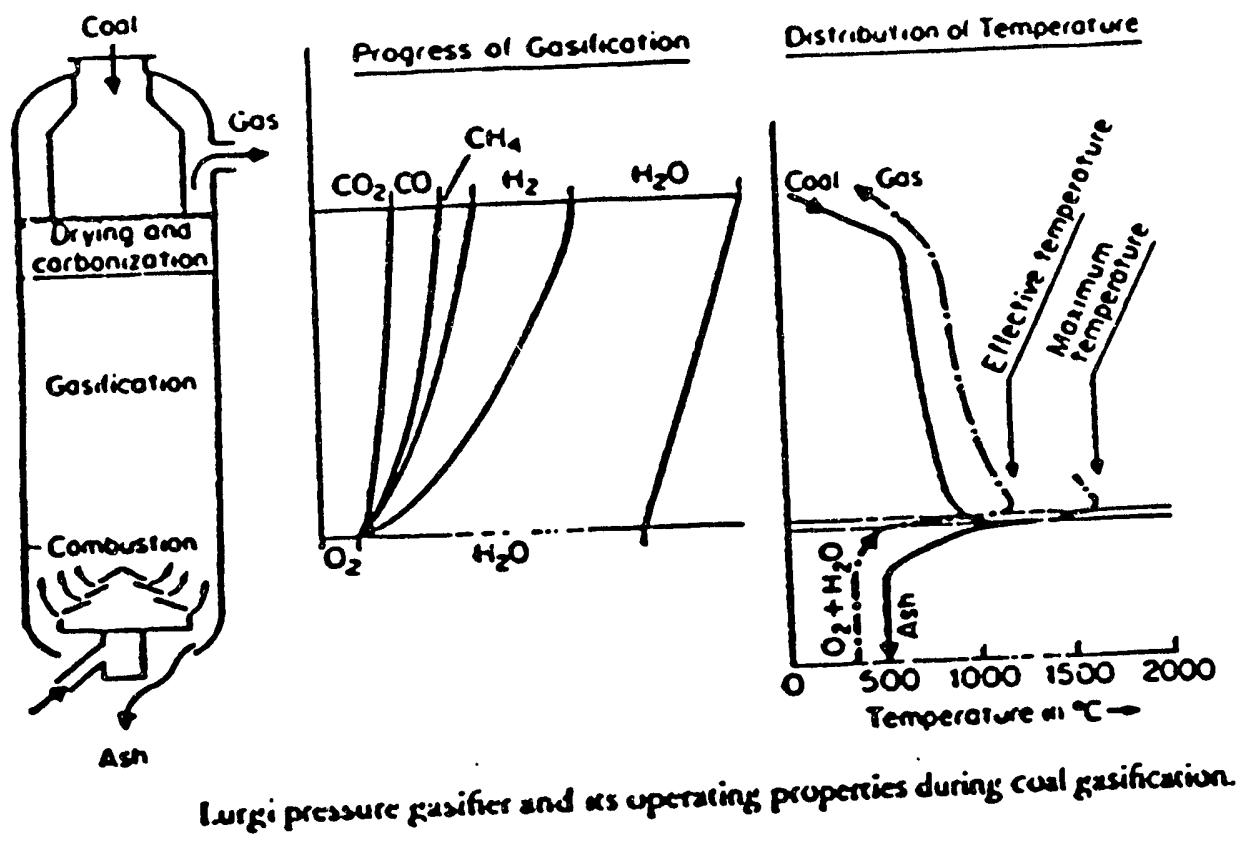

Figure 4 
The performance of the Lurgi gasifier is, as stated previously, determined by the coal characteristics and the air and stean quantities involved. From a simplified analysis, these factors manifest themselves as follows:

a) The coal provides the carbon and tyydrogen for the resultant $\mathrm{CO}, \mathrm{CxHy}$, and $\mathrm{H}_{2}$ in the resulting gas.

b) The coal provides the carbon and hydrogen required in the combustion which elevates the reactants to the desired temperature level.

c) The air quantity provides the oxygen required by the combustion (b above) and the $\mathrm{CO}$ in the gases.

d) The steam quantity provides the tempering effects on bed temperature to maintain levels below ash fusion temperatures.

Utilizing these performance indicators yields the range of input/output parameters as shown in Table 6.

\section{Table 6 \\ Estimated Lurgi Air Blown Characteristics}

1. Gas Outlet Temperature: 700 to $1100^{\circ} \mathrm{F}$

2. Gasifier Pressure: 300 to 465 psia

3. Solids Residence Time: Approximately 1 hour

4. Coal Feed Rate: 100 to $400 \mathrm{lb} / \mathrm{hr}-\mathrm{ft} 2$

5. Coal Sizing: Up to 1.5 to 2.0 inches with up to $10 \%$ less than 0.125 inches

6. Steam Input: Approximately 0.5 to $0.6 \mathrm{lb}$ per $\mathrm{lb}$ of coal.

7. Air Input: 1.3 to $2.0 \mathrm{lb}$ per lb of coal

8. Gas Production: 13 to 67 scf per lb coal 
Using the Mark IV dimensions of 12.4 feet in diameter and 10-12 feet of active coal depth, the solids bed moves downward at approximately 0.2 feet per minute, and the coal input is approximately 6 to 24 tons per hour. At 12,000 3TU/1bm HHV, the gas production would be approximately 1.5 to $5.5 \mathrm{~mm}$ BTU per hour.

Tables 7 thru 12 show the performance of air-blown, fixed-bed gasifiers as presented in various published reports.

In addition to these published data, METC has generated data on fixed bed gasifier output which indicates that output is related to absolute pressure to the 0.5 power. Figure 5 illustrates the results of this pressure effect.

As a general overview of the status of air-blown, fixed-bed gasifiers, Table 13 summarizes much of the available data while Figure 6 illustrates the results.

A key element in the performance of the standardized IGCC gasifier is the expected alkali metal output. Figures 7 and 8 illustrate those expected performance parameters based upon available data.

\subsection{Issues Affecting Gasifier Performance}

Based upon a review of available information as presented in Sections 1 thru 3 of this report, it is anticipated that the parameters listed in the following paragraphs will affect air-blown, fixed-bed gasifier performance. The exact effects of each of the parameters will require empirical determination; however, each of them has been identified as significant to IGCC gasifier performance.

\subsubsection{Free Swelling Index (FSI)}

This index will likely have the greatest single influence upon gasifier coal throughput (gas output). The literature indicates about a four to one range of output over the free swelling index (FSI) range of zero (0) to eight (8). Clearly, if a standard IGCC gasifier is to be applicable to all U.S. coals up to a FSI of eight (8), this influence must be recognized, planned, and designed. 
TABLE 7

GE DATA FOR FIXED-BED GASIFIER PERFORMANCE

\begin{tabular}{|c|c|c|c|c|c|c|}
\hline & $\begin{array}{c}1 \\
\text { Baseline } \\
\end{array}$ & $\begin{array}{c}2 \\
\text { Low } \\
\text { Steam } \\
\end{array}$ & $\begin{array}{c}3 \\
\text { High } \\
\text { Steam } \\
\end{array}$ & $\begin{array}{c}4 \\
\text { Alternate } \\
\text { Stirrer } \\
\end{array}$ & $\begin{array}{c}5 \\
\text { Half } \\
\text { Flow } \\
\end{array}$ & $\begin{array}{l}6 \\
\text { High } \\
\text { Blast } \\
\end{array}$ \\
\hline Test Run & $33-1$ & $34-2$ & $34-1$ & $33-2$ & $33-2$ & $34-2$ \\
\hline Raw Coal, lbm/hr & 1858 & 1616 & 1627 & 1821 & 893 & 1848 \\
\hline Coal Moisture, \% & 9.0 & 8.6 & 7.5 & 9.0 & 8.2 & 8.5 \\
\hline Dry Coal, lbm/hr & 1691 & 1467 & 1504 & 1650 & 820 & 1691 \\
\hline Dry Fines Carryover, $\%$ & 4 & 2.3 & 3.4 & 2.0 & 1.4 & 1.3 \\
\hline Hot Gas T. ${ }^{\bullet} \mathrm{F}$ & 1084 & 1080 & 1150 & 1046 & 948 & 1109 \\
\hline Quench Exit T. ${ }^{\bullet} \mathrm{F}$ & 342 & 330 & 365 & 342 & 336 & 340 \\
\hline Raw Gas, lbm/hr & 6306 & 6409 & 3261 & 6480 & & \\
\hline \multicolumn{7}{|l|}{$\begin{array}{l}\text { Gas Composition, } \\
\text { Vol. \& Dry }\end{array}$} \\
\hline $\mathrm{H}_{2}$ & 20.9 & 17.1 & 21.6 & 20.4 & 19.9 & 21.5 \\
\hline$\infty$ & 16.5 & 24.6 & 9.8 & 18.3 & 16.4 & 18.5 \\
\hline $\mathrm{CO}_{2}$ & 12.4 & 6.4 & 17.1 & 11.4 & 12.9 & 11.5 \\
\hline $\mathbf{N}_{2}$ & 45.0 & 47.4 & 46.1 & 44.6 & 44.7 & 43.4 \\
\hline $\mathrm{CH}_{4}$ & 4.2 & 3.8 & 4.5 & 4.3 & 5.2 & 4.3 \\
\hline $\mathrm{H}_{2} \mathrm{~S}$ & .3 & .3 & .3 & .3 & .3 & .3 \\
\hline $\begin{array}{c}\text { Gas Heating Value, } \\
\text { BTU } / \mathrm{sft}^{3}\end{array}$ & 163 & 171 & 146 & 168 & 168 & 171 \\
\hline Gas Water Content, Vol. \% & 18.4 & 10.3 & 27.4 & 17 & 15.8 & 19.4 \\
\hline Tar Yield Wt \% Dry Coal & 3.1 & 2.9 & 4.7 & 3.2 & & \\
\hline Carbon Efficiency, $\%$ & 84 & 95 & 87 & 88 & 90 & 89 \\
\hline Cold Gas Efficiency, $\%$ & 73 & 84 & 73 & 78 & 79 & 80 \\
\hline $\begin{array}{c}\text { Enthalpy Conversion } \\
\text { Effic. } \%\end{array}$ & 66 & 78 & 62 & 70 & 71 & 71 \\
\hline Steam Utilization $\%$ & 57 & 73 & 42 & 61 & 65 & 50 \\
\hline
\end{tabular}


TABLE 8

TYPICAL LURGL PERFORMANCE DATA

EOR AIR-BLOWN OPERATION

\begin{tabular}{|c|c|}
\hline $\begin{array}{l}\text { Coal } \\
\text { HHV. Btu/lb }\end{array}$ & $\begin{array}{r}\text { Subituminous } \\
12.700 \\
\end{array}$ \\
\hline Air, scf/scf of crude gas & 0.51 \\
\hline $\begin{array}{l}\text { Steam (excluding jacket steam) } \\
\mathrm{lb} / \mathrm{scf} \text { of crude gas }\end{array}$ & 0.012 \\
\hline Air/Coal ratio, lb/lb & 2.3 to 2.7 \\
\hline Steam/Coal Ratio, lb/lb & 1 to 1.5 \\
\hline Crude gas, scf/1000 lb daf coal & 62,223 \\
\hline $\begin{array}{l}\text { Tar, oil, naphtha, lb/1000 } \\
\text { daf coal }\end{array}$ & 72 \\
\hline $\begin{array}{l}\text { Gas analysis (dry and sulfur-free } \\
\text { crude gas), }\end{array}$ & $\%$ \\
\hline $\mathrm{CO}_{2}$ & 14.0 \\
\hline$\infty$ & 15.8 \\
\hline $\mathrm{H}_{2}$ & 25.0 \\
\hline $\mathrm{CH}_{4}$ & 5.0 \\
\hline $\mathrm{C}_{n} \mathrm{H}_{m}$ & 0.2 \\
\hline $\mathrm{N}_{2}$ & 40.0 \\
\hline
\end{tabular}

${ }^{\circ}$ Volatile matter $=32.0 \%$, Fischer $\operatorname{tar}=4 \%$

+ Caking, volatile matter $=39.0-45.0 \%$ 
Table 9

Performance Characteristics of Moving-Bed Gasifiers

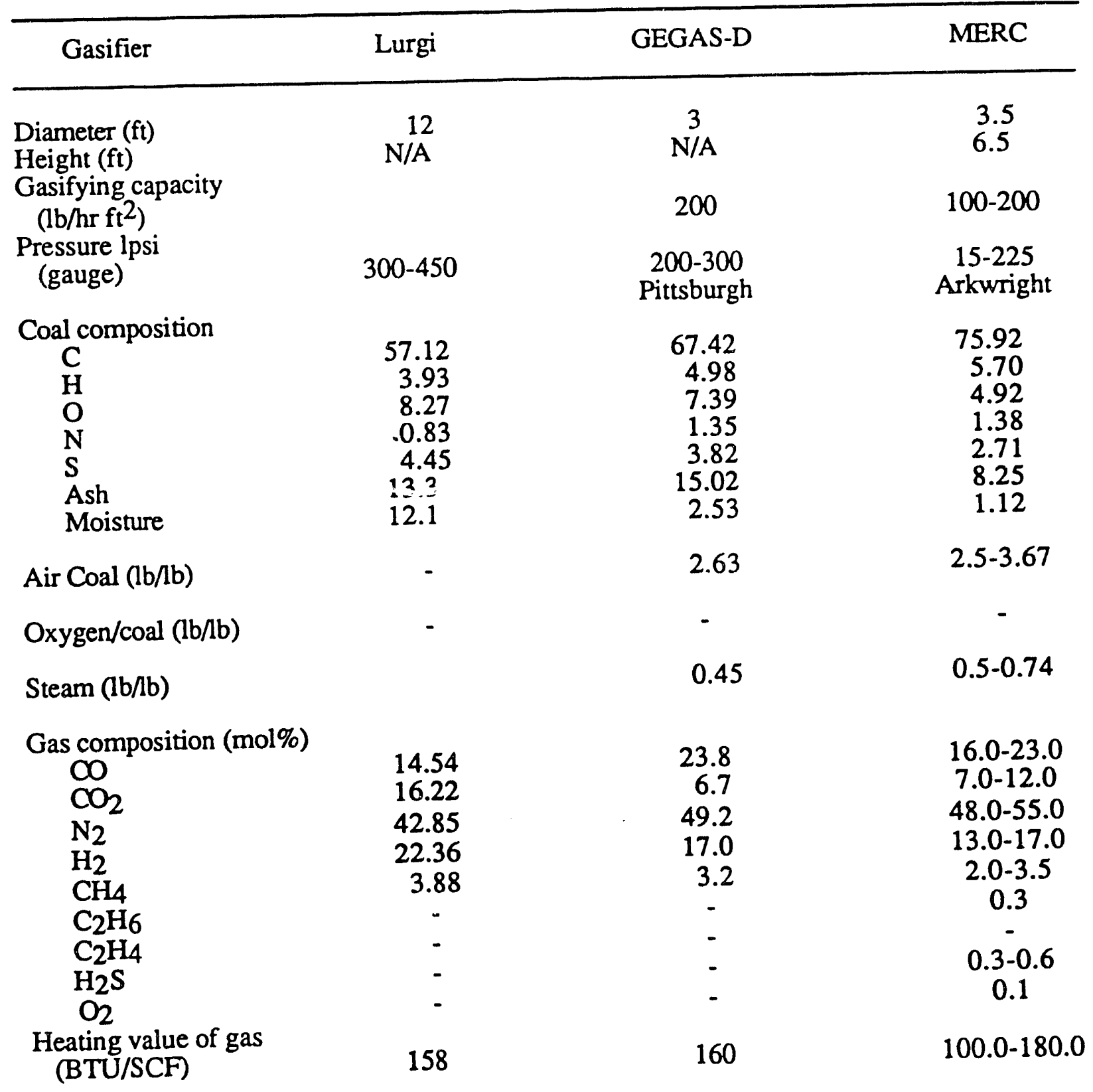

Nowacki, Perry ed. Coal Gasification Processes. Noyes Data Corp.; Park Ridge, New Jersey; 1981. 
Table 10

Process Data and Gas Produced for the Lurgi Gasifier

\begin{tabular}{|c|c|}
\hline Feed Coal & $\begin{array}{c}\text { EPRI } \\
\text { Study } \\
\text { Illinois No. } 6\end{array}$ \\
\hline $\begin{array}{l}\text { Ash\% } \\
\text { Moisture \% } \\
\text { Size, inches } \\
\text { HHV, Btu/lb } \\
\text { Ton/day/gasifier }\end{array}$ & $\begin{array}{c}9.6 \\
4.2 \\
1 / 4-11 / 2 \\
12,235 \\
625\end{array}$ \\
\hline $\begin{array}{l}\text { Gasifiers } \\
\text { Inner diameter, } \mathrm{ft} \\
\text { Number } \\
\text { Stirred } \\
\text { Water-cooled } \\
\quad \text { grate }\end{array}$ & $\begin{array}{l}- \\
16^{*} \\
\text { Yes } \\
-\end{array}$ \\
\hline $\begin{array}{l}\text { Gasifying medium } \\
\text { Oxygen, tpd } \\
\text { Oxygen, tpd } \\
\text { of coal } \\
\text { Air, tpd } \\
\text { Air, ton/ton } \\
\text { of coal } \\
\text { Steam, tpd } \\
\text { Steam, ton/ton } \\
\text { of coal }\end{array}$ & $\begin{array}{c}\text { Air-steam } \\
- \\
- \\
1,390 \\
2.22\end{array}$ \\
\hline $\begin{array}{l}\text { Product gas } \\
\text { HHV, Btu/scf } \\
\text { MMscfd/gasifier } \\
\text { Exit temperature, }{ }^{\circ} \mathrm{F}\end{array}$ & $\begin{array}{l}179 \\
47 \\
955\end{array}$ \\
\hline $\begin{array}{l}\text { Raw gas, mol \% } \\
\mathrm{CO} \\
\mathrm{H}_{2} \\
\mathrm{CH}_{4} \\
\mathrm{C}_{\mathrm{n}} \mathrm{H}_{\mathrm{m}} \\
\mathrm{H}_{2} \mathrm{~S}+\mathrm{COS} \\
\mathrm{N}_{2}+\mathrm{Ar} \\
\mathrm{CO}_{2} \\
\mathrm{HHV}, \mathrm{Btu} / \mathrm{scf}\end{array}$ & $\begin{array}{r}16.52 \\
23.76 \\
3.94 \\
0.10 \\
0.75 \\
41.49 \\
13.44\end{array}$ \\
\hline
\end{tabular}

Nowacki, Perry ed. Coal Gasification Processes. Noyes Data Corp.; Park Ridge, New. Jersey; 1981 


\section{Table 11}

\section{INPUT STREAMS}

- Coal: (Stream No. 1)

- Type:

New Mexico

- Size:

(in)

- Rate: $\mathrm{g} / \mathrm{sec}-\mathrm{m}^{2}$

$\left(\mathrm{lb} / \mathrm{hr}-\mathrm{ft}^{2}\right)$

Subbituminous C

2.0 to 44.4

(0.08 to 1.75 )

337

(248)

- Composition:

Volatile matter

$31.0 \%$

Moisture

Ash

Sulfur (dry basis)

$16.4 \%$

$17.8 \%$

$0.63 \%$

- HHV: J/kg

(Btu/lb)

- Swelling number:

$2.03 \times 10^{7}$

(8838)

- Caking index:

- Steam: (Stream No. 2)

2

0

$0.965 \mathrm{~kg} / \mathrm{kg}$

DAF coal

NA

- Oxygen: (Stream No. 3)

- Air. (Stream No. 3)

$1.99 \mathrm{~kg} / \mathrm{kg}$

DAF coal

\section{GAS OUTPUT}

- Gasifier pressure:

$2.07 \mathrm{MPa}$

(300 psia)

0.485

- Steam /air (kg/kg):

- Gas outlet

Data not available temperature:

- Gas production rate: $\quad \mathrm{Nm} 3 / \mathrm{kg}$ coal (scf/lb coal)

Cavanaugh. E.C., et al. Environmental Assessment Data Base for Low/Medium-Btu Gasification Technology, Vol II. Radian Corp., Austin, Texas: Nov 1977 (EPA/600/7-77/125B) 


\section{Table 12}

Gas Composition and Heating Value for Typical Air Blown, Low-Btu Gasifiers

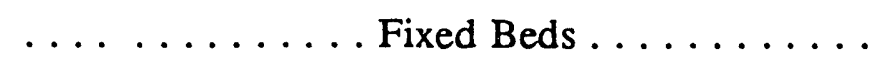

\begin{tabular}{lcccr}
\multicolumn{1}{c}{$\begin{array}{c}\text { Gas } \\
\text { Component }\end{array}$} & Single-Stage & Two-Stage & $\begin{array}{c}\text { Pressurized } \\
\text { Single-Stage }\end{array}$ & $\begin{array}{c}\text { Fluidized } \\
\text { Beds }\end{array}$ \\
H2 & 15.7 & 16.0 & 21.8 & 13.2 \\
$\mathrm{CO}$ & 25.4 & 29.8 & 14.8 & 21.5 \\
$\mathrm{CO} 2$ & 4.7 & 3.3 & 14.8 & 7.0 \\
$\mathrm{CH} 4$ & 3.2 & 2.9 & 6.1 & 0.5 \\
$\mathrm{C} 2+$ & - & - & - & - \\
N2 & 50.5 & 47.3 & 41.7 & 57.7 \\
Other & 0.5 & 0.7 & 0.8 & 0.1 \\
& & & & \\
Heating value, Btu/scf & 164 & 176 & 180 & 117
\end{tabular}

Nowacki, Perry ed. Coal Gasification Processes. Noyes Data Corp.; Park Ridge, New Jersey; 1981. 


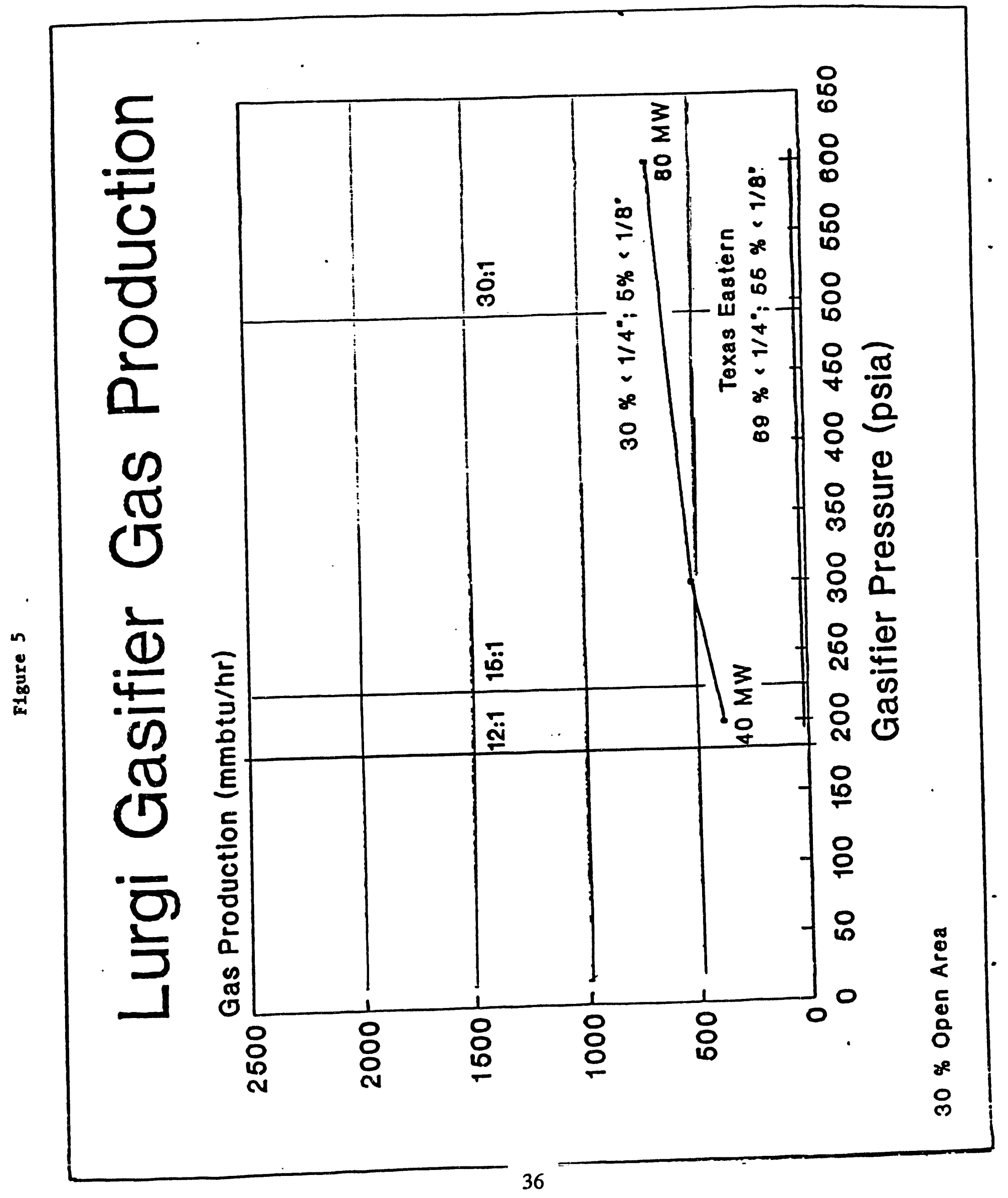




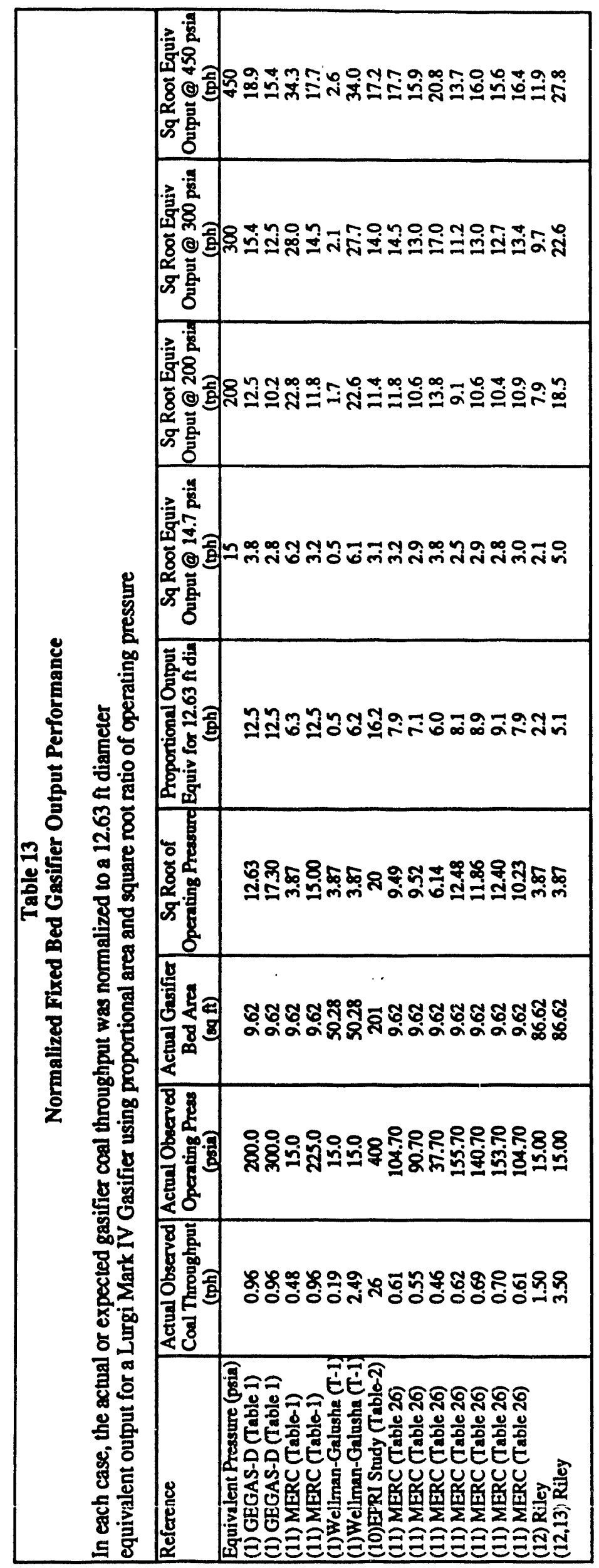




\section{Empirical Gasifier Output Prediction}
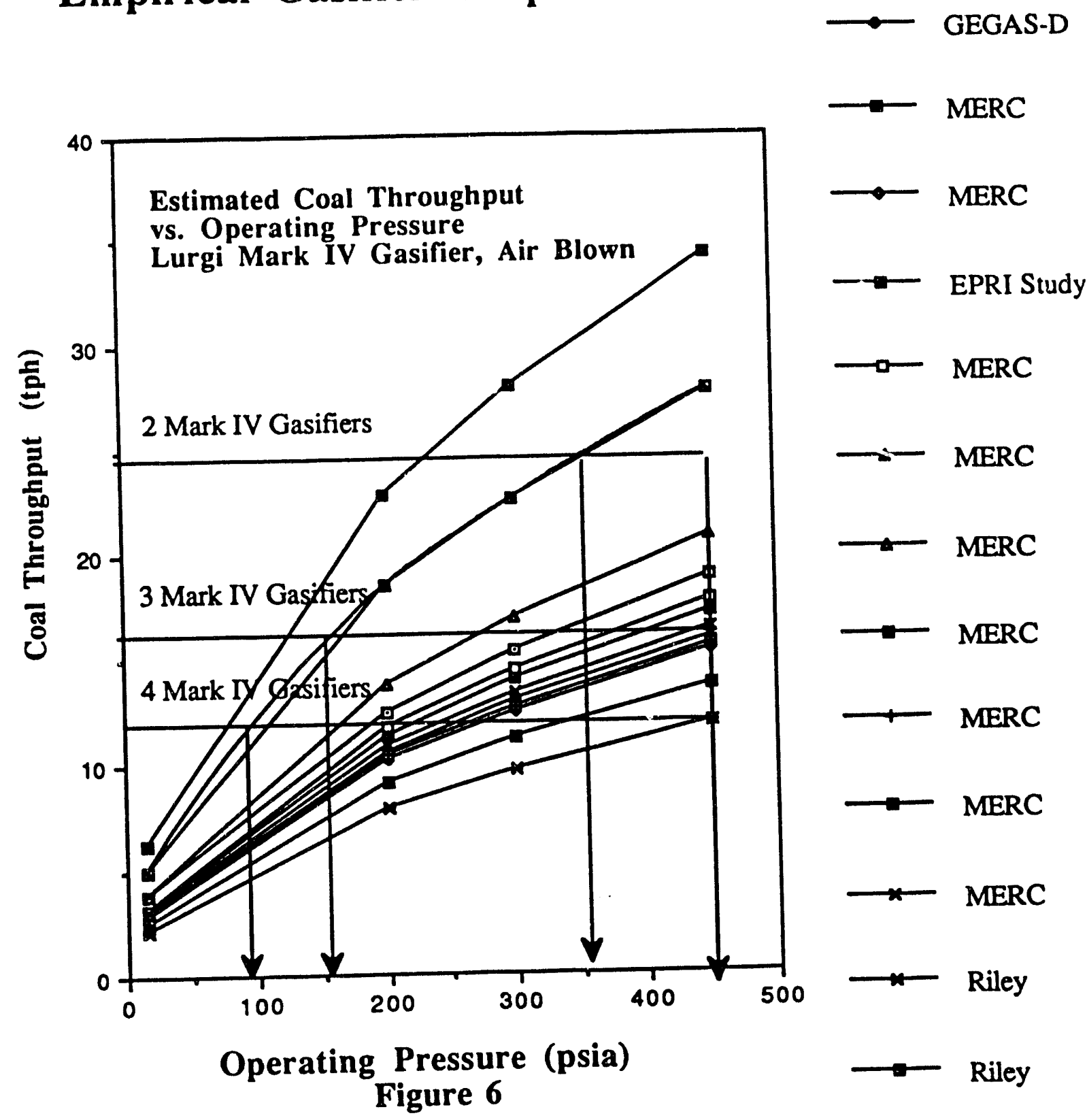


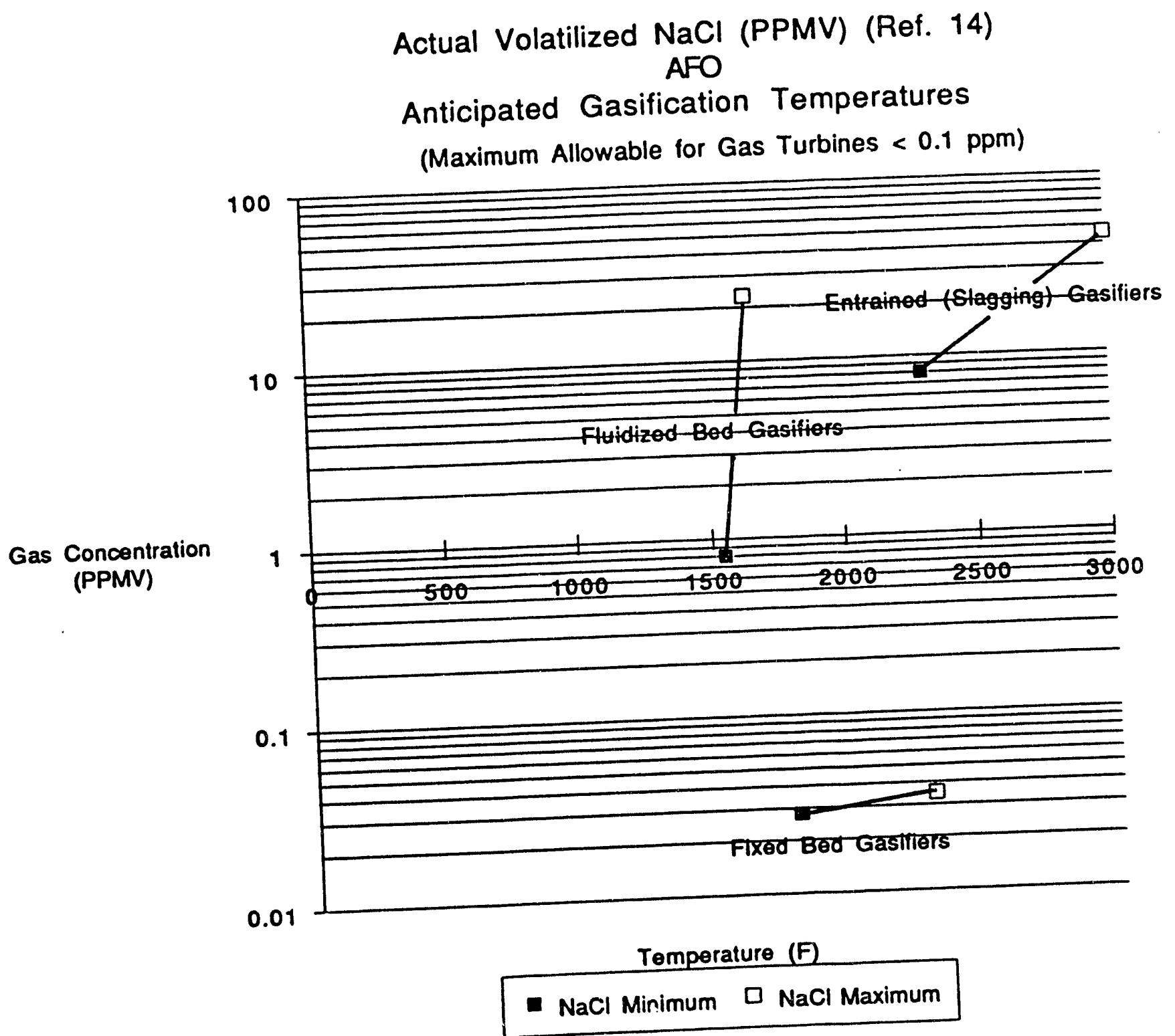

Figure 7 


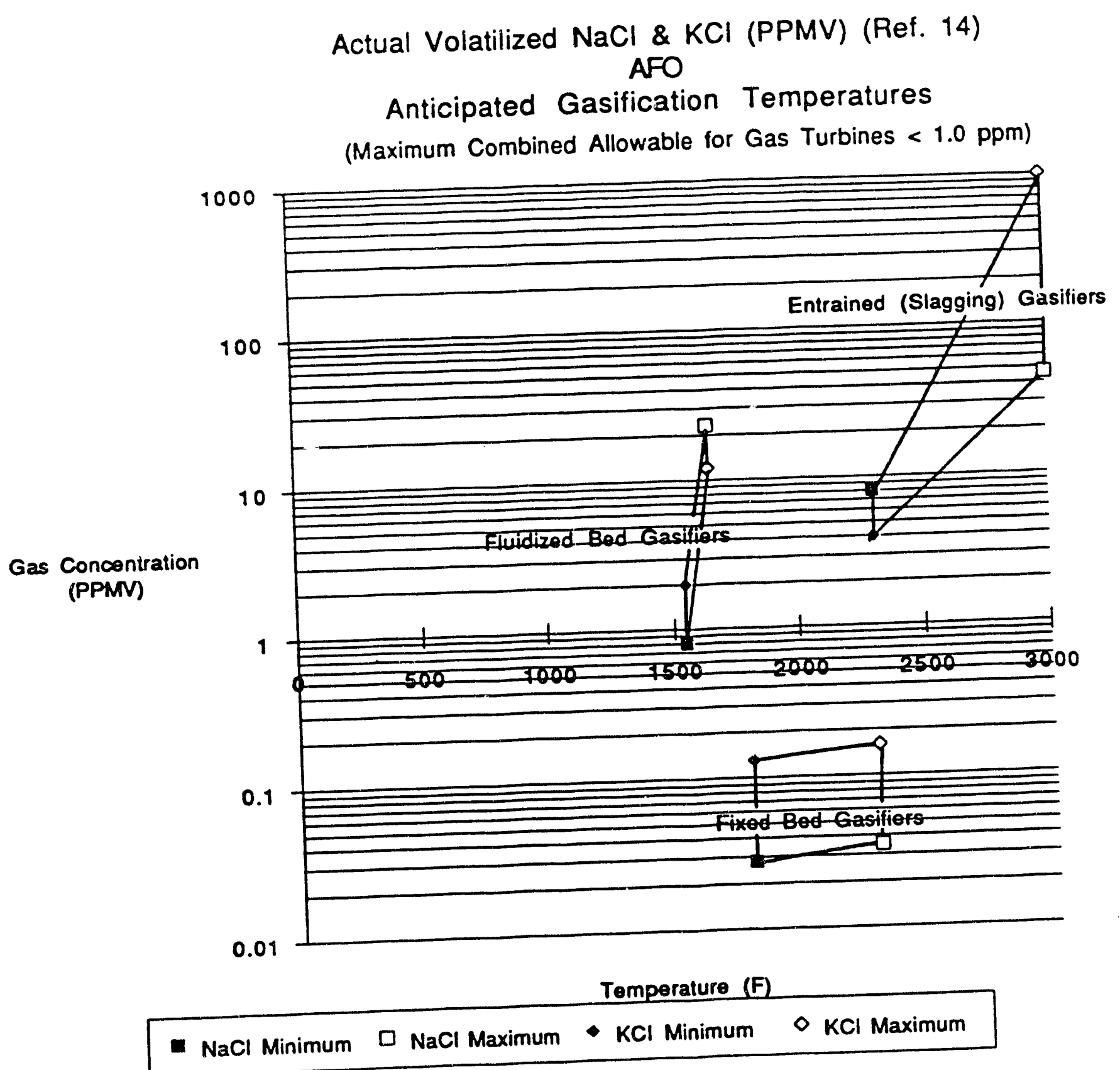

Figure 8 


\subsubsection{Ash Fusion Temperatures}

Ash fusion temperature affects the amount of steam that must be added to the gasifier to maintain the ash below its softening temperature. The lower the ash fusion temperature, the more steam that is required to prevent clinker formation.

\subsubsection{Ammonia \& Cyanide Production}

All fixed bed gasifiers are likely to produce some ammonia and cyanide. A relatively large fraction of this "fuel bound nitrogen" is likely to become NOx when the gas is combusted in the gas turbine. There appears to be little that can be done in the gasifier to mitigate fuel bound nitrogen production, and therefore down stream NOx reduction and removal strategies (e.g. stagea combustion or SCR) are expected to be necessary and employed.

\subsubsection{Volatilized Alkali Production}

From available data, it appears that the hotter the gasification process, the greater the volatilized alkali production. Slagging entrained bed gasifiers produce about three orders of magnitude more sodium and potassium than gas turbine manufacturers consider acceptable. Fluid bed gasifiers produce about two orders of magnitude more than is acceptable. Only fixed bed non-slagging gasifiers appear capable of maintaining sufficiently low volatilized alkali levels for direct hot gas utilization gas turbines without post gasifier treatment of the alkali vapors.

\subsubsection{Tar Production}

Tar production can be minimized by various operational techniques, however some tar should always be expected from a fixed bed gasifier. Several gasifier suppliers have reduced tar production by readmitting volatiles produced gas back through the char bed region. 


\subsubsection{Thermal-phoresis}

It is known that when gasifier exit temperatures are maintained well above the tar condensation range such that the tars and heavy oils tend to crack, resulting coke has an affinity for accumulating on any and all duct surfaces, irrespective of duct refractory temperatures. The term "thermal-phoresis" has been used to describe this phenomenon. Historically, the best way to deal with it is to minimized the extent of any ductwork between the gasifier outlet and the hot gas cleanup unit (HGCU). Other obvious treatments such as soot blowers may have deleterious affects on the HGCU process.

\subsubsection{Ash Carbon Content}

Ideally, gasification should proceed with near complete utilization of the carbonaceous fraction of the coal. During upset conditions, such as gas channeling, significant quantities of unburned carbon may occur. Such channeling is often the result of agglomeration caused clinkering and is typically associated with high free swelling coal properties. This negatively affects both process efficiency and ash disposal. Ash disposal cost is affected by its carbon content. Since coal ash, which contains less than $5 \%$ unburned carbon, can usually be stabilized, a reasonable goal for the standard IGCC gasifier is to maintain less than $5 \%$ carbon in the bottom ash.

\subsubsection{Pressure Containment}

It is anticipated that the standard IGCC gasifier will be operated at various pressures depending primarily upon output required and coal characteristics. Pressure drop across the gasifier in addition to the attendant pressure losses of the systems downstream of the gasifier ( $\operatorname{tar} \&$ particulate removal, desulfurization/regeneration, etc.), culminate in the need for a booster compressor (or similar device) which allows the gasifier to operate at significantly greater pressures than that of the gas turbine. This presents a formidable need to adequately seal all gasifier penetrations against a hot, high pressure environment. Several gasifier suppliers have met this challenge to pressures in the 350 psig range (SASOL Lurgi - 400 psig; Shell - 450 psig; Texaco $-600 \mathrm{psig}$ ). The remaining question is one of maintainability of the hardware involved. 


\subsubsection{Coal Feed System Losses}

It is well known that any pressurized lock hopper arrangement has an associated thermal loss from gasifier hot gas product venting. Such venting is necessitated by the admittance of hot raw gas product during the coal feed sequence. This hot raw gas is at operating pressure and hence must be vented before the coal bunker slide valve is opened to atmosphere. Depending upon where and how the gas is vented, it can be significant loss to the process.

\subsubsection{Coal Sizing}

Most fixed bed coal gasifiers specify very tightly controlled feed gradation. It is unlikely that any fixed bed coal gasifier commercially available today will guarantee acceptable performance with significant fines content in the coal feedstock. Clearly, this shortcoming must be addressed either by alternative utilization of fines, or gasifier design changes intended to accommodate run of mine coals. None exist today.

\subsubsection{Turndown}

The range of gasifier operation from steady state full load to "banked" or "standby" pulsed condition, introduces a myriad of interdependant process phenomena which serve to complicate the whole issue of "turndown". Gasifier conditions, such as the relative position of the drying, devolatization, gasification, combustion, and ash burnout zones, are likely to be affected by externally forced operational changes to the gasification process.

\subsection{Gasifier Installation and Agreements}

Of concern to the operation of an air-blown, fixed-bed gasifier are the following non-technical issues:

- Typical plant problem areas

- Plant operating characteristics

- Personnel leveis and capability requirements

- Plant economics

- Lurgi role \& deliverables including services provided by license

- Cost basis 
The available definitive literature is very sparse with respect to these areas in that most presentations of gas plant data are for the entire plant and do not treat the gasifier as a defined entity. However, Table 14 does show the gasification, quench, and shift conversion applicable to SNG applications (the typical Lurgi scope of supply) as resulting in 23\% of Plant capital costs. Previous CRSS discussions with Lurgi indicate that such a scope for 2 (two) Mark IV gasifiers equates to approximately $\$ 80$ million dollars. Based upon CRSS personnel experience with Lurgi systems, this yields Mark IV estimated costs of approximately $\$ 15$ million each. Others CRSS discussions with Lurgi recently have yielded similar budgetary estimates.

With regard to Lurgi scope of supply questions, recent CRSS discussions with Lurgi (March 1990) have established the following:

- Lurgi does not manufacture any equipment.

- Technology use for a specific installation is the license one receives from Lurgi.

- Lurgi performance guarantees are coal specific but are complete with respect to output, composition, efficiency, and cost.

- Lurgi will quote, on a limited basis, a reduced scope from that involving coal gas cleanup to include only gasifier output at the effluent flange.

- Lurgi will accommodate mildly caking coals (FSI approximately 3-4) in the fixed bed design utilizing a deep bed stirrer.

With respect to plant operating personnel and plant operating characteristics, discussions with Coastal Coal management relative to the Mark IV facilities in the US indicates minimal problems were experienced (after shakedown) at the Great Plains facility. Further discussion with these operating personnel will be held after finalization of Lurgi secrecy agreements. 


\section{Table 14 \\ Estimated Coal Gasification Capital Costs}

ALLOCATION OF PRODUCT PRICE

Single product (SNG), no allocation necessary

UNIT OPERATION CONTRIBUTION TO COMPOSITE

PRODUCT PRICE (CAPITAL INVESTMENT EFFECTS ONLY)

UNIT OPERATION

Coal Storage

Coal Preparation

Coal Feed

Gasification

Raw Gas Quench

Shift Conversion

Acid Gas Removal

Methanation

Sour Water Treatment

Sulfur Recovery

Solids Disposal

Steam And Utility Systems

Plant Water

Oxygen Plant

General Facilities

OTHER INFORMATION

ANNUAL COSTS

Catalysts and Chemicals

Water (60c/Mgal)

Labor

Administration and Overhead

Supplies

Local Taxes and Insurance

GROSS ANNUAL COSTS

BY-PRODUCTS

Sulfer (\$26/to)

$\mathrm{NH}$ (\$165/ton)

Oil, Naphtha, Tar

Fines (\$0.41/MMBtu)

NET ANNUAL COSTS
$\%$

1.7

3.1

23.0

14.1

7.0

2.3

6.5

0.4

21.4

2.6

7.8

10.0

100.0

Reference

0.82

7.61

43.79

13.32
$\$ M M / y r$

10.77

0.69

31.80

19.08

16.21

35.65

114.20

(65.54)

Factored Estimates for Western Coal Commerical Concepts, C.F. Braun, FE-2240-5, October 1976.

Meyers, Robert A. Handbok Of Synfuels Technolegy, McGraw Hill Book Company. New York: 1984 


\section{REFERENCES}

(1) Cavanaugh, E.C., et al "Environmental Assessment Data Base for Low/Medium Btu Gasification Technology", Vol II, Radian Corp., Austin, TX, Nov, 1977 (EPAV600/777/125B)

(2) Sharman, R.B. et al, "The British Gas/Lurgi Slagging Gasifier - What It Can Do", Coal Technology '80, 3rd International Coal Utilization Exhibition and Conference, November 18-20, 1980, Houston, Texas

(3) Herbert, P.K. et al, "Lurgi's CFB Gasification Technology for Combined Cycle Power Generation (Part I) and Gas Production from Biomass (Part II)", Eighth Annual EPRI Conference on Coal Gasification, Proceedings August, 1989, Palo Alto, California

(4) Webb, Rodney M. et al, "The Dow Syngas Project Recent Operating Experience", Eighth Annual EPRI Conference on Coal Gasification, Proceedings August, 1989, Palo Alto, Califomia

(5) Personal communication with Mr. Chuck Howser, Shell Chemical Corp., April, 1990

(6) Tetsuei Sueyama, et al, "Four-Year Operating Experience With Texaco Coal Gasification Process In Ube Ammonia", Eighth Annual EPRI Conference on Coal Gasification, Proceedings August, 1989, Palo Alto, California

(7) Personal communication with Mr. Duncan, R. McRae of MAN-GHH "MBG Coal Gasification Technology", February, 1990

(8) Personal communication with METC, March, 1990

(9) Vogt, Erich V. et al, "The Shell Coal Gasification Process", Nowacki, Perry ed., "Coal Gasification Processes". Noyes Data Corp.;Park Ridge, NJ, 1981 
REFERENCES - continued

(10) Nowacki, Perry ed.,"Coal Gasification Processes", Noyes Data Corp., Park Ridge, New Jersey, 1981

(11) Smoot, L. Douglas, and Philip J. Smith, "Coal Combustion And Gasification", Plenum Press, New York, 1985

(12) Personal communication with Riley Consolidated, March, 1990

(13) Dr. Fred L. Jones, et al, "Source Test and Evaluation of a Riley Gas Producer Firing North Dakota Lignite", Symposium on Environmental Impacts of Fuel Conversion Technology, Denver, CO, October 26, 1981

(14) "Ranges of Contaminant Concentrations from Illinois No. 6 Coal Oxygen Blown Gasifiers and Combustors", DOE/MC/23088.2532 


\title{
Preliminary Assessment of Optimum Combinations of Combustion Turbine and Gasifier/HGCU Hardware
}

\author{
Section 2
}

January 1991

Work Performed Under Contract No. DE-AC21-89MC26291

For

U.S. Department of Energy

Office of Fossil Energy

Morgantown Energy Technology Center

P.O. Box 880

Morgantown, West Virginia 26507-0880

B y

CRS SIRRINE, INC.

Power Division

P.O. Box 5456

1041 East Butler Road

Greenville, South Carolina 29606-5456 


\subsection{Summary}

The objective of the study covered by Contract DE-AC21-89MC26291 is to develop an integrated gasification combined cycle (IGCC) for electric power generation. This IGCC system will incorporate an air-blown, fixed-bed gasifier and a hot gas clean up (HGCU) unit.

This section addresses:

1) Performance data of currently available gas turbines,

2) Advantages/disadvantages of candidate gas turbines matched with gasifier/HGCU module, and

3) Performance characteristics of near term commercially available (by the year 2000 AD) gas turbines with an air-blown, fixed-bed gasifier/HGCU module.

The standardized IGCC system is to be compatible with three sizes of coal fueled plants: $50 \mathrm{MW}(\mathrm{e}), 100 \mathrm{MW}(\mathrm{e})$, and $200 \mathrm{MW}(\mathrm{e})$. The gasifier will produce a hot raw gas for hot gas clean up and direct combustion in a gas turbine.

The data reviewed has been developed principally by the Department of Energy's Morgantown Energy Technology Center (METC), General Electric, Westinghouse, Asea Brown Boveri, the Lurgi Corporation, and Thermoflow.

Gas turbine compressor surge is a potential limiting factor in power output and efficiency when applied to the steam cooled air-blown, fixed-bed coal gasification IGCC system. Water injection for gasifier temperature control reduces this concern. 


\subsection{Gas Turbine Selection}

\subsubsection{Overview Descriptions of Candidate Gas Turbines}

Table 1 is a list of commercially available gas turbines as compiled by Maher Elmasri, author of GTPro. [1] This table cites ISO (59 F, 60\% Relative Humidity) no-loss performance for gas turbines fired on methane. Gas turbines that could be integrated into a $50 \mathrm{MW}, 100 \mathrm{MW}$, or $200 \mathrm{MW}$ IGCC system were selected from Table I based on the size (power output) of the gas turbine and the manufacturers experience with burning low-Btu fuels. (see Table 2)

Gas turbines must be selected to complement nominal $50 \mathrm{MW}(\mathrm{e}), 100 \mathrm{MW}(\mathrm{e})$, and 200 MW(e) plant designs. The gas turbine power contribution to each size plant must be established to begin the selection process. General Electric has done extensive research with combined cycle systems and has determined that for a standard combined cycle plant with an unfired heat recovery steam generator and a gas turbine fired with natural gas, the gas turbine will provide approximately two-thirds of the total power. [2]

Three principal manufacturers, General Electric, Westinghouse, and Asea Brown Boveri, are participating in IGCC projects. General Electric's experience is with the Texaco Gasification Process that is being used in the Cool Water IGCC plant in Daggett, California. Westinghouse has provided the gas turbines for the Dow Gasification Process used in an IGCC power plant in Plaquemine, Louisiana. Asea Brown Boveri is working in conjunction with Shell Oil Company to develop an IGCC power plant in the Netherlands. All of the commercial experience to date has been with oxygen-blown gasifiers. An oxygen-blown gasifier produces raw gas with a lower heating value of approximately 300 Btu/scf. From an air-blown gasifier, the raw gas has a lower heating value of approximately $140 \mathrm{Btu} / \mathrm{scf}$. Although few commercial applications utilize fuels with heating values below $100 \mathrm{Btu} / \mathrm{scf}$, laboratory tests have indicated that stable combustion can be maintained with lower heating values down to $80 \mathrm{Btu} / \mathrm{scf}$. [3]

The following areas must be addressed in order to burn a low-Btu fuel. 
Table 1

Nominal ISO No Loss performance on $\mathrm{CH} 4$

Revised: 02-21-1990

\begin{tabular}{|c|c|c|c|c|c|c|}
\hline Model & $\begin{array}{l}\text { Shafts } \\
\text { No. }\end{array}$ & $\begin{array}{l}\text { Speed } \\
\text { RPM }\end{array}$ & $\begin{array}{l}\text { Press. } \\
\text { PR } \\
\end{array}$ & $\begin{array}{c}\text { Output } \\
\text { kWe }\end{array}$ & $\begin{array}{c}\text { H.R. } \\
\text { Btu/kWh }\end{array}$ & $\begin{array}{c}\text { Efficiency } \\
\text { \%LHV } \\
\end{array}$ \\
\hline G.E. 5371PA & 1 & 5100 & 10.2 & 26840 & 11690 & 29.2 \\
\hline G.E. 6541B & $i$ & 5100 & 11.8 & 38920 & 10790 & 31.6 \\
\hline G.E. 7111EA & 1 & 3600 & 12.4 & 84620 & 10360 & 32.9 \\
\hline G.E. $7191 \mathrm{~F}$ & $i$ & 3600 & 13.7 & 151340 & 9650 & 35.4 \\
\hline G.E. LM500 & 2 & 7000 & 14.5 & 3860 & 11540 & 29.6 \\
\hline LM/TG 1600 & 3 & 7000 & 21.7 & 13520 & 9510 & 35.9 \\
\hline LM/TG2500PE & 2 & 3600 & 18.4 & 22190 & 9420 & 36.2 \\
\hline LM/TG2500PH & 2 & 3600 & 16.4 & 19700 & 9630 & 35.4 \\
\hline LM/TG5000PD & 3 & 3600 & 25.5 & 33350 & 9390 & 36.3 \\
\hline LM5000ST 80 & 3 & 3600 & 33.0 & 46300 & 8170 & 41.8 \\
\hline LM5000ST 120 & 3 & 3600 & 33.0 & 51500 & 7885 & 43.3 \\
\hline LM/TG5000PC & 3 & 3600 & 25.3 & 33760 & 9400 & 36.3 \\
\hline UTC FT4C-3F & 3 & 3600 & 14.0 & 29810 & 10960 & 31.1 \\
\hline Sol Satum & 1 & 22120 & 6.7 & 1080 & 14785 & 23.1 \\
\hline Sol Centaur & 1 & 14950 & 9.3 & 3880 & 12300 & 27.7 \\
\hline Sol Mars & 2 & 8568 & 15.7 & 8840 & 10976 & 31.1 \\
\hline Jupitr/GT35 & 3 & 3600 & 2.0 & 16360 & 10650 & 32.0 \\
\hline Alsn 501KB5 & 1 & 14250 & 9.3 & 3725 & 12450 & 27.4 \\
\hline Alisn 570KA & 2 & 11500 & 12.0 & 4610 & 12250 & 27.9 \\
\hline Alisn 571KA & 2 & 11500 & 12.7 & 5590 & 10650 & 32.0 \\
\hline CW 251 B 10 & 1 & 5420 & 14.2 & 42300 & 10600 & 32.2 \\
\hline W 501 D5 & $i$ & 3600 & 14.2 & 106800 & 10100 & 33.8 \\
\hline ABB GT 8 & 1 & 6300 & 16.3 & 46950 & 10830 & 31.5 \\
\hline ABB GT IIN & i & 3600 & 12.4 & 81600 & 10715 & 31.8 \\
\hline KWU V84.2 & $i$ & 3600 & 10.6 & 103400 & 10250 & 33.3 \\
\hline ABB GT 10 & 2 & 7700 & 13.6 & 21800 & 10420 & 32.7 \\
\hline RRSpeySK15 & 3 & 5220 & 18.5 & 11630 & 10530 & 32.4 \\
\hline Avon/Cooper & 2 & 5500 & 9.0 & 14600 & 12000 & 28.4 \\
\hline RB211/Coopr & 3 & 4800 & 20.0 & 25250 & 9600 & 35.5 \\
\hline Drss DC990 & 2 & 7200 & 12.5 & 4210 & 11830 & 28.8 \\
\hline Rstn TB5000 & 2 & 7950 & 7.0 & 3830 & 13500 & 25.3 \\
\hline Rstn Torndo & 1 & 11085 & 12.0 & 6215 & 11390 & 30.0 \\
\hline Mtsb MF111A & 1 & 9660 & 12.8 & 12850 & 11150 & 30.6 \\
\hline Mtsb MFI11B & 1 & 6990 & 14.6 & 14850 & 10950 & 31.2 \\
\hline NvPgn PGT10 & 2 & 7900 & 14.0 & 9980 & 10500 & 32.5 \\
\hline Mtsui SB60 & 2 & 5680 & 12.1 & 12650 & 11460 & 29.8 \\
\hline G.E. $9161 \mathrm{E}$ & 1 & 3000 & 12.2 & 118800 & 10220 & 33.4 \\
\hline G.E. $9161 \mathrm{~F}$ & $i$ & 3000 & 13.7 & 217900 & 9650 & 35.4 \\
\hline MW 701D(5) & 1 & 3000 & 13.8 & 133750 & 9980 & 34.2 \\
\hline ABB GT 13D2 & 1 & 3000 & 12.5 & 100500 & 10640 & 32.1 \\
\hline ABB GT 13E & 1 & 3000 & 14.1 & 148000 & 9855 & 34.6 \\
\hline KWU V94.2 & 1 & 3000 & 10.7 & 150300 & 10210 & 33.4 \\
\hline UTC FT8 & 3 & 3600 & 20.0 & 25420 & 8920 & 38.3 \\
\hline MW501F & 1 & 3600 & 14.2 & 152300 & 9800 & 34.8 \\
\hline KWU V64.3 & 1 & 5600 & 15.8 & 55000 & 10060 & 33.9 \\
\hline CW 251 B12 & 1 & 5400 & 14.8 & 47700 & 10420 & 32.7 \\
\hline
\end{tabular}


Table 2

\begin{tabular}{cccccc} 
& Speed & Press. & Output & H.R. & Efficiency \\
Model & RPM & PR & kWe & Btu/kWh & $\%$ LHV \\
\hline
\end{tabular}

50 MW Cycle Available Turbines

$\begin{array}{llllll}\text { LM/TG5000PD } & 3600 & 25.5 & 33350 & 9390 & 36.3 \\ \text { LM/TG5000PC } & 3600 & 25.3 & 33760 & 9400 & 36.3\end{array}$

100 MW Cycle Available Turbines

GE 7111EA

W 501 D5

ABB GT $11 \mathrm{~N}$
3600

3600

3600
$12.4 \quad 84620$

14.2106800

$12.4 \quad 81600$
10360

10100

10715
32.9

33.8

31.8

200 MW Cycle Available Turbines

$\begin{array}{llllll}\text { GE 7191F } & 3600 & 13.7 & 151340 & 9650 & 35.4 \\ \text { MW501F } & 3600 & 14.2 & 152300 & 9800 & 34.8\end{array}$

\subsubsection{NOx Formation}

The IGCC power plant will incorporate a fixed-bed, air-blown gasifier. The Lurgi Mark IV gasifier produces 4000-9000ppmv of NH3 in raw gas. [4] Ammonia in the gaseous state is very unstable and will reduce to harmless $\mathrm{N} 2$ in a reducing (oxygen deficient) environment, or partially to NOx in an oxidizing (oxygen rich) environment. Conventional gas turbine combustors operate in an oxidizing environment which results in 30-70\% conversion of ammonia to NOx. This would exceed emission control limits of 0.1 $\mathrm{lb} /$ million Btu which is the anticipated permissible level required by the year $2000 \mathrm{AD}$. NOx formation can be controlled by staged combustion. In the primary zone of staged combustion, a portion of the total air necessary for combustion is supplied to the fuel. This reducing environment promotes the formation of $\mathrm{N} 2$ rather than NOx. After the oxygen 
content of the primary zone is consumed, the products of incomplete combustion are mixed with additional air to complete the combustion process. This process reduces unstable ammonia to stable N2 before sufficient oxygen is present to form NOx. [5]

\subsubsection{Trace Metal Contaminants}

Trace metal contaminant levels in the hot-section components lead to corrosion, poor performance, and unscheduled maintenance. Specific contaminants that must be controlled are sodium and potassium. To prevent rapid deterioration of gas turbine components, strict limits are placed on these contaminants. Table 3 shows the limits placed on the gas turbines manufactured by the selected vendors.

\section{Table 3}

\begin{tabular}{|l|c|c|c|}
\hline & General Electric & Westinghouse & $\begin{array}{c}\text { Asea Brown } \\
\text { Boveri }\end{array}$ \\
\hline $\begin{array}{l}\text { Sodium plus Potassium } \\
\text { (ppm by weight) }\end{array}$ & 0.150 & 0.134 & 0.050 \\
\hline
\end{tabular}

To reach these levels, fines must be separated from the gas fuel stream prior to entry into the combustor section of the gas turbine. In addition to corrosion in the hot-gas components, high level of contaminants can cause hot-gas control valves to bind as experienced in the Cool Water Project. [6]

\subsubsection{Fuel Handling System}

The high temperature $(1000 \mathrm{~F}+)$ of raw gas entering the gas turbine will necessitate development of special fuel control valves. Previous project experience with IGCC systems have all entailed cooling the gas after exiting the gasifier. In these cases, the temperature of the fuel entering the gas turbine combustor rarely exceeded $400 \mathrm{~F}$. Thermal stress, erosion, and sticking are potential problems that must be addressed. Although current gas turbine control valves cannot handle high temperature gases, control valves will be well within state-of-the-art design within the schedule of commercial availability of this IGCC project. 


\subsubsection{Fuel Injectors}

Modifications must be made to the fuel injectors to prevent excessive combustion wall temperatures. The main combustibles of the synthetic gas are $\mathrm{CO}$ and $\mathrm{H} 2$. These two constituents have flame speeds 1.7 and 9.25 times faster than methane, respectively. These higher flame speeds greatly increase combustor wall temperatures. Flame speeds can be reduced by increasing the diameter of the gas injector openings. Optimization is required to determine the best orifice diameter to support stable combustion while minimizing combustor wall temperatures and control valve pressure differential. [7]

In addition to orifice diameter, the angle of the injector openings has an effect on combustion wall temperature. Excessive angles of injection will cause the gas to come close enough to the combustion wall to substantially increase metal temperatures.

\subsubsection{Compressor Surge}

With the low heating value of the coal derived gas, large mass and volume fuel flow rates are needed to supply the required heat input. Supplying this large quantity of fuel to a stanclard turbine cycle increases turbine expander mass flow, requiring an increase in combustion/expander inlet pressure. Compressor discharge pressure would have to rise to meet the increased combustor pressure. The compressor will accommodate increased discharge pressure at a decreased mass flow rate. There is a limit to the increased discharge pressure/decreased mass flow control range called surge. At this point, pulsations will occur within the compressor that will cause mechanical damage.

To avoid surge and maintain the combustor/expander at close to design pressures and mass flow rates, compressed air can be bled off the compressor discharge. This bleed air can be supplied to the fixed-bed gasifier. Surge within the compressor can be avoided if the mass flow throigh the expansion section is kept lower than 1.085 times the compressor mass flow for heavy-duty gas turbines and lower than 1.07 times the compressor mass flow for aero-derivative gas turbines. [8],[9] 


\subsubsection{Cycle Description}

Coal is supplied to a fixed-bed gasifier. The gasifying medium is air with a cooling medium injected into the gasifier to prevent the overheating of the grate and control peak combustion zone temperatures. Air used for gasification is extracted from the gas turbine at the compressor discharge. A boost compressor, placed between the compressor discharge and gasifier, will be used to overcome all pressure losses associated with the gasification process and to provide the needed fuel inlet pressure to the combustor. Raw gas exiting the gasifier contains $\mathrm{H} 2 \mathrm{~S} / \mathrm{COS}$ and particulates that must be removed before combustion in the gas turbine. Cyclones will be used to reduce particulates levels. A zinc ferrite desulfurization system (HGCU) is used to clean the gas to $10 \mathrm{ppmv}$ levels of $\mathrm{H} 2 \mathrm{~S} / \mathrm{COS}$. [10] The desulfurization unit consists of an absorber and regeneration vessel.

Regeneration produces a $\mathrm{SO} 2$ stream. This $\mathrm{SO} 2$ stream is passed through a sulfur recovery process (SRP) to make sulfuric acid, liquid SO2, or elemental sulfur. Clean gas leaving the zinc ferrite system is combusted in a gas turbine. The exhaust gas from the gas turbine passes through a heat recovery steam generator (HRSG) to produce steam for a steam turbine. (See Figure 1)

Table 4 shows the equipment needed for the three sizes of facilities.

\section{Table 4}

\begin{tabular}{|l|c|c|c|}
\hline & $50 \mathrm{MW}$ & $100 \mathrm{MW}$ & $200 \mathrm{MW}$ \\
\hline Gasifiers & 2 & 3 & 5 \\
\hline HGCU Systems & 1 & 2 & 4 \\
\hline SRP Units & 2 & 2 & 2 \\
\hline Gas Turbines & 1 & 1 & 1 \\
\hline Steam Turbines & 1 & 1 & 1 \\
\hline HRSG & 1 & 1 & 1 \\
\hline
\end{tabular}

2.3. Estimated Gas Turbine Performance

2.3.1 Characteristics of Fuel Supplied

The coal used for gasification is Ilinois No. 6. Air and steam inputs to the gasifier were assumed to be 2.12 and $0.836 \mathrm{lb}$ per $\mathrm{lb}$ of coal, respectively. Table 5 shows the coal analysis and gas produced in the fixed-bed gasifier. 


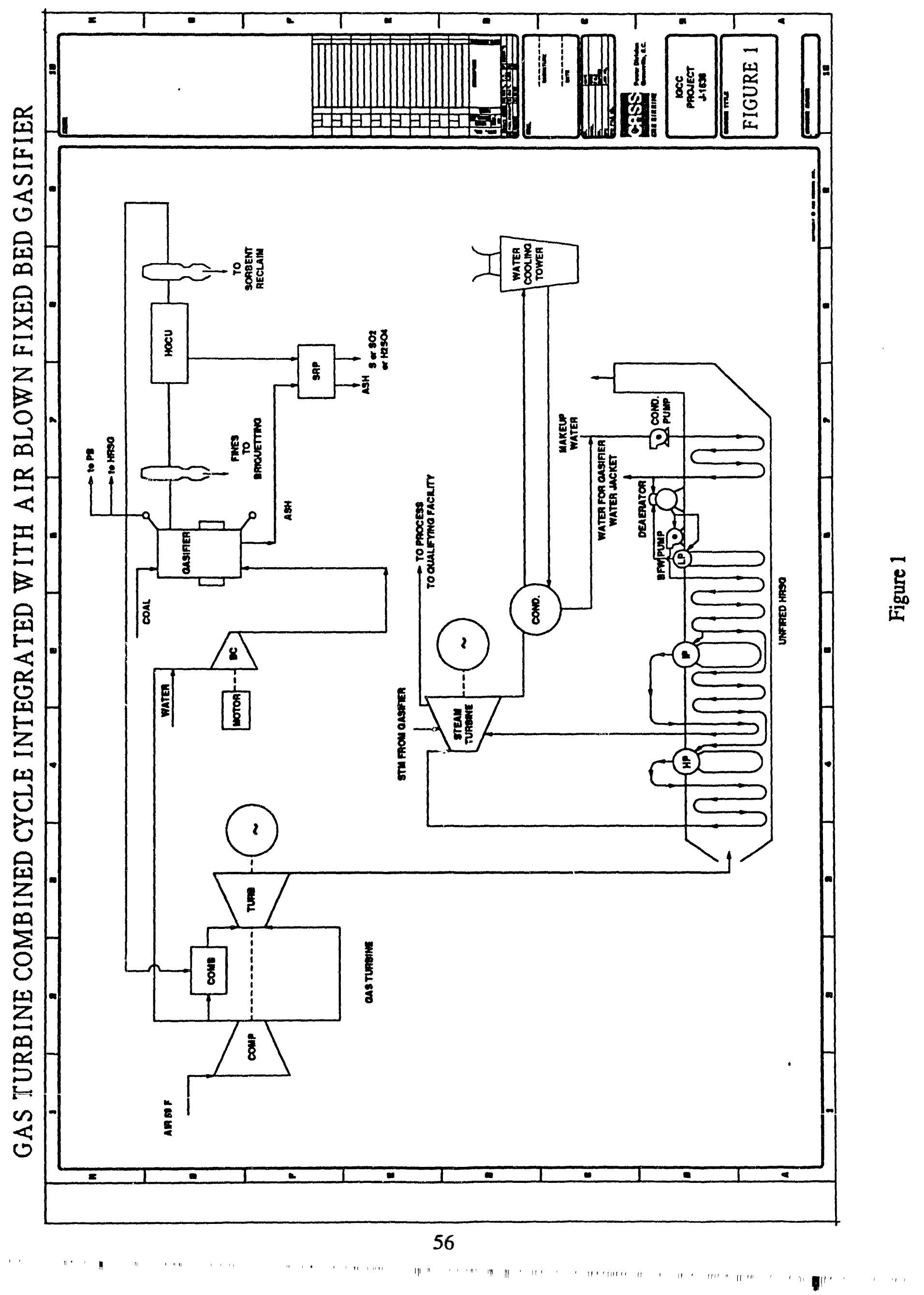


Table 5

\begin{tabular}{|c|c|c|c|}
\hline \multicolumn{2}{|c|}{ IIlinois No. 6 Coal } & \multicolumn{2}{|c|}{ Low-Btu Fuel } \\
\hline Constituents & Wt. \% & Constituents & Mol. \% \\
\hline $\begin{array}{l}\mathrm{C} \\
\mathrm{H} \\
\mathrm{O} \\
\mathrm{N} \\
\mathrm{S} \\
\mathrm{Cl}_{2} \\
\mathrm{H}_{2} \mathrm{O} \\
\mathrm{ASH} \\
\end{array}$ & $\begin{array}{r}57.47 \\
3.68 \\
5.84 \\
0.90 \\
4.04 \\
0.09 \\
12.00 \\
15.98 \\
\end{array}$ & $\begin{array}{l}\mathrm{OO} \\
\mathrm{H}_{2} \\
\mathrm{CH}_{4} \\
\mathrm{CnHm} \mathrm{H}_{2} \mathrm{~S}+\mathrm{COS} \\
\mathrm{N}_{2}+\mathrm{Ar} \\
\mathrm{CO}_{2} \\
\mathrm{H}_{2} \mathrm{O} \\
\end{array}$ & $\begin{array}{r}13.93 \\
20.03 \\
3.33 \\
0.08 \\
0.63 \\
38.51 \\
11.34 \\
12.15 \\
\end{array}$ \\
\hline \multicolumn{2}{|c|}{$\mathrm{HHV}=12,235 \mathrm{Btu} / \mathrm{lbm}$} & \multicolumn{2}{|c|}{$\begin{array}{c}\text { HHV/LHV }=2538 / 2221 \mathrm{Btu} / \mathrm{lbm} \\
\text { (HHV/LHV }=154 / 134 \mathrm{Btu} / \mathrm{scf}) \\
\text { (above heating values exclude } \\
\text { sensible heat) }\end{array}$} \\
\hline
\end{tabular}

Raw gas exits the gasifier at approximately $955 \mathrm{~F}$. Passing through the zinc ferrite desulfurization system, sulfur is removed to about $10 \mathrm{ppm} \mathrm{H} 2 \mathrm{~S} / \mathrm{COS}$ and the temperature of the gas is raised to $1020 \mathrm{~F}$. The gas entering the gas turbine combustor, including sensible heat, has a lower heating value of $2496 \mathrm{Btu} / \mathrm{lbm}$ (151 Btu/scf).

\section{Confidence in GTPro Tnrough Westinghouse Comparison}

The GTPro computer program was used to estimate system performance of all gas turbines selected. Confidence in GTPro's analysis was established by comparing predicted performance data received from Westinghouse against data computed by GTPro. Westinghouse evaluated three cases; the W 501 D5 gas turbine fueled by a low-Btu fuel at 20 F, 59 F, and 90 F. Table 6 lists performanze of the W 501 D5 gas turbine predicted by Westinghouse for all three cases along with the computed results by GTPro (the low Btu fuel is shown at the bottom of the table). Maximum variance between the Westinghouse and GTPro evaluations is $2.7 \%$, with a typical variance of $1.5 \%$. Predicted performance has not been verified by gas turbine manufacturers [11]. 
TABLE 6

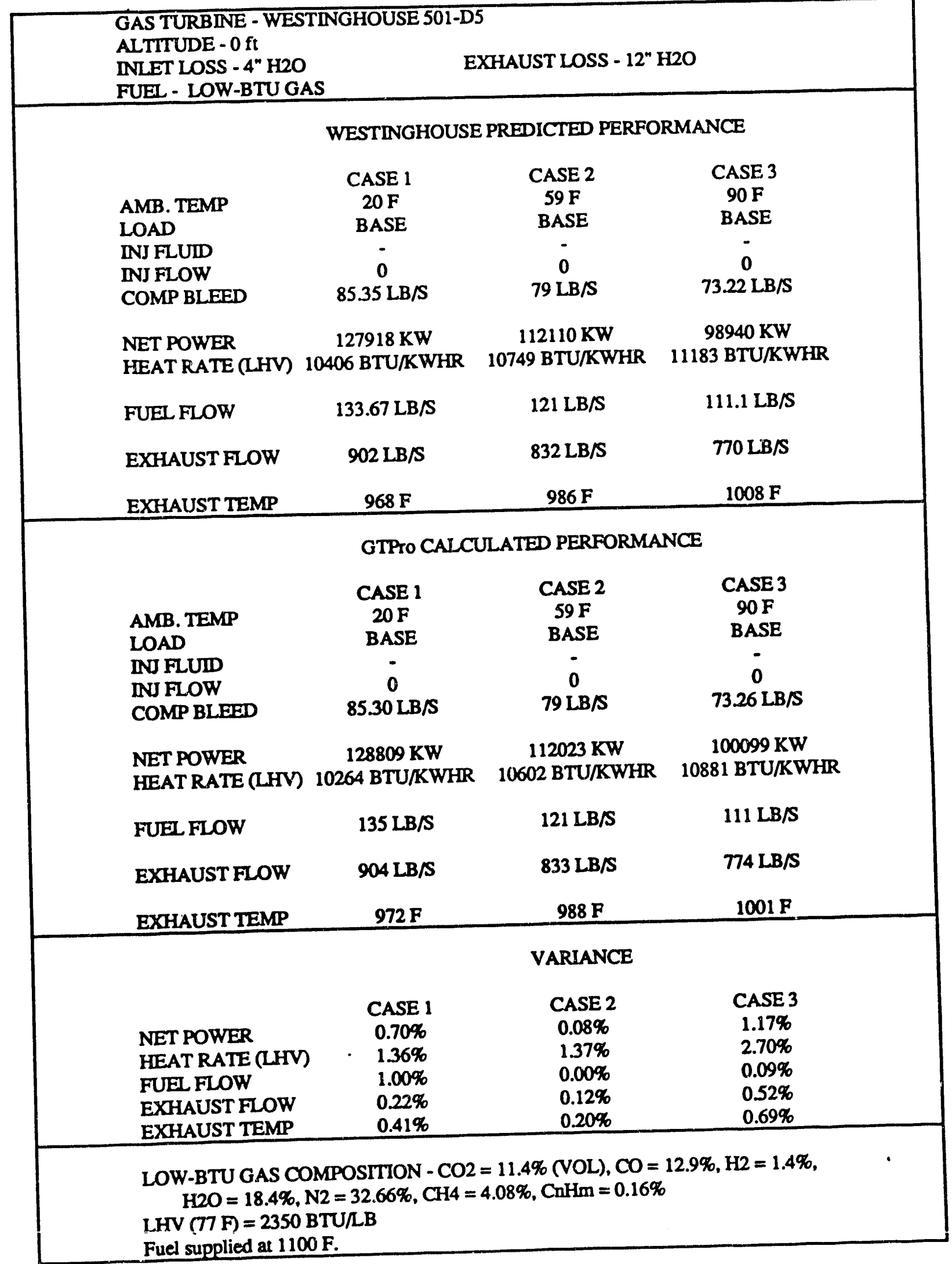




\subsection{3 $50 \mathrm{MW}$ Cycle}

Table 7 displays GTPro predicted performance for the GE LM/TG5000PC gas turbine fired on the fuel specified in Section 3.1. Ambient conditions at sea level are varied from $20 \mathrm{~F}$ to $90 \mathrm{~F}$. Aero-derivative engines use highly loaded compressors with small operating margins. With the increase in mass flow through the expansion section, the compressor quickly reaches its surge limit and the turbine inlet temperature must be reduced. This control function reduces fuel consunption, which reduces expander mass flow and required compressor discharge/combustor pressure.

\subsection{4 $100 \mathrm{MW}$ Cycle}

Table 8 displays GTPro predicted performance for the selected gas turbines for this cycle. By bleeding air from the compressor, all three turbines can burn the low-Btu fuel without derating the turbine inlet temperature or approaching the surge limit of the compressor. The W 501 D5 is slightly more efficient than the GE and ABB gas turbines. However, the exhaust temperature for the GE gas turbine is 17 degrees $F$ higher than the W 501 D5 and 26 degrees $F$ higher than the ABB GT $11 N$ at ISO conditions. This will cause the steam cycle efficiency to be the highest for the GE gas turbine. Therefore, combined cycle efficiency for both the Westinghouse and GE systems will be comparable, while the ABB combined cycle system will have the lowest efficiency.

\subsubsection{MW Cycle}

Table 9 displays GTPro predicted performance results for the GE 7191 F and the MW 501 F gas turbines. Both turbines can successfully operate on the low-Btu fuel by bleeding air from the compressor. The General Electric gas turbine is slightly more efficient than the Mitsubishi-Westinghouse gas turbine. Again, General Electric's exhaust temperature is 10 degrees $\mathrm{F}$ higher at ISO conditions which will increase combined cycle efficiency. 
TABLE 7 - 50 MW CYCLE

GAS TURBINE - GENERAL ELECTRIC LM/TG5000PC

ALTITUDE - $0 \mathrm{ft}$
INLET LOSS - 4" H2O
EXHAUST LOSS - 12" H2O

AMB. TEMP

REL. HUMIDITY

INLET FLOW

AIR BLEED

FUEL FLOW

TURBINE INLET TEMP

EXHAUST FLOW

EXHAUST TEMP

POWER GENERATED

Heat Rate HHV (1)

Efficiency HHV (1)

Coal Flow

Heat Rate HHV (2)

Efficiency HHV (2)
$20 \mathrm{~F}$

$60 \%$

$310.0 \mathrm{lb} / \mathrm{s}$

$25.9 \mathrm{lb} / \mathrm{s}$

$46.2 \mathrm{lb} / \mathrm{s}$

$2166 \mathrm{~F}$

$330.0 \mathrm{lb} / \mathrm{s}$

$801 \mathrm{~F}$

$44312 \mathrm{KW}$

10558 Btu/KWhr

$32.32 \%$

$12.2 \mathrm{lb} / \mathrm{s}$

$12124 \mathrm{Btw} / \mathrm{KWhr}$

$28.14 \%$
$59 \mathrm{~F}$

$60 \%$

$267.0 \mathrm{lb} / \mathrm{s}$

$22.3 \mathrm{lb} / \mathrm{s}$

$39.9 \mathrm{lb} / \mathrm{s}$

$2186 \mathrm{~F}$

$285.0 \mathrm{lb} / \mathrm{s}$

$849 \mathrm{~F}$

$36576 \mathrm{KW}$

11047 Btw/KWhr $30.89 \%$

$10.5 \mathrm{lb} / \mathrm{s}$

$12685 \mathrm{Btu} / \mathrm{KWhr}$

$26.90 \%$
$90 \mathrm{~F}$

$60 \%$

$234.0 \mathrm{lb} / \mathrm{s}$

$19.5 \mathrm{lb} / \mathrm{s}$

$34.8 \mathrm{lb} / \mathrm{s}$

$2181 \mathrm{~F}$

$250.0 \mathrm{lb} / \mathrm{s}$

$885 \mathrm{~F}$

$30489 \mathrm{KW}$

$11559 \mathrm{Bu} / \mathrm{KWhr}$ $29.52 \%$

$9.2 \mathrm{lb} / \mathrm{s}$

$13273 \mathrm{Btu} / \mathrm{KWhr}$ $25.71 \%$

(1) Based on cleaned fuel gas heating value

(2) Based on coal heating value

TABLE 8a - $100 \mathrm{MW}$ CYCLE

GAS TURBINE - GENERAL ELECTRIC GE 7111 EA

ALTITUDE - $0 \mathrm{ft}$

INLET LOSS - 4" $\mathrm{H} 2 \mathrm{O}$

AMB. TEMP

REL. HUMIDITY

INLET FLOW

AIR BLEED
FUEL FLOW
EXHAUST FLOW
EXHAUST TEMP

POWER GENERATED

Heat Rate HHV (1)

Efficiency HHV (1)

Coal Flow

Heat Rate HHV (2)

Efficiency HHV (2)
$20 \mathrm{~F}$

$60 \%$

$695.0 \mathrm{lb} / \mathrm{s}$

$66.6 \mathrm{lb} / \mathrm{s}$

$120.0 \mathrm{lb} / \mathrm{s}$

$748.0 \mathrm{lb} / \mathrm{s}$

$977 \mathrm{~F}$

$102844 \mathrm{KW}$

$11816 \mathrm{Btu} / \mathrm{KWhr}$

$28.88 \%$

$31.7 \mathrm{lb} / \mathrm{s}$

$13568 \mathrm{Btu} / \mathrm{KWhr}$

$25.15 \%$
FUEL - LOW-BTU GAS

EXHAUST LOSS - 12" H2O

$59 \mathrm{~F}$

$60 \%$

$641.0 \mathrm{lb} / \mathrm{s}$

$60.3 \mathrm{lb} / \mathrm{s}$

$108.0 \mathrm{lb} / \mathrm{s}$

$688.0 \mathrm{lb} / \mathrm{s}$

$1001 \mathrm{~F}$

$89954 \mathrm{KW}$

$12158 \mathrm{Btu} / \mathrm{KWhr}$ $28.06 \%$

$28.5 \mathrm{lb} / \mathrm{s}$

$13961 \mathrm{Btu} / \mathrm{KWhr}$

$24.44 \%$
$90 \mathrm{~F}$

$60 \%$

$595.0 \mathrm{lb} / \mathrm{s}$

$55.8 \mathrm{lb} / \mathrm{s}$

$99.7 \mathrm{Ib} / \mathrm{s}$

$639.0 \mathrm{lb} / \mathrm{s}$

$1018 \mathrm{~F}$

$81879 \mathrm{KW}$

$12331 \mathrm{Btu} / \mathrm{KWhr}$ $27.67 \%$

$26.3 \mathrm{lb} / \mathrm{s}$ $14159 \mathrm{Btu} / \mathrm{KWhr}$ $24.10 \%$

(i) Bused on clcanted fuel gas heating yalue

(2) Based on coal heating value 
TABLE 8b - 100 MW CYCLE

GAS TURBINE - WESTINGHOUSE 501-D5

ALTITUDE - $0 \mathrm{ft}$

FUEL - LOW-BTU GAS

INLET LOSS - 4" H2O

EXHAUST LOSS - 12" $\mathrm{H} 2 \mathrm{O}$

$\begin{array}{lr}\text { AMB. TEMP } & \\ \text { REL. HUMIDITY } & 60 \\ \text { INLET FLOW } & \\ \text { AIR BLEED } & \\ \text { FUEL FLOW } & \\ \text { EXHAUST FLOW } & 143 . \\ \text { EXHAUST TEMP } & \\ \text { POWER GENERATED } & 920.0 \\ \text { Heat Rate HHV (1) } & 969 \\ \text { Efficiency HHV (1) } & 131307 \\ \text { Coal Flow } & 11491 \\ \text { Heat Rate HHV (2) } \\ \text { Efficiency HHV (2) } \\ \begin{array}{l}\text { (1) Based on cleaned fuel gas heating value } \\ \text { (2) Based on coal heating value }\end{array}\end{array}$

$20 \mathrm{~F}$

$60 \%$

$855.0 \mathrm{lb} / \mathrm{s}$

$83.3 \mathrm{lb} / \mathrm{s}$

$149.0 \mathrm{lb} / \mathrm{s}$

$920.0 \mathrm{lb} / \mathrm{s}$

$969 \mathrm{~F}$

$131307 \mathrm{KW}$

$11491 \mathrm{Btu} / \mathrm{KWhr}$ $29.69 \%$

$39.3 \mathrm{lb} / \mathrm{s}$

$3195 \mathrm{Btu} / \mathrm{KWhr}$

$25.86 \%$
$59 \mathrm{~F}$

$60 \%$

$791.0 \mathrm{db} / \mathrm{s}$

$75.0 \mathrm{lb} / \mathrm{s}$

$134.0 \mathrm{lb} / \mathrm{s}$

$850.0 \mathrm{lb} / \mathrm{s}$

$985 \mathrm{~F}$

$114726 \mathrm{KW}$

$11828 \mathrm{Btu} / \mathrm{KWhr}$ $28.85 \%$

$35.4 \mathrm{lb} / \mathrm{s}$

$13582 \mathrm{Btu} / \mathrm{KWhr}$

$25.12 \%$
$90 \mathrm{~F}$

$60 \%$

$737.0 \mathrm{lb} / \mathrm{s}$

$68.8 \mathrm{lb} / \mathrm{s}$

$123.0 \mathrm{Jb} / \mathrm{s}$

$791.0 \mathrm{lb} / \mathrm{s}$

$998 \mathrm{~F}$

$103144 \mathrm{KW}$

$12076 \mathrm{Bru} / \mathrm{KWhr}$ $28.26 \%$

$32.5 \mathrm{lb} / \mathrm{s}$ $13867 \mathrm{Btu} / \mathrm{KWhr}$ $24.61 \%$

TABLE 8c - 100 MW CYCLE

GAS TURBINE - ASEA BROWN BOVERI GT $11 N$

ALTTTUDE - $0 \mathrm{ft}$ INLET LOSS - 4" H2O

AMB. TEMP

REL. HUMIDITY

INLET FLOW

AIR BLEED

FUEL FLOW

EXHAUST FLOW

EXHAUST TEMP

POWER GENERATED

Heat Rate HHV (1)

Efficiency HHV (1)

Coal Flow

Heat Rate HHV (2)

Efficiency HHV (2)

FUEL - LOW-BTU GAS

EXHAUST LOSS - 12" H2O
$20 \mathrm{~F}$

$60 \%$

$719.0 \mathrm{lb} / \mathrm{s}$

$66.0 \mathrm{lb} / \mathrm{s}$

$118.0 \mathrm{lb} / \mathrm{s}$

$770.0 \mathrm{lb} / \mathrm{s}$

$964 \mathrm{~F}$

$97551 \mathrm{KW}$

$12250 \mathrm{Btu} / \mathrm{KWhr}$ $27.86 \%$

$31.2 \mathrm{lb} / \mathrm{s}$ $14066 \mathrm{Btu} / \mathrm{KWhr}$ $24.26 \%$
$60.3 \mathrm{lb} / \mathrm{s}$
$59 \mathrm{~F}$

$60 \%$

$678.0 \mathrm{lb} / \mathrm{s}$

$108.0 \mathrm{lb} / \mathrm{s}$

$726.0 \mathrm{lb} / \mathrm{s}$

$976 \mathrm{~F}$

$86460 \mathrm{KW}$

$12650 \mathrm{Btu} / \mathrm{KWhr}$ $26.97 \%$

$28.5 \mathrm{lb} / \mathrm{s}$

$14525 \mathrm{Btu} / \mathrm{KWhr}$ $23.49 \%$
$90 \mathrm{~F}$

$60 \%$

$637.0 \mathrm{lb} / \mathrm{s}$

$56.0 \mathrm{lb} / \mathrm{s}$

$99.8 \mathrm{lb} / \mathrm{s}$

$681.0 \mathrm{lb} / \mathrm{s}$

$993 \mathrm{~F}$

$77704 \mathrm{KW}$

$13006 \mathrm{Bru} / \mathrm{KWhr}$ $26.23 \%$

$26.4 \mathrm{lb} / \mathrm{s}$ $14935 \mathrm{Btu} / \mathrm{KWhr}$ $22.85 \%$

(1) Based on cleaned fuel gas heating value

(2) Based on coal heating value 


\subsection{Issues Affecting Turbine Performance}

\subsubsection{Coal Quality}

The Free Swelling Index and ash fusion characteristics of the coal vary the raw gas quantity from the gasifier. Therefore, once a gasifier has been selected to process a selected coal, variations in the coal might reduce the gas output. This will result in reduced power production.

\subsubsection{Gasifier Cooling}

Steam is injected into the gasifier to cool the grate and control peak combustion zone temperatures. However, as the amount of steam is increased, the heating value of the exiting gas decreases by dilution. This results in large quantities of fuel needed for combustion in the gas turbine. The compressor will reach the surge limit with excessive amounts of steam injection into the gasifier.

Alternative methods of cooling the gasifier grate and limiting peak gasifier combustion zone temperature to avoid ash melting are being developed. One such method is the use of atomized water spray between the turbine compressor bleed and the booster compressor. Such a scheme serves to cool the gasifier air bleed stream by water evaporation (in lieu of an intercooler). Ultimately, this also serves to cool the gasifier grate and lower peak gasification temperature with minimum addition of mass to the low Btu gas stream. Using water instead of steam increases the heating value of the fuel, leaving the gasifier by approximately $20 \%$. Therefore, fuel flow requirements for the gas turbine will decrease and compressor surge avoided. 
TABLE 9a - 200 MW CYCLE

GAS TURBINE - GENERAL ELECTRIC GE 7191 F

ALTITUDE - $0 \mathrm{ft}$

FUEL - LOW-BTU GAS

INLET LOSS - 4" H2O

EXHAUST LOSS - 12" $\mathrm{H} 2 \mathrm{O}$

AMB. TEMP

REL. HUMIDITY

INLET FLOW

AIR BLEED

FUEL FLOW

EXHAUST FLOW

EXHAUST TEMP

POWER GENERATED

Heat Rate HHV (1)

Efficiency HHV (1)

Coal Flow

Heat Rate HHV (2)

Efficiency HHV (2)
$20 \mathrm{~F}$

$60 \%$

$987.0 \mathrm{lb} / \mathrm{s}$

$110.8 \mathrm{lb} / \mathrm{s}$

$198.0 \mathrm{lb} / \mathrm{s}$

$1074.0 \mathrm{lb} / \mathrm{s}$

$1073 \mathrm{~F}$

$180379 \mathrm{KW}$

$11116 \mathrm{Btu} / \mathrm{KWhr}$

$30.70 \%$

$52.3 \mathrm{lb} / \mathrm{s}$
$12764 \mathrm{Btu} / \mathrm{KWhr}$
$26.73 \%$

$59 \mathrm{~F}$

$60 \%$

$921.0 \mathrm{lb} / \mathrm{s}$

$102.0 \mathrm{lb} / \mathrm{s}$

$183.0 \mathrm{lb} / \mathrm{s}$

$1002.0 \mathrm{lb} / \mathrm{s}$

$1102 \mathrm{~F}$

$161714 \mathrm{KW}$

$11460 \mathrm{Btw} / \mathrm{KWhr}$ $29.78 \%$

$48.3 \mathrm{lb} / \mathrm{s}$

$13159 \mathrm{Btu} / \mathrm{KWhr}$ $25.93 \%$
$90 \mathrm{~F}$

$60 \%$

$859.0 \mathrm{Jb} / \mathrm{s}$

$95.0 \mathrm{lb} / \mathrm{s}$

$170.0 \mathrm{lb} / \mathrm{s}$

$935.0 \mathrm{lb} / \mathrm{s}$

$1129 \mathrm{~F}$

$147509 \mathrm{KW}$

$11671 \mathrm{Btu} / \mathrm{KWhr}$ $29.24 \%$

$44.9 \mathrm{lb} / \mathrm{s}$ $13402 \mathrm{Bru} / \mathrm{KWhr}$ $25.46 \%$

(1) Based on cleaned fuel gas heating value

(2) Based on coal heating value

\section{TABLE 9b - 200 MW CYCLE}

GAS TURBINE - MITSUBISHI-WESTINGHOUSE 501-F ALTTTUDE - $0 \mathrm{ft}$ INLET LOSS - 4" H2O

FUEL - LOW-BTU GAS

EXHAUST LOSS - 12" H2O

AMB. TEMP

REL. HUMIDITY

INLET FLOW

AIR BLEED

FUEL FLOW

EXHAUST FLOW

EXHAUST TEMP

POWER GENERATED

Heat Rate HHV (1)

Efficiency HHV (1)

Coal Flow

Heat Rate HHV (2)

Efficiency HHV (2)
$20 \mathrm{~F}$

$60 \%$

$1016.0 \mathrm{lb} / \mathrm{s}$

$117.1 \mathrm{lb} / \mathrm{s}$

$208.0 \mathrm{lb} / \mathrm{s}$

$1107.0 \mathrm{lb} / \mathrm{s}$

$1075 \mathrm{~F}$

$188682 \mathrm{KW}$

$11164 \mathrm{Btu} / \mathrm{KWhr}$ $30.57 \%$

$54.9 \mathrm{lb} / \mathrm{s}$

$12819 \mathrm{Btu} / \mathrm{KWhr}$

$26.60 \%$
$59 \mathrm{~F}$

$60 \%$

$941.0 \mathrm{lb} / \mathrm{s}$

$105.7 \mathrm{lb} / \mathrm{s}$

$188.0 \mathrm{lb} / \mathrm{s}$

$1023.0 \mathrm{lb} / \mathrm{s}$

$1092 \mathrm{~F}$

$166235 \mathrm{KW}$

11453 Btu/KWhr $29.79 \%$

$49.6 \mathrm{lb} / \mathrm{s}$

$13151 \mathrm{Btu} / \mathrm{KWhr}$ $25.95 \%$
$90 \mathrm{~F}$

$60 \%$

$876.0 \mathrm{lb} / \mathrm{s}$

$97.4 \mathrm{lb} / \mathrm{s}$

$174.0 \mathrm{lb} / \mathrm{s}$

$953.0 \mathrm{lb} / \mathrm{s}$

$1108 \mathrm{~F}$

$150272 \mathrm{KW}$

$11726 \mathrm{Bra} / \mathrm{KWhr}$ $29.10 \%$

$45.9 \mathrm{lb} / \mathrm{s}$ $13465 \mathrm{Btu} / \mathrm{KWhr}$ $25.34 \%$

(1) Based on cleaned fuel gas heating value

(2) Based on coal heating value 


\subsubsection{Gas Turbine Compressor Surge}

Surge occurs when compressor discharge pressure rises and discharge flow is reduced beyond the design margin. Compressor discharge pressure is related to combustor/expander mass flow rates. This establishes an upper limit on fuel gas flow.

Efforts to minimize fuel mass flow (water injection versus steam injection to gasifier) will reduce surge control requirements.

\subsubsection{Combustion Turbine Inlet Temperatures}

Latest advancements in metallurgy and air cooling techniques have allowed turbine inlet temperatures to rise to $2300 \mathrm{~F}$. Single crystal casting techniques and new cobalt-based alloys point toward higher firing temperatures in the future. An increase of $100 \mathrm{~F}$ in firing temperature relates to a 10 to $13 \%$ increase in power output and 2 to $4 \%$ improvement in simple cycle efficiency. [11]

It may be difficult to reach these higher turbine inlet temperatures with an existing aeroderivative gas turbine burning low-Btu fuel. The increased mass flow through the expansion section of the turbine causes shaft speeds and pressures to rise quickly in multishaft machines. As a result, turbine inlet temperatures may have to be decreased to control overall gas turbine performance.

\subsubsection{Fuel Inlet Pressure}

Some manufacturer's requirements indicate a need for a pressure drop across the fuel control valve of up to $75 \mathrm{psi}$. The operating pressure of the gasifier will be increased over the compressor discharge pressure by the amount needed to overcome system pressure losses and pressure drops across the fuel valves. Minimization of fucl valve pressure losses decreases gasification pressure and therefore, air booster compressor power consumption. 
There exists significant concem (Appendix B) as to the fate of volatilized alkali between the coal gasifier and the turbine combustor. If significant fractions of alkali reach the turbine combustor and form sodium sulfate, premature turbine expander blaas corrosion may be expected.

\subsubsection{NOx Emissions}

The combination of rich/lean combustion at the turbine combustor combined with selective catalytic reduction (SCR) is believed to be sufficient to achieve the goal of $0.1 \mathrm{lb} / \mathrm{MBtu}$ NOx emission rate.

\section{REFERENCES}

1. GTPro is proprietary program of Thermoflow, Inc.

2. Baily, F.G., Rendine, A.P., Robbins, K.E., "Steam Turbines for STAG CombinedCycle Power Systems", GE Company, Schenectady, New York, 1989, p.2-3.

3. Foster Wheeler and Westinghouse presentation to METC on 10/24/89.

4. CRS Sirrine, "Status of Low BTU Gasification Systems for a Standardicied IGCC Gasifier", CRS Sirrine, Greenville, SC, 1990, p.8.

5. Singer, Joseph G., ed.,Combustion - Fossil Power Systems, Combustion Engineering, Windsor, Connecticut, 3rd edition, 1981, p. 4-33-4-36.

6. Personal Communication with GE Industrial \& Power Systems, August 14, 1989.

7. Morrison, E.M., Pillsbury, P.W., "Coal Generated Synthetic Gas Operating Experience with Two 100 MW-Class Combustion Turbines", p. 3-5.

8. ABB Correspondence, April 23, 1990.

9. Smith, S.S., Brooks, F.J., "GE LM5000 Aircraft-Derivative Gas Turbine System", GE Company, Schenectady, New York, 1989, p. 11-12.

10. Ghate, M.R., Markel, Jr., K.E., Jarr, L.A., Bossart, S.J., Proceedings of the Seventh Annual Gasification and Gas Stream Cleanup Systems Contractors Review Meeting, Volume II, p.680.

11. Direct Communication with Westinghouse, February 21, 1990

12. Schilke, P.W., Foster, A.D., Pepe, J.J., "Advanced Gas Turbine Materials and Coatings", GE Company, Schenectady, New York, 1989, p. 3-8. 


\title{
Gasifier Design Modifications Required to Accommodate High Free Swelling Coals
}

\section{Section 3}

January 1991

Work Performed Under Contract No. DE-AC21-89MC26291

\author{
For \\ U.S. Department of Energy \\ Office of Fossil Energy \\ Morgantown Energy Technology Center \\ P.O. Box 880 \\ Morgantown, West Virginia 26507-0880 \\ B y \\ CRS SIRRINE, INC. \\ Power Division \\ P.O. Box 5456 \\ 1041 East Butler Road \\ Greenville, South Carolina 29606-5456
}




\subsection{Summary}

This specific section is intended to evaluate advantages/disadvantages of candidate coal gasifiers matched with combustion turbine/HGCU modules. It also provides for the development and expected performance characteristics of selected advanced coal gasification machines as required to accommodate program objectives. Included is the assimilation of empirical data and industry experience describing optimized combinations of air-blown Fixed Bed Gasifier/HGCU/Combustion Turbine combinations.

The data reviewed was developed from the principal investigator's experience in the design, construction, and operation of air-blown, fixed-bed coal gasifier, stoker, pulverized and fluidized coal combustion systems. In addition, data developed by the Department of Energy's Morgantown Energy Technology Center (METC), General Electric (GE), the Lurgi Corporation, GT Pro and MESA Computer Programs was utilized in the assessment of the status of air-blown, fixed-bed coal gasifiers as applied to standardized IGCC systems.

Although historical information reveals that maximum coal inputs (hence raw gas outputs) to fixed bed systems vary significantly due to wide ranges in coal reactivity, caking and ash fusion characteristics, the selection of standardized modular components assumes the successful near term development of air-blown, fixed-bed gasifiers capable of operation without capacity reduction due to coal quality changes over the range of US coals contemplated.

It has been determined that the formation of stickey tars and asphaltines during the devolitization process is the main cause of subsequent agglomeration leading to channeling, reduced coal/air/steam reactions, and hence output capacity reductions. Two approaches to dealing with this problem are postulated herein. The first provides for a mechanical means of breaking up agglomerates as and once they have formed. The other is aimed at preventing the inception of agglomeration. 


\subsection{Coal Gasifier Selections}

\subsubsection{Overview Descriptions of Candidate Coal Gasifiers}

In order to better understand the effects of various parameters upon coal gasifier performance, an overview of selected available coal gasifiers [1][2] was conducted (Table 1). The results of that overview are presented in the following sections.

Table 1

Generic Gasifier Features

Gasifier

Air-blown, Fixed-bed, Dry-ash Bottom

Lurgi

Riley Morgan

Wellman Galusha

Woodall-Duckham

Kohlegas Nordithein

GE

METC

\section{Features}

300 psi Operating Experience Mature Mechanical Design Commercially Available

Air-blown Experience on US Coals Water Cooled Stirrer Experienc:

Mature Mechanical Design

Two Stage Mature Mechanical Design

Internal Recycle of Top Gas

Air-blown Experience on US Coals

Air-blown Experience on US Coals Water Cooled Stirrer Experience High Pressure Operating Experience Grate Accomodates Clinkers

Air-blown, Fixed-bed \& Entrained-bed, Slagging Bottom

British Gas Lurgi

Voest-Alpine Gasification Reactor

National Coal Board

Py-Gas Coal Gasifier at Full Capacity
Capable of Handling Fines Produces Benign Ash

Capable of Handling Fines Produces Benign Ash

Capable of Handling Fines Produces Benign Ash

Accepts High Free Swelling Coals Accepts Coal Fines Cracks Tars Condenses Volatilized Alkali Eliminates Coal Feed Lock Hopper Losses 
The concept of modular standardized plants results in the anticipation of the utilization of either the proper number of Lurgi or METC air-blown fixed bed coal gasifiers sized for the specific coal characteristic analysis under consideration (Figure 1), or the anticipation of an alternate air-blown, fixed-bed coal gasifier capable of operating without capacity limitations over the entire range of coal characteristics contemplated within this study. Four hot gas cleanup unit (HGCU) absorber modules and a four HGCU regenerator modules sized for shop fabrication and truck delivery (approximately $13 \mathrm{ft}$. diameter) are anticipated to be of sufficient capacity for the $200 \mathrm{MW}$ nominal plant capacity (Figure 2). Two direct sulfur dioxide recovery process (DSO2RP) packed column vessels, steaming tower and drying tower in series including heat exchangers for sulfur dioxide condensation are anticipated to be sufficient for $99+\%$ sulfur removal.

\subsubsection{Air-blown, Fixed-bed, Dry-ash Bottom}

Several air-blown, fixed bed, dry ash bottom gasifier candidates were considered. These include Lurgi, Riley Morgan, Wellman Galusha, Woodall Duckham/GI, Kohlegas Nordrhein (KGN), GE, and METC. These coal gasification devices are mature mechanical designs applicable to limited capacity outputs [3]. The Lurgi (Figure 3) and METC (Figure 4) designs come closest to meeting the operational constraints imposed by the IGCC concepts of this study. Both are high operating pressure designs which have acknowledged limited air-blown experience, but which have been demonstrated on a wide variety of US coals. The Lurgi gasifier output is suspect on high free swelling coals [3][4][5], while the METC gasifier requires scaleup of at least 15 to 1 on coal throughput to be considered for cogeneration applications. Its ability to gasify high free swelling coals is contingent on its internal stirrer mechanism's ability to break up clinkers into manageable sizes and to control channeling during the agglomeration process.

\subsubsection{Air-blown, Fixed \& Entrained-bed, Slagging Bottom}

Several air-blown fixed and entrained bed, slagging bottom-ash gasifier candidates were considered. These include British Gas Lurgi (BGL), Voest-Alpine Gasification Reactor, National Coal Board (NCB-CURL) fixed bed reactors, and Texaco, Shell, and Dow entrained bed reactors.. These coal gasification devices are also mature mechanical designs applicable to a limited coal inorganic fraction characteristic range 


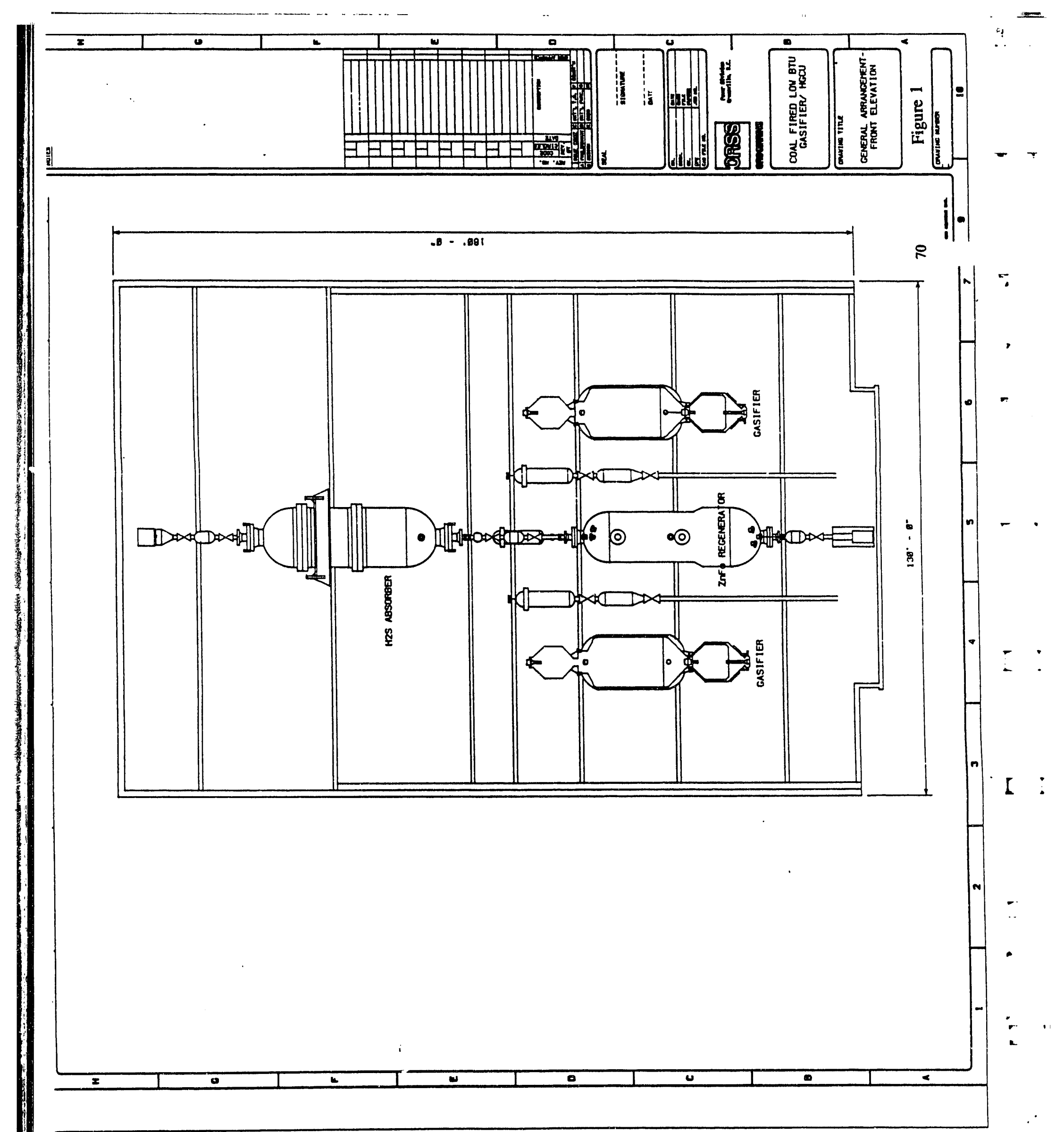




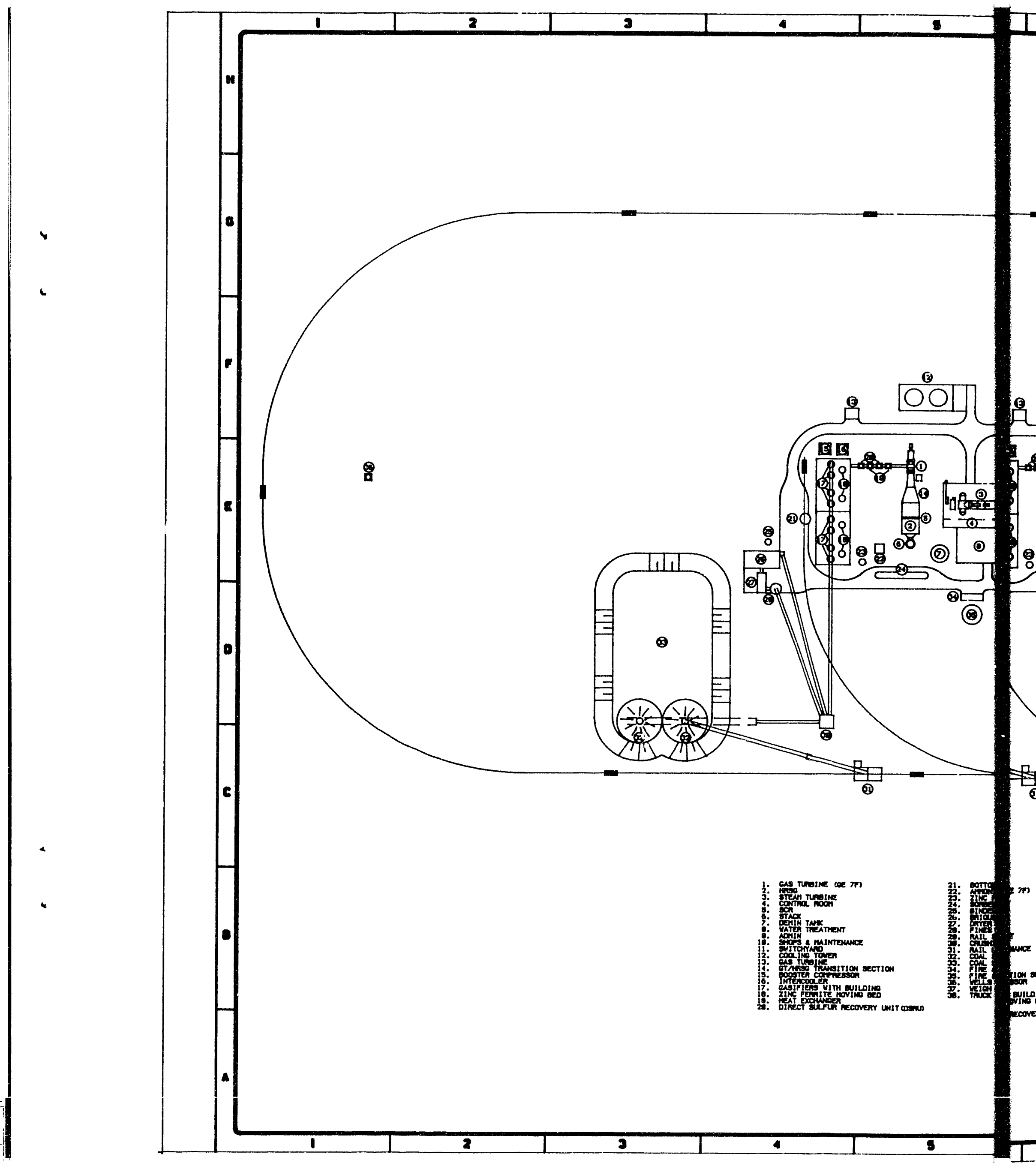




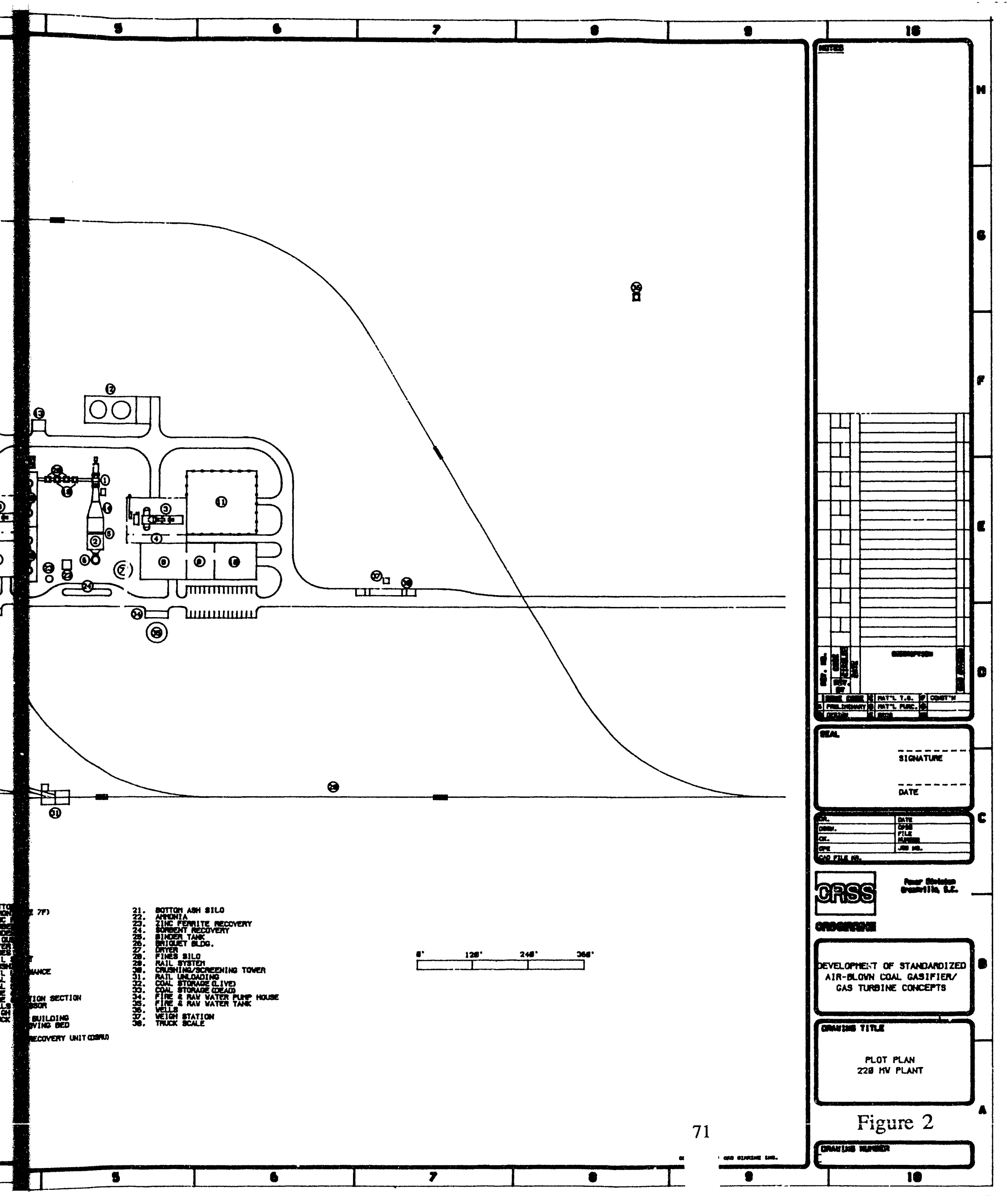




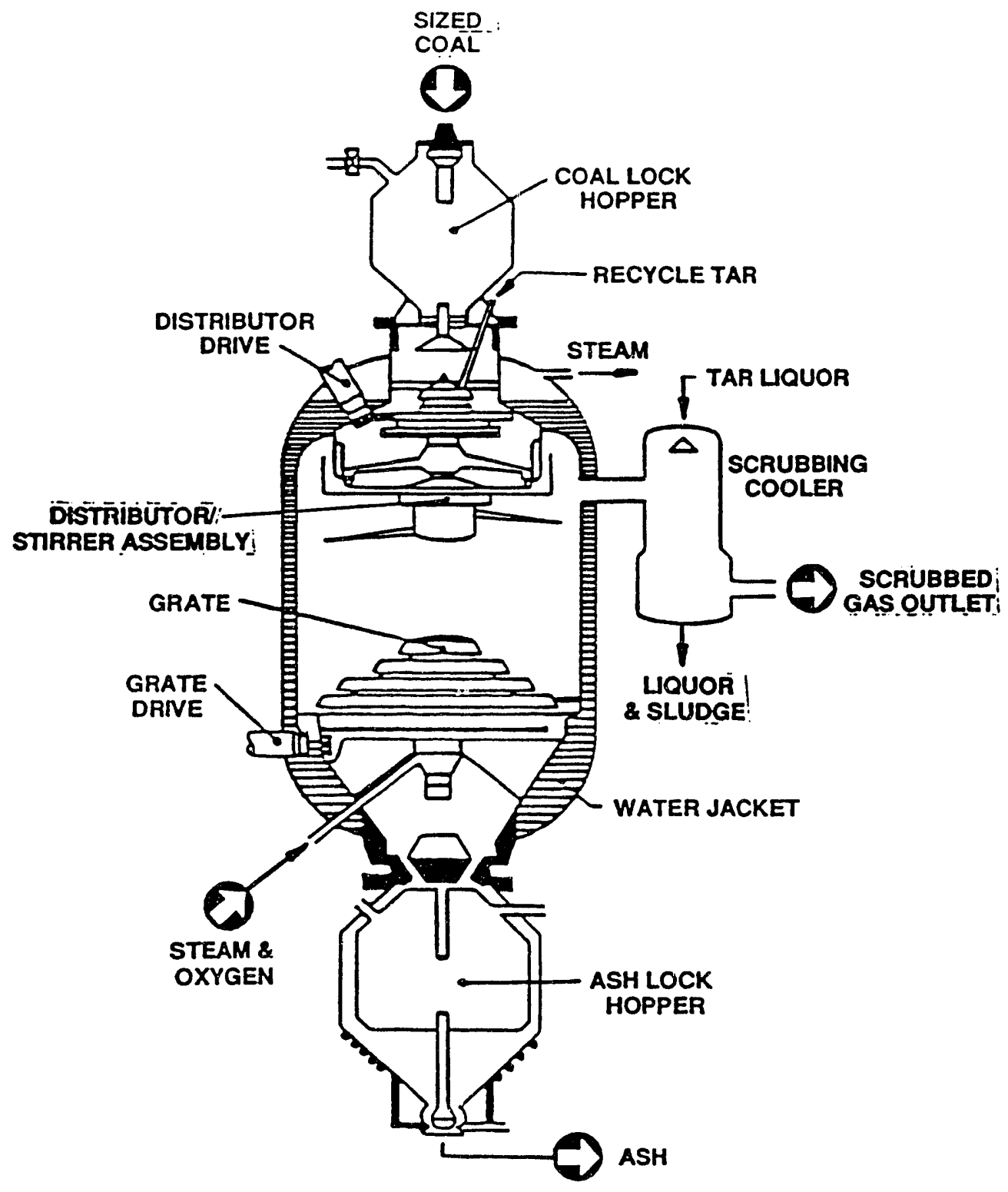

Lurgi Pressure Gasifier

Figure 3 


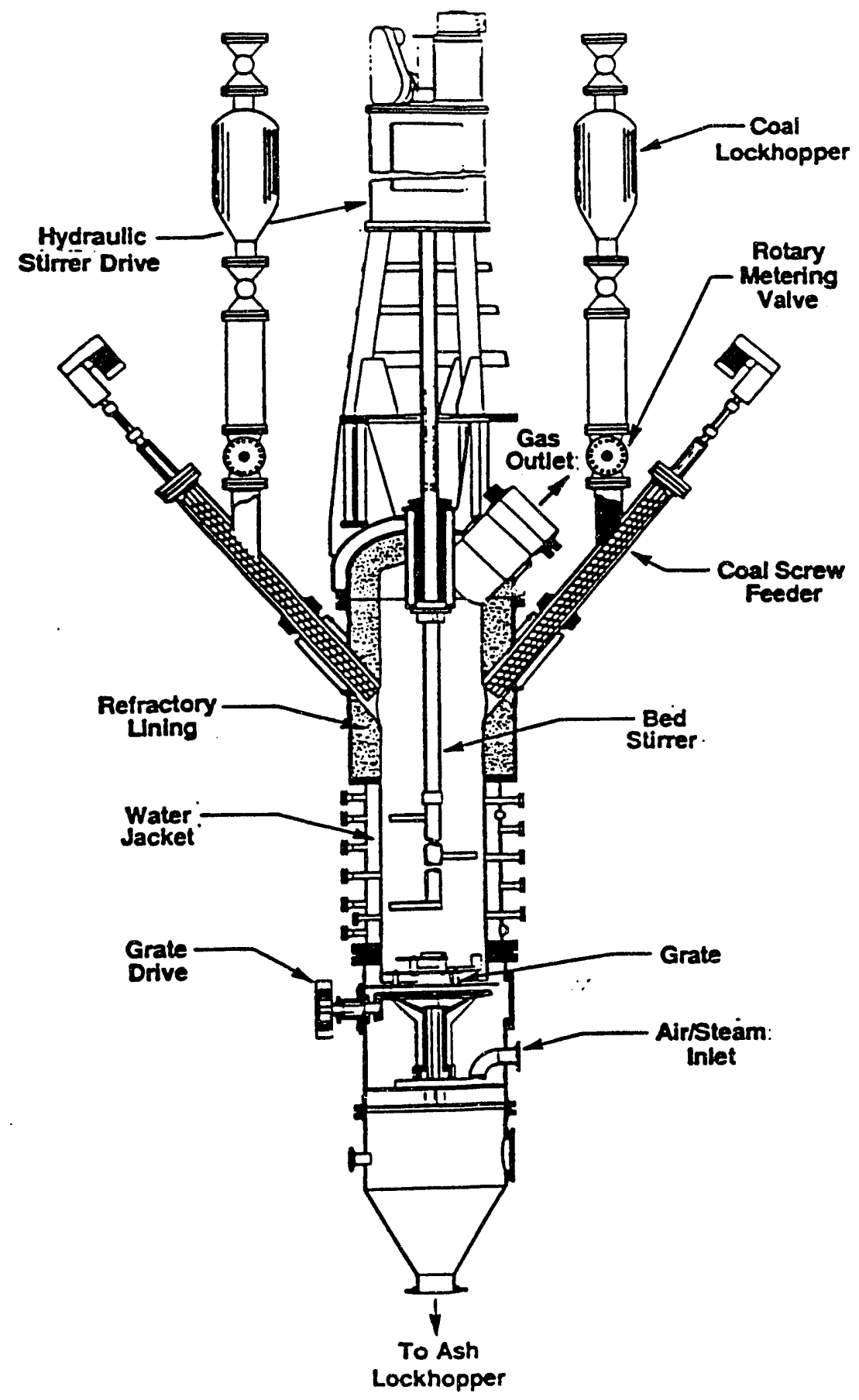

Sectional View of Current METC Fixed-Bed Gasifier Figure 4 
when air-blown. The anticipated draw back of these candidates stems from the historical limits of similar applications of utility sized slagging pulverized coal fired boilers designed for molten ash tapping removal. Both the B\&W Cyclone and the Riley Wet Bottom Turbo Furnace (Figure 5) designs saw very limited application [6] due to the limited availability of coals in the USA whose ash fusion temperature ranges and theoretical T-250 poise viscosity characteristics were low enough to avoid molten slag tapping difficulties. In many cases fluxing agents had to be introduced into the firing chamber of these utility applications to maintain molten slag conditions and avoid freezing of the slag prior to tapping.

A second concern in the consideration of molten bottom gasifiers is the expectation of considerably greater volatilized alkali [7][8] generation due to their comparatively higher gasification operating temperatures. Data reviewed (Figure 6) shows as much as three orders of magnitude greater amounts of volatilized alkali is associated with these higher operating temperature processes than for the lower operating temperature fixed-bed, dry-bottom gasifiers.

For these reasons, this study will not give further consideration to the entrained or fixed bed slagging type of gasifier.

\subsubsection{Py-Gas Coal Gasifier}

Consistent with the objectives of this study, a new concept in coal gasification design is presented herein. While the approach anticipated in paragraph 3.1 above deals with agglomeration and clinkering (which lead to channeling and capacity curtailment ) after the fact, the approach of the PyGas (Figure 7) concept is to avoid (by design) the conditions within the gasifier which promote or initiate agglomeration and clinkering. 


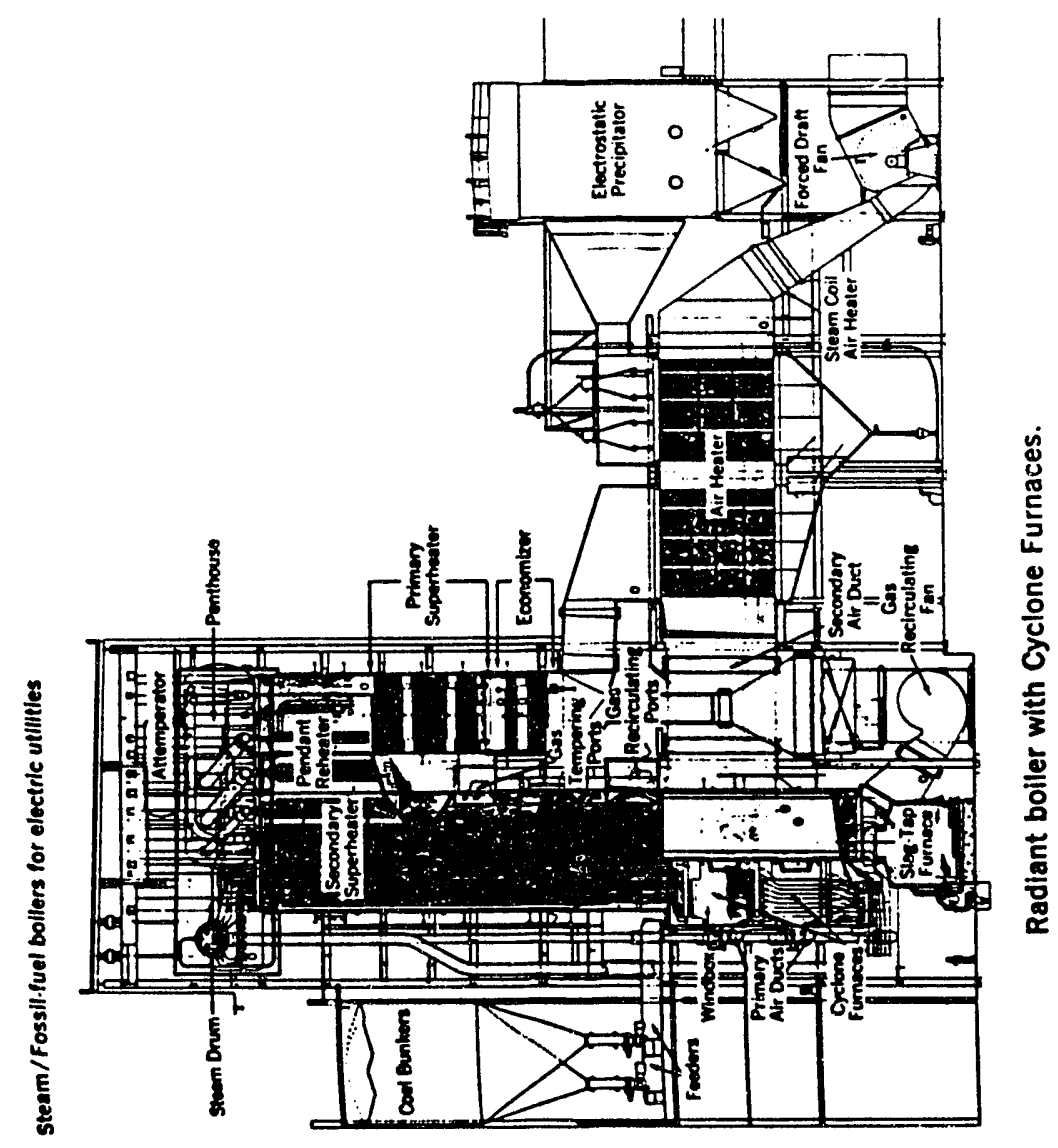

先

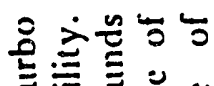

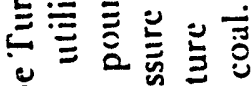

次 $=0$

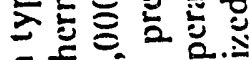

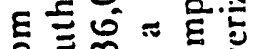

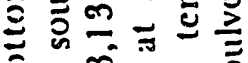

ڤั

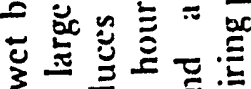

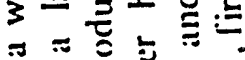

$\because=\overline{2} x$

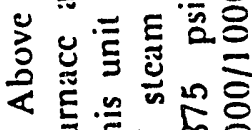

돈. 


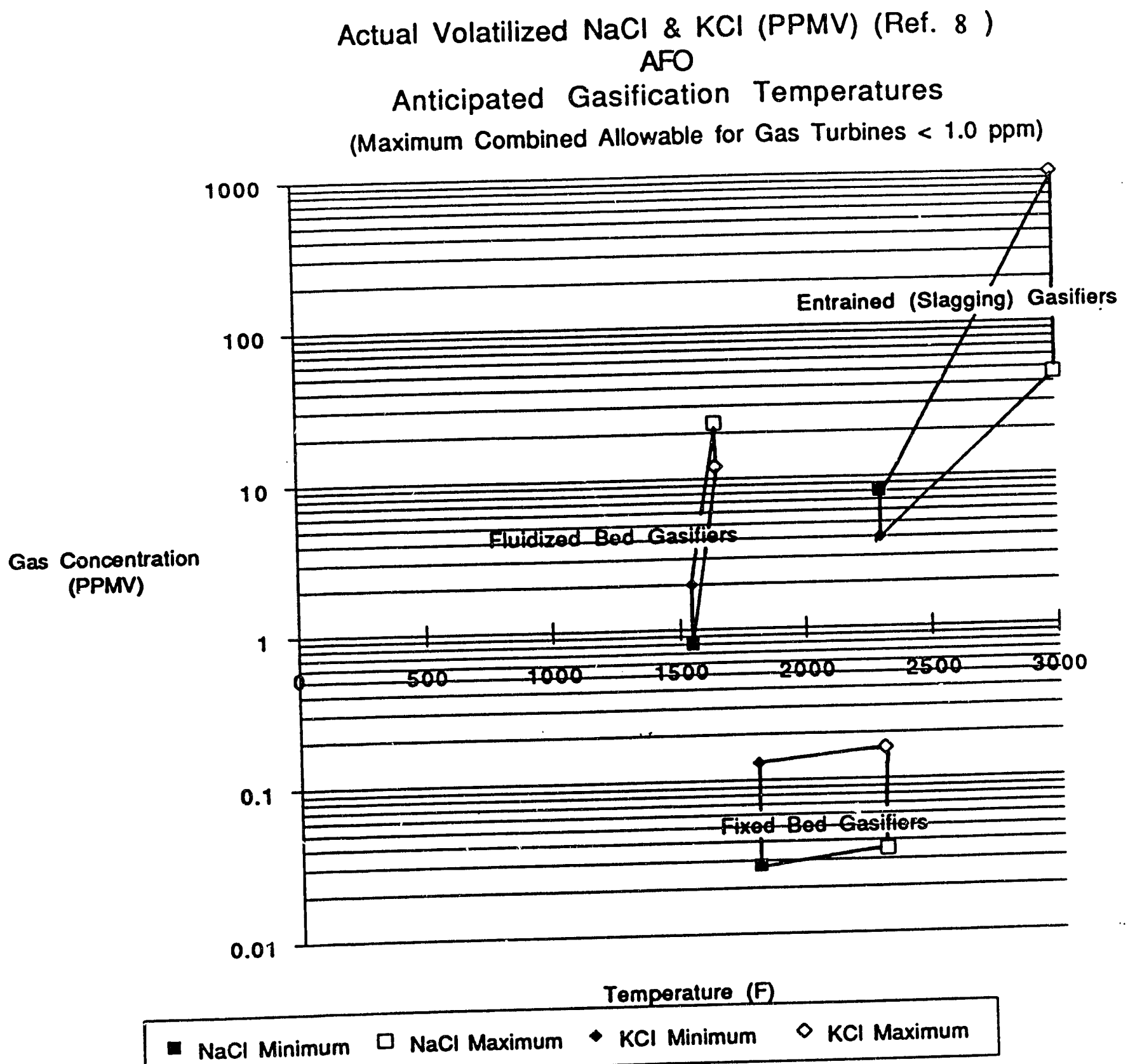

Figure 6 


\section{The PyGas Producer}

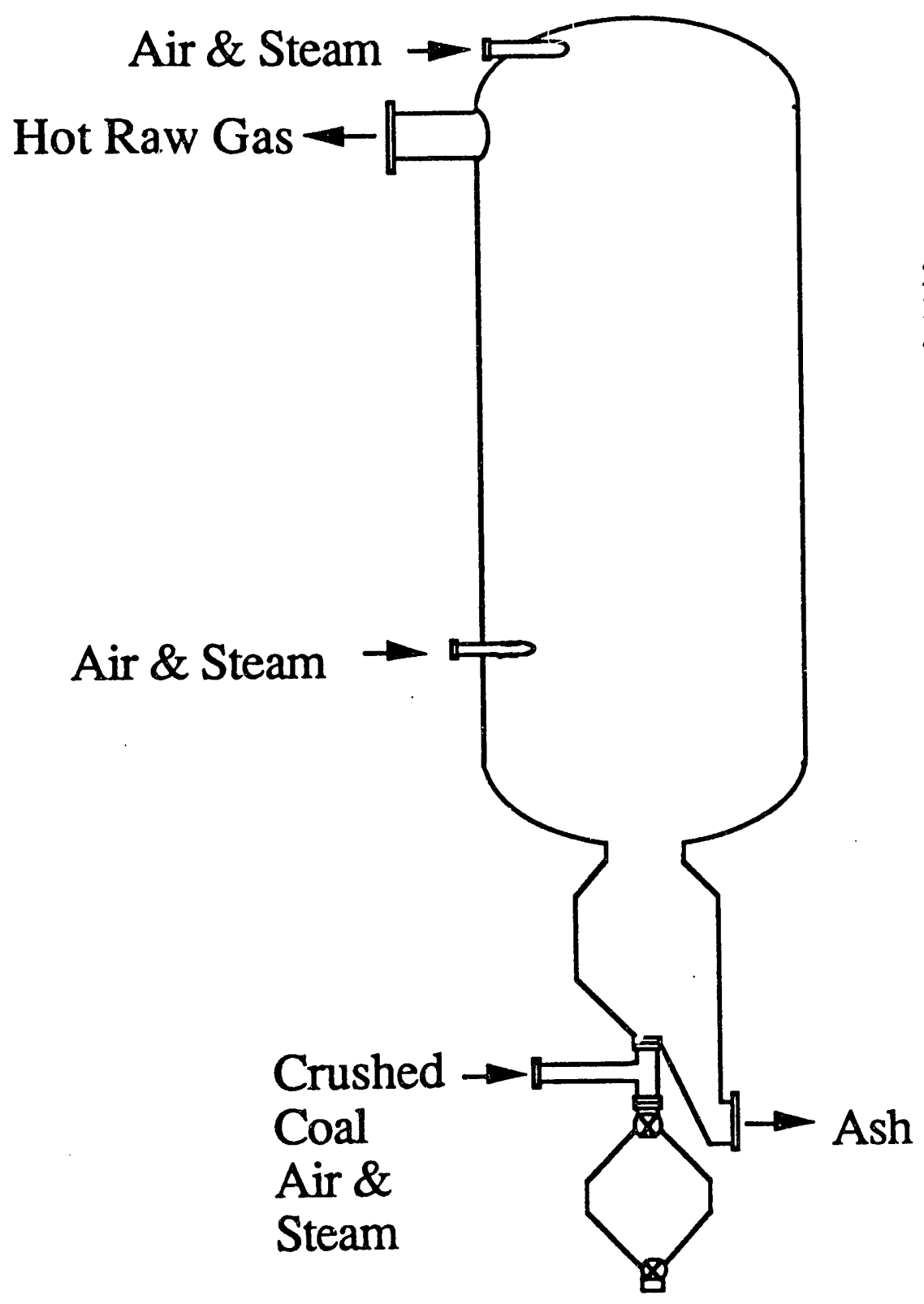

\section{Major Features}

1. Consumes Run of Mine Coal

2. Accepts Caking Coals

3. Cracks Tars

4. Consumes Fuel Moisture

5. Minimizes Volatilized Alkali Carryover

6. Continuous Coal Feed (No Lock Hopper Losses)

7. Dry Ash Removal

8. High Carbon Utilization

9. Air Blown

10. Produces Very Hot Raw Gas (Ideal for Hot Gas Cleanup)

Figure 7 


\subsubsection{Detailed Descriptions of Candidate Coal Gasifiers}

The following coal gasifiers were selected for more detailed consideration since they are all anticipated to be commercially available within the timeframe of consideration of this report (ten years). It is not the intent of this study to preclude other manufacturers from such consideration, or to imply that these represent the only such advanced coal gasifiers which may be available.

\subsubsection{Lurgi Mark IV}

The Lurgi Mark IV gasifier is approximately $41 \mathrm{ft}$ in height and $12.63 \mathrm{ft} \mathrm{ID}$ (4 meters) in diameter [1][2]. It has successfully operated at pressures in the $300 \mathrm{psi}$ to 450 psi range which is consistent with the requirements of this application. Although it has primarily operated on low free swelling coals and with oxygen, it is beiieved that it can operate successfully air-blown and (with the application of a stirrer mechanism) on higher free swelling index coals. However, experience with the operation of a full sized atmospheric air-blown coal gasifier indicates that a stirrer mechanism cannot prevent the agglomeration phenomenon from occuring, and in some cases makes channeling even worse, thereby severely curtailing gasification output. Therefore, even with a stirrer mechanism, the Lurgi Mark IV will likely be very greatly derated when operating on US coals with free swelling indexes as high as 8 . The maturity of the Lurgi Mark IV design establishes it as commercially available and financeable today. While this is a plus for this design, it also means that the normally desireable competitive market condition does not currently exist. This in turn is likely to result in higher premiums for the commencial product until such time that a more competitive environment develops.

\subsubsection{Scaled-up METC Gasifier}

One alternative gasifier candidate which could be developed, creating a more competitive environment, is the METC design [9]. This device has successful test facility sized operating experience on a wide variety of US coals. It could readily be upsized to a 13 foot ID full sized shop fabricated truck shippable vessel suitable for application to IGCC systems as defined within the scope of this project. 'It is likely to perform as well or better than the present day Lurgi Mark IV gasifier since it has a well developed stirrer and grate capable of crushing small clinkers. It is 
also likely to be limited in capacity [10] when applied to coals with free swelling indexes of 8 (FSI=8); however, if cost competitive, it could conceivably meet the economics hurdles of this study.

\subsubsection{Py-Gas Coal Gasifier}

Within the context of this study, the Py-Gas coal gasifier is a coal pyrolyzer contained within an air-blown, fixed-bed, dry bottom coal gasifier vessel. The purpose of the pyrolysis section of the device is to devolatilize the coal feed stream passing rapidly through the agglomeration zone [5][10][11] before the remaining ash/char enters ine gasification section of the vessel. In this way, the whole phenomenon of agglomeration is avoided. Since agglomeration (most pronounced with high free swelling eastern high volatile bituminous coals) is a precursor to clinkering and channeling, the device will not suffer from capacity curtailment resulting from agglomeration (Figure 8).

The use of pneumatically conveyed crushed coal (typically $1 / 4$ inch by 0 ), as the feed to the pyrolysis chamber [12][13][14][15], eliminates all concern and the costly complexity of lump coal lock hopper arrangements and their associated venting schemes.

The use of crushed coal feedstock [12][13][14][15] also enhances the use of "run of mine" coal without the added cost and complexity of a briquetting plant required by lump coal gasifier designs, further enhancing the cost competitiveness of such a coal gasifier device.

Greater gasification capacity results from the use of smaller sized coal which can react more readily than lump coal due to its greater gas-to-coal surface reaction area.

The pyrolyzer exit to gasifier entrance provides for the introduction of cocurrent air and steam flow with the char to be gasified. This, in turn, provides better temperature control of the fixed gasification bed, and results in the cracking of tars formed during the devolatization process as the cocurrent streams pass down through the hottest region of the gasifier prior to exiting the vessel. 
"We have found it useful to observe this process in a simple laboratory test. The devolatilization of a small number of particles can be studied in a simple retort under simulated gasifier exit conditions. Both the gaseous environment and temperature exiting in the upper regions in the fuel bed are recreated in the retors. The results of such a test on an eastern bituminous coal with a free swelling index of $41 / 2$ and a non-swelling northern plains lignite is illustrated in Figure 8.

In each test three pieces of sized fuel (1" X $\left.3 / 4^{\prime \prime}\right)$ were inserted into an oven preheated to a desired control temperature. The coal particles were made to touch each other and a blended producer gas mixture was fed into the oven chamber. The object of the experiment was to simulate the heating rate experienced by large coal feed particles falling onto a gasifier fuel bed. After devolatilization was complete the char particles were removed, weighed and then tested for strength in a drop shatter test.

It can be seen in Figure 8 that the swelling for each group of bituminous coal particles was not the same. Less swelling and less surface flow appears to have occurred as the temperature was increased. At high heating rates a steep temperature gradient is produced throughout the large coal particle. Under these conditions the outer layer of the particle exists in a plastic and liquid state for only a very short period. An outer semi-coke shell is formed before a deep plastic layer develops. This shell is strong enough to restrict further expansion of the particle. At lower particle heating rates temperarure gradients are much less steep. In the experiment described by Figure 8 a large agglomerated mass was formed at a temperature of $750^{\circ} \mathrm{F}$. The structure of this swollen char mass was exceptionally weak and had the fragility of a Christmas Tree ornament.

Unlike bituminous coal the lignite particles did not noticeably change in volume when heated nor did they fuse with adjacent particles. The particles appeared to ee hibit a distinct laminar structure with splintering occurring along the bedding planes.

The effect of temperature and heating rate on the strength of lignite char was found to be directly opposite to that for bituminous char. The amount of lignite char brealoge in a drop shatter test was found to increase with higher retcrt temperatures while the amount of bituminous char breakage decreased."

(INITIAL FUEL: 3 PIECES EACH 1 " $\left.\times 3 / 4^{\prime \prime}\right)$

\section{RETORT TEMPERATURE}

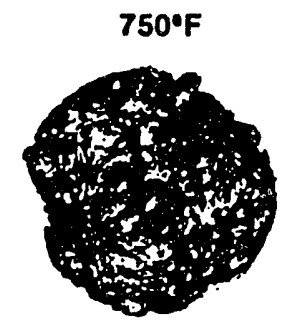

$1200^{\circ} \mathrm{F}$

$1350^{\circ} \mathrm{F}$

$1500^{\circ} \mathrm{F}$
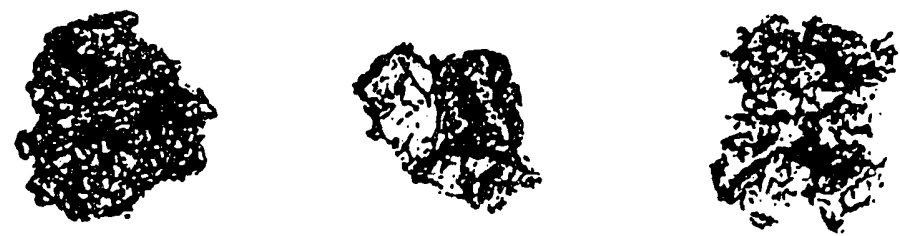

HIGH VOLATILE BITUMINOUS (FSI $=4 \mid 12)$

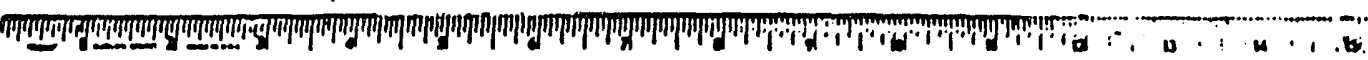
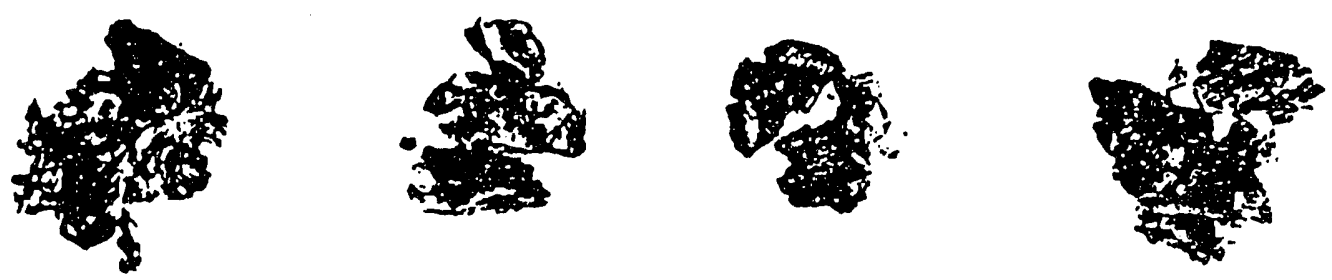

NORTHERN PLAINS LIGNITE (FSI $=0$ )

Figure 8 
Since the gas is forced to pass through the ash cooling region of the gasifier, any volatilized alkali generated in the combustion zone will be cooled and passed through the ash bed resulting in their removal prior to exiting the gasifier. This gasifier configuration also lends itself to aluminosilicate sorbent volatilized alkali removal strategies.

\subsection{Estimated System Performance}

\subsubsection{Performance Discussion}

During the compilation of capacity data, publically available empirical information was used to generate predicted system performance. Very wide ranges of gasification unit throughput appear throughout the literature [3][4][5]. The performance of an air-blown fixed bed coal gasifier is the direct result of the coal quality and characteristics utilized in a given gasifier.

\subsubsection{Performance Parameters}

In the performance of a coal gasifier, the output of the device is a function of:

3.3.2.1 The characteristics of the coal being supplied to the gasifier.

j.3.2.2 The relative quantities of air and steam fed to the coal gasifier.

\subsection{Issues Affecting System Performance}

Based upon a review of available information as presented in Sections 1 thru 3 of this report, it is anticipated that the parameters listed in the following paragraphs will affect air-blown, fixed-bed gasifier performance. At present, the exact effects of each of the parameters will require experimental determination; however, each of them has been identified as significant to IGCC coal gasifier performance.

\subsubsection{Coal Free Swelling Index (FSI)}

This index will likely have the greatest single influence on gasifier coal throughput (gas output). The literature indicates about a four to one range of output over the free swelling index (FSI) range of zero (0) to eight (8). Clearly, if a standard IGCC gasifier to be applicable to all U.S. coals up to a FSI of eight (8), this influence must be recognized, planned, and designed. 


\subsubsection{Coal Ash Fusion Temperature Characteristics}

Ash fusion temperature affects the amount of steam which must be added to the gasifier to maintain the ash below its softening temperature [2]. The lower the ash fusion temperature, the more steam that is required to prevent clinker formation.

\subsubsection{Gasifier Steam to Coal Ratio}

Steam is introduced into the coal gasifier to both cool the grate and to control the peak combustion zone temperatures below the coal's inorganic fraction melting point. The Lurgi Mark IV steam-to-coal ratio typically ranges from 0.6 to 1.7. Concern has been expressed that at high stearn flows to the gasifier, the coal derived low Btu gas mass flow to the combustion turbine can exceed turbine compressor surge margin limitations. This problem has caused CRS Sirrine Engineers, Inc. to focus attention on ways to minimize steam flow to the gasifier in an effort to avoid such turbine compressor surge margin limitations. One potential remedy under consideration is the utilization of water in lieu of steam for cooling the gasifier. Such a concept would take advantage of the evaporative process of water to provide equivalent cooling at much lower moisture flow levels. A potential secondary benefit might also be derived from the location of water injection into the gasifier air stream. If introduced between the turbine compressor and the booster compressor, the evaporative process can be utilized to reduce the temperature and volume of the air to the booster compressor saving on booster compressor power consumption. Perhaps more importantly, it averts the materials challenge and high cost attendant with high compressor inlet temperatures. In this way, the equipment, complexity, and cost of intercooling are also minimized.

\subsubsection{Coal Sizing}

Most fixed bed coal gasifiers specify very tightly controlled coal feed gradation. It is unlikely that any fixed bed coal gasifier commercially available today will guarantee acceptable performance with significant fines content in the coal feedstock, particularly for caking coals. Clearly, this shortcoming must be ' addressed either by alternative utilization of fines, or gasifier design changes 
intended to accommodate run of mine coals. The PyGas coal gasifier design addresses this inherent gasifier problem.

\subsubsection{Tar Production}

Tar production can be minimized by various operational techniques, however some tar should always be expected from a fixed-bed gasifier. Several gasifier suppliers have reduced tar production by readmitting volatiles produced gas back through the char bed region. The PyGas coal gasifier design addresses this inherent gasifier problem by forcing the tars produced in the volatilization process to pass through the peak gasifier temperature zone where they are cracked.

\subsubsection{Volatilized Alkali Production}

From available data (Figure 0), it appears that the hotter the gasification process, the greater the volatilized alkali production. Slagging entrained bed gasifiers produce about three orders of magnitude more sodium and potassium than gas turbine manufacturers consider acceptable. Fluid bed gasifiers produce about two orders of magnitude more than is acceptable. Only fixed-bed, nonslagging gasifiers appear capable of maintaining sufficiently low volatilized alkali levels for direct hot gas utilization gas turbines without post gasifier treatment of the alkali vapors.

\subsubsection{Thermal-phoresis}

It is known that when gasifier exit temperatures are maintained well above the tar condensation range, the tars and heavy oils tend to crack. The resulting coke has an affinity for accumulating on any and all duct surfaces irrespective of duct refractory temperatures. The term "thermal-phoresis" has been used to describe this phenomenon. Historically, the best way to deal with it is to minimize the extent of any ductwork between the gasifier outlet and the hot gas cleanup unit (HGCU). Other obvious treatments such as soot blowers may have deleterious affects on the HGCU process. 
Typically, pressurized lock hopper arrangements which are located near the gasifier have an associated thermal loss from gasifier hot gas product venting. Sucii venting is necessitated by the admittance of hot raw gas product during the coal feed sequence. This hot raw gas is at operating pressure and hence must be vented before the coal bunker side valve is opened to atmosphere. Depending upon where and how the gas is vented, it can be a significant loss from the process.

The use of pneumatically conveyed crushed coal (typically $1 / 4$ inch ty 0 ) as the feed to the pyrolysis chamber of the PyGas gasifier, eliminates all concern and the costly complexity of lump coal lock hopper arrangements and their associated venting schemes.

\subsubsection{Gasifier Air-to-Coal Ratio}

The air-to-coal ratio to the gasifier is set by the gasification reaction requirements to consume the coal and produce low Btu gas therefrom. Typically for the Lurgi Mark IV gasifier, this ratio ranges from 1.3 to 1.9. For coals requiring air flows on the higher end of the range, care must be exercised in the admission of steam (again perhaps via the use of water) to the gasifier so as not to exceed combustion turbine surge ratio limitations.

\subsubsection{Ammonia \& Cyanide Production}

All fixed bed gasifiers are likely to produce some ammonia and cyanide. A relatively large fraction of this "fuel bound nitrogen" is likely to become NOx when the gas is combusted in the gas turbine. There appears to be little that can be done in the gasifier to mitigate fuel bound nitrogen production. Therefore, to achieve NOx emission levels of $0.1 \mathrm{lb} / \mathrm{MBtu}$, down stream NOx reduction and removal strategies (e.g. staged combustion, NOx reburning, ammonia injection, and SCR) are expected to be necessary and employed. 


\subsubsection{Ash Carbon Content}

Ideally, gasification should proceed with near complete utilization of the carbonaceous fraction of the coal. Durirg upset conditions such as gas channeling due to clinkering caused typically by high free swelling coal properties, significant quantities of unburned carbon may occur. This negatively affects both process efficiency and ash disposal since ash disposal cost is affected by its carbon content. Since coal ash which contains less than $5 \%$ unburned carbon can be stabilized, a reasonable goal for the standard IGCC gasifier is to maintain less than 5\% carbon in the bottom ash.

\subsubsection{Pressure Containment}

It is anticipated that the standard IGCC gasifier will be operated at various pressures depending primarily on output required and coal characteristics. Pressure drop across the gasifier in addition to the attendant pressure losses of the systems downstream of the gasifier (tar and particulate removal, desulfurization/ regeneration, etc.) will culminate in the need for a booster compressor (or similar device) which allows the gasifier to operate at significantly greater pressures that the gas turbine. This presents a formidable need to adequately seal all gasifier penetrations against a hot, high pressure environment. Several gasifier suppliers have met this challenge to pressures in the $350-450 \mathrm{psig}$ range. The remaining question is one of maintainability of the hardware involved.

\section{REFERENCES}

1. "Coal Gasification Processes", Nowacki, Perry ed, Noyes Data Corp., Park Ridge, New Jersey, 1981

2. "Coal Gasification", VonFredersdorf and Ellioth, in "Chemistry of Coal Utilization", Supplementary Volume, Ed. H.H. Lowry, John Wiley \& Sons, Ner York, 1973

3. "Environmental Assessment Data Base for Low/Medium-Btu Gasification Technology, Vol II.", Cavanaugh, E.C., et al. Radian Corp., Austin, TX, Nov. 1077, (ERA/600/777/125B) 
4. "Strongly Caking Coal Gasified in a Stirred-Bed Producer", U.S. Bureau of Mines RI 7644,1972

5. "Practical Operating Experience on a Riley Gasifier", Early, W.P., et al., 88th National Mtg. AIChE, June, 1980

6. "Chemistry of Coal Utilization", Supplementary Volume, H.H.Lowry Editor, John Wiley \& Sons, N.Y., 1963, 1142 p

7. "External Corrosion \& Deposits in Boilers and Gas Turbines", W.T. Reid, American Elsevier, N.Y., 1971, 199p

8. "Ranges of Contaminant Concentrations from Illinois No. 6 Coal Oxygen Blown Gasifiers and Combustors", DOE/MC/23088.2532

9. "Coal Combustion and Gasification", Smoot, L. Douglas, and Philip J. Smith, P!caum Press, New York, 1985

10. "Operation of a Commercial Size Riley-Morgan Coal Gasifier", Rawdon, A.H., et al., American Power Conference, April, 1976

11. "Source Test and Evaluation of a Riley Gas Producer Firing North Dakota Lignite", Jones, Fred, et al., Symposium on Environmental Aspects of Fuel Conversion Technology, October, 1981

12. "Production of Low BTU Gas Involving Coal Pyrolysis and Gasification", Wen, C.Y., et al., Coal Gasification, L.G. Masey, Advances in Chemistry, No. 131, pp9-28, American Chemical Society

13. "Entrained-Bed Carbonization of Bituminous Coals", Gomez, M., et al., U.S. Bureau of Mines, RI 7141, 1968

14. "Partial Devolatization of Coal in Two Entrained-Bed Carbonizers", Boetler, D.C., C.C. Boley, U.S. Bureau of Mines RI 7843, 1973 
15. "Multi-Stage Desulfurizing Fluid-Bed Combuster for Coal-Fired Hot Gas Generator Systems, Topical Report 2, Burner-Pyrolyzer Interactions", Dawson, W.F., ET-78-C01-2859, 1980 


\section{Design \& Performance of Standardized Fixed Bed Air Blown Gasifier IGCC Systems}

Section 4

January 1991

Work Performed Under Contract No. DE-AC21-89MC26291

For

U.S. Department of Energy

Office of Fossil Energy

Morgantown Energy Technology Center

P.O. Box 880

Morgantown, West Virginia 26507-0880

B y

CRS SIRRINE, INC.

Power Division

P.O. Box 5456

1041 East Butler Road

Greenville, South Carolina 29606-5456 


\subsection{Summary}

This specific section is intended to evaluate advantages/disadvantages of candidate coal gasifiers matched with combustion turbine/HGCU modules. It also provides for the development and expected performance characteristics of selected advanced coal gasification machines as required to accommodate program objectives. Included is the assimilation of empirical data and industry experience describing optimized combinations of air-blown Fixed Bed Gasifier/HGCU/Combustion Turbine combinations.

Information developed by the Department of Energy's Morgantown Energy Technology Center (METC), CRS Sirrine Engineers, Inc., and that of a number of cogeneration and independent power production developers have been objectively and subjectively evaluated in the development of this study.

The results indicate that although the anticipated first system costs will be relatively high, the assumption of pre-engineered standardized and modularized systems for Commercial Gasification IGCC Application (CGLA) systems results in an "Nth unit" total facility cost of under $\$ 1,000 / \mathrm{kwn}$ in sizes larger than $200 \mathrm{MWe}$. The resultant ten year levellized cost of electricity (COE) reflected the low CGIA standardized plant cost advantage.

Several issues relating to cost barriers to achieving the economic goals set for the study were broached. The first was to avert combustion turbine output limitations caused by encroachment on compressor surge margin limitations due to high low Btu coal gas mass flows to the turbine combustor. It was noted that the steam flow to the gasifier for grate cooling and gasifier peak combustion temperature limit control was the basic cause of excessive fuel related mass flow to the combustion turbine. The approach of replacement of gasifier steam flow with spray water flow upstream of the booster compressor was found to serve two worthwhile purposes. It allowed the combustion turbine to operate at full output by reducing the net fuel mass flow to within turbine manufacturer surge margin limits. It also reduced the turbine compressor outlet temperatures to tolerable limits to the booster compressor without the need for intercooling, thereby saving on both intercooling and booster compressor costs. 
Anower issue dealt with by this study was the cost/benefit of several basic sulfur recovery strategies downstream of the hot gas cleanup unit (HGCU). It was determined that the most costly strategy would be elemental sulfur recovery, followed by sulfuric acid production, and finally direct sulfur dioxide recovery. The one potential exception to this order might be elemental sulfur recovery via the ReSox process. The potential advantage of this method of elemental sulfur recovery may be the utilization of the (otherwise lost) carbon from the gasifier ash to reduce the SO2 stream to elemental sulfur in the reductor vessel. There appears to be sufficient carbon loss in the gasifier ash to meet the carbon combustion requirement for the burning of free $\mathrm{O} 2$ and reduction of $\mathrm{SO} 2$ in the HGCU SO 2 bleed stream. The strategy of $\mathrm{SO} 2$ recovery by condensation and pumping to liquid SO2 tanks appears to he both lowest in capital cost, and highest in byproduct sales value. This is apparently due to the broader market spectrum for SO2 than either of the other two forms of sulfur recovery.

The study also identified rich/lean 50\% NO reduction during combustion at the turbine in addition to ammonia injection with SCR reduction of $80 \%$ in the HRSG as a required combined NOx control strategy for achieving the study goal of 0.1 lb/MBtu emission limitations. This method of NOx control was the result of the consideration of $40 \%$ of the coal gasification generated ammonia to NO conversion at the combustor. The notion that coal gasification with water injection at the booster compressor as noted above will result in less ammonia generation was not considered since such low moisture gasification levels have not yet been widely demonstrated. Some testing has been dơne at low steam injection flows. Based upon the apparent relationship of ammonia generation with increased steam injection to the gasifier suggests significant ammonia generation control may be possible with reduced gasifier moisture levels. The extent to which lowered ammonia levels may alter the ammonia to NO percent conversion has not been addressed herein.

The consideration of a supplemental low Btu coal gas fired HRSG as an alternative NOx control strategy to ammonia injection and SCR by NO reburning was reviewed. The consideration was the tradeoff between the additional first cost of the supplementally fired HRSG vs. the considerably higher continuing operating cost associated with ammonia and potential catalyst contamination and required 
replacement intervals. No clear direction evolved from the level of depth of this study's effort in this area, and it remains an issue for future consideration.

This study also identified existing coal fired utility power plants as near term candidates for standardized CGIA application. While many $\mathrm{co}^{\prime}$, ider conventional flue gas scrubbers as the economical solution to the emissions concerns of large coal fired utilities, such systems are expensive and adversely affect power plant efficiency by consuming significant quantities of power which would have otherwise been available to the grid. In effect, while reducing stack emissions, scrubbers return reduced plant electricity output for their significant expense. Retrofitting and repowering existing coal fired power plants with CGIA results in much lower emissions than currently available commercial scrubber systems plus very substantial increased power output for the same coal input for which the facility has already been designed.

There is solid justification for the consideration of the addition of CGIA systems to existing coal fired utility plants. The majority of the most costly of the capital cost items of the power plant already exist. These include coal receiving/handling/ storage/reclaim, water sourcing/purification/treatment/disposal, electricity generation/conditioning/distribution, and the most costly of all, the boiler island itself. Unlike other repowering strategies which require replacement of the boiler island, this study presents a way to simply add on the IGCC system to the existing coal plant with minimum modification to the existing infrastructure. The result is an approximate $20 \%$ increase in power output while reducing the plant's stack gas emissions by well in excess of $90 \%$ for $\mathrm{SO} 2, \mathrm{NOx}$, and particulates.

\subsection{Integration \& Matching of Commercial Gasification IGCC Applications}

The initial efforts of combining the various systems which comprise the Commercial Gasification IGCC Applications (CGIA) (Figure 1) revolved around establishing an engineering level mass and energy balance [1][2][3] sufficient to identify the processes involved (Table $1 \mathrm{a}-\mathrm{d}$ ). Appendix $\mathrm{C}$ includes reasonably complete mass and energy balances for the nominal $50 \mathrm{MWe}, 100 \mathrm{MWe}, 200 \mathrm{MWe}$, and utility retrofit/repower cases. Several combinations of inputted coal analyses with actual 


\section{Combined Gasifier IGCC Application (CGIA)}

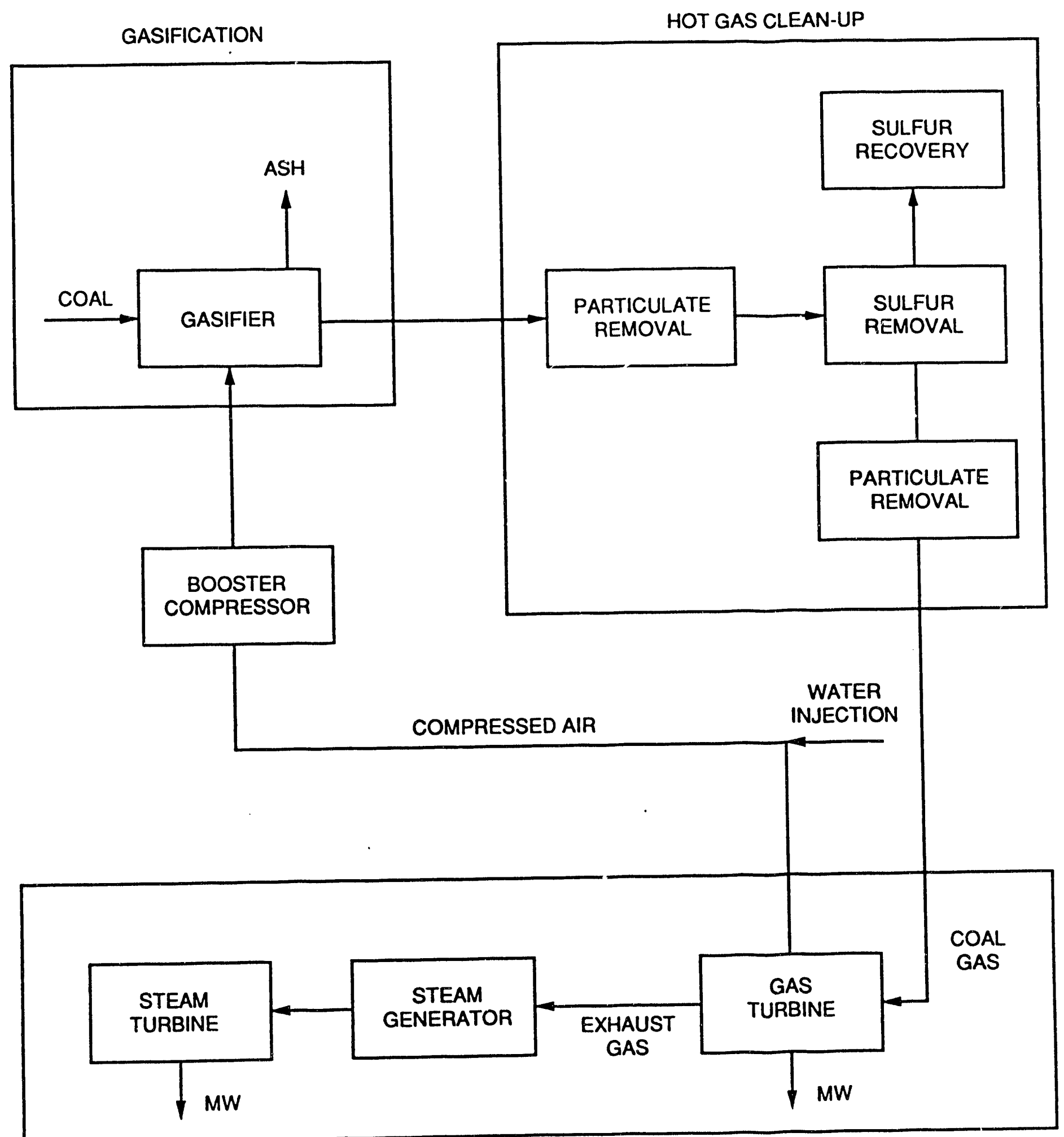

POWER GENERATION

Figure 1 


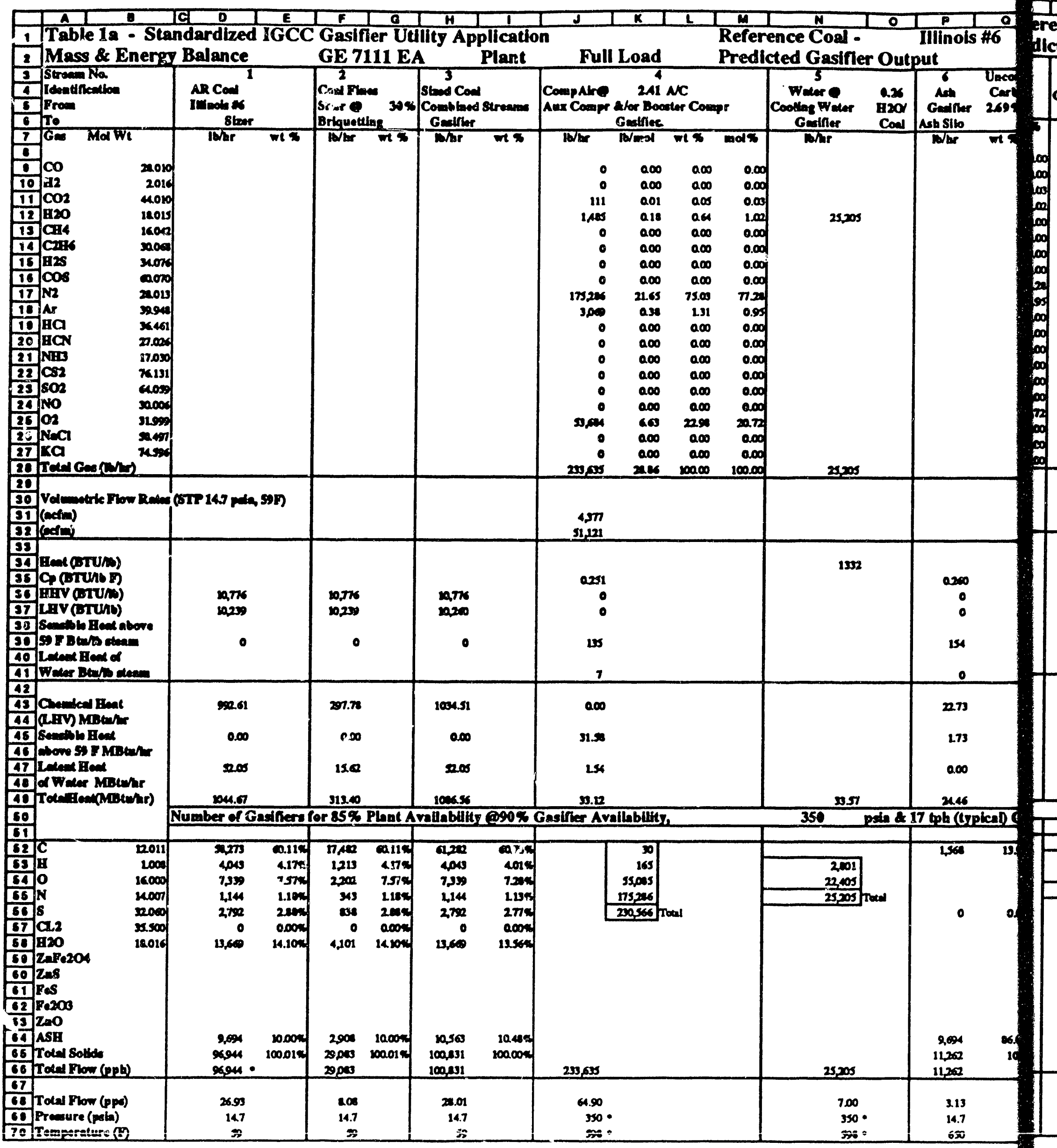




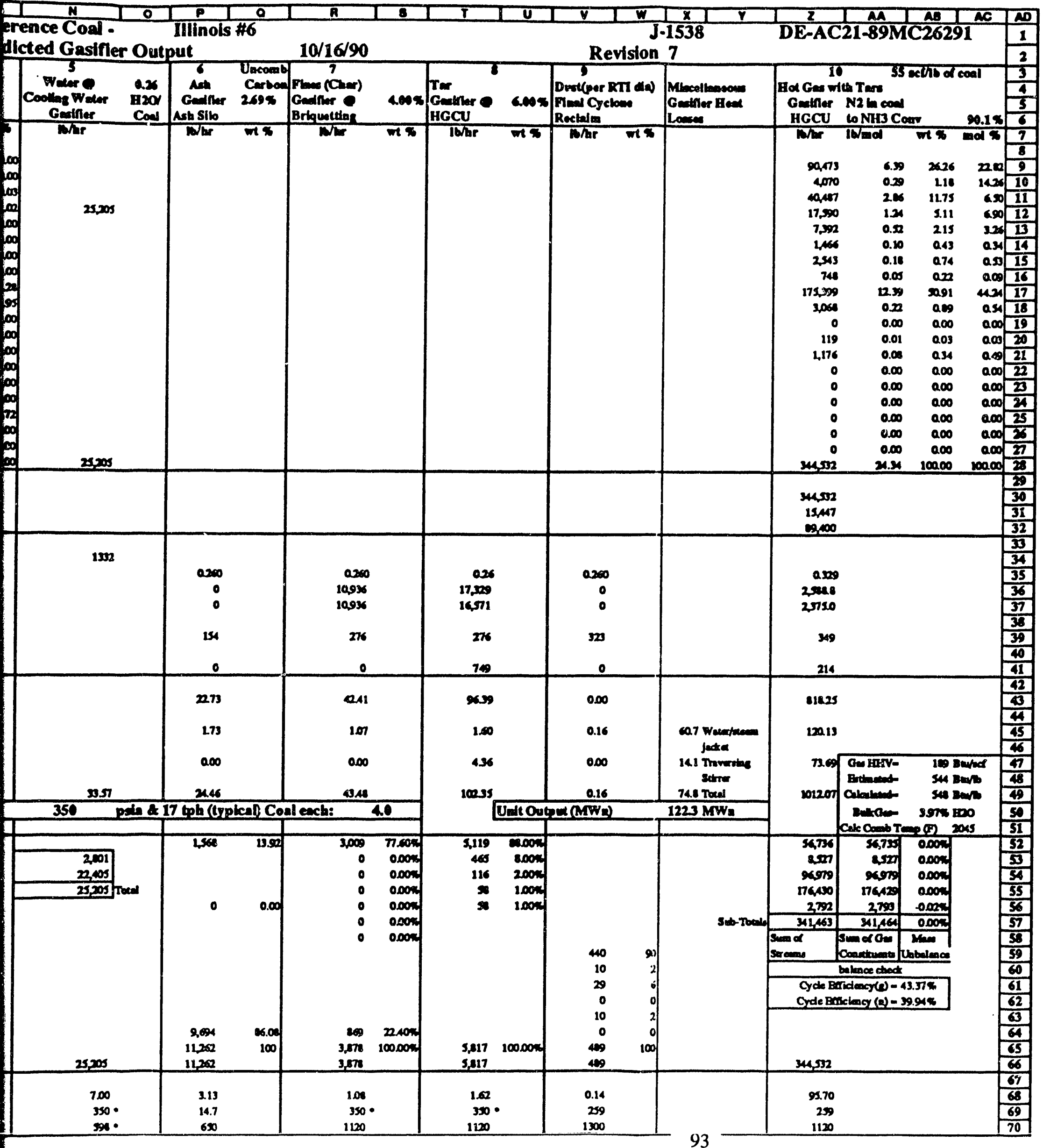




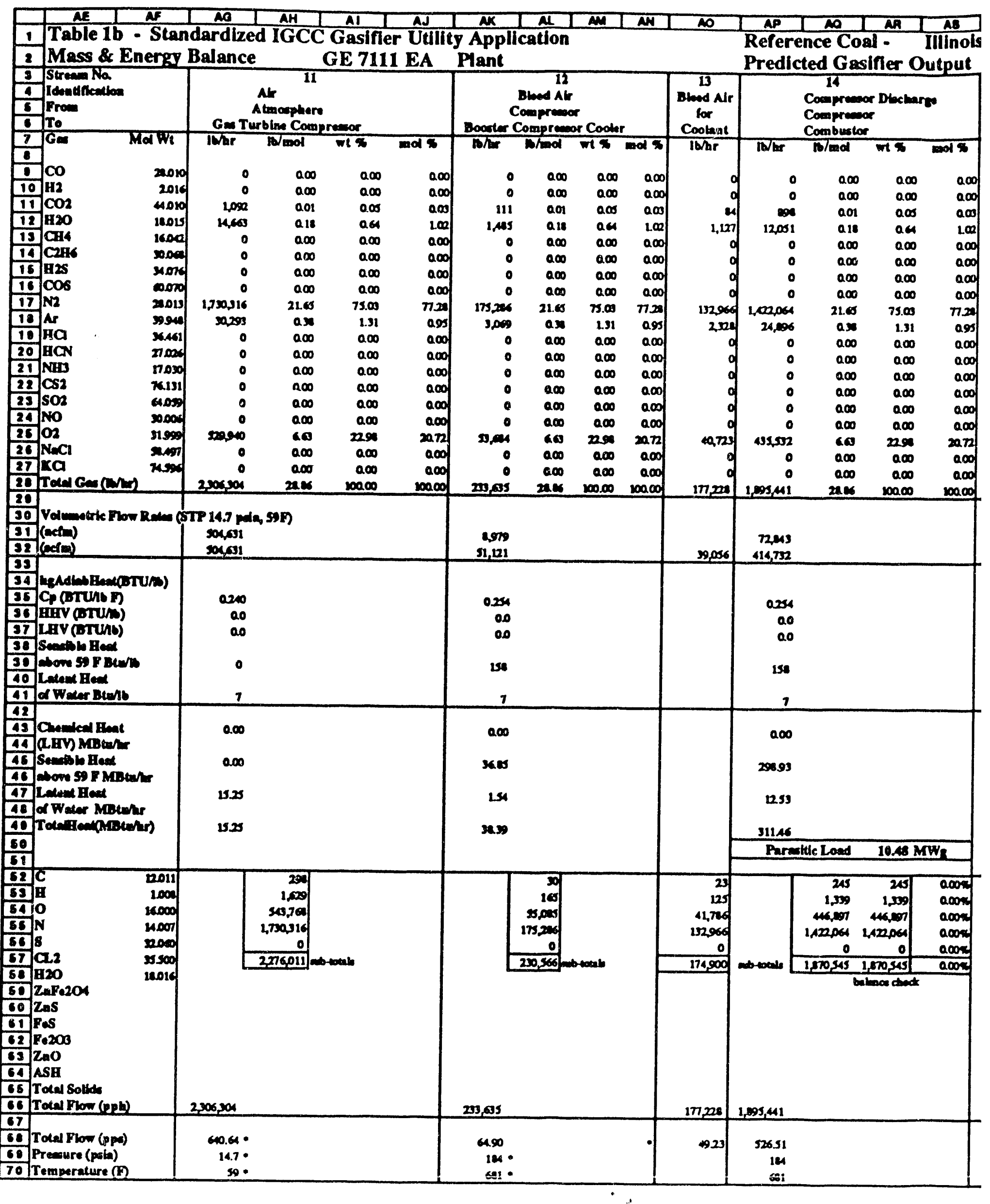




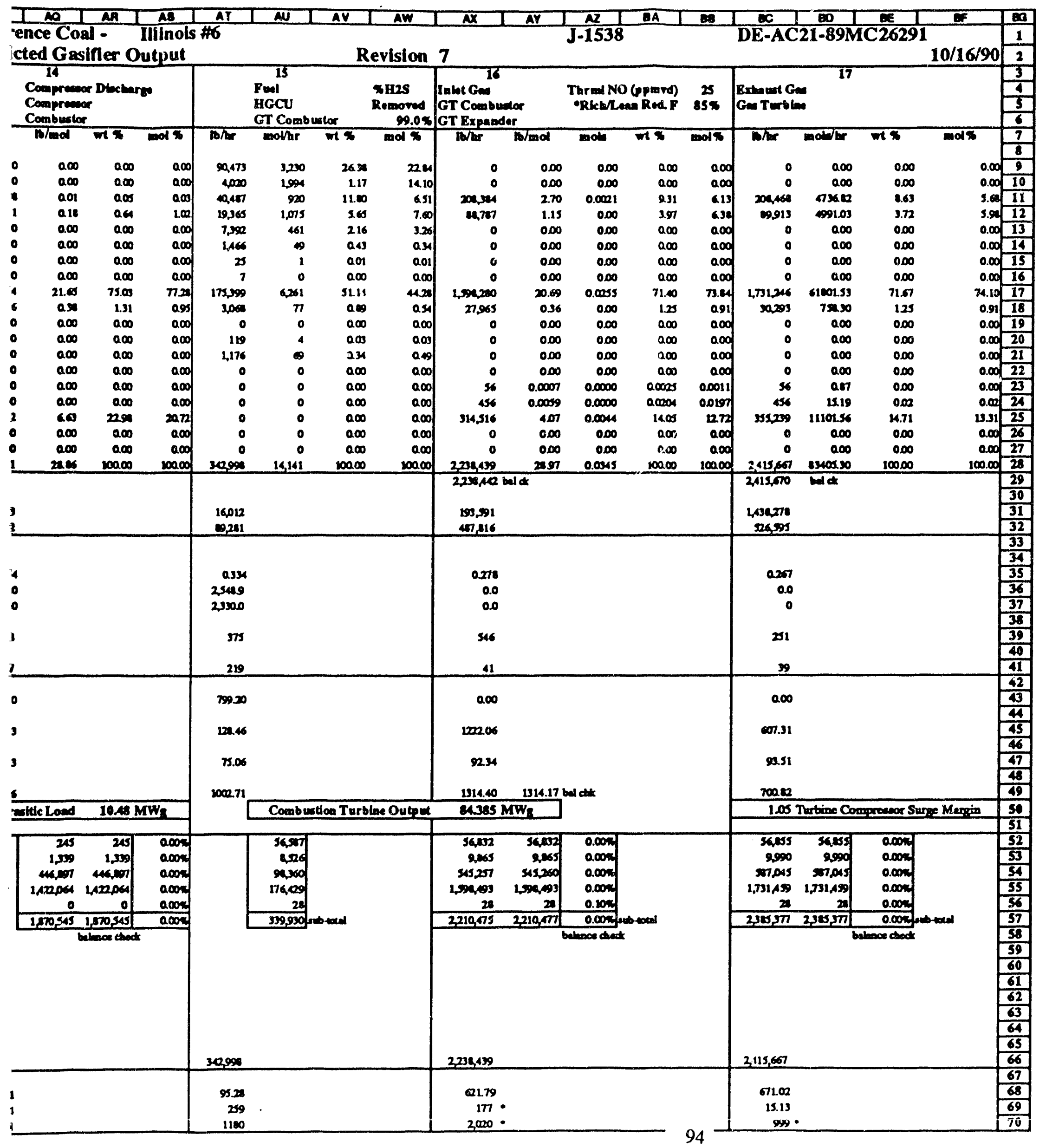




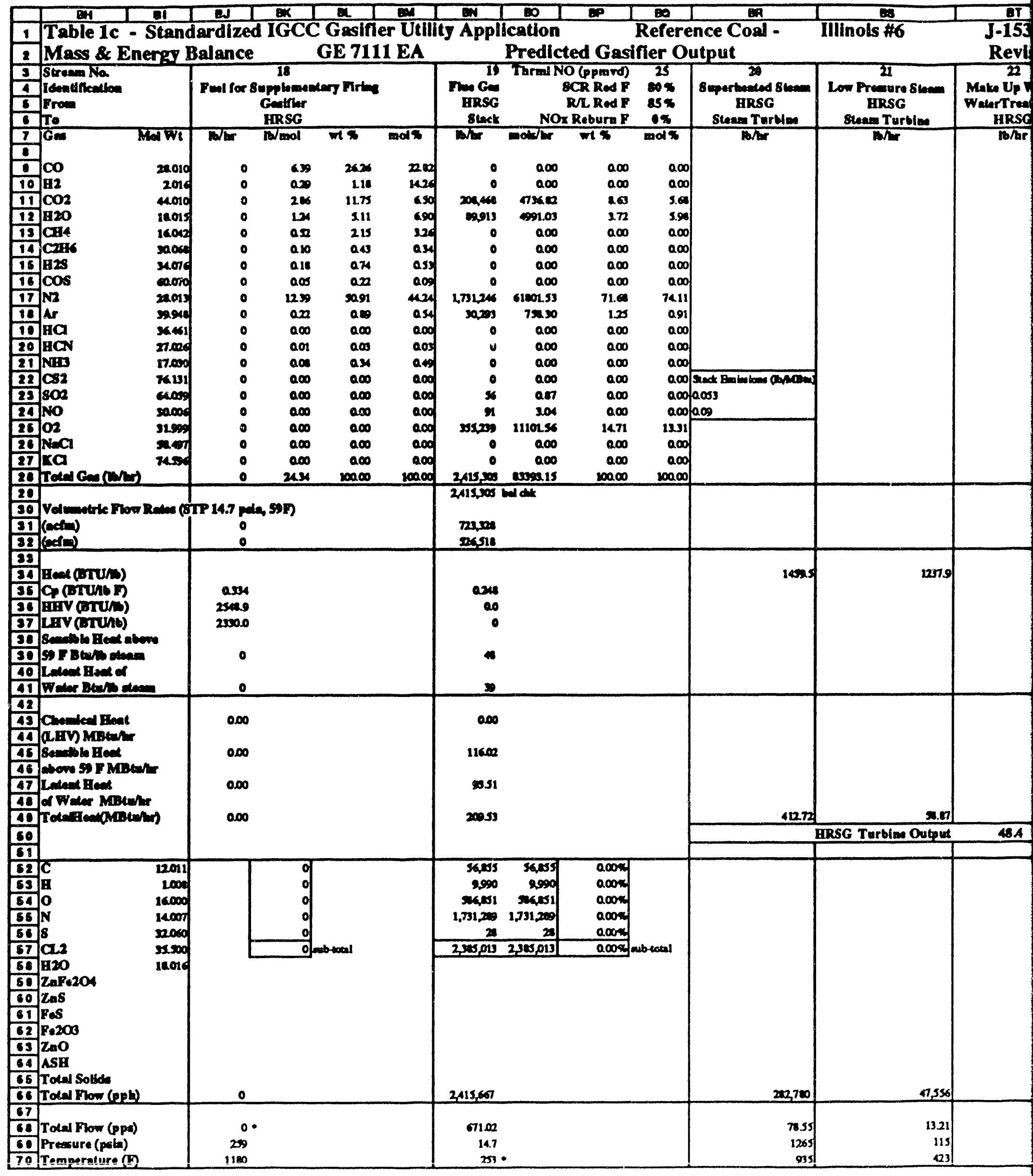




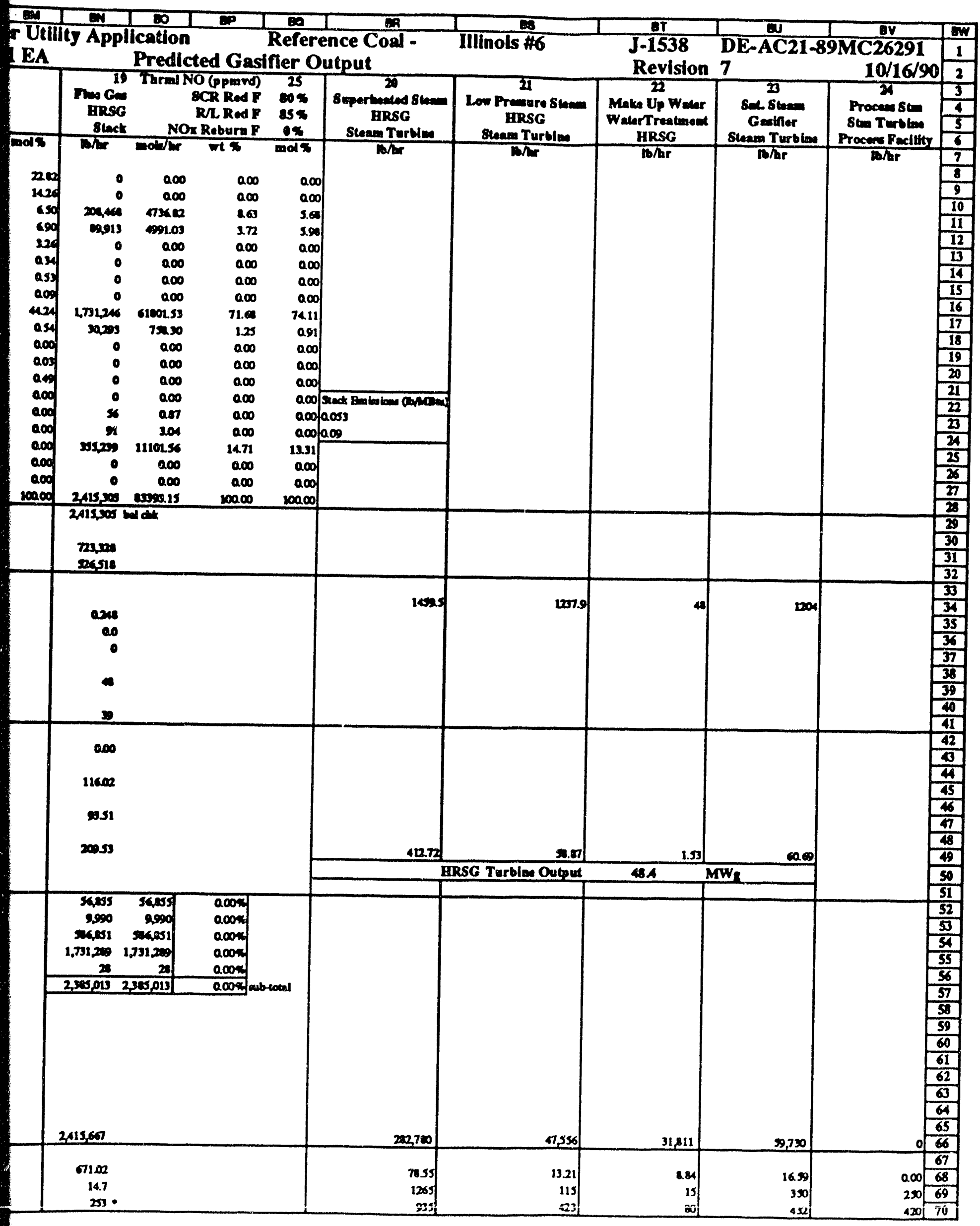




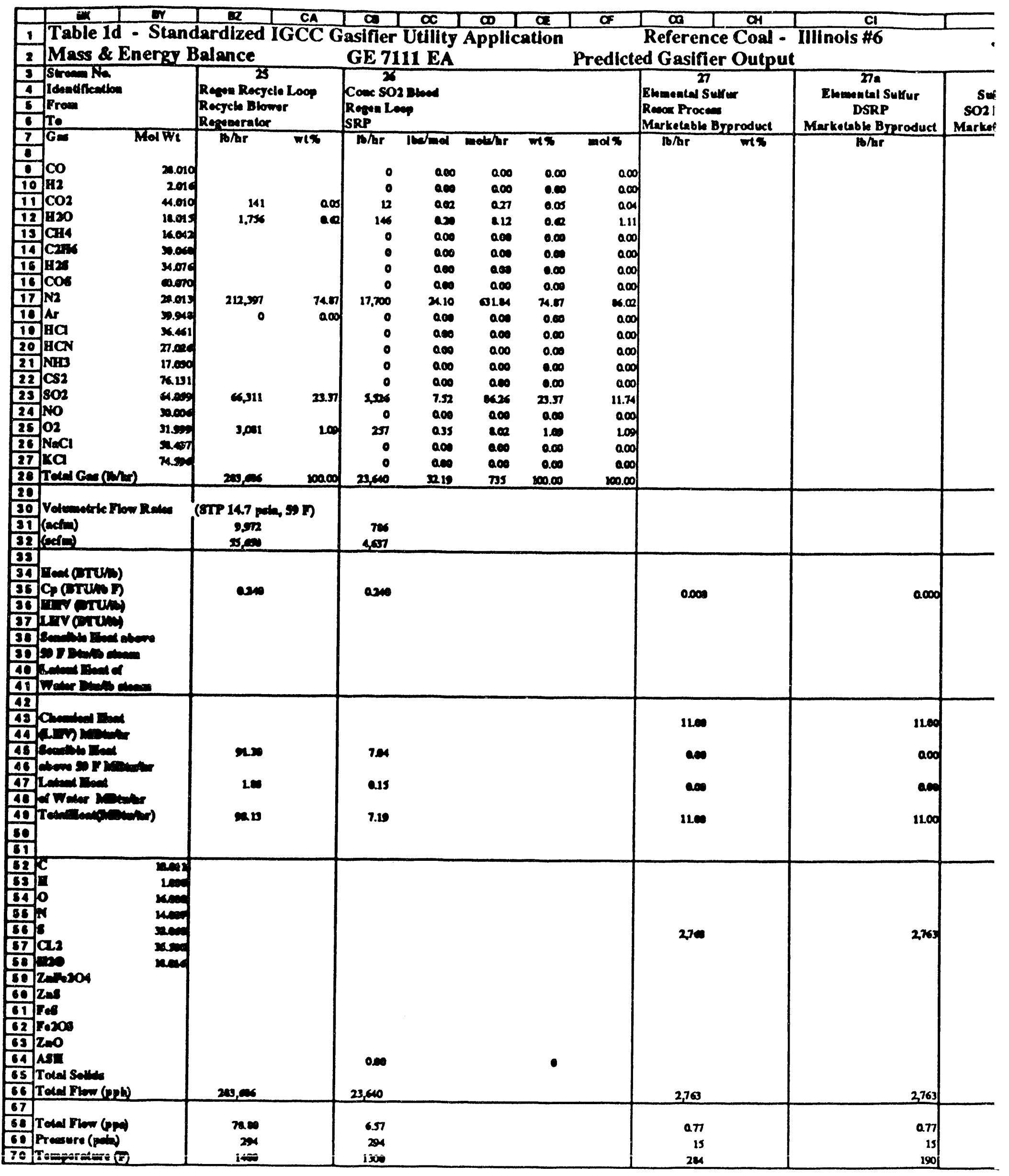




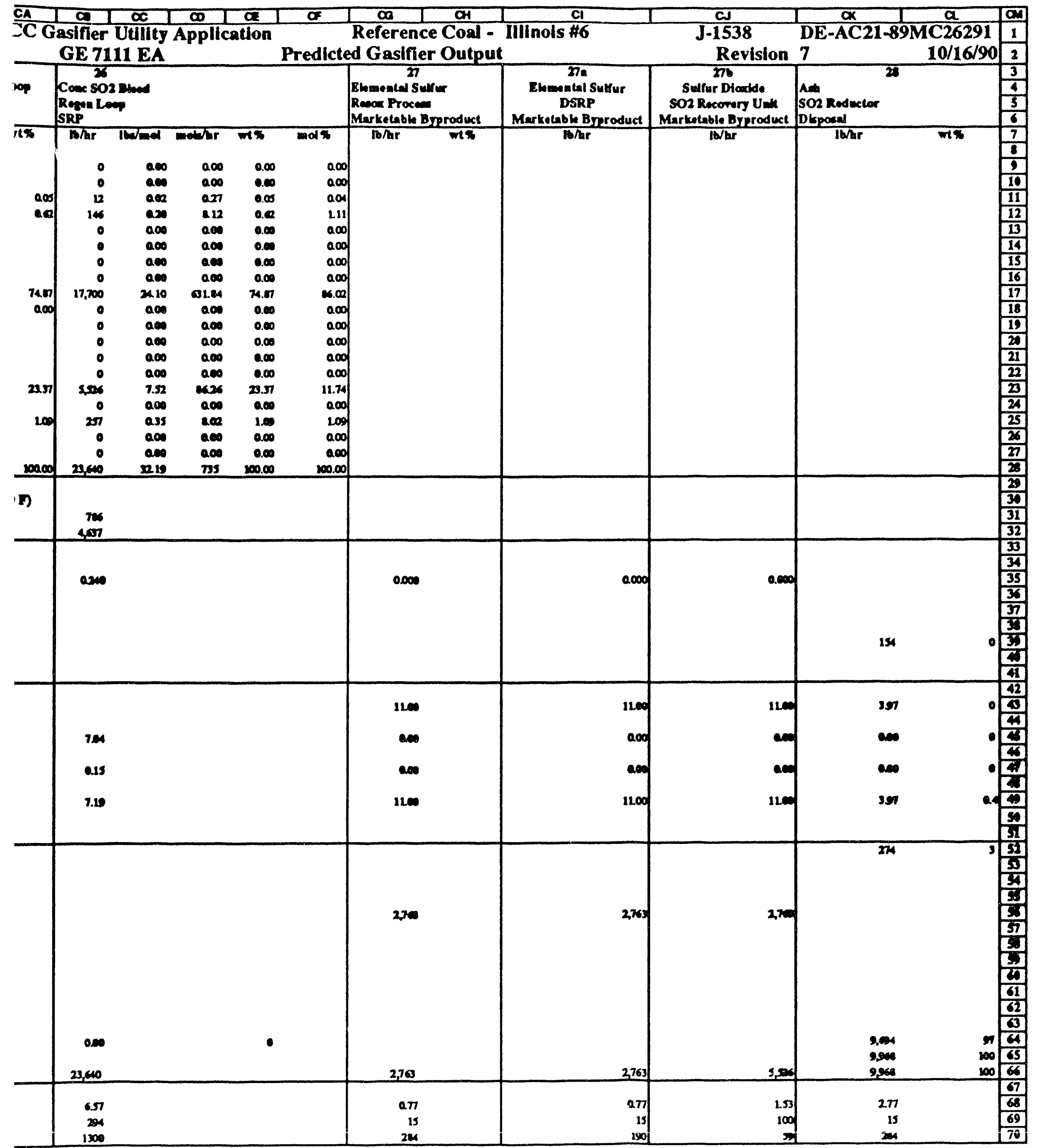


and predicted coal gasifier outputs were studied to get an idea of ranges and constraints to be expected when changing coals.

Once satisfied that the mass and energy balances were reasonably accurate, the empirical relationships developed by others (Figure 2) with actual coal gasifier operating experience [4] of the type of gasifier selected were superimposed into the balances (both Microsoft Excel \& Lotus were used to build the spreadsheets) which appear in Appendix C.

\section{Low BTU Gas Analysis vs. Water (GE Data) Points@4.43\% \& 6.26\% H2O are Projected}

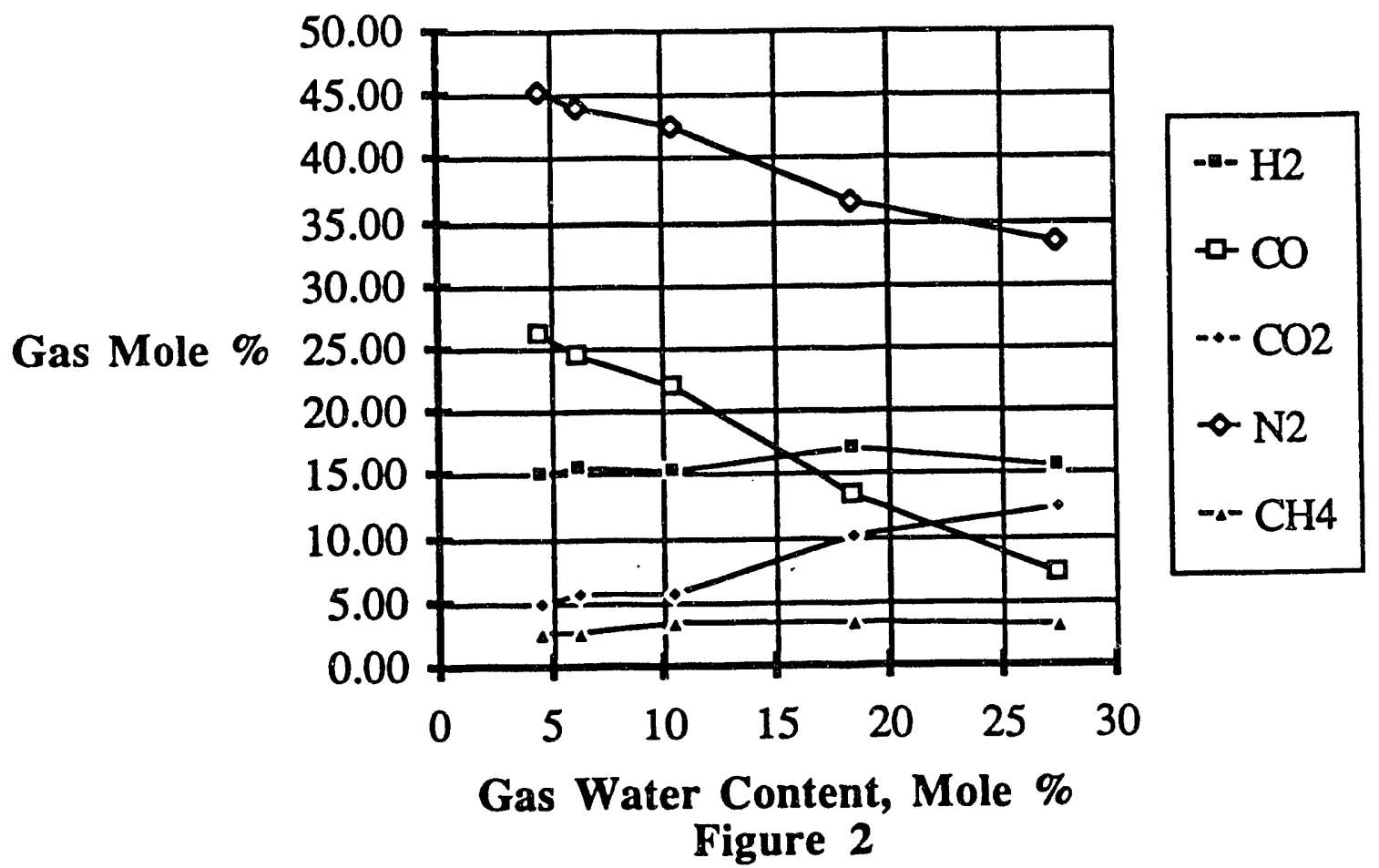

Gasifier sizing consistent with an expected 85\% plant availability

(Table 2) criterion was utilized. Assuming no alternate fuel backup (such as natural gas to fire the combustion turbines when necessary), and an individual gasification/HGCU modular island availability of $90 \%$, each unit must be sized for $150 \%$ design capacity to achieve a total plant availability of $85 \%$. Table 3 serves to identify the loss of overall plant availability when the number of gasification/HGCU modules is reduced to two. For the larger plants which require eight truck shippable gasification modules, the 
same statistical probability analysis (Table 4) shows the individual module design overcapacity can be reduced to $15 \%$ to $20 \%$ while the total plant availability increases to $88 \%$. The effect of capacity factor (or availability) on cost of electricity (COE) is as shown on Figure 3. It should be noted that while the actual anticipated module availability is arguable since none have yet been built, this availability analysis serves to show the added value which multiple modular parallel path systems brings to any total facility. This very same logic has been utilized by the utility industry for many years with respect to the numbers of identical modularized coal pulverization

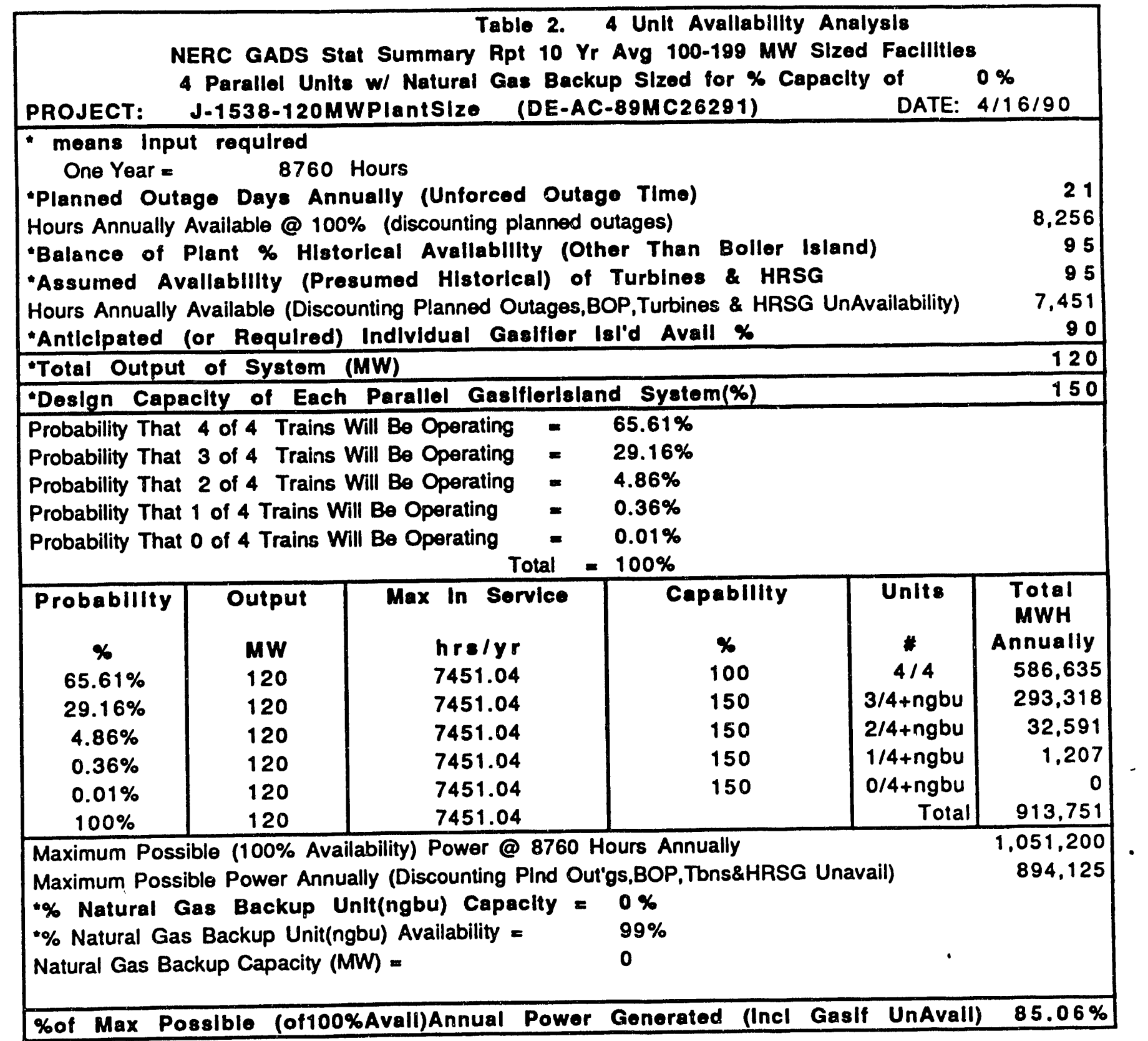




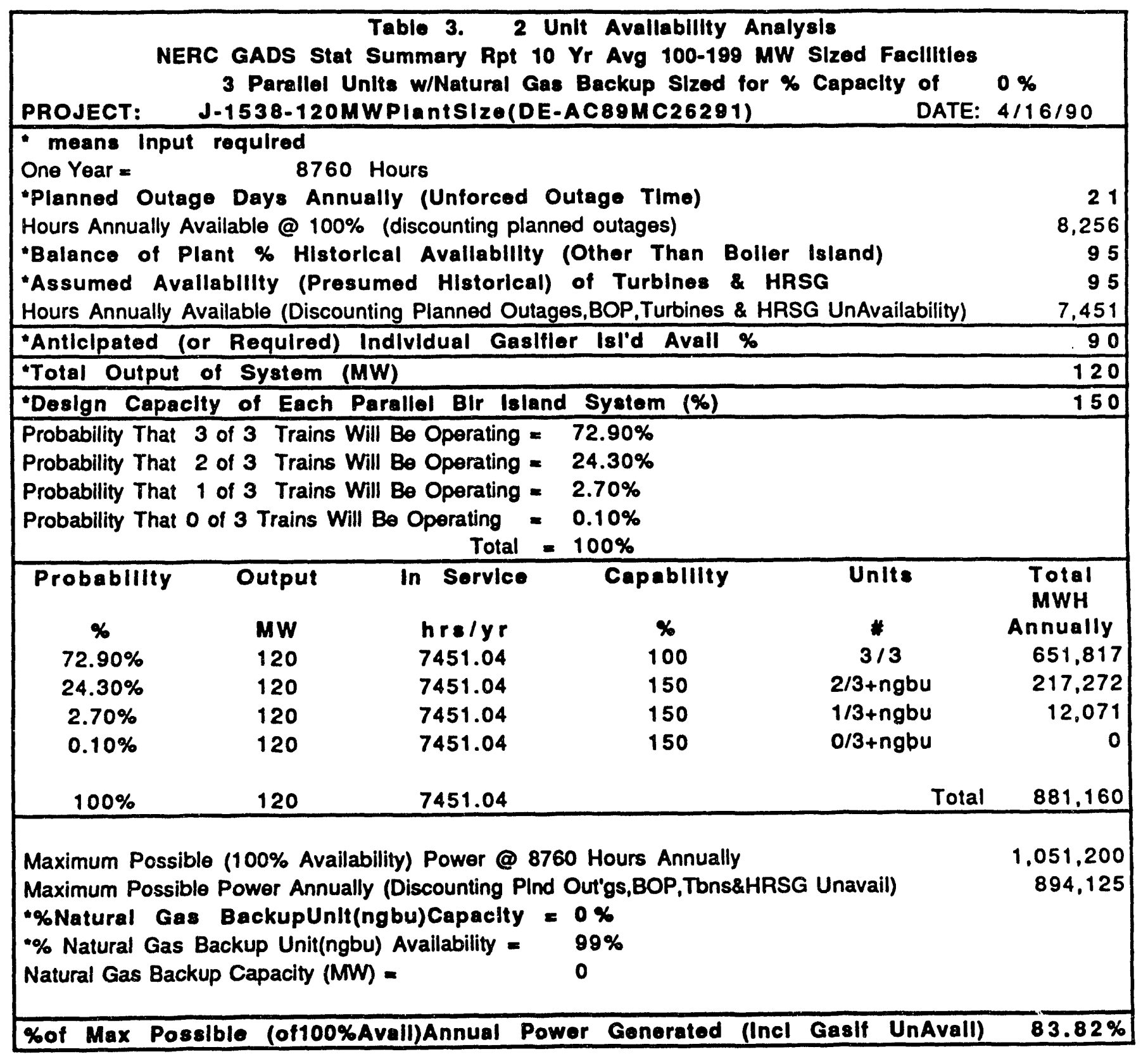




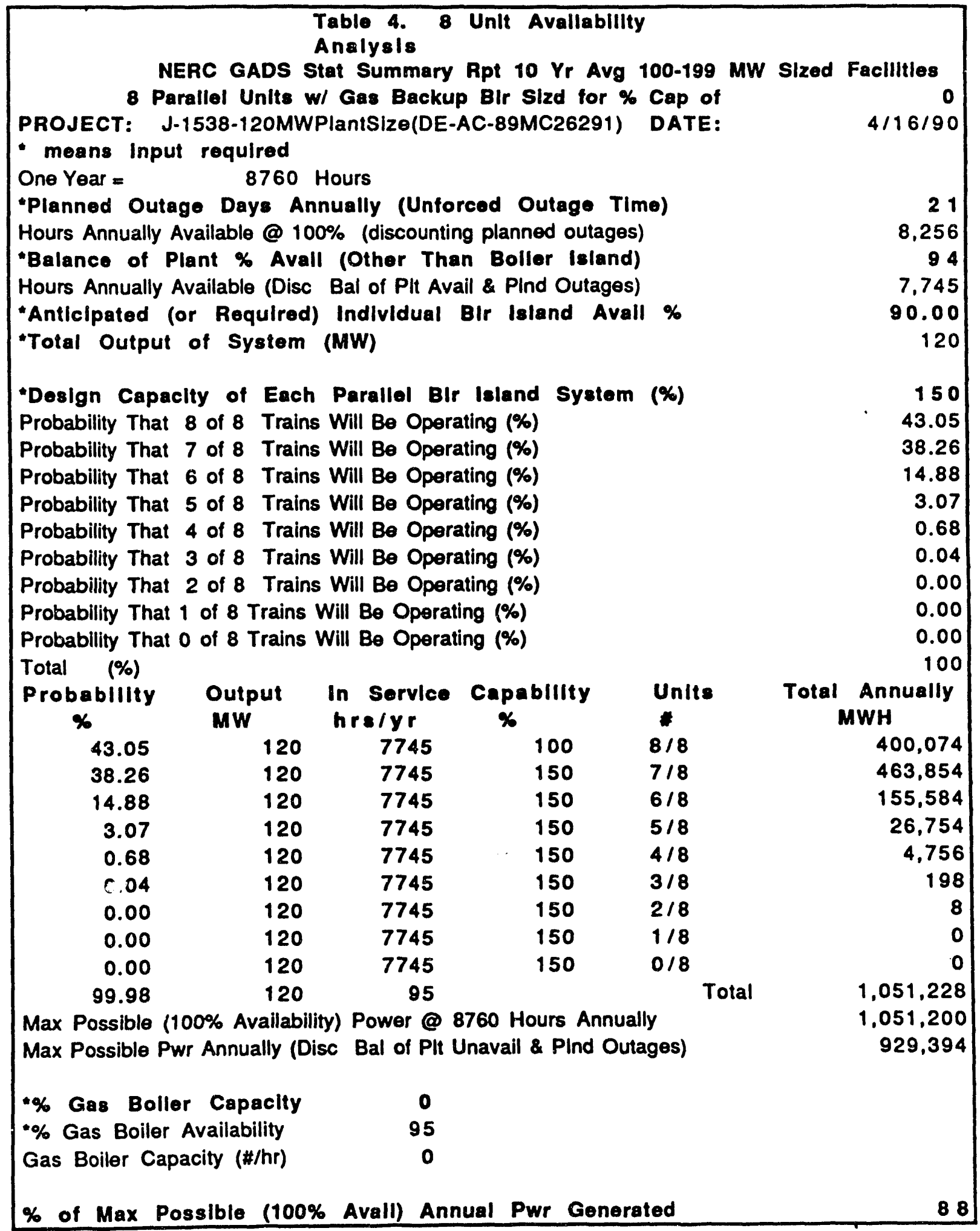




\section{Cost of Electricity vs. Capacity Factor}

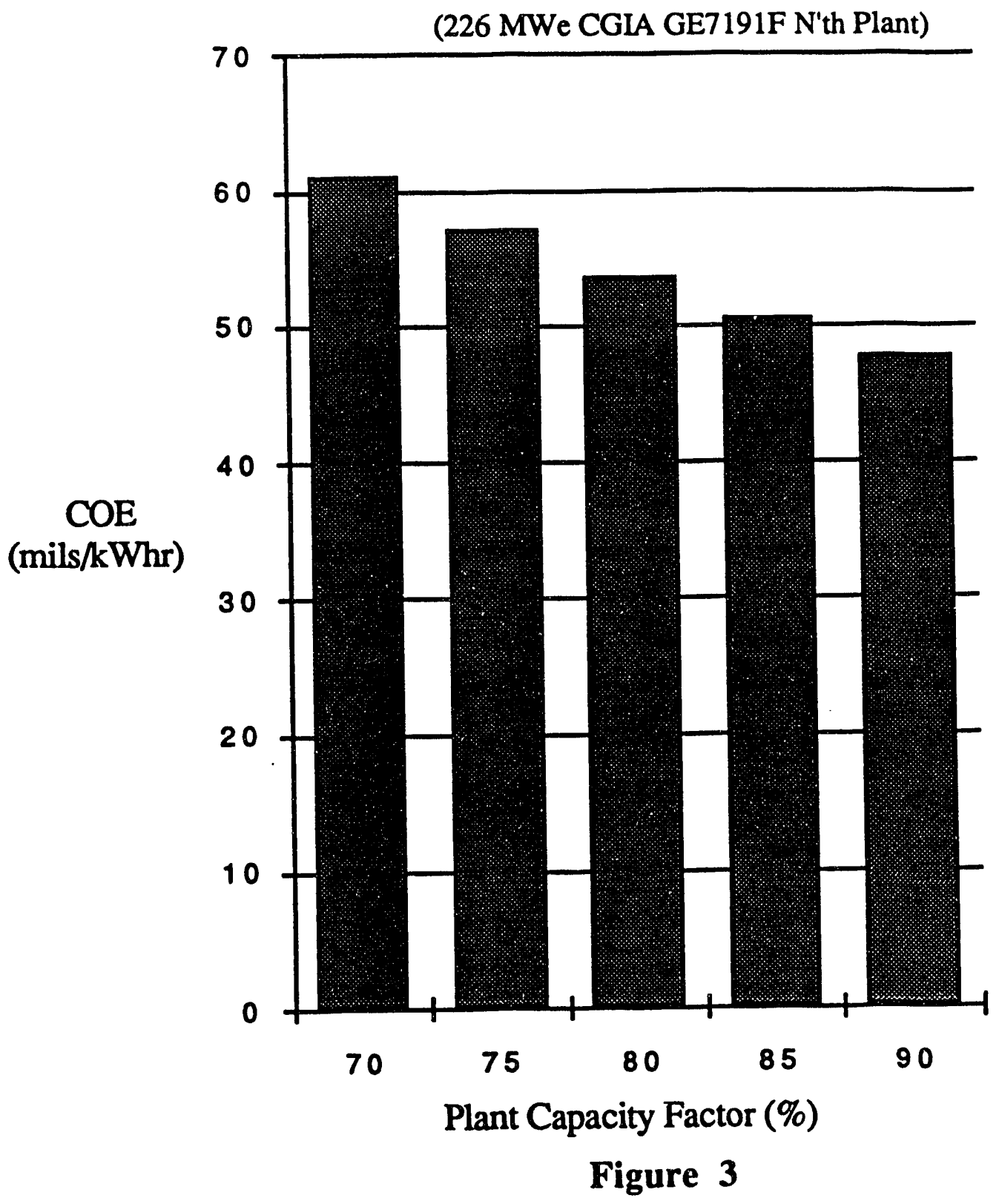

systems selected in shop fabricated truck shippable modules. Their employment of multiple individually oversized pulverizers was done in order to accommodate the well known low availability of pulverizers due to high part wear of grinding elements, and consequent down time. The fruits of their wisdom is readily identifiable in NERC GADS [5] statistical data which shows the forced outage rates 
and total plant unavailability due to pulverizers is almost zero. Based on previous industry experience and projections of new gasifier concepts expected to adequately deal with the adverse consequences of caking and low ash fusion coals, the typical coal throughput of a 14 foot diameter fixed-bed, air-blown gasifier operating at 300450 psi (Figure 4) was subjectively (and somewhat arbitrarily) set at 17 tons per hour. This figure is consistent with Lurgi expectations for Illinois No. 6 coal.

\section{Empirical Gasifier Output Prediction}

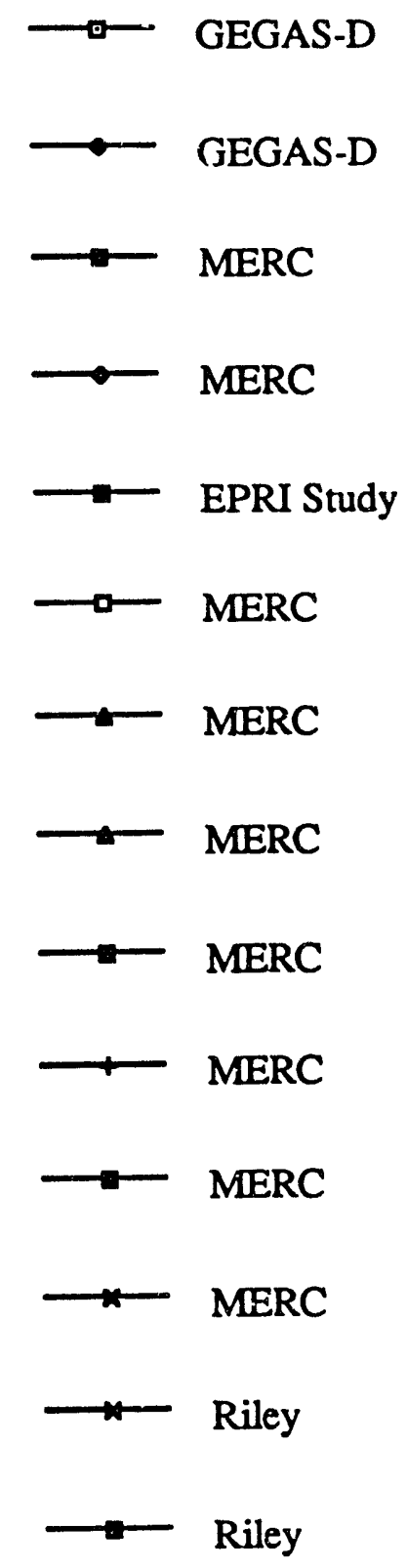

It was determined that it made logical sense to sclect available combustion turbines which when combined with an unfired heat recovery steam generator/turbine set 
(Brayton plus Rankine cycles) would produce power outputs close to the three plant sizes selected for the study. Thus, the three nominal sizes became approximately 45 MWn, $120 \mathrm{MWn}$, and $227 \mathrm{MWn}$, when utilizing GE LM/TG5000PC, ABB GT 11 $\mathrm{N}$, and MW $501 \mathrm{~F}$ combustion turbines respectively.

Initial cost assessments [6][8][9][10] indicated that the smallest plant size was going to be uneconomical due to the relatively high equipment and development costs with respect to power output. It should be noted, however, that the smallest plant also potentially had the highest efficiency. The GE LM/TG $5000 \mathrm{PC}$ which was selected for the $50 \mathrm{MWe}$ case was then reconsidered as a fully Steam Injected Gas Turbine (STIG) con: guration. In this mode it was initially expected that the lower cost of eliminating the steam turbine and higher power output would improve its overall cost effectiveness. It was found that due to the high mass flows of the low BTU coal gas to the turbine combustor, the machine was steam irjut (hence power output) limited by surge margin limitations of its manufacturer. This was especially true when high steam flows to the gasifier were needed. This limitation prompted the consideration of the use of water to the booster compressor inlet in lieu of steam to the gasifier. The net effect of either is to control inlet gas tenperatures, grate temperatures, gasification peak combustion zone temperatures; however, less $\mathrm{H} 2 \mathrm{O}$ is needed to effect the same inlet gas cooling when water spray is used due to its heat of evaporation.

The cumulative results of the study revealed that the plant cost goal of $\$ 1,000 / \mathrm{kW}$ (or less) for the N'th unit can be met at CGIA unit capacities greater than $200 \mathrm{MWe}$ as shown in Figure 5.

The specific results of the analysis for the plant sizes given consideration follow for each nominal size. In addition, a scheme selected for application to existing coal fired utility plants with a low BTU coal gas fired conversion of the coal boiler resulting in a plant efficiency in excess of $40 \%$ follows.

\subsubsection{MW Size for Co-generation \& IPP}

The GE/LM/TG5000PC aeroderivative turbine was initially studied for application as a cogeneration and Independent Power Production (IPP) CGLA candidate. Later, owing to the economic unattractiveness of it as a STAG type unit, its use as a STIG unit was considered. 


\section{Air-Blown Fixed Bed IGCC Plant Costs}

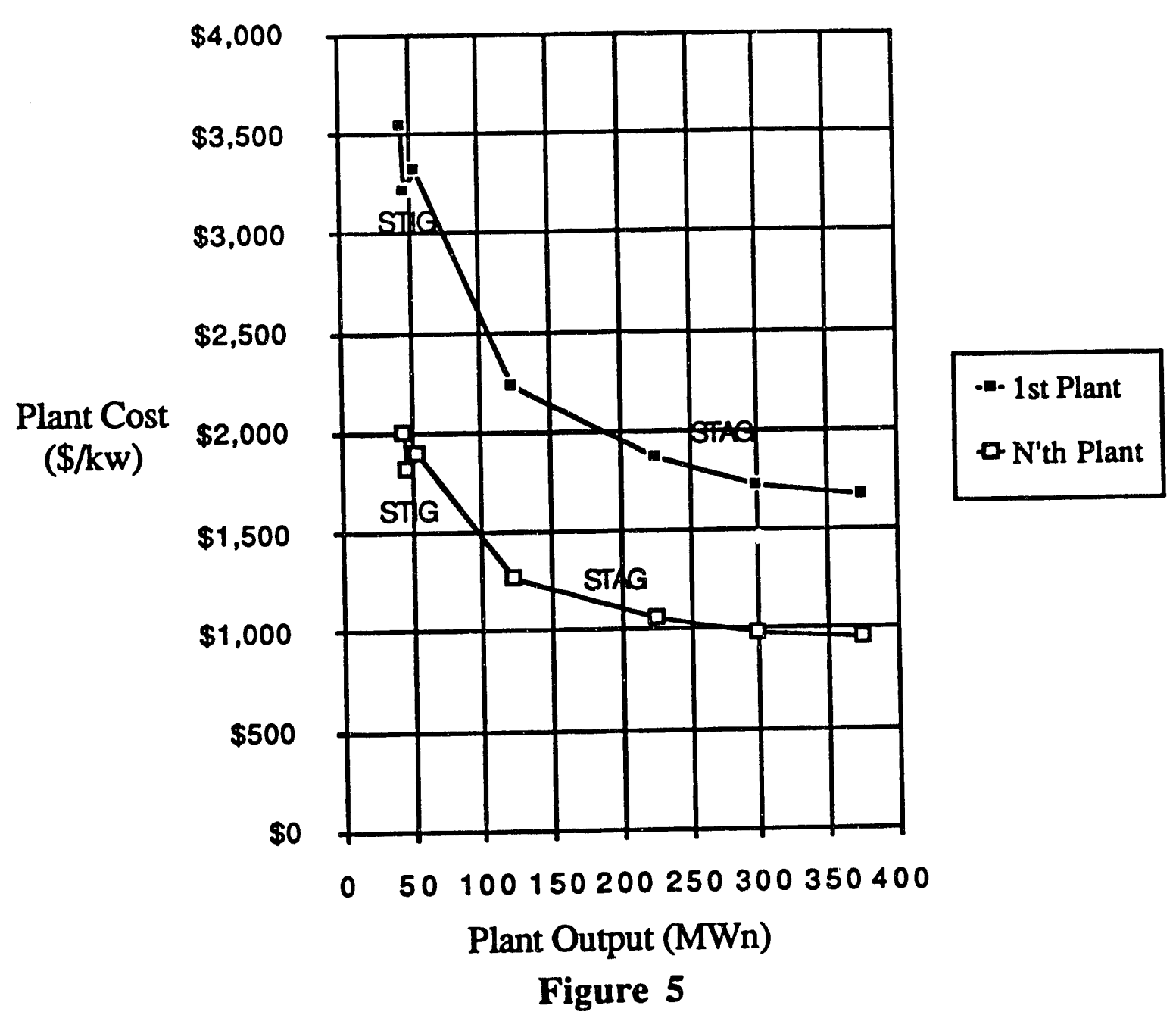

\subsubsection{STAG}

The schematic shown in Figure 6 reflects a basic CGIA concept applied to a cogeneration (cogen) or independent power production (IPP) facility. It utilizes a GE LM/TG5000PC aeroderivative combustion turbine with an unfired heat . 


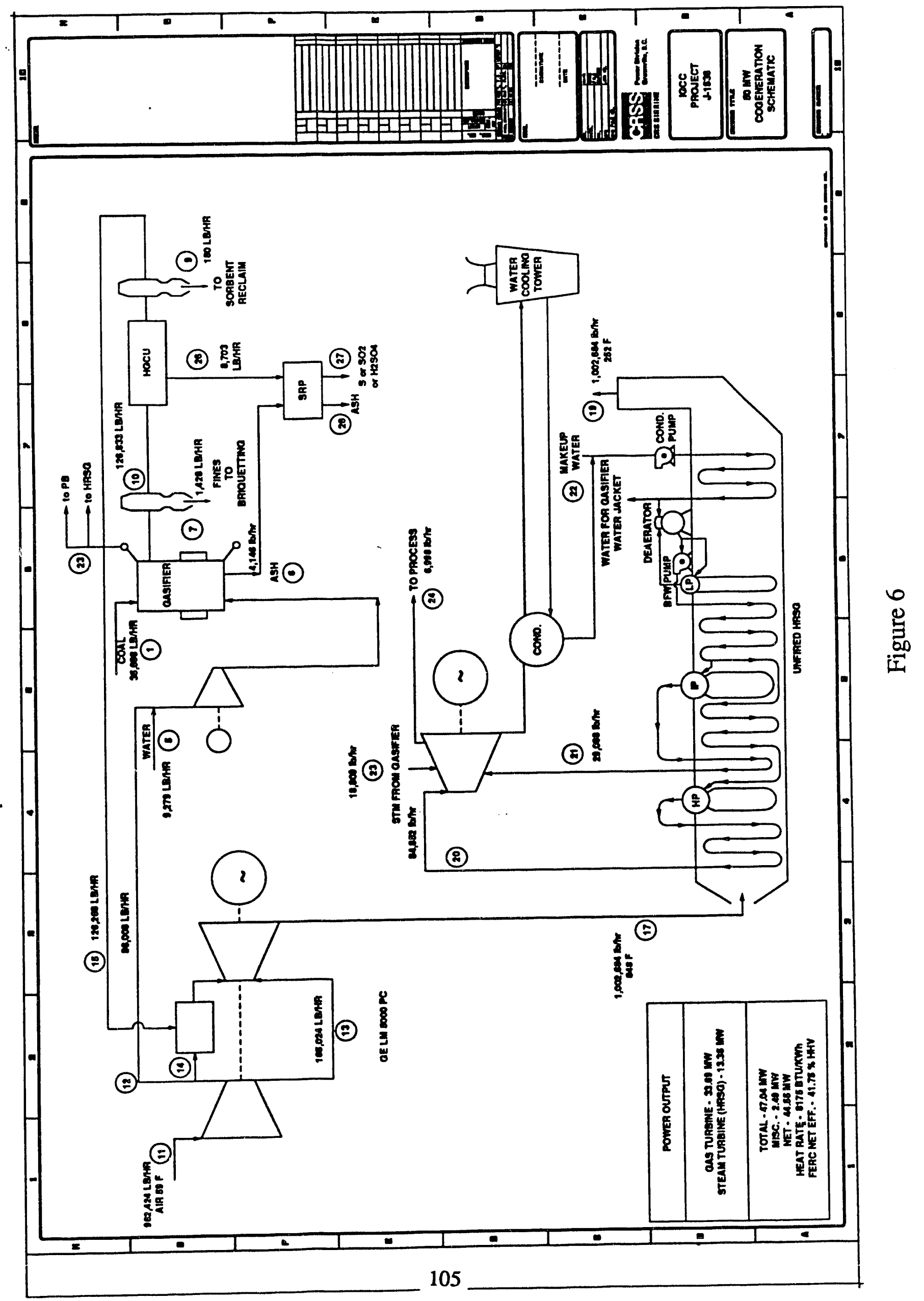


recovery steam generator (HRSG). To meet the year $2000 \mathrm{goal}$ of $0.1 \mathrm{lb} / \mathrm{MBtu}$ NOx emissions, ammonia injection/selective catalytic reduction (SCR) is deemed necessary. Since CGIA employs a zinc ferrite ( $\mathrm{ZnFe}$ ) hot gas cleanup unit (HGCU), the SO2 emission limit goal of $0.1 \mathrm{lb} / \mathrm{MBtu}$ can be met with $99.5 \%$ desulfurization which is consistent with removal efficiencies of current HGCU designs. By the year 2000, such impediments as sulfur bearing tars, and sulfur regeneration/recovery efficiency losses are judged to have been overcome by improved gasifier and HGCU designs.

The nominal $50 \mathrm{MWe}$ plant generates a net output to the grid of $45 \mathrm{MWe}$. A plant cost estimate sensitivity analysis for the N'th plant revealed costs of electricity (COE) (Figure 7) from approximately $9 \notin / \mathrm{kWh}$ to $12 \notin / \mathrm{kWh}$. Clearly, this result is uneconomical.

Its initial facility total costs are estimated at \$159-million (Table 5a). Even applying $N$ th plant reduction factors [7] which lowered its anticipated costs to $\$ 97$ million failed to reduce its costs sufficiently for serious consideration.

A detailed cost analysis appears in Table 5a -5f. The costs were initially estimated for a conventional natural gas-fired combined cycle facility. The added costs of coal gasification were then added to the cogen plant costs. Sources of capital, terms, return rates expected, and ultimate costs of money were determined from costs typical of many small entrepreneurial co-gen \& IPP developers (Table 6). Owner's costs were also included in order to generate ultimate costs of electricity (COE).

A $40 \%$ cost reduction factor was taken for the "Nth" plant to adequately reflect the total effects of modularization, standardization, and replication. Justification comes from having identified such companies as Cogentrix who was able to produce a very low cost (approximately $40 \%$ plant reduction) coal fired power plant using "low tech" and mature technology (stokers). 
Plant Cost Sensitivity GE-LM/TG5000PC 45 MWe CGIA, N'th Plant

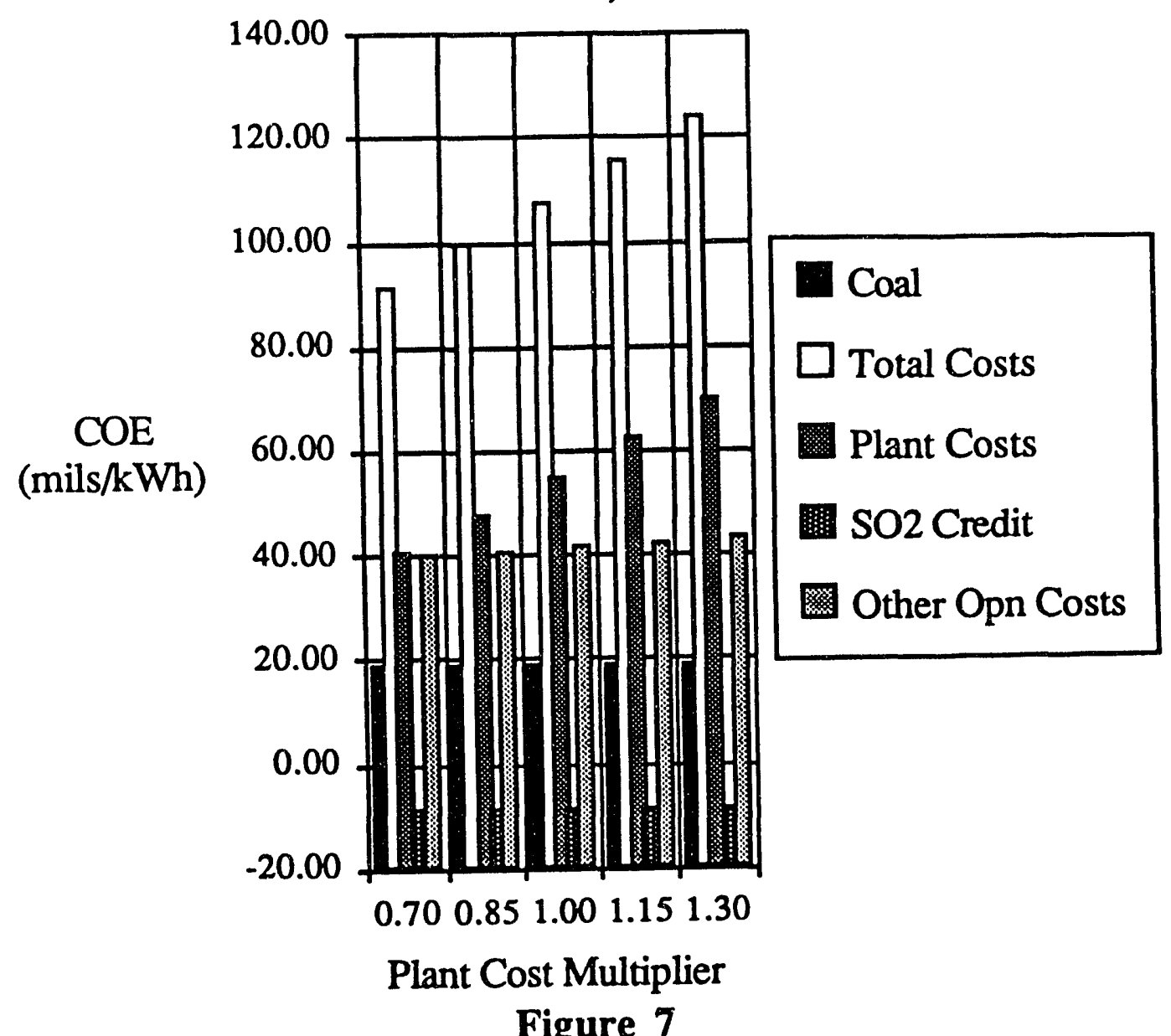

Figure 7 


\begin{tabular}{|c|c|c|c|c|c|}
\hline \multicolumn{6}{|c|}{ 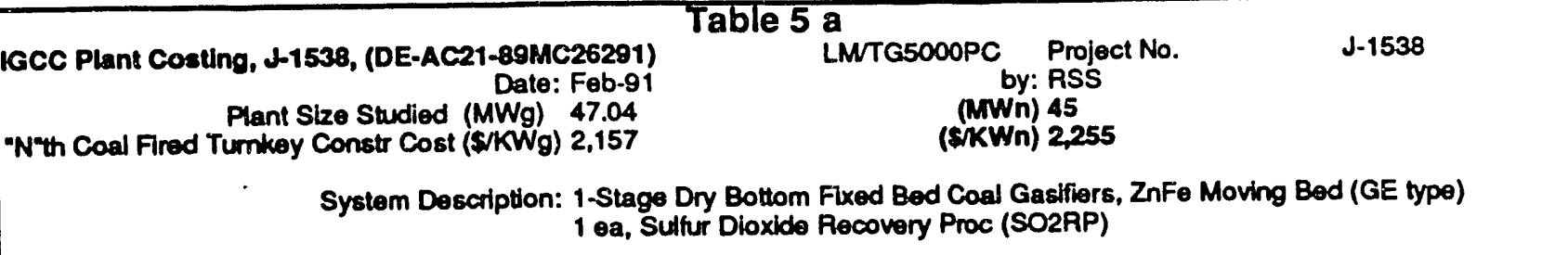 } \\
\hline \multicolumn{2}{|l|}{ Number Trains \& Section Descriotion } & $\begin{array}{l}\text { 1st Plant } \\
\text { SectionCost, }(\$)\end{array}$ & $\begin{array}{l}\text { N-th Plant } \\
\text { Section Cost. }(\$) \\
\end{array}$ & $\begin{array}{l}\text { N-th } N \\
\text { Learning } \\
\text { Reduct } \\
\end{array}$ & $\begin{array}{c}\text { N-th Plant } \\
\text { Cost } \\
\text { (\$N/kwn) }\end{array}$ \\
\hline $\begin{array}{l}1 \text { ea, Coal Handling } \\
1 \text { ea, Briquelting System } \\
2 \text { ea, Gasification \& Ash } \\
1 \text { ea, Hot Gas Cleanup System (GE typo) } \\
1 \text { ea, Gas Turbine } \\
1 \text { ea, HRSG, (Includes CO Catalyst \& SCR) } \\
1 \text { ea, Steam Turbine } \\
1 \text { ea, Booster Compressor } \\
1 \text { ea, Sulfur Dioxide Recovery Proc (SO2RP) }\end{array}$ & $\begin{array}{c}7200 T P D \\
2400 \mathrm{TPD} \\
36-\mathrm{Ib} / \mathrm{sec} \\
36-\mathrm{Ib} / \mathrm{sec} \\
\text { LM/TG5000PC } \\
24-\mathrm{lb} / \mathrm{sec} \\
14 \mathrm{MWO} \\
25-\mathrm{Ib} / \mathrm{sec} \\
2 \mathrm{~K}-\mathrm{lb} / \mathrm{hr}\end{array}$ & $\begin{array}{c}4,895,156 \\
3,207,625 \\
17,213,738 \\
8,635,578 \\
19,828,125 \\
7,883,016 \\
6,024,688 \\
900,000 \\
4,387,500\end{array}$ & $\begin{array}{c}4,895,156 \\
2,566,100 \\
13,770,990 \\
5,181,347 \\
15,862,500 \\
7,883,016 \\
6,024,688 \\
900,000 \\
2,632,500\end{array}$ & $\begin{array}{l}(\%) \\
0 \\
20 \\
20 \\
40 \\
20 \\
0 \\
0 \\
0 \\
40\end{array}$ & $\begin{array}{c}109 \\
57 \\
306 \\
115 \\
353 \\
175 \\
134 \\
20 \\
59\end{array}$ \\
\hline Sub-total & & $72,975,426$ & $59,716,297$ & & 1,327 \\
\hline BalancoofPlant( $\%$ sub-i w/out proc conting) & $37 \%$ & $26,878,255$ & $16,126,953$ & 40 & 358 \\
\hline TOTAL PROCESS CAPITAL & & $99,853,681$ & $75,843,250$ & & 1,685 \\
\hline Fully Standardized Designed N'th Plant & & & $59,912,209$ & 40 & 1,331 \\
\hline $\begin{array}{l}\text { Engineering (Onfy) } \\
\text { Enginoering (Contractor's) Fees } \\
\text { (Inct Proj\&ConstMgt, Testing/Startup, Design/Buile } \\
\text { (\%orTotal Process Capital) }\end{array}$ & $\begin{array}{l}2 \% \\
22 \% \\
\text { Hld Contr Fees, but I }\end{array}$ & $\begin{array}{l}22,347,433 \\
\text { NOT Opn, Data Col }\end{array}$ & $\begin{array}{l}13,408,460 \\
\text { A. Rptg, Admin, Dspsn) }\end{array}$ & 40 & 298 \\
\hline $\begin{array}{l}\text { Project Contingency } \\
\text { (\%oofTotal Procoss Capltal) }\end{array}$ & $13 \%$ & $12,880,879$ & $7,788,587$ & 40 & 173 \\
\hline TOTAL PLANT INVESTMENT & & $135,182,093$ & $81,109,256$ & & 1,802 \\
\hline $\begin{array}{l}\text { Allowance for Funds During Construction, } \\
\text { (AFDC) }\end{array}$ & $13 \%$ & $12,755,000$ & $7,653,000$ & & 170 \\
\hline $\begin{array}{l}\text { WorkCap,Taxes,Royal,Devel,Permitts,Logal, } \\
\text { Fuel Inven, Spare Parts, Underwiter Costs }\end{array}$ & $10 \%$ & $10,372,271$ & $7,900,963$ & & 176 \\
\hline $\begin{array}{l}\text { Land(Historical SiteCostsforCo-generation) } \\
\text { Acreage @ } \$ 8,500 \text { per Acre }=49\end{array}$ & $0.3 \%$ & 418,000 & 418,000 & & 9 \\
\hline TOTAL CAPITAL REQUIREMENT & & $158,727,364$ & $97,081,219$ & & 2,157 \\
\hline
\end{tabular}




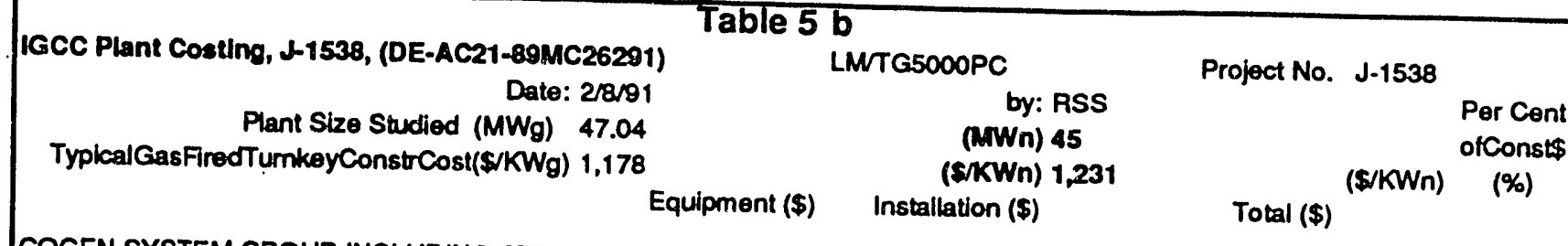

COGEN SYSTEM GROUP INCLUDING STRD CONTROLS, ELECTRICAL, BLDG, CIVIL, STRUCT, ARCHETEC, MECHAN
Gas Turbine/Gen Syst(Inct Cogen PIt I8C) $\$ 11,406,250$

Steam Turbine/Generator System

StartUp\&BackupFuel(NatGas)PrepSystem

Condenser \& Vacuum Systems

$\$ 4,634,375$

$\$ 571,250$

$\$ 529,375$

TURBINE ISLAND

$\$ 17,141,250$

$\$ 5,130,379$

$\$ 22,271,629 \quad 495$

18

Aux Bir for Startup/Emerg PwrGen (Optional)

HtRecovSteam Generator(w/COCatyl\&SCR)

$\$ 5,828,125$

HRSG Ductwork \& Stack (Incl)

$\$ 2,124,977$

$\$ 0$

$\$ 5,828,125$

$\$ 2,054,891$

$\$ 7,953,102$

Cooling Tower

Evaporative Makeup,Circ Water,\&AuxSys

SUB TOT COOL'G TWR SYST

$\$ 763,125$

$\$ 268,278$

$\$ 1,031,403$

23

0.8

Raw Water Woll, Pumps, Fire Prot System

Demineralizer, Treatment \& Storage

Treated Water Pumping \& Control

CondensateRet, WalerChem, Filt, StorTanks

Chem Treat \& Cooling Systems

Foed Water Heaters\&Deaerator

FEEDWATER \& WATER TREATMENT SYST

Generation Plant Eloctrical System (ind)

Sub Station,X-Imrs, Switchyard (Inc)

and Balance of Plant Eloctrical

Power Transmission Lines

SUB TOT ADDTIONAL ELECTRIC SYSTEM

DistribydContrSyst(DCS),CentrCnerFacility

Emissions Monitors(Additional)

INSTRUMENTATION\&CONTROL SYSTEMS

BUILDINGS (Contr Rm,Lav,HVAC,CompAir)

PAINTING/INSULIAGG'G/SCAFFOLDING

COGENERATION SYST SUB TOTAL

$\$ 634,543$

$\$ 2,571,106$

57

2

$\$ 3,993,750$

$\$ 220,000$

$\$ 4,213,750$

$\$ 880,000$

$\$ 2,855,106$

$\$ 7,068,856$

157

6

$\$ 1,956,250$

$\$ 595,538$

$\$ 2,551,788$

57

2.1

$\$ 662,500$

$\$ 320,601$

$\$ 983,101$

$\$ 150,000$

$\$ 45,664$

$\$ 195,664$

$\$ 32,651,563$

$\$ 11,905,000$

$\$ 44,556,563$

990

36

ADD.DESIGN ENGINEERING@8\%

$\$ 3,564,525$

$\$ 3,564,525$

ADD. PROJECT MANAGEMENT@3\%

$\$ 891,131$

$\$ 891,131$

ADD. CONSTRUCTION MGT@3\%

ADD. TESTG @1\% (2\% tost\&strtup)

ADD. START UP COSTS @ $1 \%$

$\$ 445,566$

$\$ 1,336,697$

$\$ 1,336,697$

$\$ 445,566$

$\$ 445,566$

$\$ 445,566$

ADD. DES/BUILD CONTR'S FEE@7\%

$\$ 1,782,263$

$\$ 1,782,263$

SUB TOT INDIRECT COSTS

$\$ 7,129,051$

$\$ 1,336,697$

$\$ 8,465,748 \quad 188$

7

$\$ 39,780,614$

$\$ 13,241,697$

$\$ 53,022,311$

1,178 


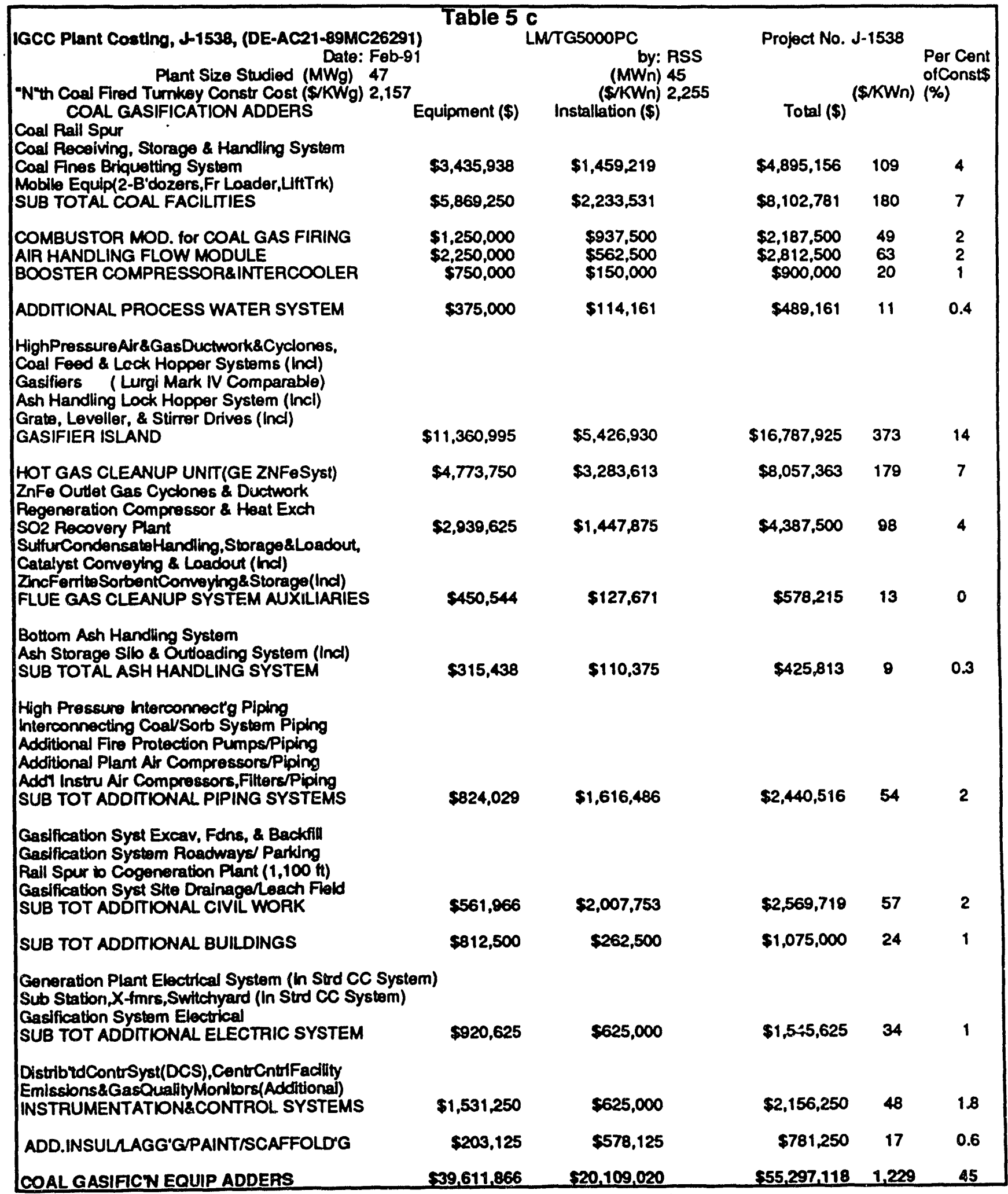




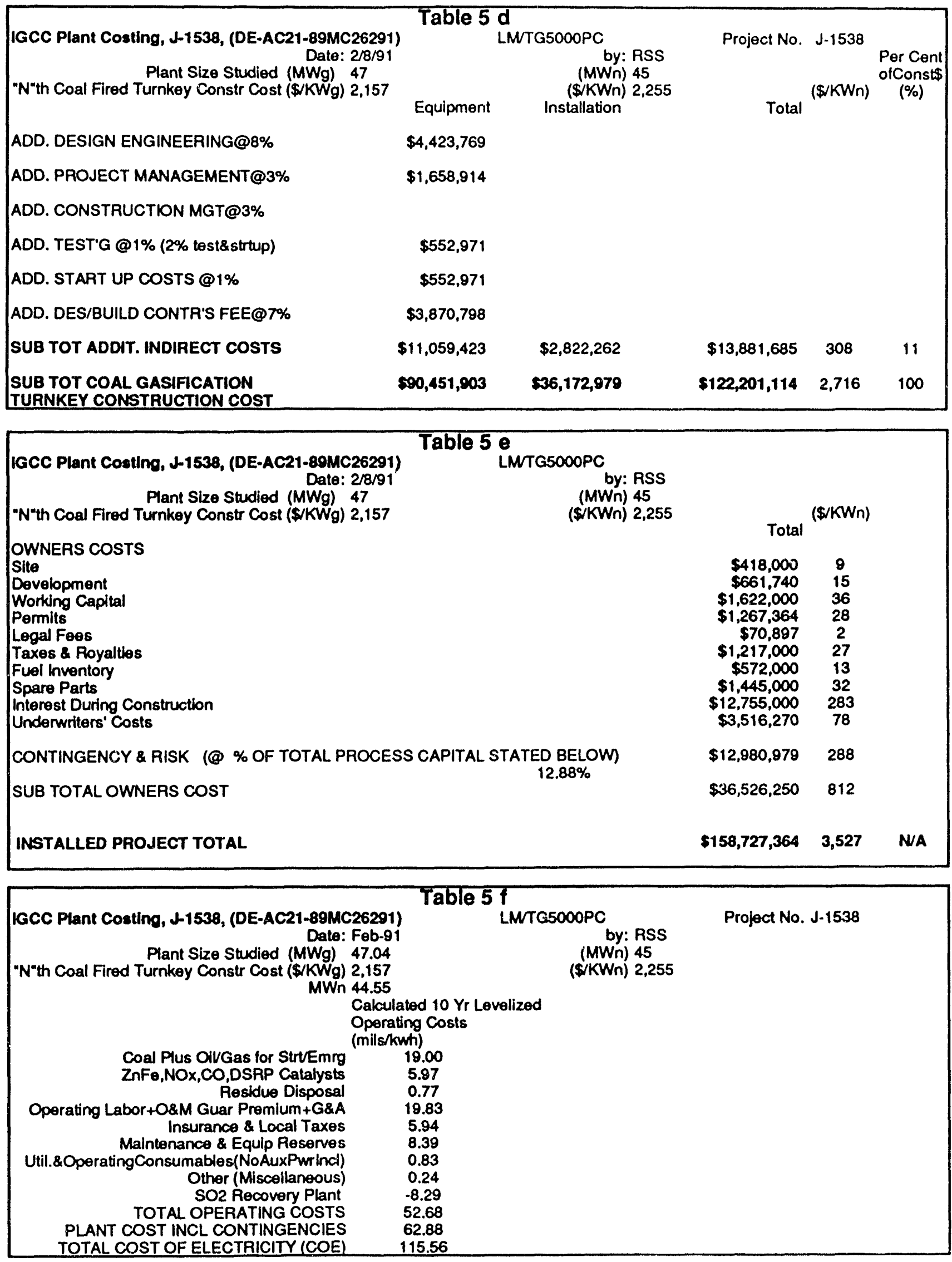




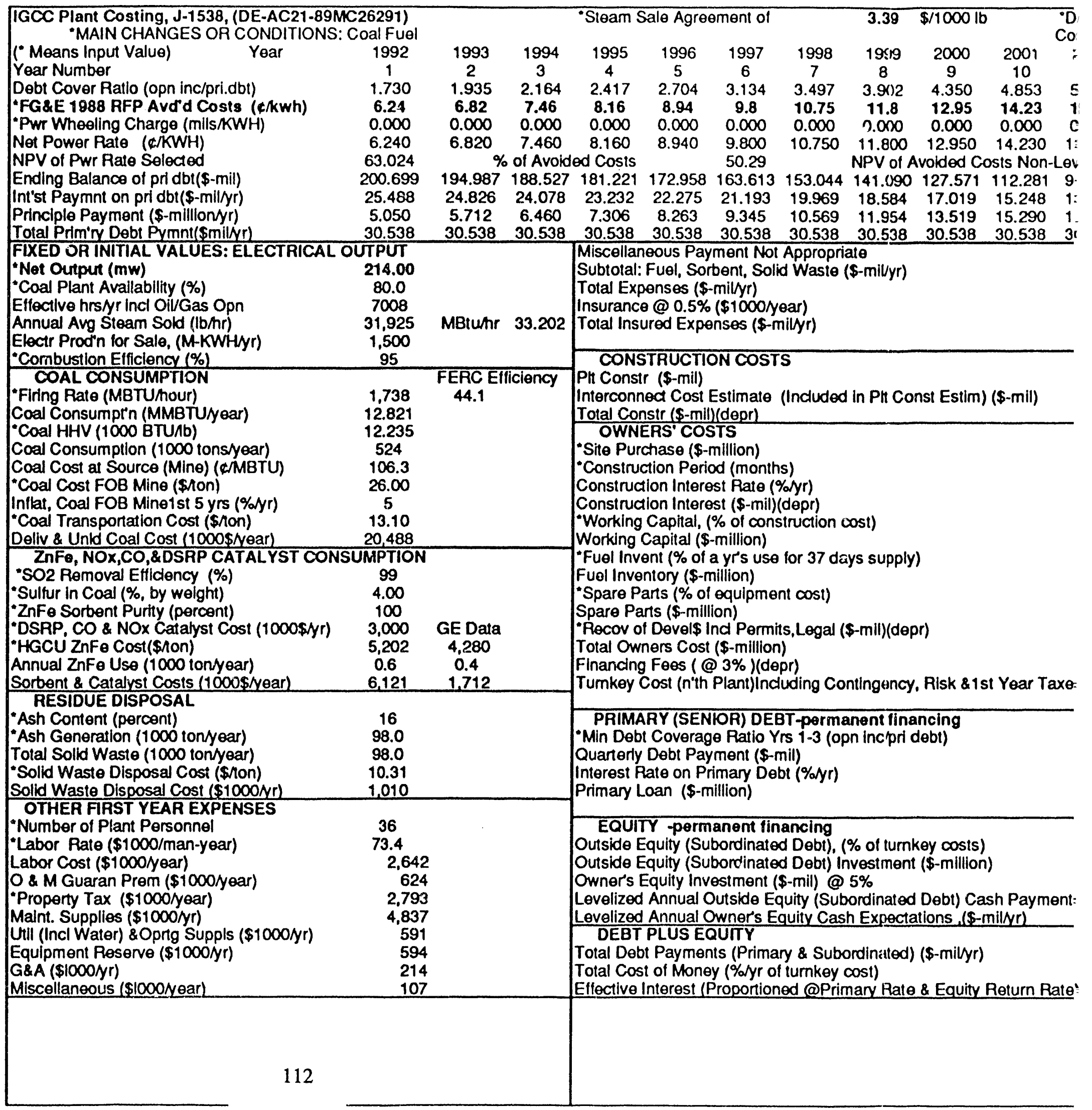




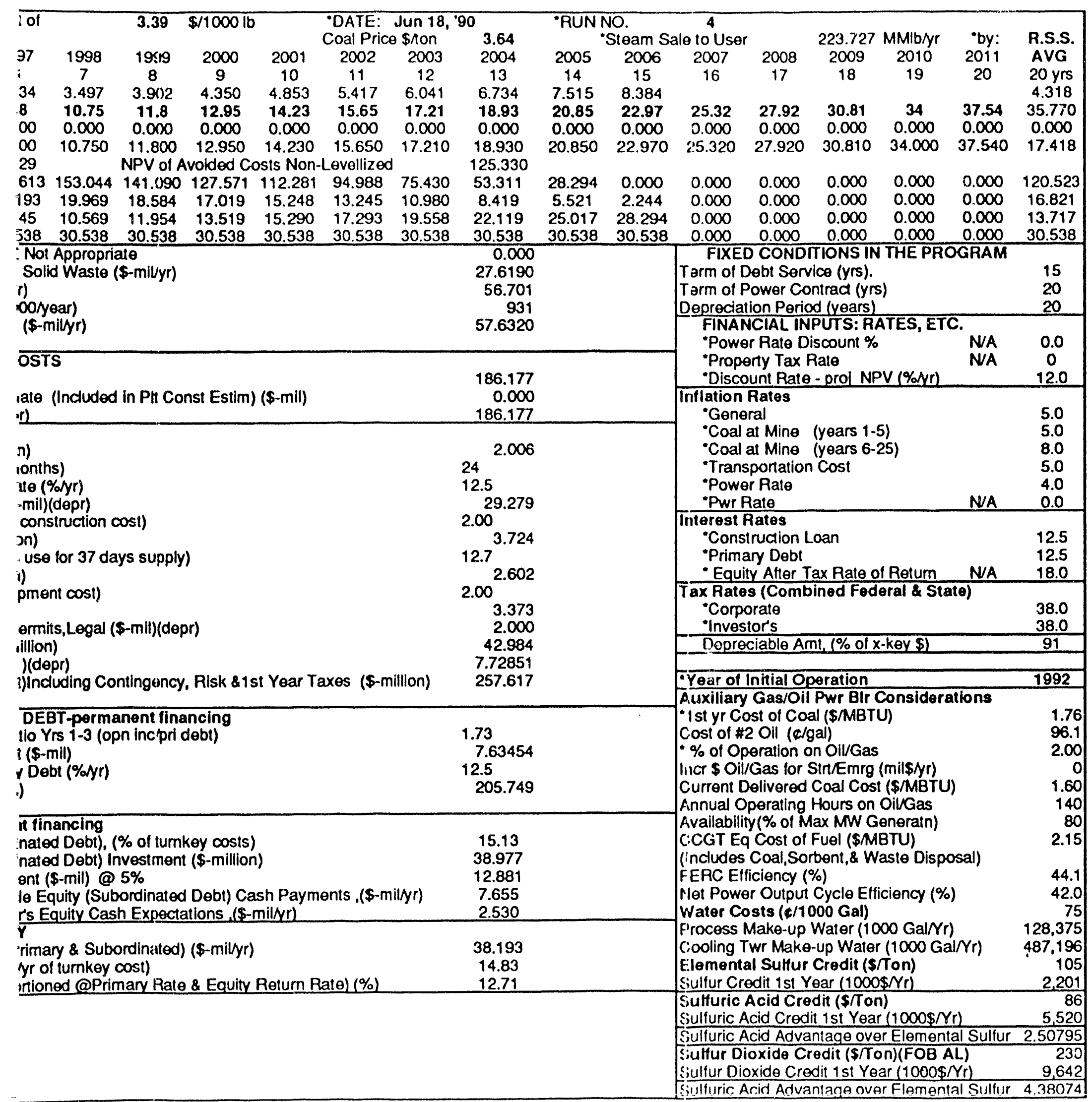




\subsubsection{STIG}

The schematic shown in Figure 8 reflects a basic CGIA concept applied as a STIG unit tc a cogeneration (Cogen) or independent power production (IPP) facility. It utilizes a SE LM 5000 ST 120 aeroderivative combustion turbine with an unfired heat recovery steam generator (HRSG), however, it does not employ a steam turbine/generator. Its HRSG generated steam is partially injected into the combustion turbine (to its compressor surge margin limits) increasing its output, and the balance of steam generated is available for process use.

To meet the year 2000 goal of $0.1 \mathrm{lb} / \mathrm{MBtu}$ NOx emissions, ammonia injection/selective catalytic reduction (SCR) is deemed necessary.

Since CGIA employs a zinc ferrite ( $\mathrm{ZnFe}$ ) hot gas cleanup unit (HGCU), the $\mathrm{SO} 2$ emission limit goal of $0.1 \mathrm{lb} / \mathrm{MB}: \mathrm{u}$ can be met with $99.5 \%$ desulfurization which is consistent with removal efficiencies of current HGCU designs. By the year 2000, such impediments as sulfur bearing tars, and sulfur regeneration/recovery efficiency losses are judged to have been overcome by improved gasifier designs and HGCU's.

The nominal $50 \mathrm{MWe}$ plant generates a net output to the grid of $47 \mathrm{MWe}$. A plant cost estimate sensitivity analysis for the $N$ 'th plant revealed costs of electricity (COE) (Figure 9) from approximately $8 \notin / \mathrm{kWh}$ to $11 \notin / \mathrm{kWh}$. Clearly, this result is also uneconomical almost irrespective of the value of the process steam.

Its initial facility total costs are estimated at \$136-million (Table 7a). Even applying $N$ th plant reduction factors (7) which lowered its anticipated costs to $\$ 83$ million failed to reduce its costs sufficiently for serious consideration.

A detailed cost analysis appears in Tables $7 \mathrm{~b}-7 \mathrm{f}$. The costs were initially estimated for a conventional natural gas-fired combined cycle facility. The added costs of coal gasification were then added to the co-gen plant costs. Sources of capital, terms, return rates expected, and ultimate costs of money were determined from costs typical of many small entrepreneurial cogen \& IPP developers (Table 6). Owner's costs were also included in order to generate ultimate costs of electricity (COE). 


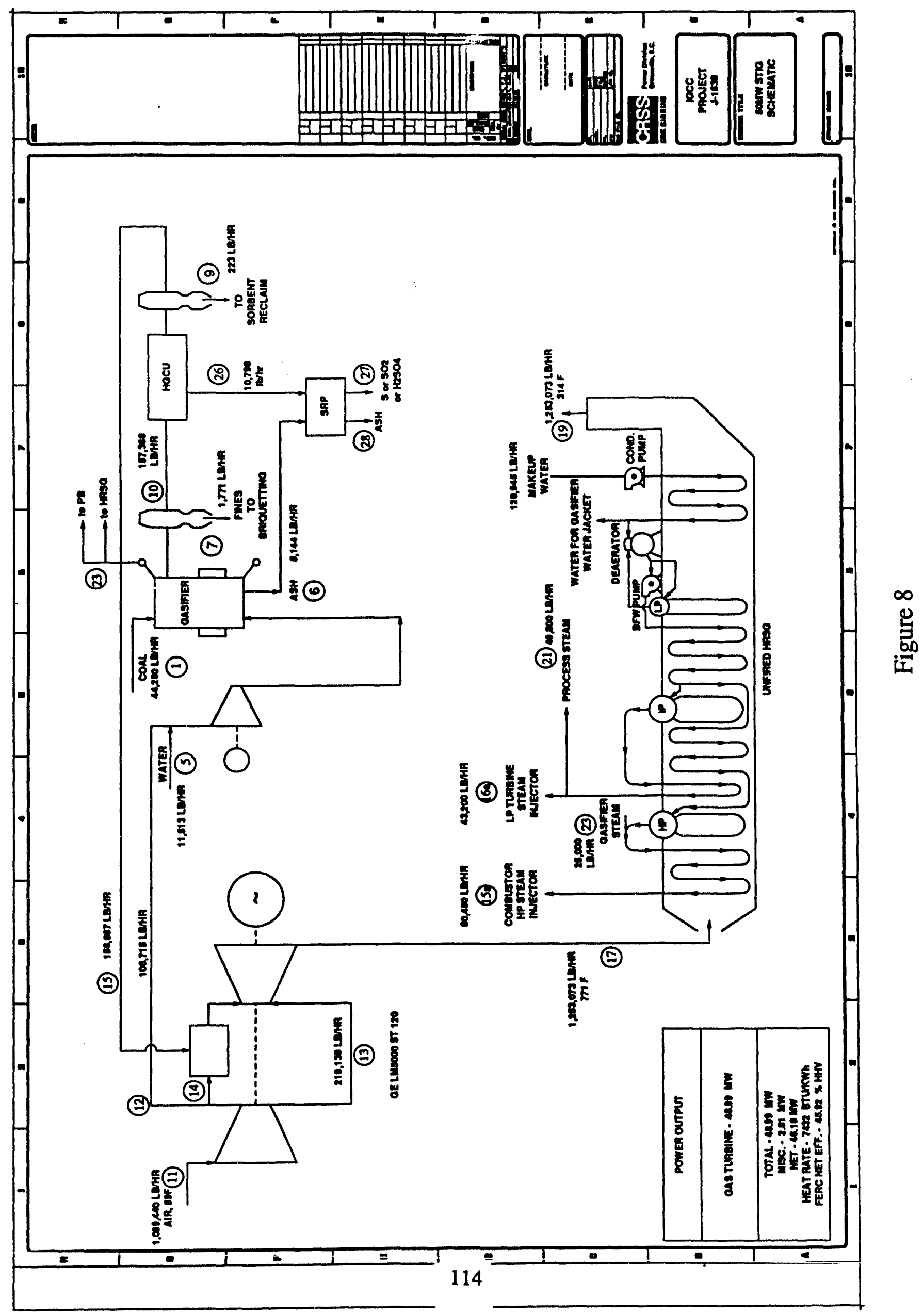




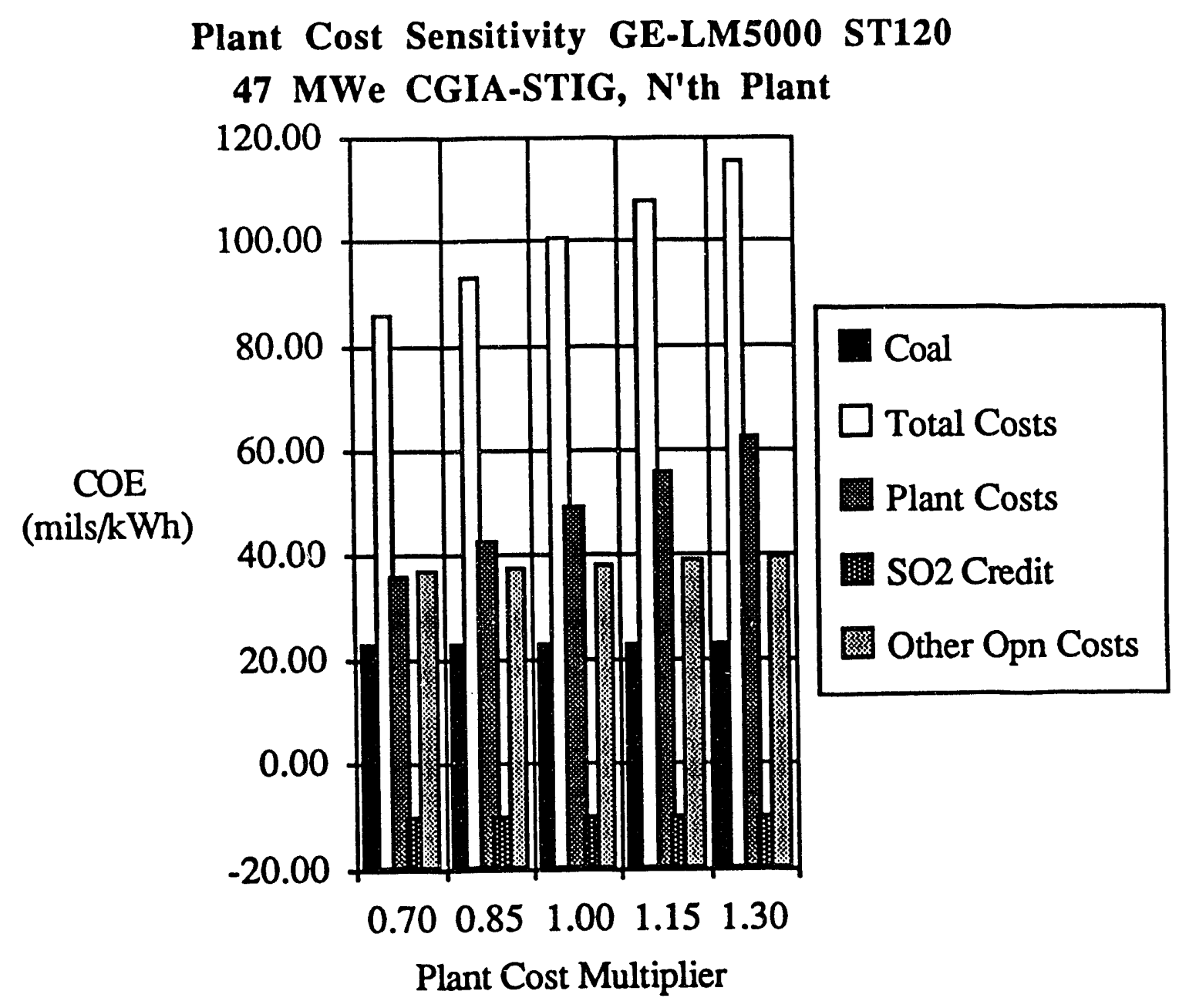

Figure 9 


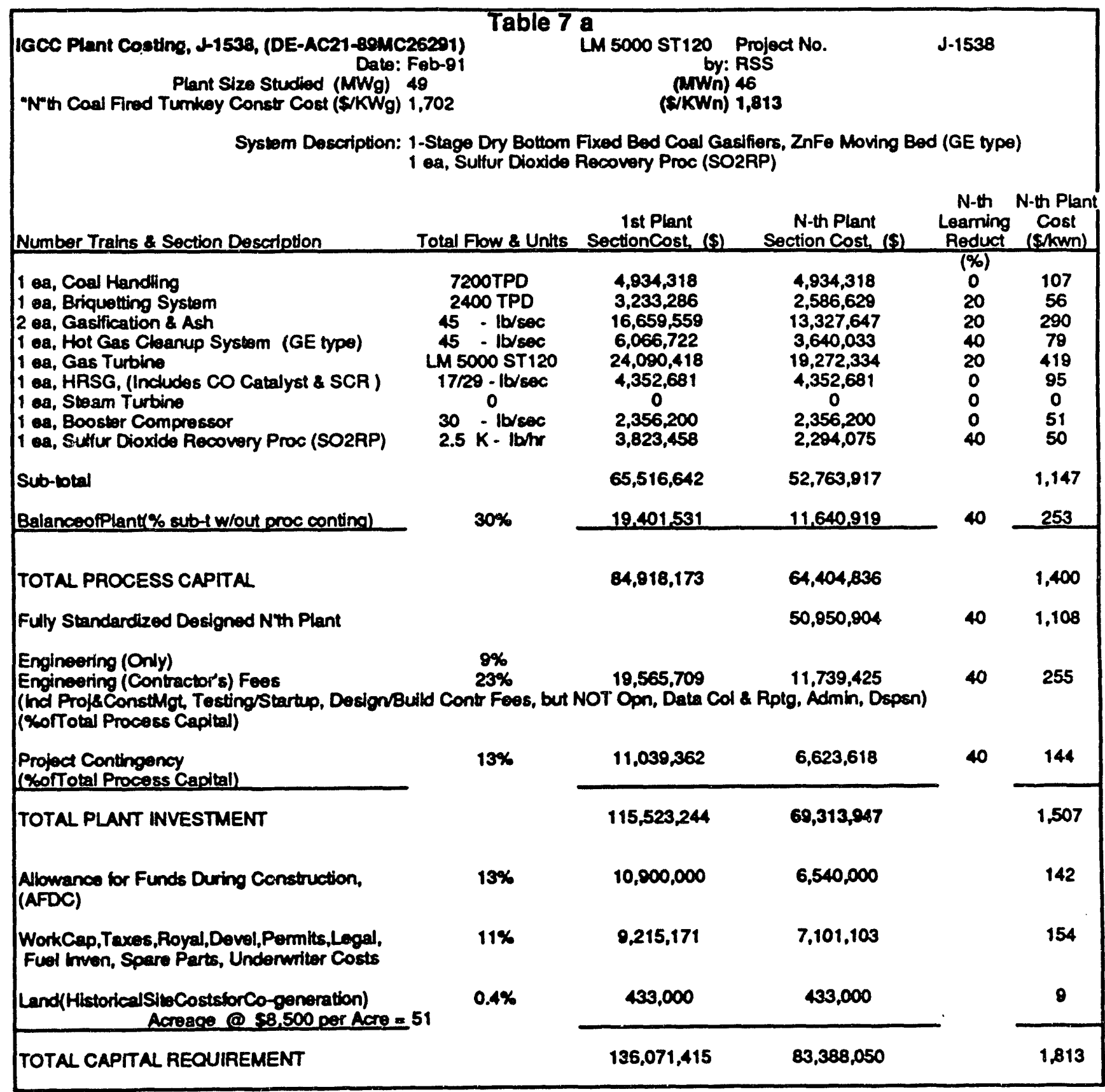




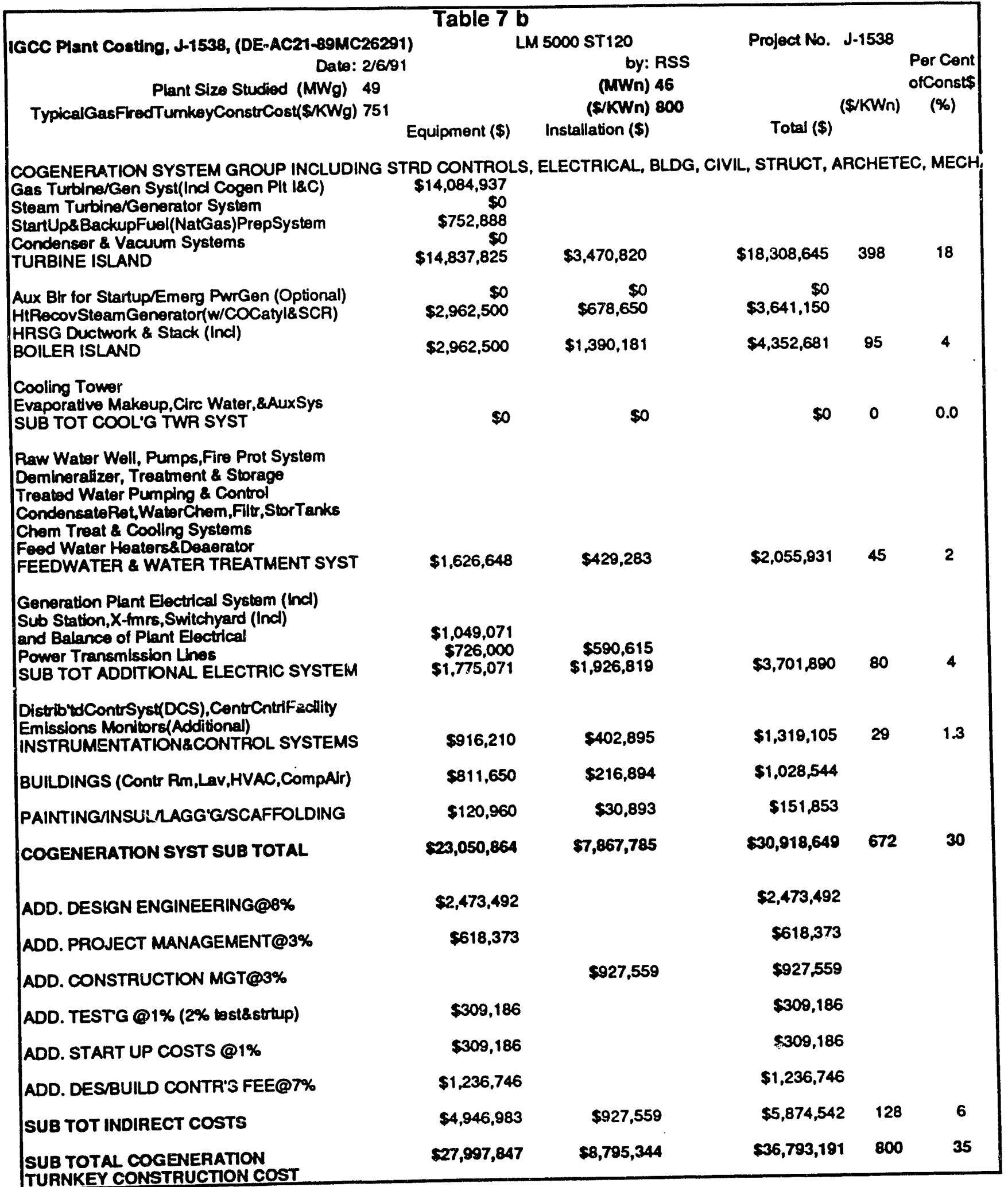




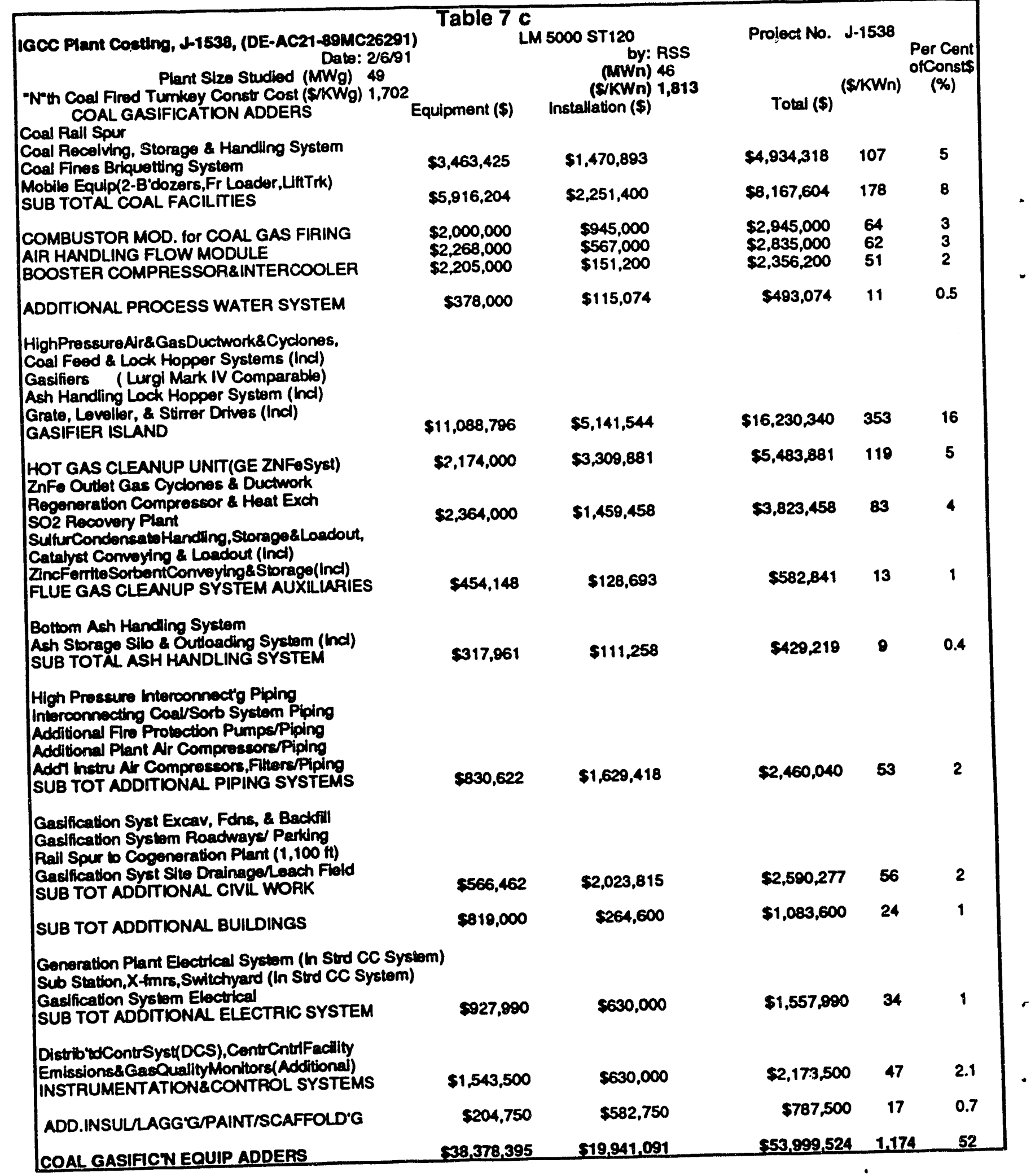




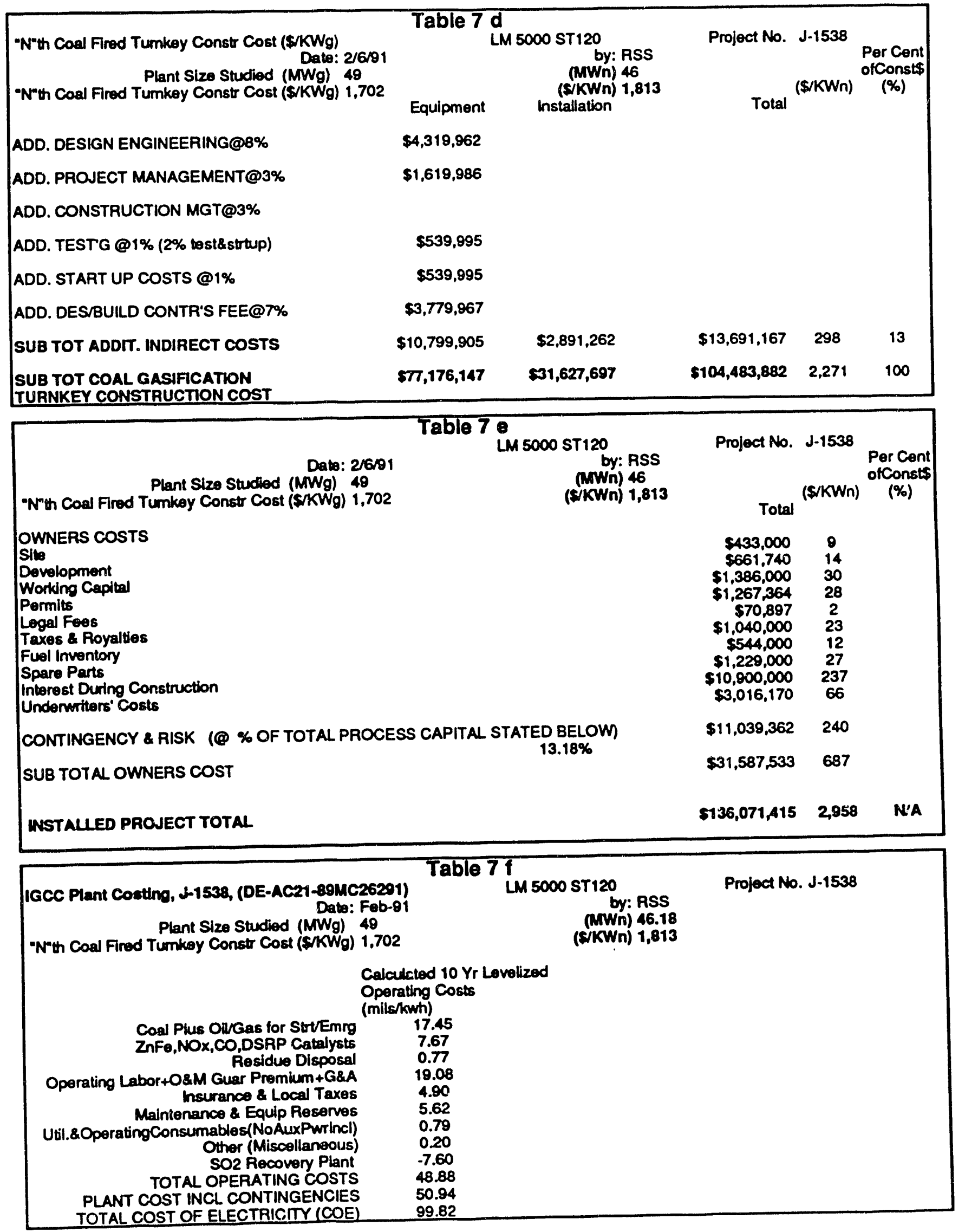




\subsubsection{Cost Sensitivity}

There appears to be little chance of making such a small capacity plant economical (Figure 7). The plant cost estimate sensitivity analysis for the $N$ 'th plant revealed costs of electricity (COE) from approximately $9 \notin / \mathrm{kWh}$ to $12 \notin / \mathrm{kWh}$. Even a switch to a STIG configuration did not improve the plant economics enough (the plant cost estimate sensitivity analysis for the $N$ 'th plant revealed costs of electricity [COE] [Figure 9] from approximately $8 \mathrm{c} / \mathrm{kWh}$ to $11 \mathrm{c} / \mathrm{kWh}$ ) to warrant serious consideration of such a small plant. Clearly, this result is also uneconomical almost irrespective of the value of the process steam.

\subsection{2. $100 \mathrm{MW}$ Size CGIA Concept}

Since it is anticipated that the $100 \mathrm{MWe}$ capacity should be a "building block" modular capacity from which both the cogen/PP and utility industries can produce CGIA standardized plants, this capacity was studied for both considerations.

\subsubsection{Cogeneration \& IPP Applications}

The schematic shown in Figure 10 reflects a basic CGIA concept applied as a STAG unit to a cogeneration (Cogen) or independent power production (IPP) facility. It utilizes a GE 7111EA combustion turbine with an unfired heat recovery steam generator (HRSG), and a steam turbine/generator. Its HRSG generated steam is utilized to generate power with $5 \%$ of its thermal output reserved for process use.

To meet the year 2000 goal of $0.1 \mathrm{lb} / \mathrm{MBtu}$ NOx emissions, ammonia injection/selective catalytic reduction (SCR) is deemed necessary.

Since CGIA employs a zinc ferrite ( $\mathrm{ZnFe}$ ) hot gas cleanup unit (HGCU), the SO2 emission limit goal of $0.1 \mathrm{lb} / \mathrm{MBtu}$ can be met with $99.5 \%$ desulfurization which is consistent with removal efficiencies of current HGCU designs. By the year 2000, such :mpediments as sulfur bearing tars, and sulfur regeneration/recovery efficiency losses are judged to have been overcome by improved gasifier designs and HGCU's. 


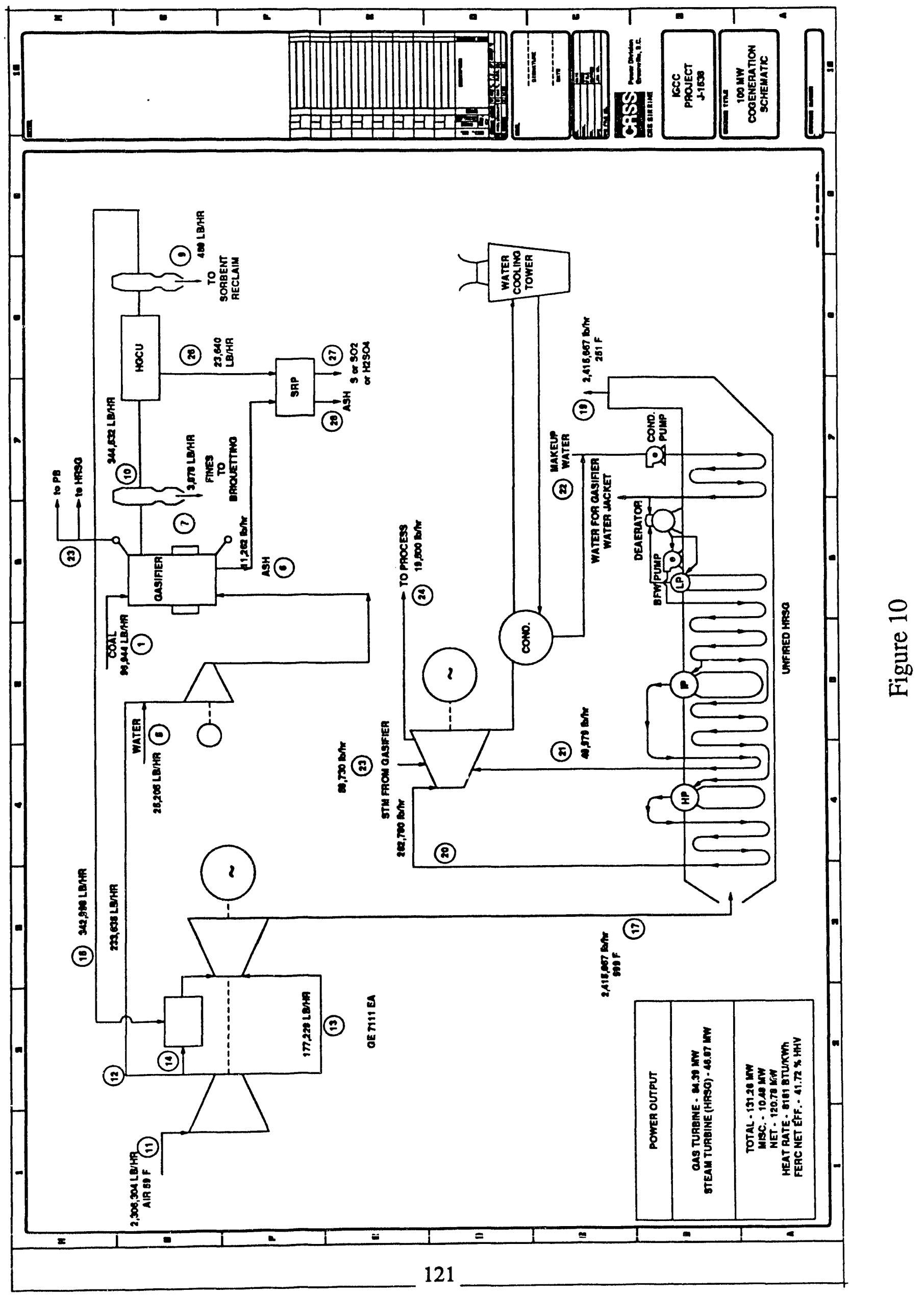


The nominal $100 \mathrm{MWe}$ plant generates a net output to the grid of 120-123 MWe. A plant cost estimate sensitivity analysis for the $N$ th plant revealed costs of electricity (COE) (Figure 11) from approximately $5 \varnothing / \mathrm{kWh}$ to $7 \notin / \mathrm{kWh}$. This result would be acceptable for applications in high power cost areas such as the northeast.

Its initial facility total costs are estimated at \$262-million (Table 8). Applying N'th plant reduction factors [7] which lowered its anticipated costs to $\$ 160$-million reduces its costs sufficiently for serious consideration.

A detailed cost analysis appears in Table 8a - 8f. As in the previous cases, the costs were initially estimated for a conventional natural gas fired combined cycle facility. The added costs of coal gasification were then added to the cogen plant costs. Sources of capital, terms, return rates expected, and ultimate costs of money were determined from costs typical of many small entrepreneurial cogen \& IPP developers (Table 6). Owner's costs were also included in order to generate ultimate costs of electricity (COE).

\subsubsection{Utility Applications}

In an effort to determine its applicability to utility industry, the same cycle was reworked (Figure 12) at the same higher pressures and temperatures (relative to the previous $50 \mathrm{MWe}$ case) which are in line with utility practice. In this case there was no process steam included, and all steam generated from the unfired HRSG was utilized to generate power.

The result, as expected, was only a slight increase in power output over the previous case. This was caused by the anticipation of only minimal thermal use (5\%) in the cogen/IPP case, and both cases are limited in the Rankine cycle conditions by the low thermal head of the unfired HRSG. 


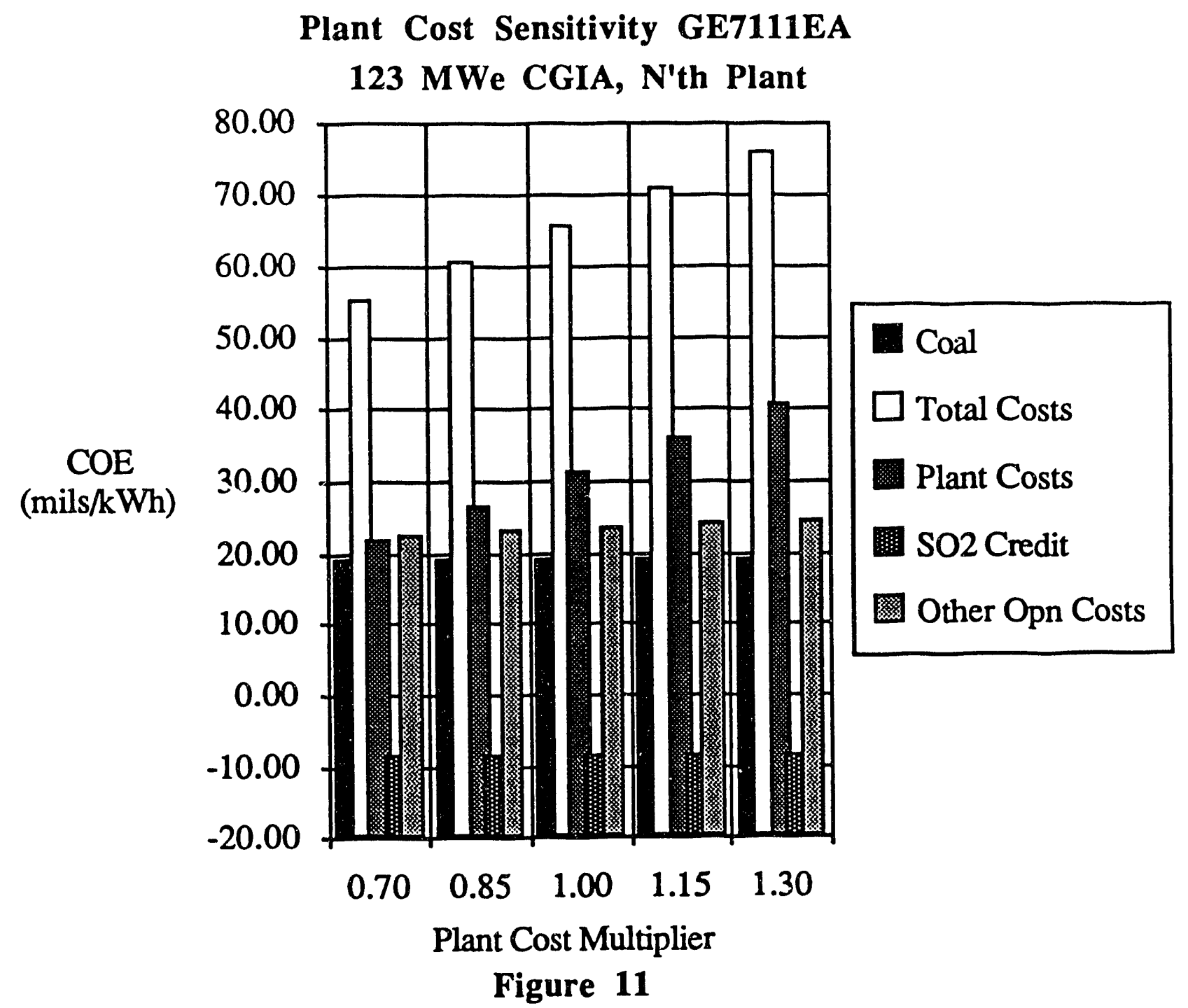




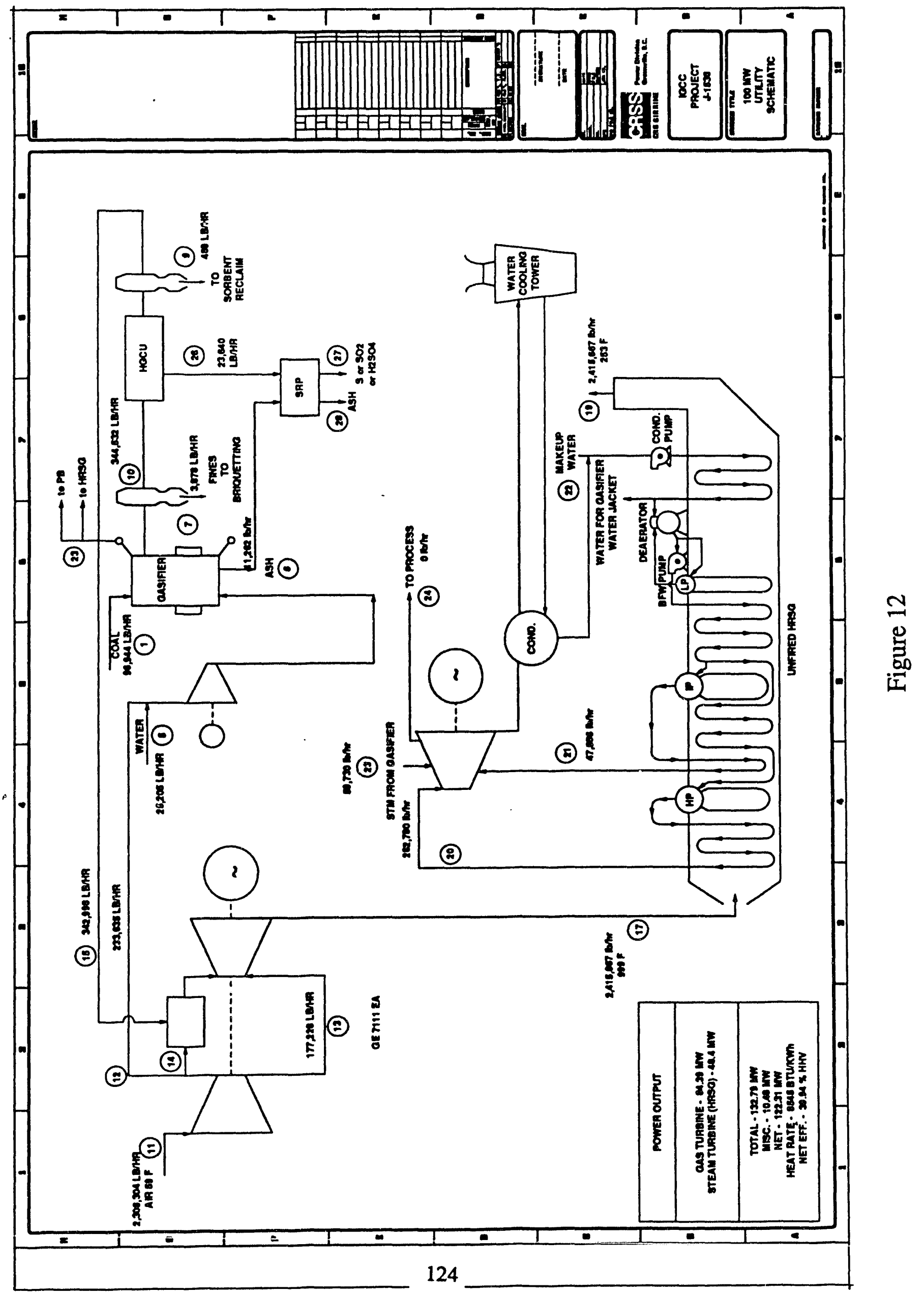




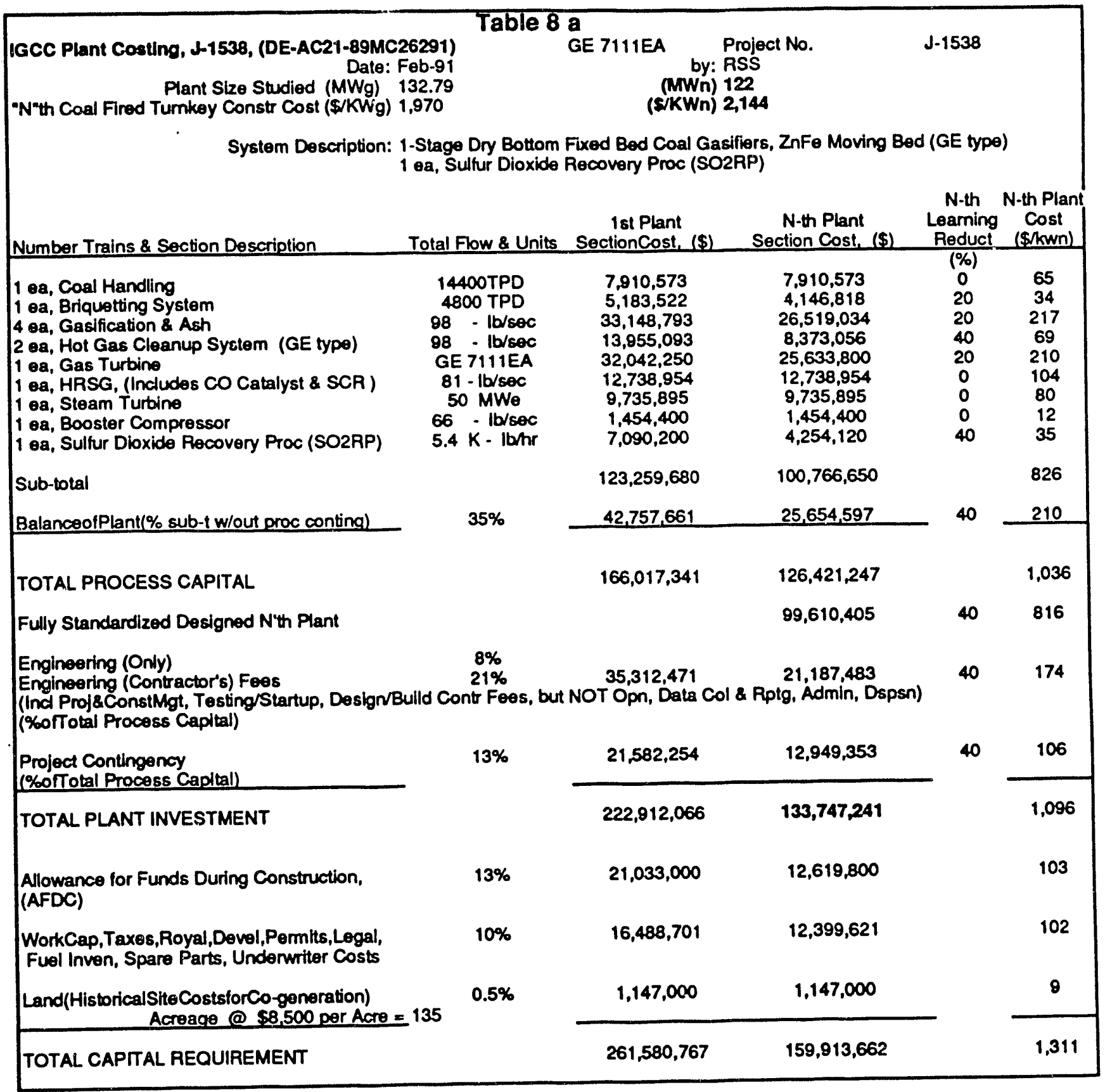




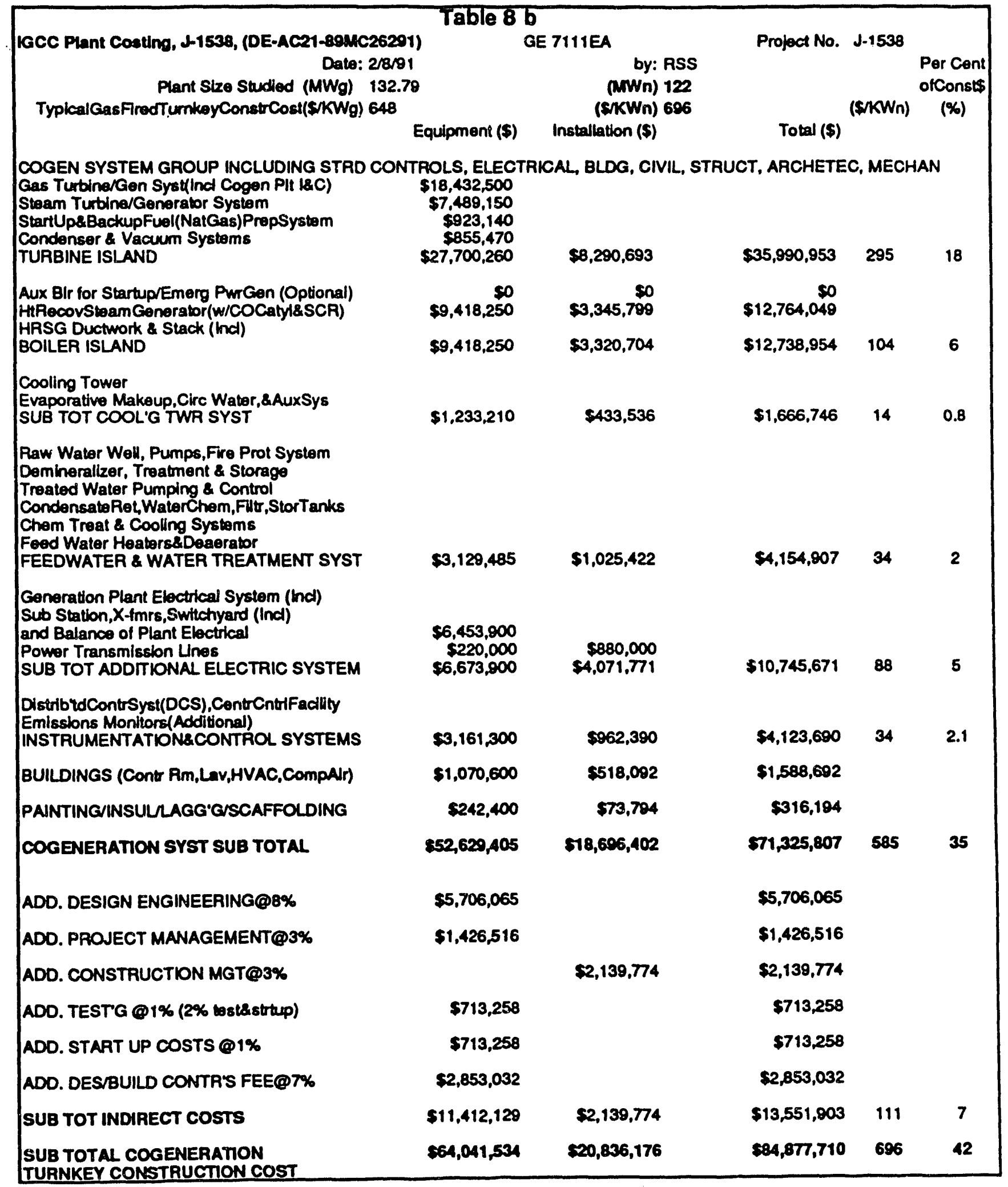




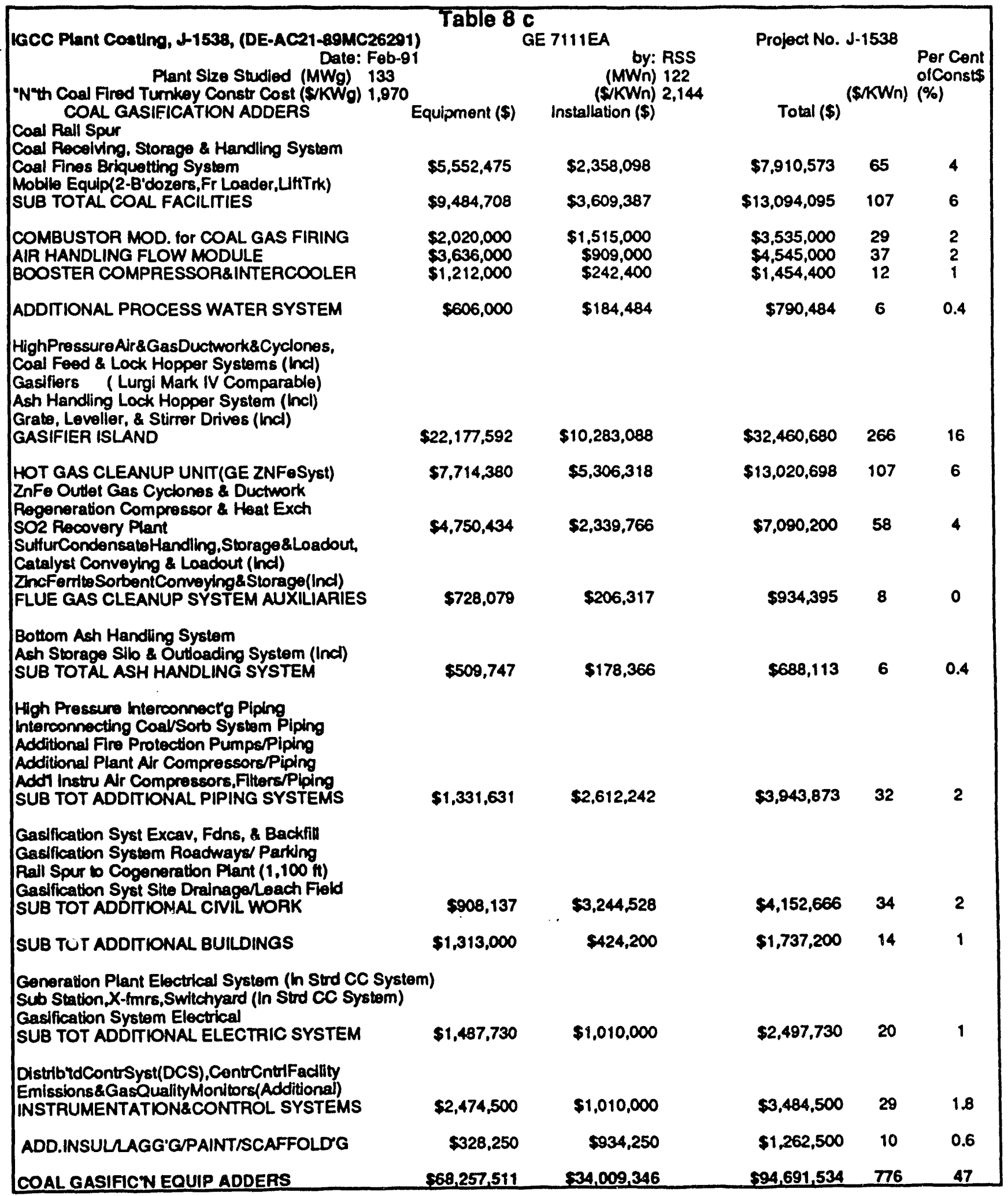




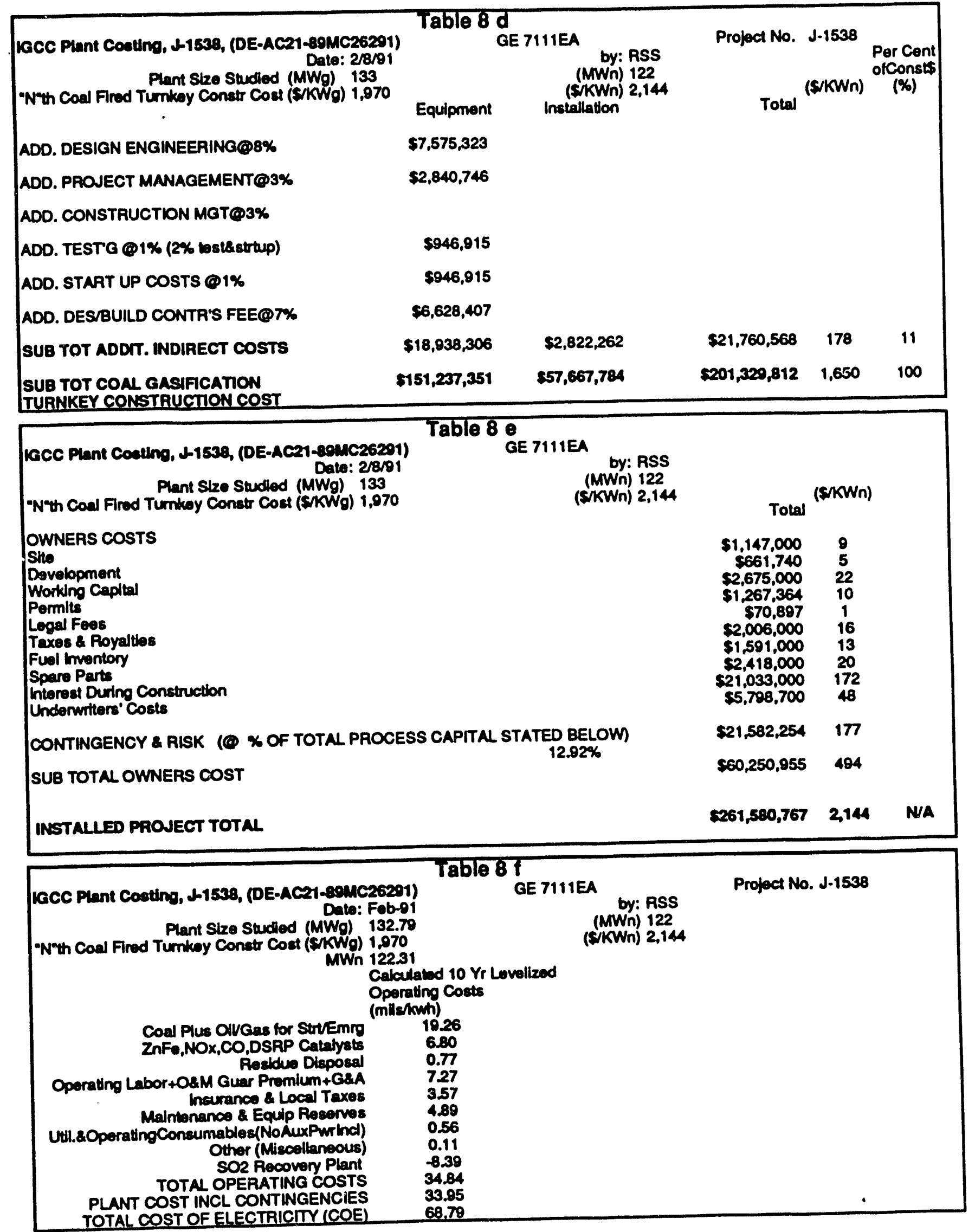




\subsubsection{Cost Sensitivity}

There appears to be a reasonable chance of making this 120 MWe capacity plant economical (Figure 11). The plant cost estimate sensitivity analysis for the $N^{\prime}$ th plant revealed costs of electricity (COE) from approximately $5.5 \mathrm{c} / \mathrm{kWh}$ to $7.5 \notin / \mathrm{kWh}$. Clearly, this result is economical in many geographical parts of the US almost irrespective of the value of the process steam which, at $5 \%$ thermal, represents only an incidental source of income.

\subsection{3. $200 \mathrm{MW}$ Size CGIA Concept}

Since it is anticipated that the $200 \mathrm{MWe}$ capacity could also be a "building block" modular capacity from which both the cogen/IPP and utility industries can produce CGIA standardized plants, this capacity was studied for both considerations.

\subsubsection{Cogeneration \& IPP Applications}

The schematic shown in Figure 13 reflects a basic CGLA concept applied as a STAG unit to a cogeneration (Cogen) or independent power production (IPP) facility. It utilizes a GE 7191F combustion turbine with an unfired hert recovery steam generator (HRSG), and a steam turbine/generator. Its HRSG generated steam is utilized to generate power with $5 \%$ of its thermal output reserved for process thermal use to qualify under Federal Energy Regulatory Commission (FERC) rules.

To meet the year 2000 goal of $0.1 \mathrm{lb} / \mathrm{MBtu}$ NOx emissions, ammonia injection/selective catalytic reduction (SCR) is deemed necessary.

Since CGLA employs a zinc ferrite ( $\mathrm{ZnFe}$ ) hot gas cleanup unit (HGCU), the $\mathrm{SO} 2$ emission limit goal of $0.1 \mathrm{lb} / \mathrm{MBtu}$ can be met with $99.5 \%$ desulfurization which is consistent with removal efficiencies of current HGCU designs. By the year 2000 , such impediments as sulfur bearing tars, and sulfur regeneration/recovery efficiency losses are judged to have been overcome by improved gasifier designs and HGC'J's. 


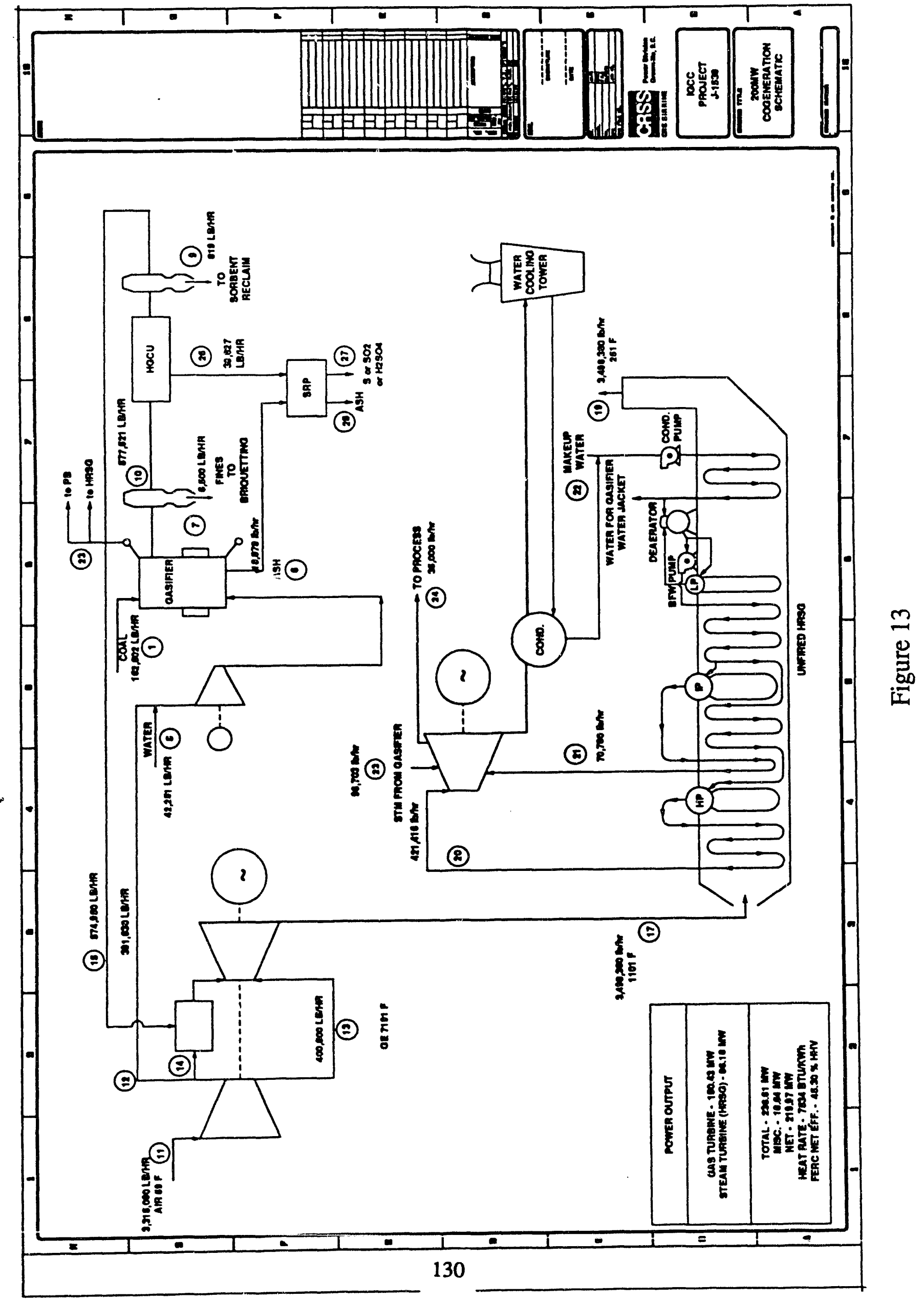


The nominal $200 \mathrm{MWe}$ plant generates a net output to the grid of 223-227 MWe. A plant cost estimate sensitivity analysis for the N'th plant revealed costs of electricity (COE) (Figure 14) from approximately $4 \pi / \mathrm{kWh}$ to $6 \notin / \mathrm{kWh}$. This result would be acceptable for applications in most areas of the country.

Its initial facility total costs are estimated at \$410-million (Table 9a). Applying $N^{\prime}$ th plant reduction factors [7] which lowered its anticipated costs to $\$ 251$-million reduces its costs sufficiently for very serious consideration.

A detailed cost analysis appears in Tables $9 b-9 f$. As in the previous case, the costs were initially estimated for a conventional natural gas fired combined cycle facility. The added costs of coal gasification were then added to the cogen plant costs. Sources of capital, terms, return rates expected, and ultimate costs of money were determined from costs typical of many small entrepreneurial cogen and IPP developers (Table 6). Owner's costs were also included in order to generate ultimate costs of electricity (COE).

\subsubsection{Utility Applications}

In an effort to determine its applicability to utility industry, the same cycle was reworked (Figure 15) at the same higher pressures and temperatures (relative to the previous $50 \mathrm{MWe}$ case) which are in line with utility practice. In this case there was no process steam included, and all steam generated from the unfired HRSG was utilized to generate power.

The result, as expected, was only a slight increase in power output over the previous case. This was caused by the anticipation of only minimal thermal use (5\%) in the cogen/IPP case, and both cases are limited in the Rankine cycle conditions by the low thermal head of the unfired HRSG.

The general arrangement drawing for the 50MWe sized plant is sho wn on Figure 16. Appendices $D \&$ E provide details of the plant selected. It is representative of an industrial cogeneration application. 


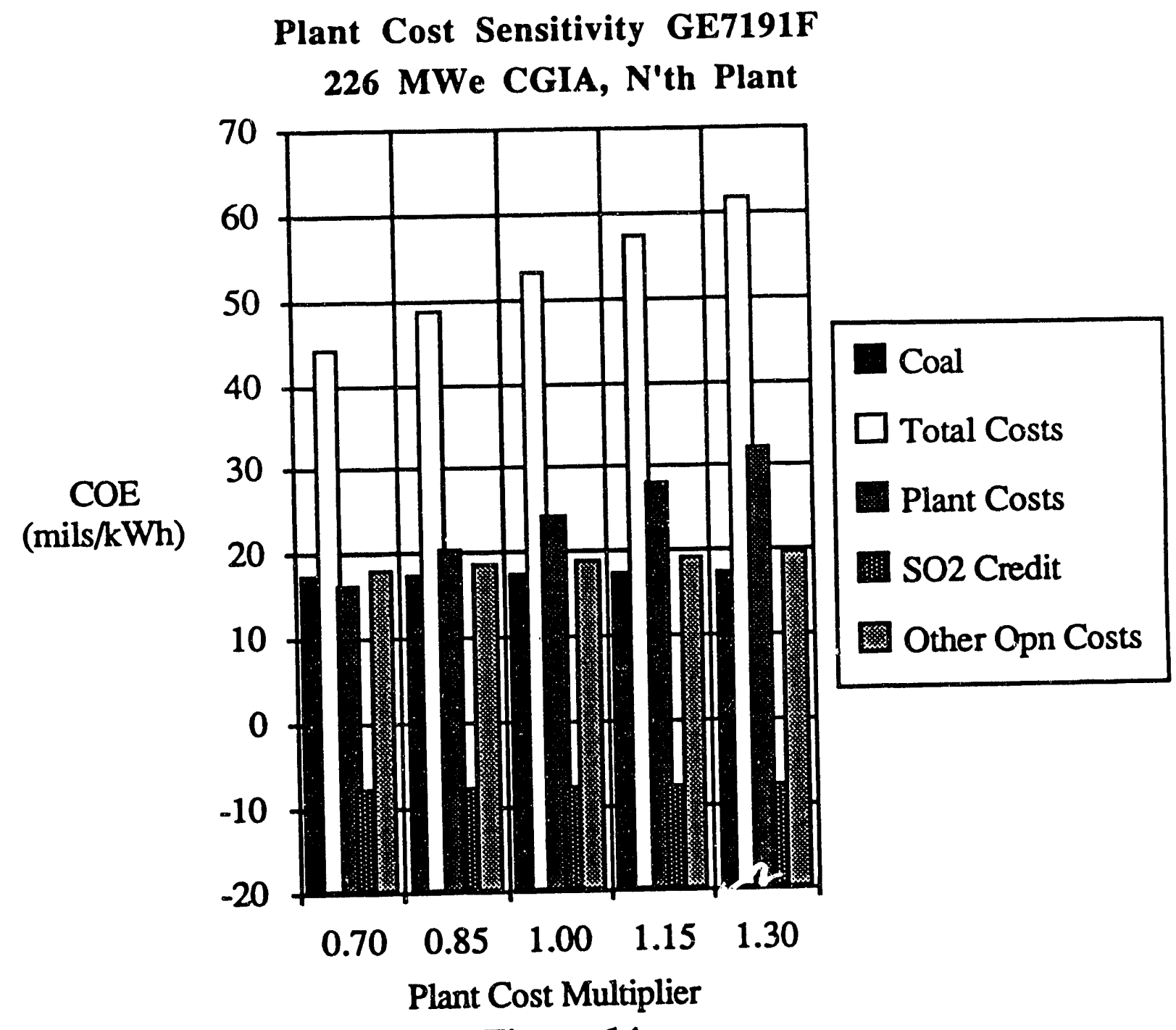

Figure 14 


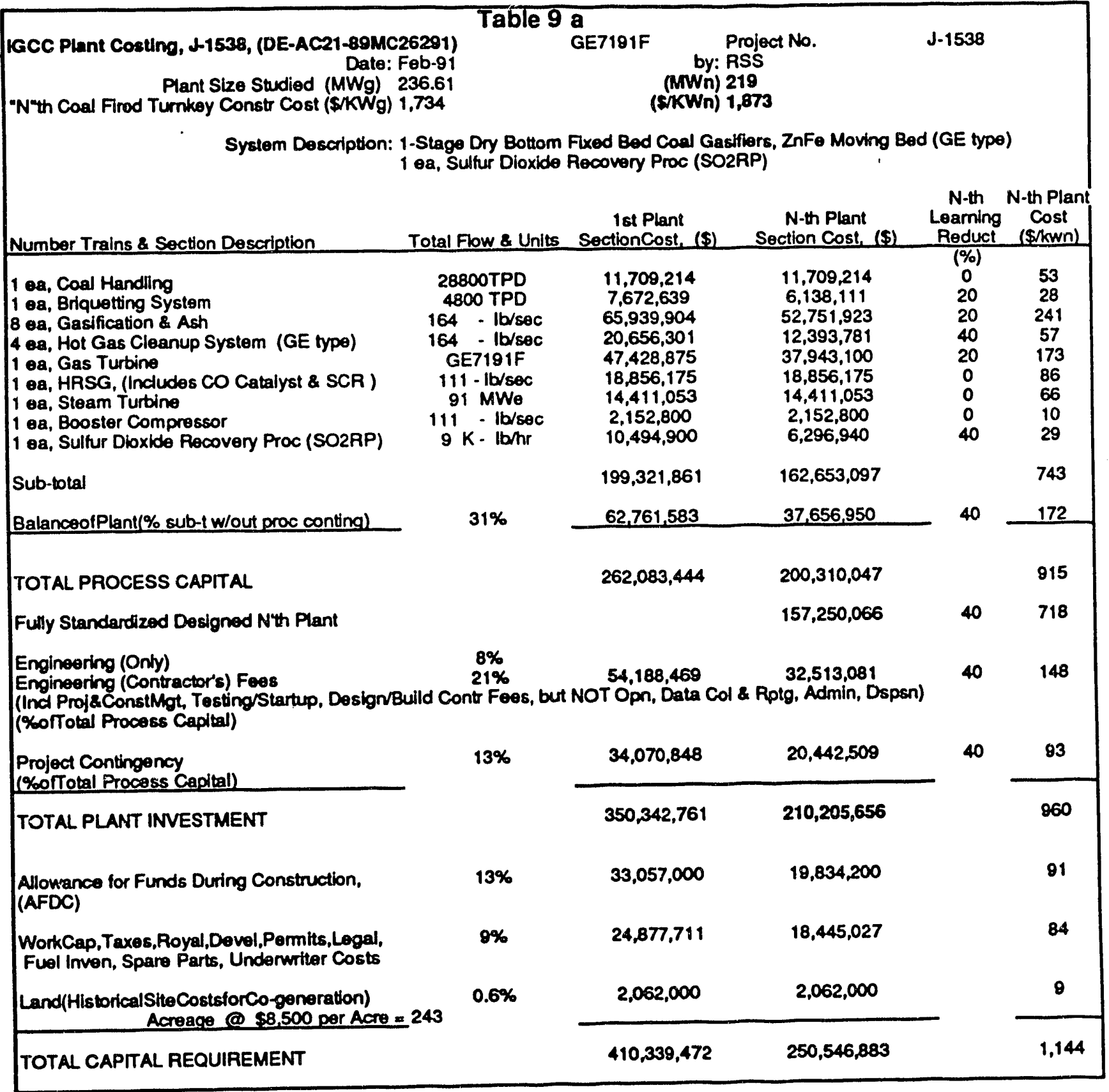




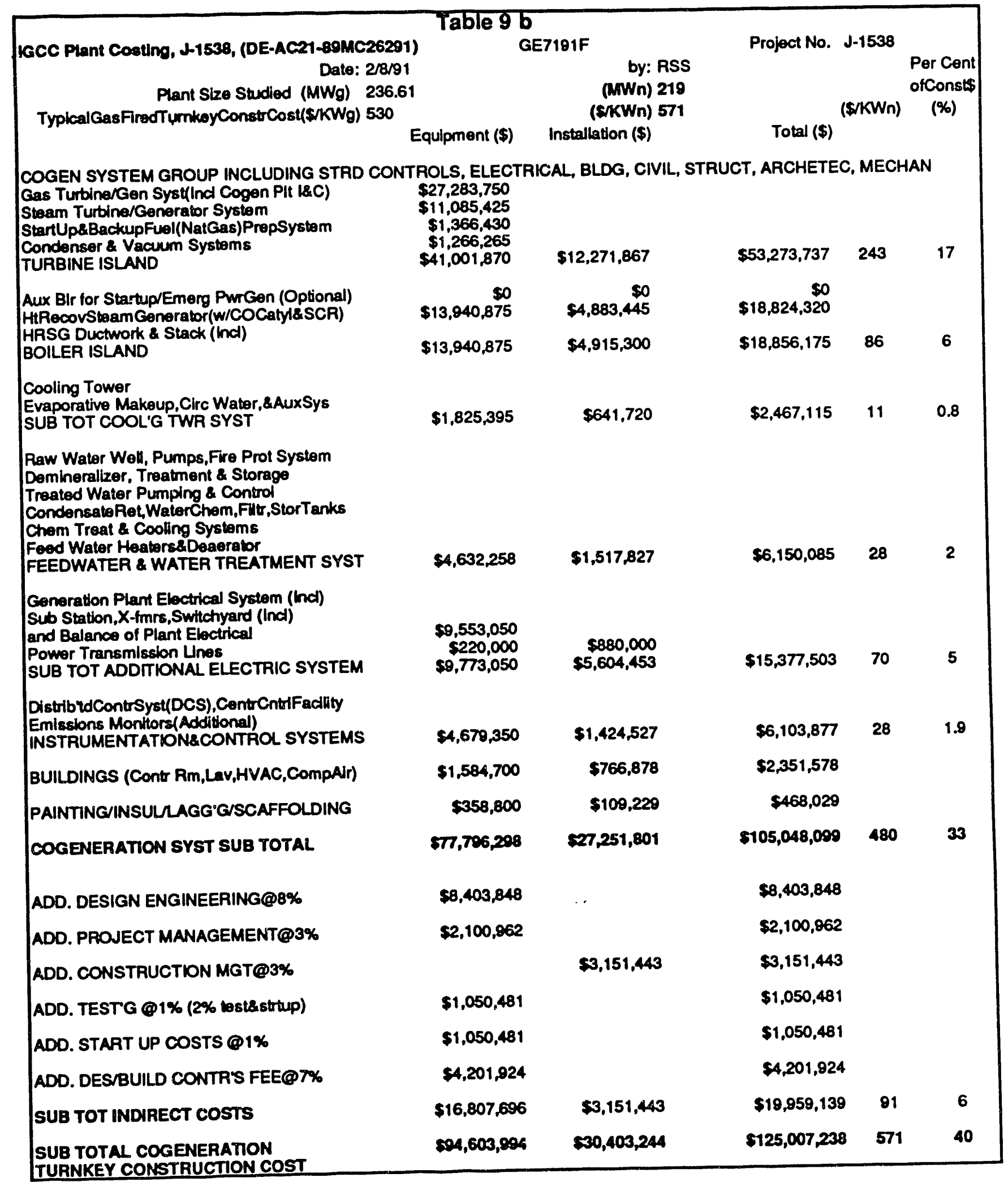




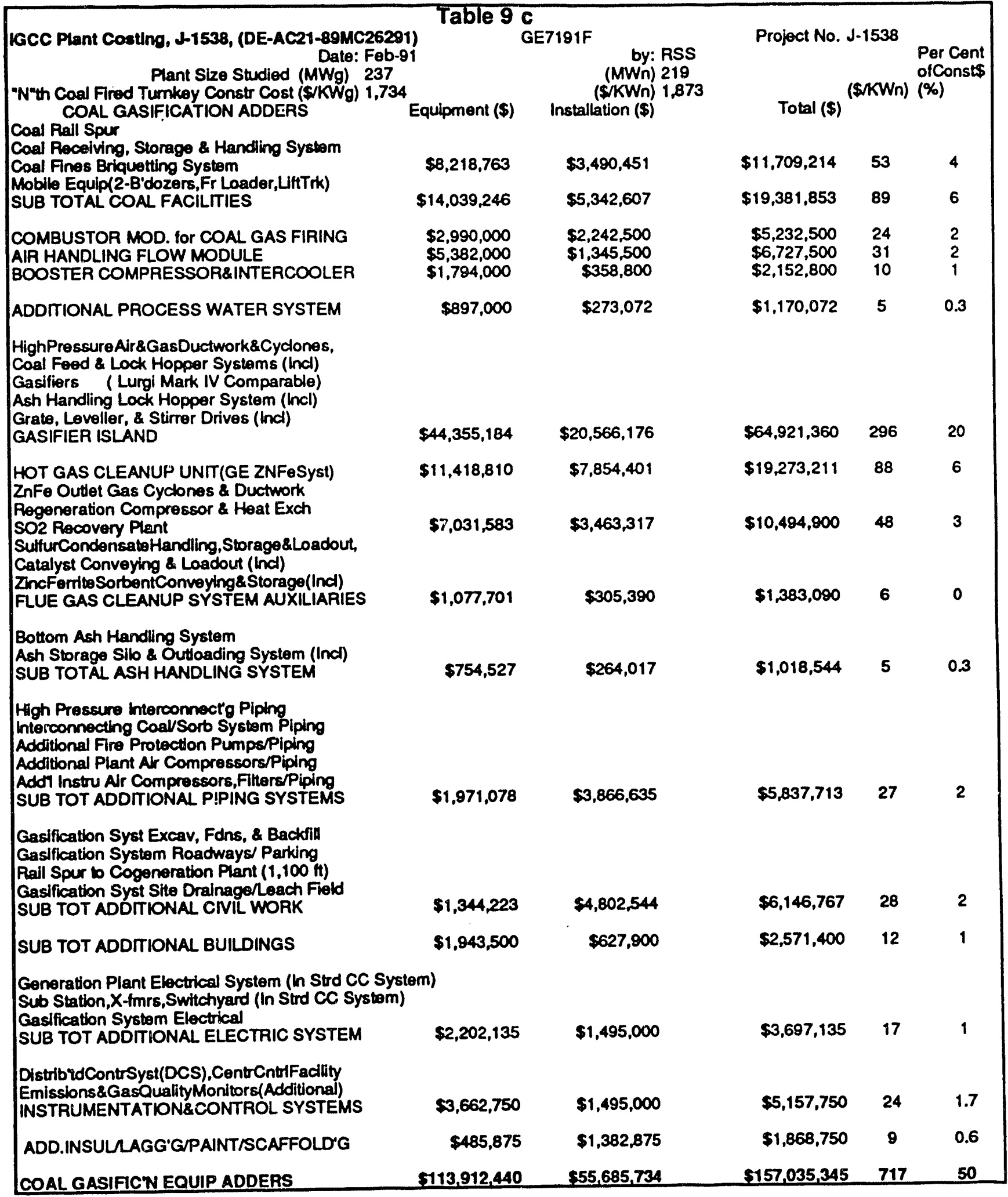




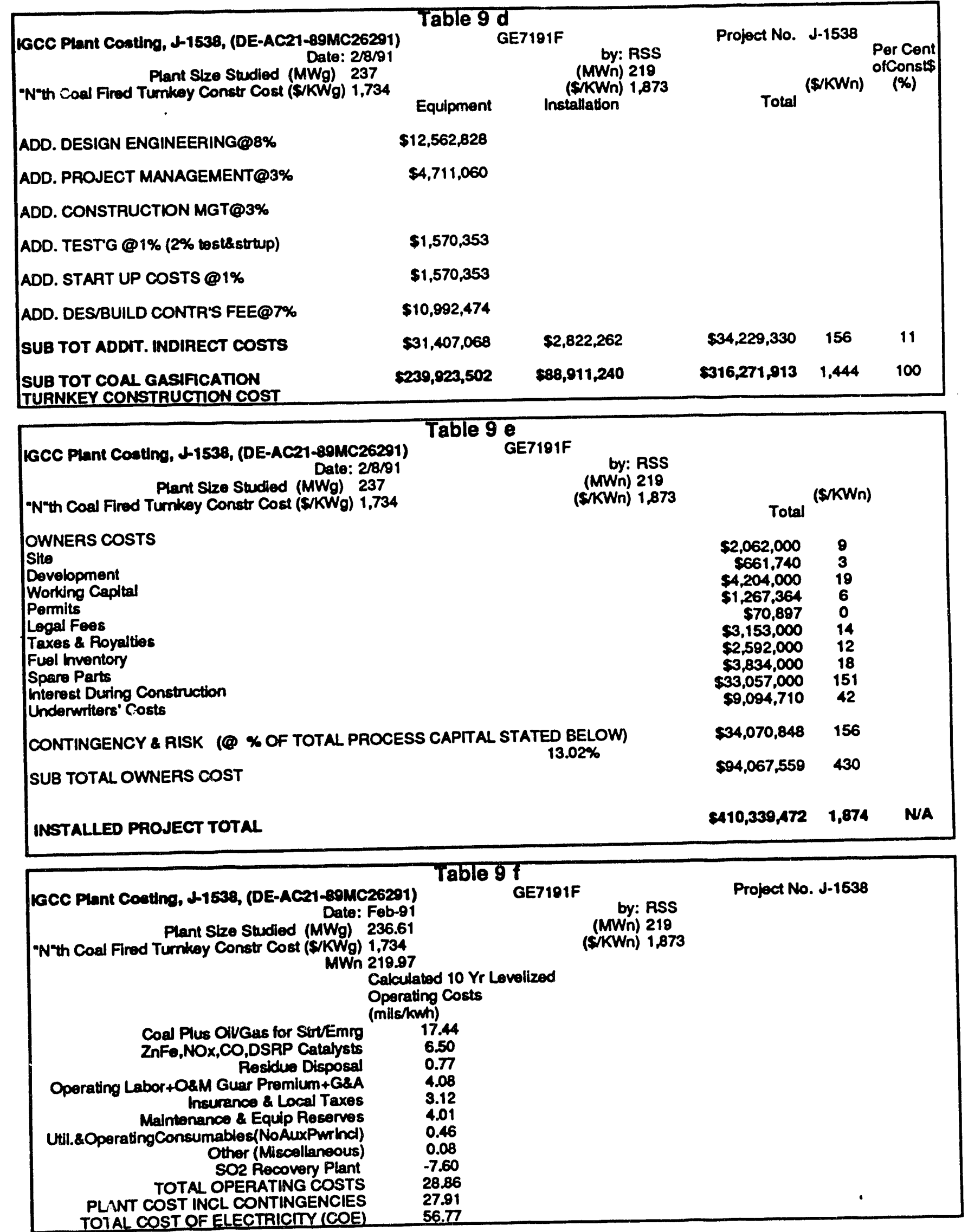




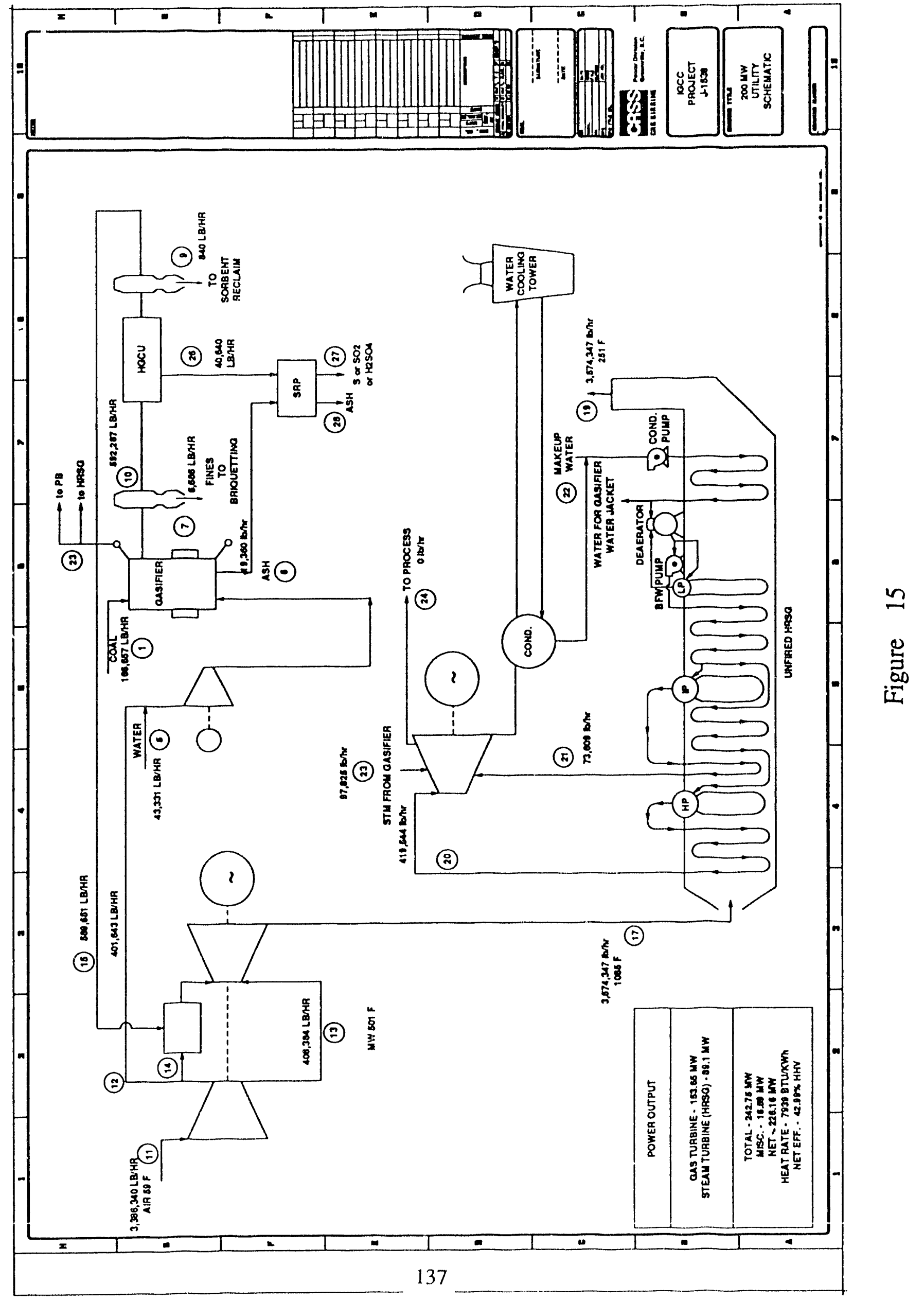




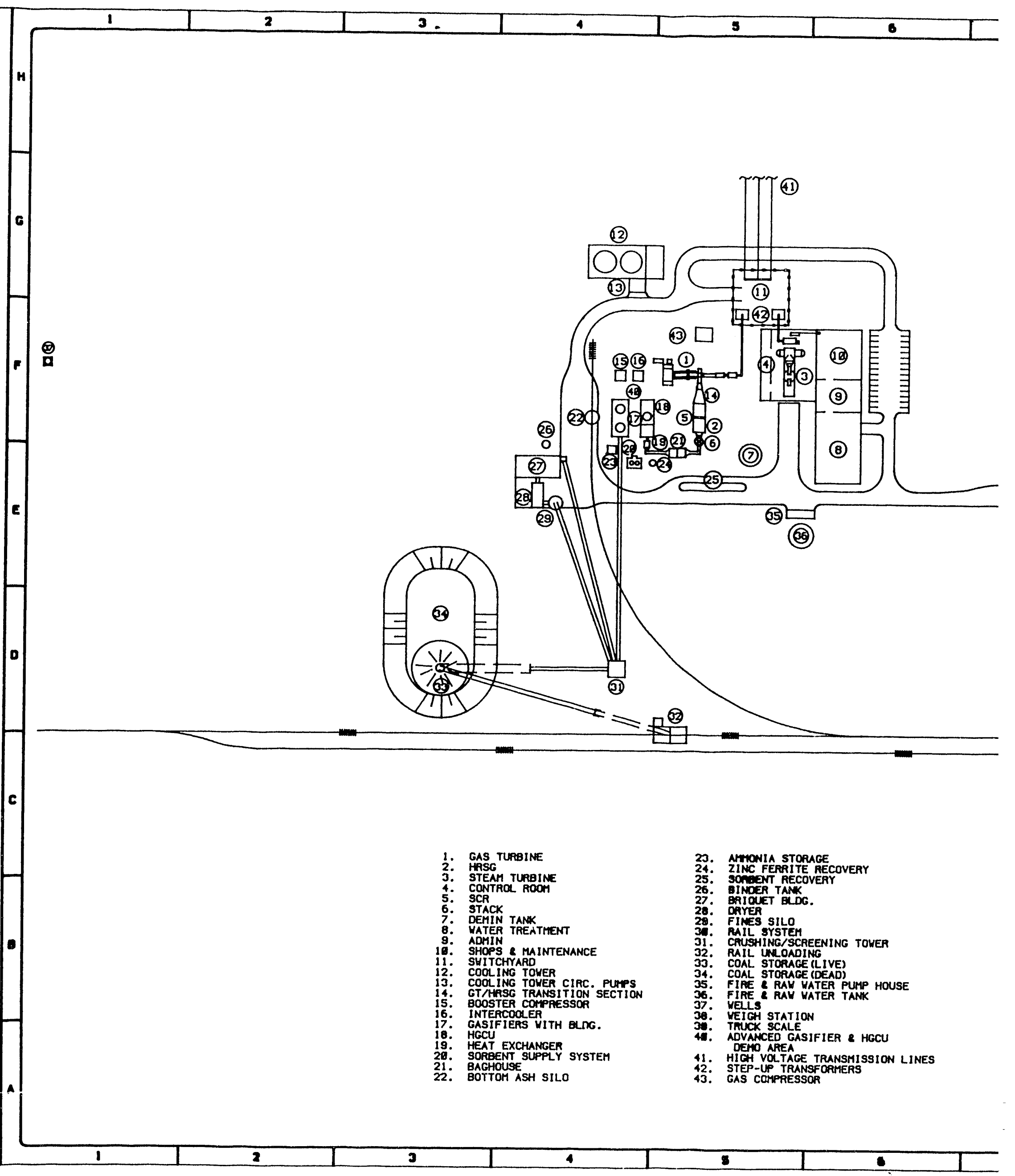




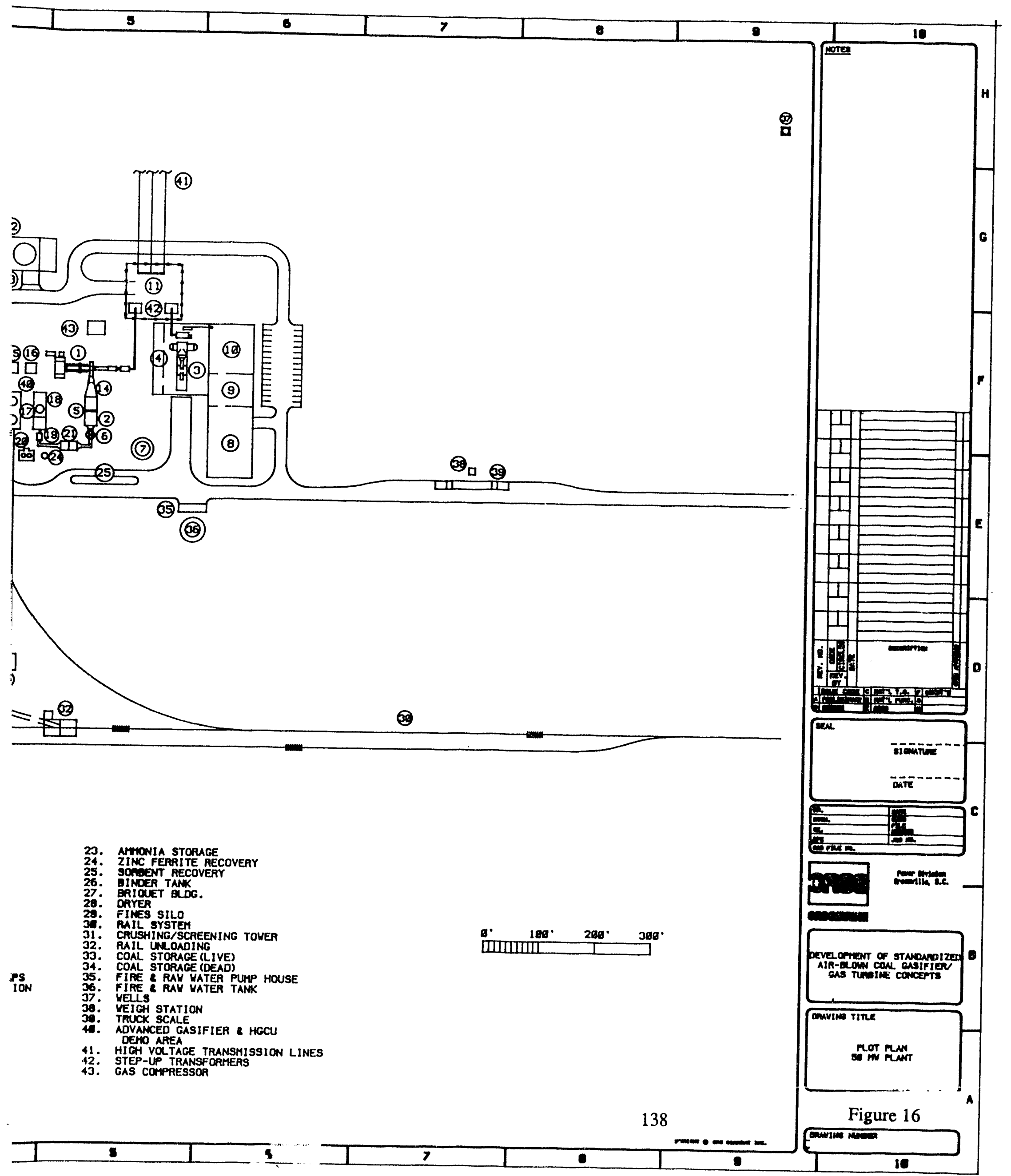


General arrangement drawing Figure 17 for the $100 \mathrm{MWe}$ sized facility provides for greater materials handling capabilities typical of an independent power producer (IPP) application.

Figure 18 shows the $200 \mathrm{MWe}$ sized plant. It provides for 100 car unit train capability. Such a plant is typical of utility practice, although, at 30 days supply, less fuel "dead storage" has been anticipated than utilities normally consider typical (90 days). This plant might be considered an IPP/Utility hybrid since it incorporates some features typical of both plant types. For example, a utility coal handling system is utilized, but cogeneration financial factors were used in its COE determination.

Standardized Gasifier/HGCU module front and side elevations are shown on Figures 19 and 20. A single module is sufficient for the $50 \mathrm{MW}$ plant size. The $100 \mathrm{MW}$ plant size requires two (2) such modules. The $200 \mathrm{MW}$ module includes four (4) modules, and the $500 \mathrm{MW}$ coal fired DOE reference plant needs six (6) modules for retrofit/repowering.

\subsubsection{Retrofit/Repowering of Coal Fired Utility Plant}

Three factors weigh heavily in the consideration of utilities as logical implementors of CGIA technology:

- Cogenerators and Independent Power Producers (IPP's) are not likely to to be interested in CGIA due to its high costs in the smaller size ranges of interest to them.

- Utilities are currently mandated [11] to reduce emissions from their largest coal fired power plants. They will evaluate all available technological solutions, and will find the added MWe output from CGIA an attractive alternative to IPP's for their load growth needs.

- Although the "N'th" CGIA plant is cost effective, the high cost of the.1st plant must be mitigated by such considerations as the utilization of existing coal plants which already have most of the equipment needed in place. Old 


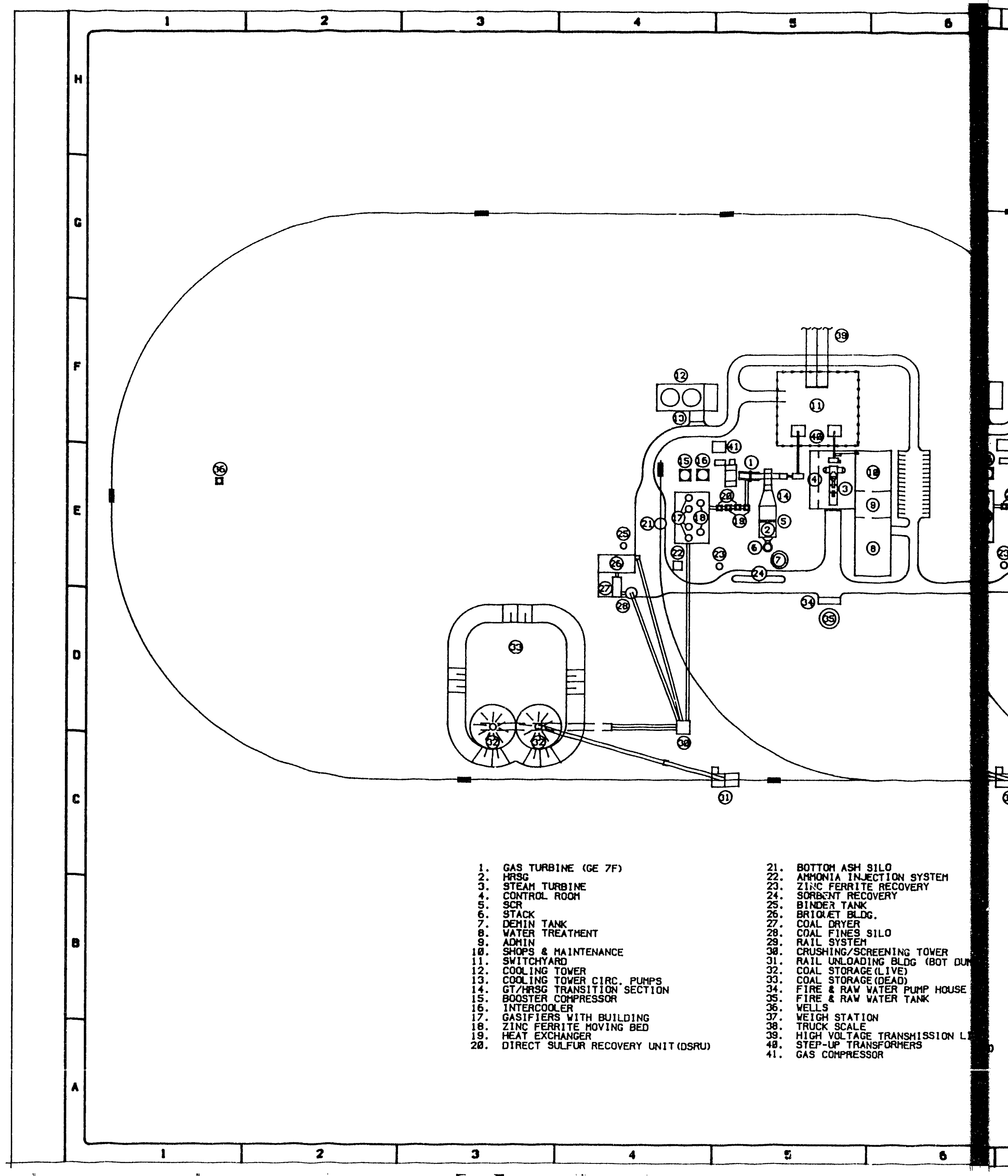




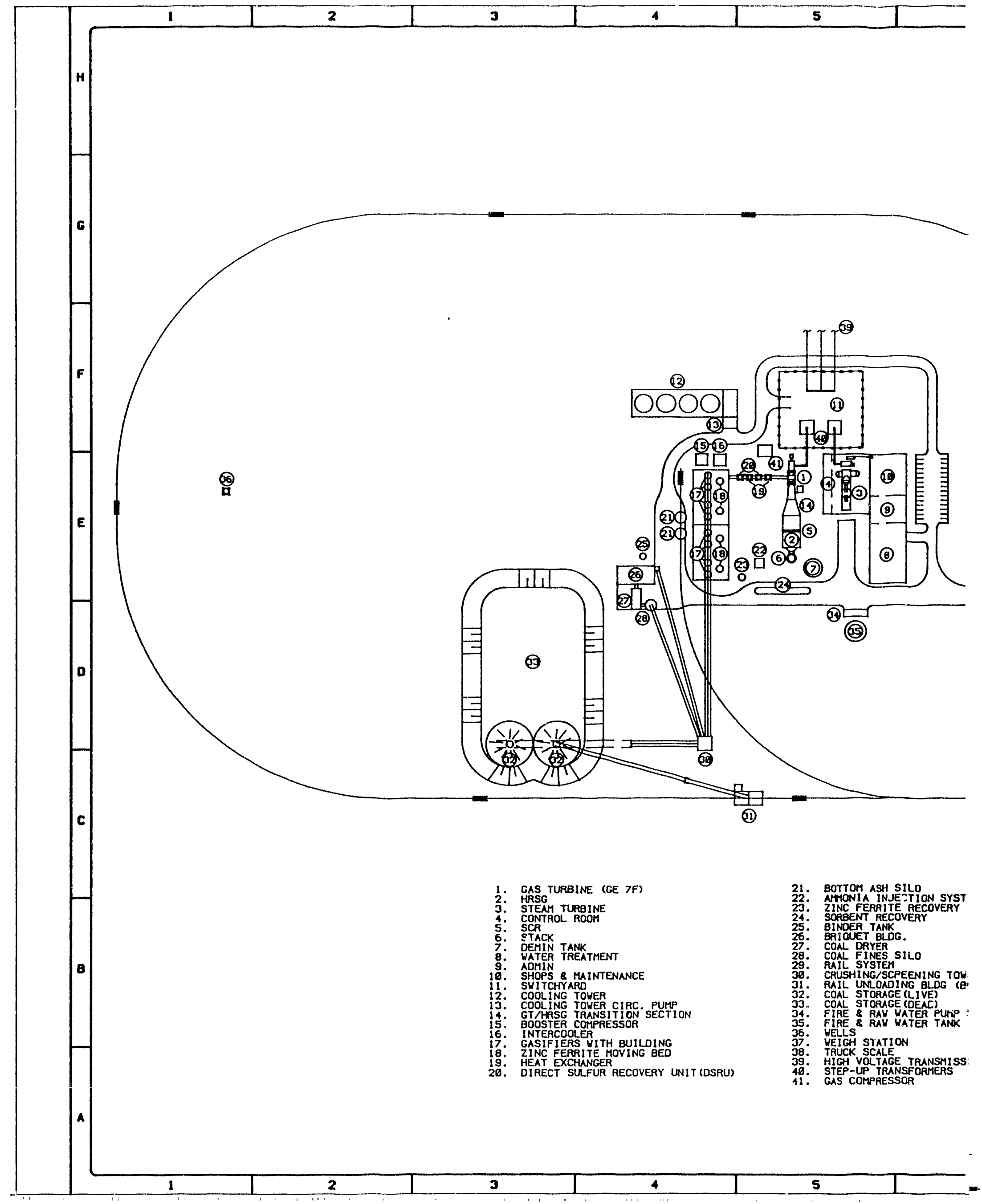


1

5

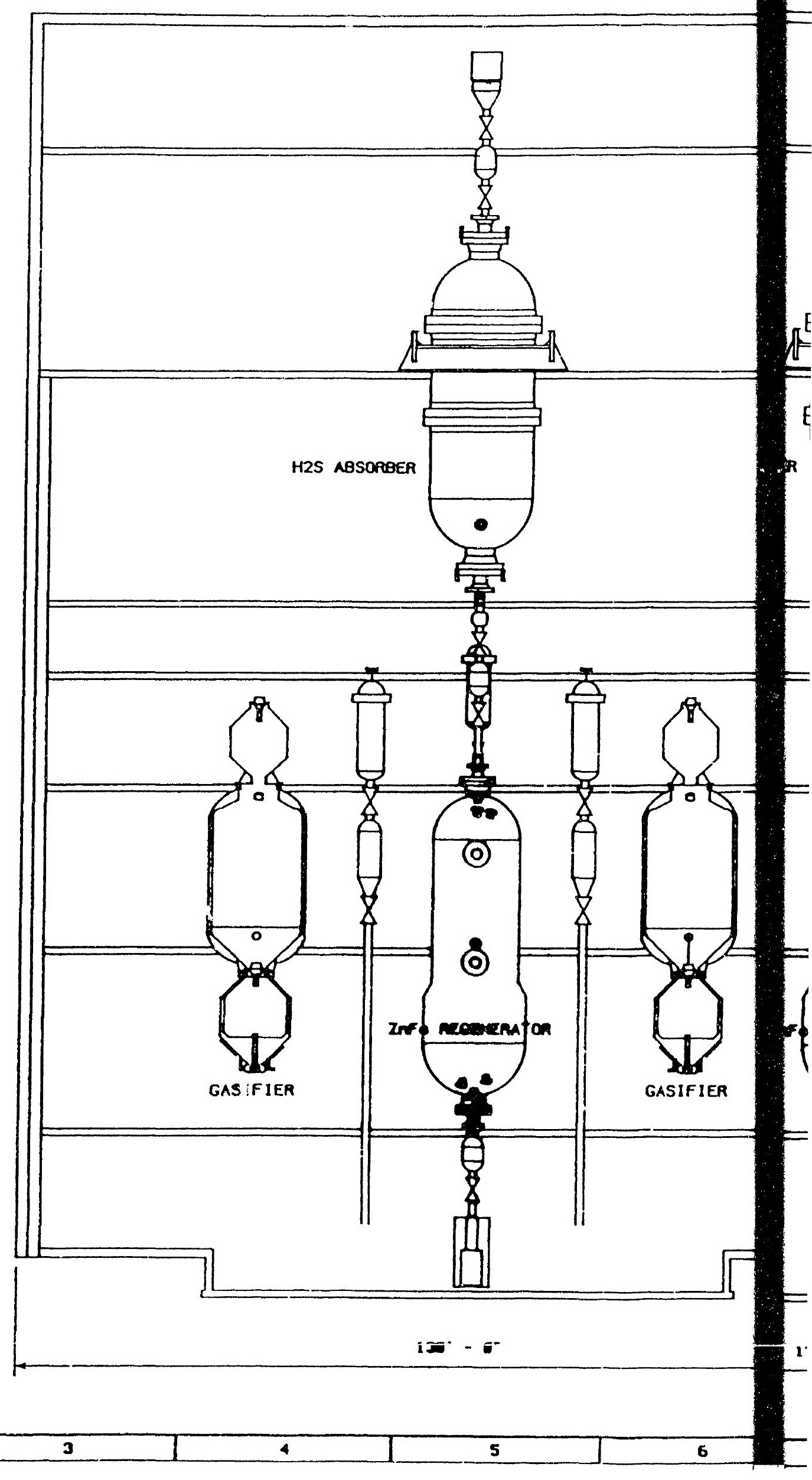




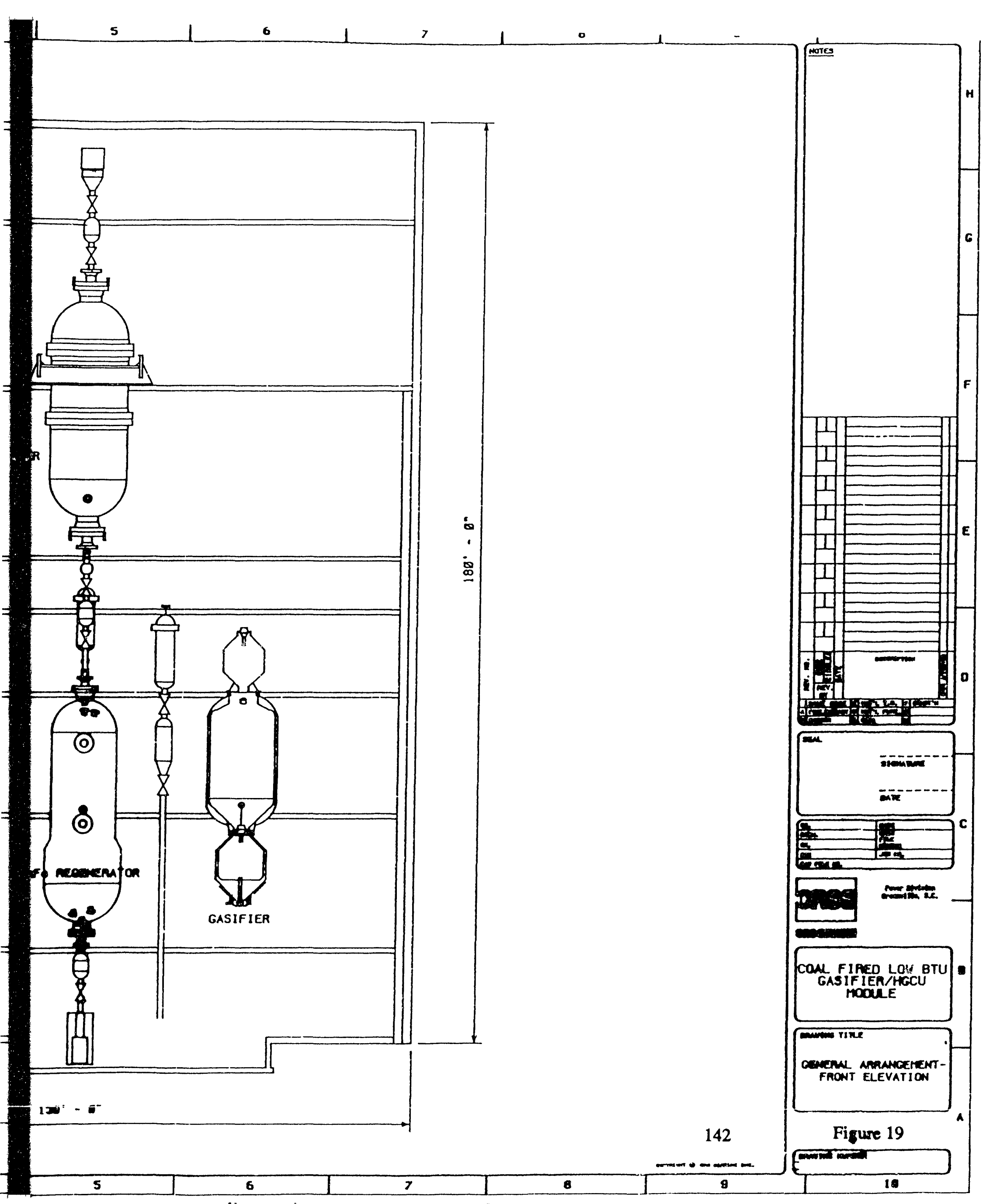





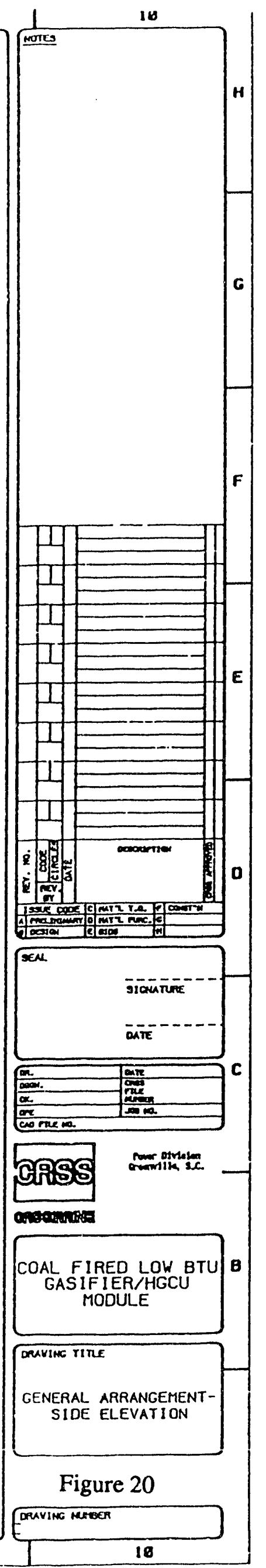


inefficient coal plants due to be retired represent excellent retrofit/repowering candidates, because CGIA improves their cycle efficiency by $20 \%$ or more.

To effectively evaluate a retrofit/repower strategy as applied to a coal fired utility power plant, a $150 \mathrm{MWe}$ class combustion turbine combined cycle plant was utilized to retrofit the DOE $500 \mathrm{MWe}$ coal fired reference plant using CGIA technology (Figure 21). This arrangement (Figure 22) simultaneously accomplished several important technical triumphs:

- It combined a very efficient Rankine cycle @ 2400 psig/1005/1005 reheat, with a very efficient Brayton cycle @ 2300 F combustion temperature resulting in a combined cycle efficiency well in excess of $40 \%$ net based on coal higher heating value [12].

- Consistent with this study's objective of achieving NOx emission values of less than $0.1 \mathrm{lb} / \mathrm{MBtu}$, it provided for the firing of low BTU coal gas in the existing coal boiler as a positive NOx control strategy using staged firing NOx reburn techniques [13].

- It reduced the oxygen content in the turbine exhaust gas to a minimum through firing supplemental low Btu gas in the existing boiler which served to maximize cycle efficiency by lowering the dry stack gas losses [14].

- Given an existing coal fired power plant with its inherent limitations, and then adding coal gasifiers and an external combustion turbine which consumes and converts a considerable per cent of the available energy, results are less than full load firing with the existing coal boiler. This should be looked upon as an inherent advantage since it alleviates the operating conditions of the existing (and sometimes overstressed at full load) coal boiler. 


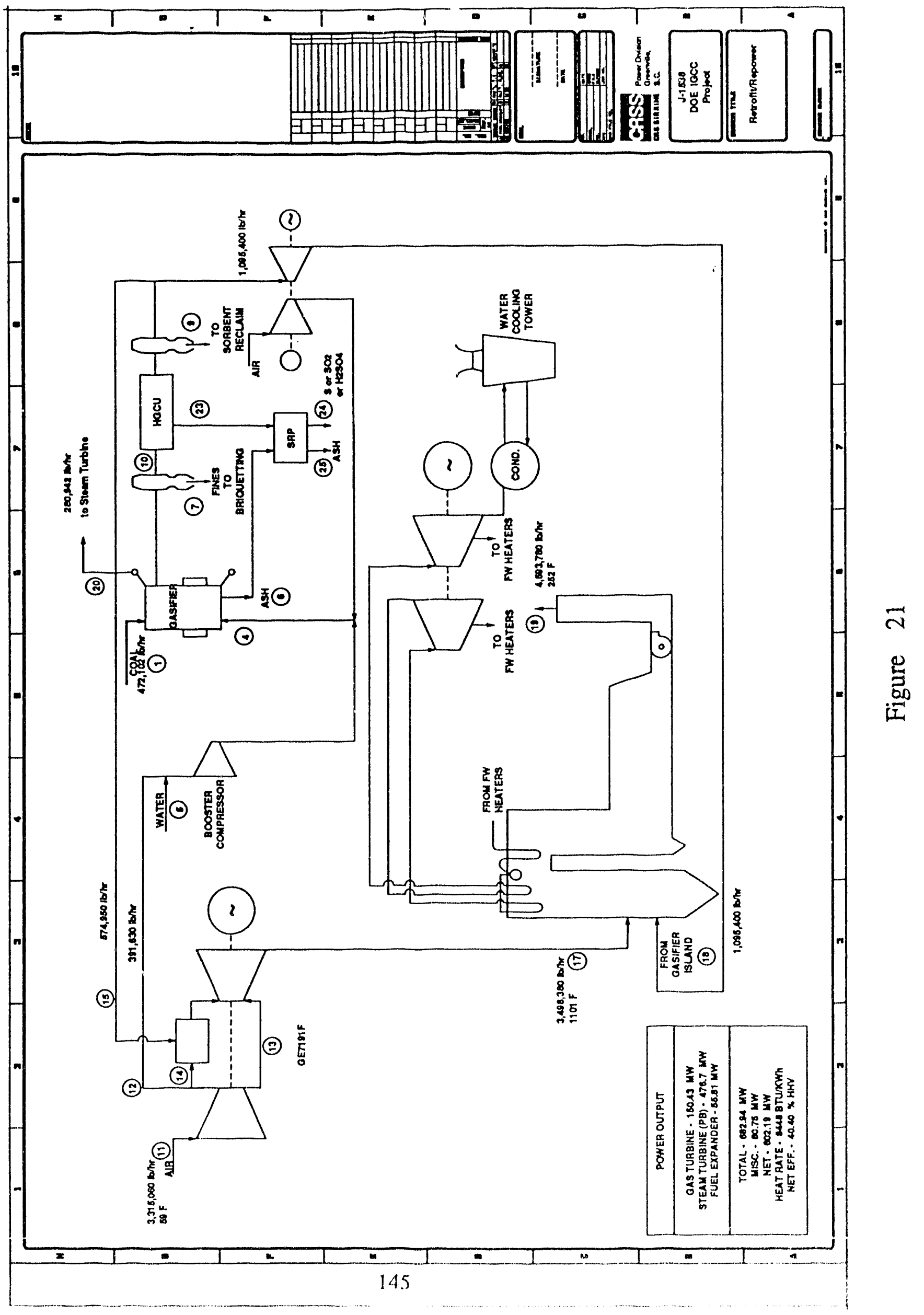




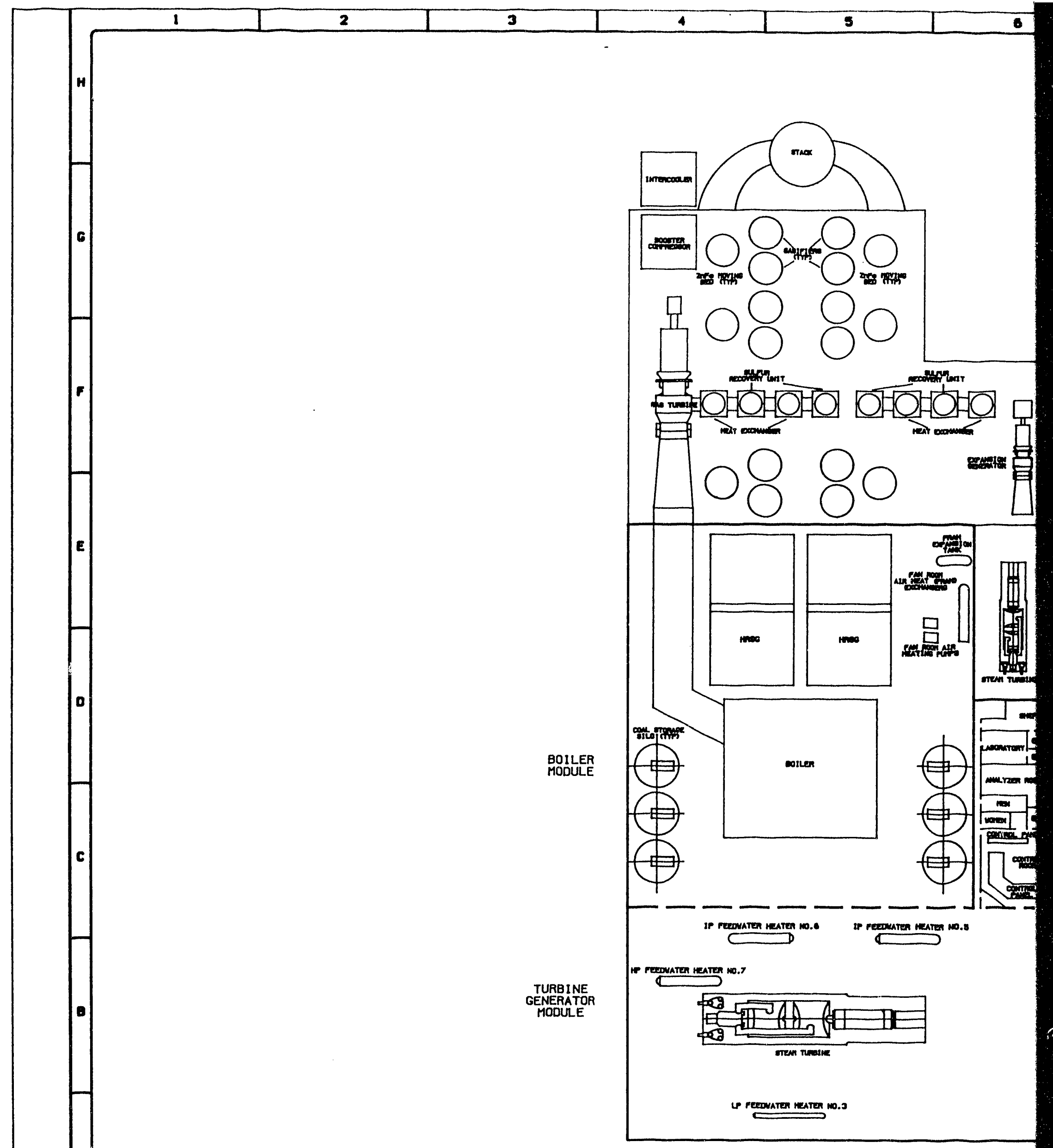




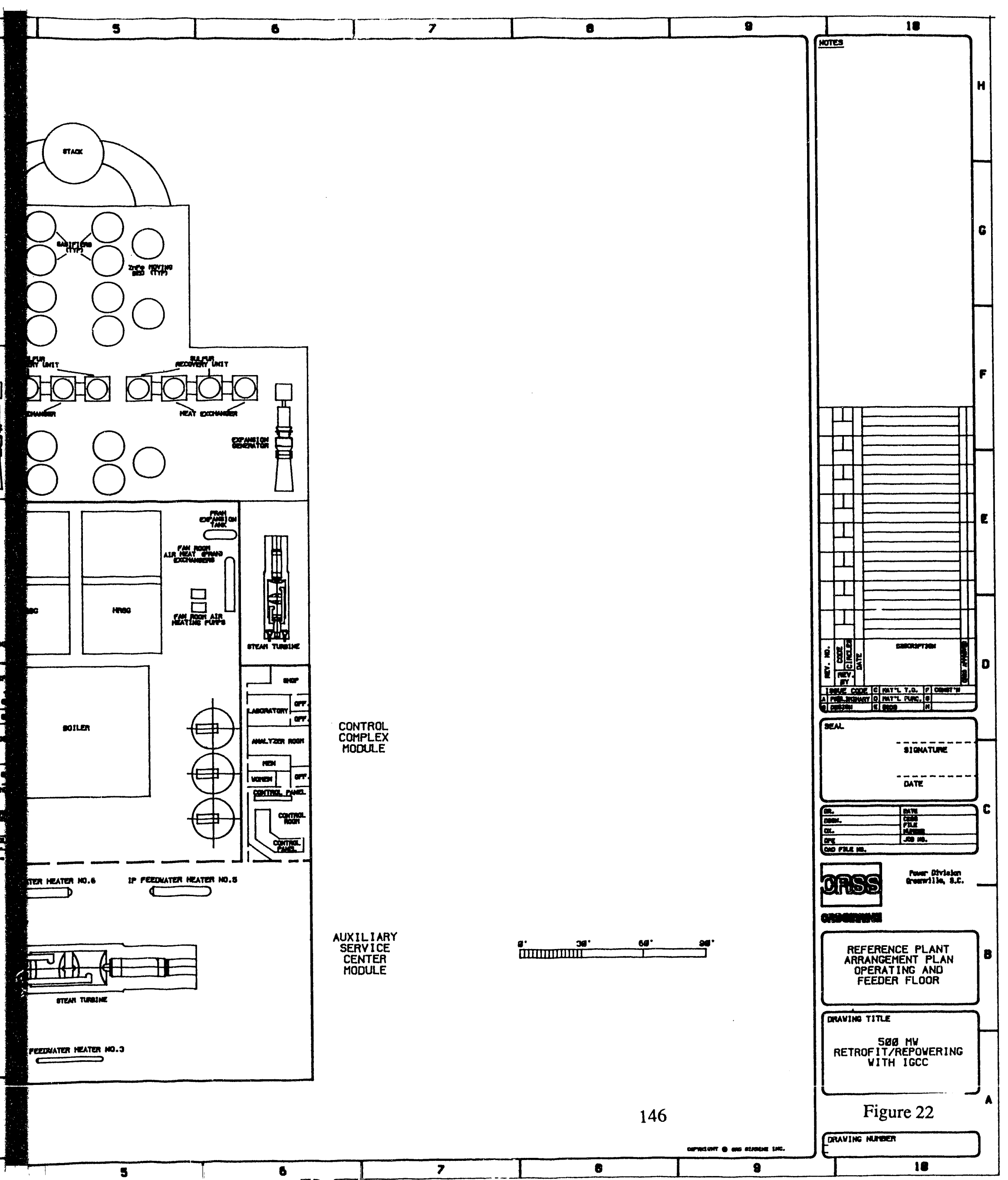


- The anticipated high furnace exit gas temperature (FEGT) when switching from pulverized coal to low Btu coal gas fuel is overcome by firing the existing coal boiler at a reduced capacity [15]. In this manner, any existing boiler's FEGT can be matched such that boiler performance can be maintained at close to original design conditions. To recover from the impact of expected reduced furnace absorptivity, a conventional unfired heat recovery steam generator section replaces the original air heater (or furnace water wall platens may be added).

- Since turbine exhaust gas provides considerable sensible heat to the low Btu gas fired converted coal boiler in addition to slightly more than the necessary oxygen for combustion in the converted coal boiler, the existing (presumably regenerative ) air heater is replaced with an unfired heat recovery steam generator (HRSG) to reduce the boiler exiting flue gas temperature to an acceptable stack exit temperature of 250 to $290 \mathrm{~F}$. A separate steam loop and small low pressure steam turbine/generator is added (as in the case of any combined cycle plant) due to the likelihood that the utility plant will have many feed water heaters in existence such that its feed water temperature will likely exceed $500 \mathrm{~F}$ precluding its use as a cooling medium for the boiler exit gas.

A comparison of the CGIA scheme (Table 10a - 10f) with retrofit wet limestone scrubbers [16] reveals that the "N'th" CGIA plant is less costly to install than the wet scrubber system on an evaluated basis. Such considerations as the comparative cost of the wet scrubber retrofit, a capavity credit for the additional MWe produced with the more efficient CGIA system, and an additional capacity credit for the additional parasitic power load attendant with the wet scrubber system all combined to favor the CGLA approach.

The operating costs (Table 10b) reveals that the itemized per kwhr cost of the wet scrubber is automatically increased by $3 \%$ since it uses up $3 \%$ of the plant's input energy in parasitic power draw. In addition, the CGIA scheme has a lower fuel cost per kwhr consistent with its greater efficiency than the original coal fired power plant. The wet scrubber also suffers from the cost of limestone sorbent, higher water consumption, and waste disposal. The CGIA is substantially credited with 
Rotro/Rpwr CGIA Plant Costing, (DE-AC21-89MC26291) Date: $1 / 28 / 91$

Original Plant Size (MWg) 536

Repowered Plant Size (MWg) 683 by:
(MWn) 510
(MWn) 602

GE7191F Prol. No.

RSS
$\mathrm{J}-1538$

Per Cent ofConst\$

(\$KWn)

System Description: 1-Stage Dry Bottom Fixed Bed Coal Gaslfiers (10-units), ZnFe (GE type), (5-units), SO2 Recovery Plant

RETROFTIREPOWERING OF EXISTING UTILITY COAL FIRED POWERPLANT

N-th Plant N-th N-th Plan Total Flow \& Units SectionCost. (\$) Soction Cost, (\$) Roduct (\$/kwn)

Number Trains \& Section Description

1 ea, Coal Handling

1 ea, Briquetting System

16 ea, Gasification \& Ash

8 ea, Hot Gas Cleanup System (GE typo)

1 ea, Gas Turbine

1 ea, HRSG, (Includes CO Catalyst \& SCR)

$\checkmark$ ea, Steam Tubine

8 ea, Booster \& Auxlliary Compressor

1 ea, Sulfur Dioxide Recovery Proc (SO2RP)

Demoltion of Existing Equipment

Sub-total

BalanceofPlant $(\%$ sub-1 w/out proc conting $)$

TOTAL PROCESS C,APITAL

Fully Standardized Designed Nth Plant

Engineering (Only)

Engineering (Contractor's) Foes

$3000 \mathrm{TPH}$
$131-\mathrm{Ib} / \mathrm{sec}$
$466-\mathrm{Ib} / \mathrm{sec}$
$\mathrm{GE} 7191 \mathrm{~F}$
$1274-\mathrm{lb} / \mathrm{sec}$
$316-\mathrm{lb} / \mathrm{sec}$
$1,382 \mathrm{~K}-\mathrm{b} / \mathrm{hr}$

0
0
86,007

0

$86,007,497$

$39,629,965$

$58,832,000$

0

$14,731,200$

$23,938,200$

$14,105,439$

$258,798,675$

$15 \%$

$297,991,317$

$9 \%$

$22 \%$

$65,143,948$
$21,554,374$

0

68, 0505,998

$23,777,979$

$47,065,600$

$21,554,374$

0

$14,731,200$

$14,362,920$

$14,105,439$

$204,403,510$

$23,515,585$

$227,919,095$

$178,794,790$

$39,086,369$

g. Admin, Dspsn)

(Incl Proj\&ConstMgt, Testing
(\%orTotal Process Capltal)

Project Contingency

(\%oftotal Process Capital)

TOTAL PLANT INVESTMENT

Allowance for Funds During Construction,

(AFDC)

WorkCap,Taxes,Royal,Devel,Permits,Legal,

Fuel Inven, Spare Parts, Underwriter Costs

Land(HistoricalSiteCostsforCo-generation)

Acreage@ $\$ 8,500$ per Acre $=0$

$13 \%$

$38,738,871$

$23,243,323$

$401,874,136$

$241,124,482$

$13 \%$

$37,920,000$

$37,920,000$

$8 \%$

$24,963,260$

$24,963,260$

$0.0 \%$

0

$\mathbf{0}$

$464,757,396$

$304,007,742$

$173,400,000$

$173,400,000$

LESS CAPITAL COST OF SCRUBBERS WROW NOX BURNERS \& SNCR

(Source: J.A. Wertane, W. DePriest, \& D.G. Sloat, Oct., 1990)

LESS CREDIT FOR ADDITIONAL CAPACITY of

107 MWe (Increased Capacity + Scrubber Parasitic Power) $-40,592,258$

(\%)

0

20

20

40

20

0

0

0

40

0

0 135

47

92

42

0

29

28

401

40

46

447

40

351

40

77

40

46

74

49

0

596

340

1,600

$-80$ 


\section{Table 10b}

Rotro/Rpwr CGIA Plant Costing, (DE-AC21-89MC26291)

Date: 1/28/91

Original Plant Size (MWg) $\mathbf{5 3 6}$

Repowered Plant Size (MWg) 683

\author{
CGIA
}

CGIA
Calculated 10

Cakculated $10 \mathrm{Yr}$ Levil

Lev'l Opritg Costs Operating Costs

(mils/kwh)

Coal Plus OllGas for Strt/Emrg ZnFe,NOx,CO,SRP Catalysts Residue Disposal Operating Labor+G\&A Insurance \& Taxes

Maintenance \& Equip Reserves Util.\&OperatingConsumables(NoAuxPwrincl) Other (Miscellaneous)

Llquid Sulfur Dioxide Recovery Credit

TOTAL OPERATING COSTS

PLANT COST INCL CONTINGENCIES TOTAL COST OF ELECTRICITY (COE)
602

18.65

4.42

0.77

2.04

3.48

3.15

0.48

0.07

$-8.13$

24.93

30.77

55.7 by:

(MWn) 510

(MWn) 602

Scrubbers

GE7191F Pro). No. RSS

(\$N/Wn) (mils/kwh)

495

22.90

4.69

2.82

2.10

4.07

3.68

0.51

0.07

0.00

40.84

17.55

58.39
@3\% Plant input Scrubber Pwr delta Effic \& Pwr Incl

L'stn,NOx,CO Cat

delta Pwr Incl

delta Pwr Incl

delta Pwr Incl

delta Pwr Incl

H2O Use@3GPM/MW hr 
Table 10c

Rotro/Rpwr CGIA Plant Costing, (DE-AC21-89MC26291)

Date: 1/28/91

Original Plant Size (MWg) 536

Repowered Plant Size (MWg) 683

Equipment (\$) Installation (\$) 602

by: RSS

(MWn) 510

Total (\$)
Pro]. No. J-1538

Per Cent

ofConst\$

(\%)

COGENERATION SYSTEM GROUP INCLUDING STRD CONTROLS, ELECTRICAL, BLDG, CIVIL, STRUCT, ARCHETEC, MECHAN Gas Turbine/Gen Syst(incl Blr Fuel Exp Tbn) $\$ 35,840,000$

Steam Turbine/Generator System

StanUp\&BackupFuel(NatGas)PrepSystem

Condenser \& Vacuum Systems

TURBINE ISLAND

$\$ 0$
$\$ 0$

50

$\$ 35,840,000$

$\$ 10,226,333$

$\$ 46,066,333$

204

13

$\$ 10,800,000$

$\$ 0$
$\$ 3,287,827$

$\$ 14,087,80$

$\$ 16,524,000$

$\$ 5,030,374$

$\$ 21,554,374$

95

6

\$o

$\$ 0$

$\$ 0$

0

0.0

Evaporative Makeup, Circ Water,
SUB TOT COOLG TWR SYST

Raw Water Well, Pumps,Fire Prot System

Demineralizer, Treatment \& Storage

Treated Water Pumping \& Control

CondensateRet, WaterChem, Filtr,StorTanks

Chem Treat \& Cooling Systems

Feed Water Heaters\&Deaerator

FEEDWATER \& WATER TREATMENT SYST

so

$\$ 0$

$\$ 0$

0

0

Generation Plant Electrical System (Incl)

Sub Station,X-Imrs,Switchyard (Incl)

and Balance of Plant Electrical

$\$ 6,390,000$

Power Transmission Lines

SUB TOT ADDITIONAL ELECTRIC SYSTEM
$\$ 9,776,700$

DistribidContrSyst(DCS), ContrCntrfFacility

Emissions Monitors(Additional)

INSTRUMENTATION\&CONTROL SYSTEMS

BUILDINGS (Contr Rm,Lav,HVAC,CompAir)

PAINTING/INSULLAGG'G/SCAFFOLDING

COGENERATION SYST SUB TOTAL

DESIGN ENGINEERING @ $8 \%$ of syst cost

PROJECT MANAGEMENT @ $2 \%$ of syst cost

$\$ 4,788,900$

$\$ 1,457,877$

$\$ 6,246,777$

28

1.7

$\$ 0$

\$o

$\$ 0$

$\$ 367,200$

$\$ \$ 11,786$

$\$ 65,048,715$

$\$ 19,802,675$

$\$ 84,851,390$

375

23

$\$ 6,788,111$

$\$ 1,697,028$

CONSTRUCTION MANAGEMENT @3\% of syst cost

TESTING@1\%of syst cost(test\&strt-up sum typ2\%)

START UP COSTS @1\% of syst cost

$\$ 848,514$

$\$ 3,394,056$

DESIGNBUILD CONTRACTOR'S FEE @4\% of syst cos

SUB TOT INDIRECT COSTS

$\$ 13,576,223$

$\$ 78,624,938$

$\$ 22,348,217$
$\$ 2,545,542$

$\$ 6,788,111$

$\$ 1,697,028$

$\$ 2,545,542$

$\$ 2,545,542$

$\$ 848,514$

$\$ 848,514$

$\$ 3,394,056$

$\$ 16,121,765$
$\$ 100,973,155$

3

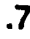

TURNKEY CONSTRUCTION COST 


\section{Table 10d}

Rotro/Rpwr CGIA Plant Costing, (DE-AC21-89MC26291)

Date: $1 / 28 / 91$

Original Plant Slzo (MWg) 536

Repowered Plant Size (MWg) 683

Coal Rail Spur COAL GASIFICATION ADDERS

(MWn) 602

by: RSS

(MWn) 510

Coal Receiving. Storage \& Handling System

Coal Fines Briquetting System

Moblle Equip(2-B'dozers,Fr Loader,LiftTrk)

SUB TOTAL COAL FACILITIES

COMBUSTOR MOD. for COAL GAS FIRING

'AIR HANDLING FLOW MODULE

BOOSTER COMPRESSOR\&INTERCOOLER

\section{ADDITIONAL PROCESS WATER SYSTEM}

HighPressureAir\&GasDuctwork\&Cyclones,

Coal Feed \& Lock Hopper Systems (Incl)

Gastilers (Lurgi Mark IV Comparable)

Ash Handling Lock Hopper System (Incl)

Grate, Leveller, \& Stirrer Drives (Incl)

GASIFIER ISLAND

HOT GAS CLEANUP UNIT(GE ZNFeSyst)

ZnFe Outlet Gas Cyclones \& Ductwork

Regeneration Compressor \& Heat Exch

SO2 Recovery Plant

SulfurCondensateHandling,Storage\&Loadout,

Catalyst Conveying \& Loadout (Incl)

ZincFeritteSorbentConveying\&Storage(Incl)

FLUE GAS CLEANUP SYSTEM AUXILIARIES

Bottom Ash Handling Systom

Ash Storage Sllo \& Outloading System (Incl)

SUB TOTAL ASH HANDLING SYSTEM

High Pressure Interconnect'g Plping Interconnecting Coal/Sorb System Piping Additional Fire Protection Pumps/Piping

Additiónal Plant Air Compressors/Piping

Add' Instru Air Compressors, Filters/Piping

SUB TOT ADDITIONAL PIPING SYSTEMS

Gasilication Syst Excav, Fdns, \& Backfill

Gastication System Roadways/ Parking

Rail Spur to Cogeneration Plant $(1,100 \mathrm{ft})$

Gasification Syst Site Drainage/Leach Fiold

SUB TOT ADDITIONAL CIVIL WORK

SUB TOT ADDITIONAL BUILDINGS

Generation Plant Electrical System (In Strd CC System)

- Sub Station,X-fmrs,Switchyard (In Strd CC System)

Gasification System Eloctrical

SUB TOT ADDITIONAL ELECTRIC SYSTEM

DistribtdContrSyst(DCS),ContrCntrfFacility

Emissions\&GasQualityMonitors(Additional)

INSTRUMENTATION\&CONTROL SYSTEMS

ADD.INSULIAGG'G/PAINT/SCAFFOLD'G

COAL GASIFIC'N EQUIP ADDERS \$o

$\begin{array}{rrrcr}\$ 0 & \$ 0 & \$ 0 & 0 & 0 \\ \$ 0 & \$ 0 & \$ 0 & 0 & 0 \\ \$ 3,060,000 & \$ 2,295,000 & \$ 5,355,000 & 24 & 1 \\ \$ 5,508,000 & \$ 1,377,000 & \$ 6,885,000 & 30 & 2 \\ \$ 12,276,000 & \$ 2,455,200 & \$ 14,731,200 & 65 & 4 \\ \$ 0 & \$ 0 & \$ 0 & 0 & 0.0\end{array}$

$\$ 57,025,216$

$\$ 27,239,856$

$\$ 84,265,072 \quad 373$

23

$\$ 20,808,782$

$\$ 13,713,922$

$\$ 34,522,704$

153

10

$\$ 16,038,594$

$\$ 7,899,606$

$\$ 23,938,200 \quad 106$

7

$\$ 3,687,250$

$\$ 1,044,862$

$\$ 5,107,261$

23

1

$\$ 1,290,770$

$\$ 451,655$

$\$ 1,742,425$

8

0.5

$\$ 4,294,264$

$\$ 8,349,061$

$\$ 12,643,325$

56

3

$\$ 2,301,750$

$\$ 9,207,000$

$\$ 11,508,750$

51

3

$\$ 1,108,250$

$\$ 358,050$

$\$ 1,466,300$

6

0

$\$ 2,25 \%, 690$

$\$ 1,530,000$

$\$ 3,783,690$

17

1

$\$ 3,748,500$

$\$ 1,530,000$

$\$ 5,278,500$

23

1.4

$\$ 497,250$

$\$ 1,415,250$

$\$ 1,912,500$

8

0.5

\$ิ150,949,5

$\$ 78,866,462$

$\$ 213,138,32\}$

.0

0




\section{Table 10e}

Rotro/Apwr CGIA Plant Costing, (DE-AC21-89MC26291) Date: 1/28/91

Original Plant Slze (MWg) 536 Repowered Plant Size (MWg) 683

ADDITIONAL DESIGN ENGINEERING @ 8\%

ADDITIONAL PROJECT MANAGEMENT @ 3\%

ADDITIONAL CONSTRUCTION MANAGEM'ENT@ 3\%

ADDITIONAL TESTING @1\% (2\% test\&strtup)

ADDITIONAL START UP COSTS @1\%

ADD. DESIGNBUUILD CONTRACTOR'S FEE @7\%

SUB TOT ADDIT. INDIRECT COSTS

SUB TOT COAL GASIFICATION

TURNKEY CONSTRUCTION COST
Equipment

$\$ 17,051.194$

$\$ 6,394,198$

$\$ 6,394,198 \quad \$ 6,394,198$

$\$ 2,131,399$

$\$ 2.131,399$

$\$ 14,919,795$

$\$ 42,627,985$

$\$ 272,202,433$
$\$ 6,394,198$

$\$ 107,608,877$
$J-1538$

by:

(MWn) 510

(MWn) 602

Installarion

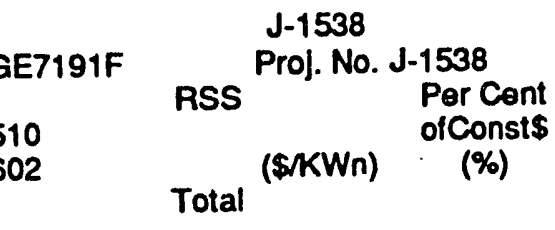

Table $10 f$

Retro/Rpwr CGIA Plant Costing, (DE-AC21-89MC26291)

Date: 1/28/91

Original Plant Size (MWg) 536

Repowered Plant Size (MWg) 683

OWNERS COSTS

Site

Development

Working Capital

Permits

Logal Feos

Taxes \& Royalties

Fuel Inventory

Spare Parts

Interest During Construction

Underwriters' Costs

CONTINGENCY \& RISK (@ \% OF TOTAL PROCESS CAPITAL STATED BELOW)

SUB TOTAL OWNERS COST

WSTALLED PROJECT TOTAL

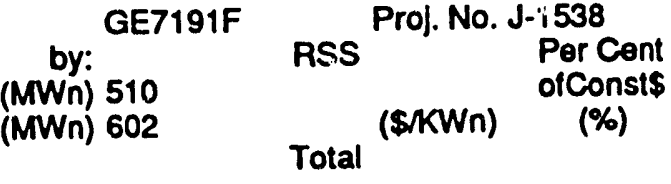

\begin{tabular}{|c|c|}
\hline $\begin{array}{r}\$ 0 \\
\$ 0 \\
\$ 4,822,000 \\
\$ 1,897,899 \\
\$ 102,101 \\
\$ 3,617,000 \\
\$ 0 \\
\$ 4,320,000 \\
\$ 37,920,000 \\
\$ 10,204,260\end{array}$ & $\begin{array}{c}0 \\
0 \\
21 \\
8 \\
0 \\
16 \\
0 \\
19 \\
168 \\
45\end{array}$ \\
\hline$\$ 38,738,871$ & 171 \\
\hline$\$ 101,622,131$ & 450 \\
\hline $464,757,396$ & 2,056 \\
\hline
\end{tabular}


its sulfuric acid byproduct. Secondary benefits of the CGLA system include a reduction in total water utilization of the original coal fired plant in contrast to a significant increase in water consumption for the wet scrubber scenario. In addition, the condenser/cooling tower capacity is sufficient to accommodate the flow from the additional low pressure steam turbine.

\subsubsection{Cost Sensitivity}

There appears to be an excellent chance of making this 575 MWe net capacity plant economical (Figure 23). The plant cost estimate sensitivity analysis for the N'th plant revealed costs of electricity (COE) from approximately $4 \notin / \mathrm{kWh}$ to $6 \notin / \mathrm{kWh}$. Clearly, this result is an economical alternative to wet scrubbers for retrofitting and repowering existing coal fired utility power plants.

Plant costs (Figure 24), and cost of electricity (COE) (Figure 25) reflect the lowest anticipated cost system. These figures reflect a PyGas (or equivalent METC scaled-up gasifier) installation. 


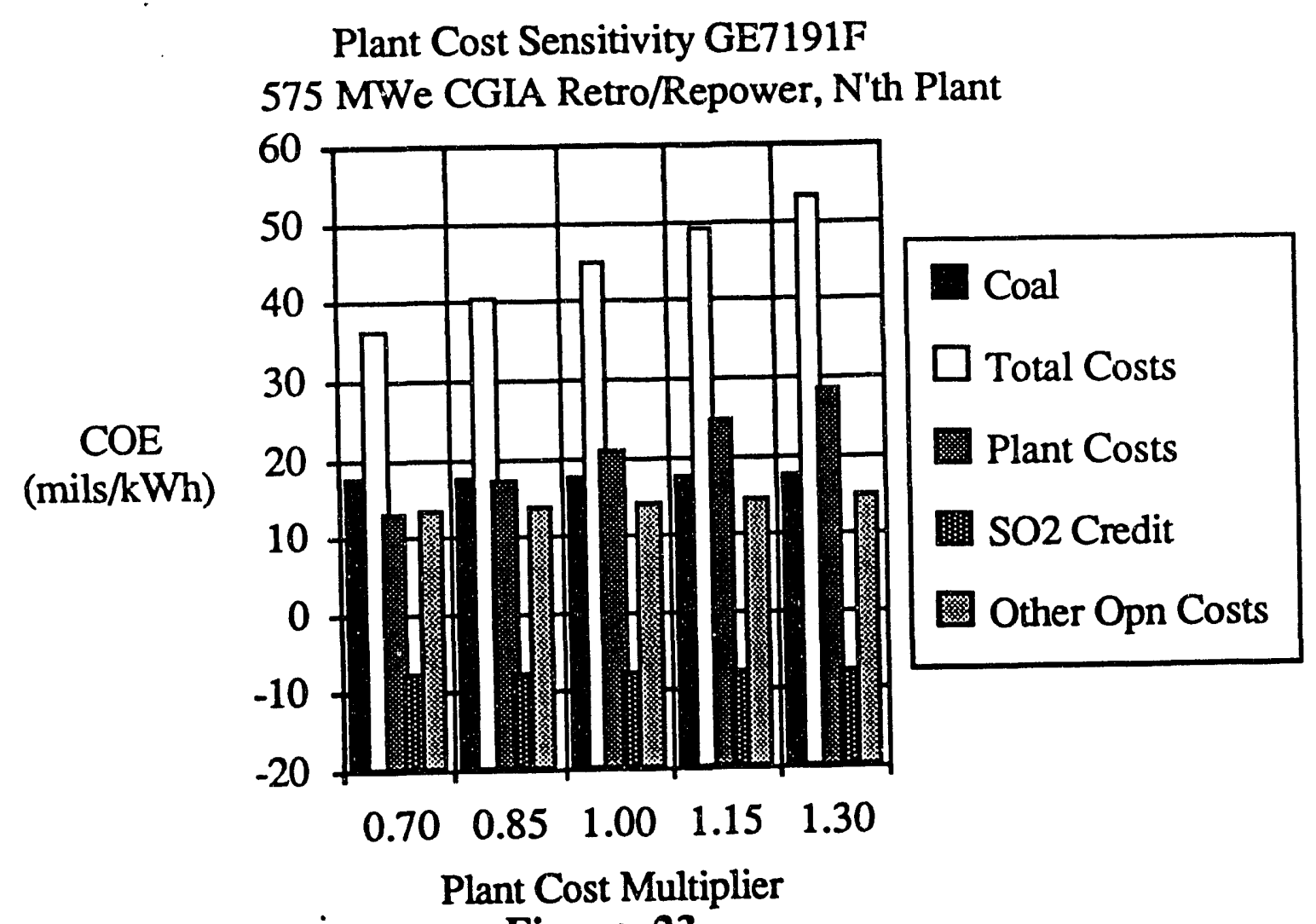

Figure 23 


\section{Air-Blown Fixed Bed IGCC Plant Costs}

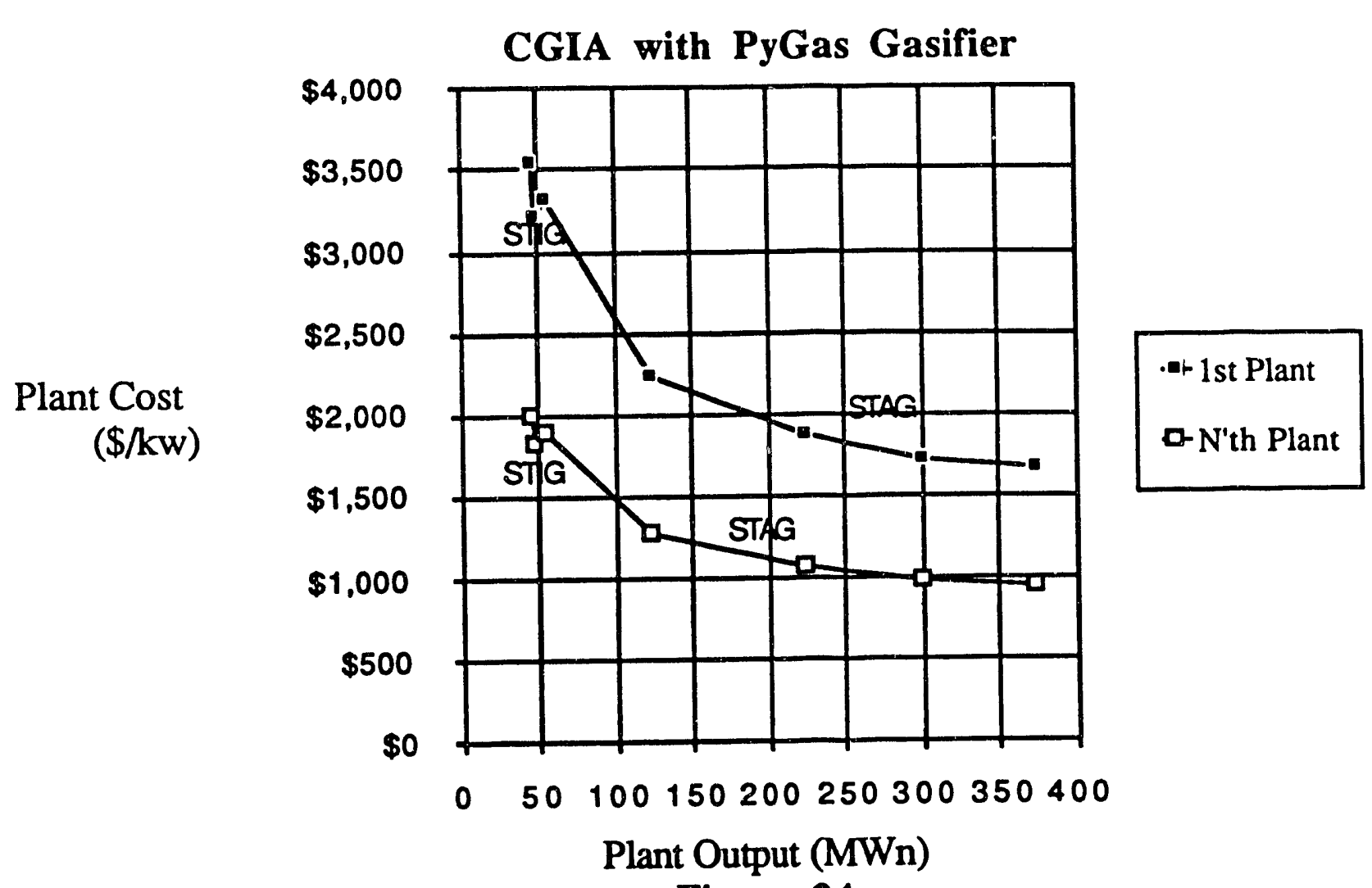

Figure 24 


\section{Cost of Electricity vs. Capacity Factor}

\section{(223 MWe CGIA GE7191F N'th Plant)}

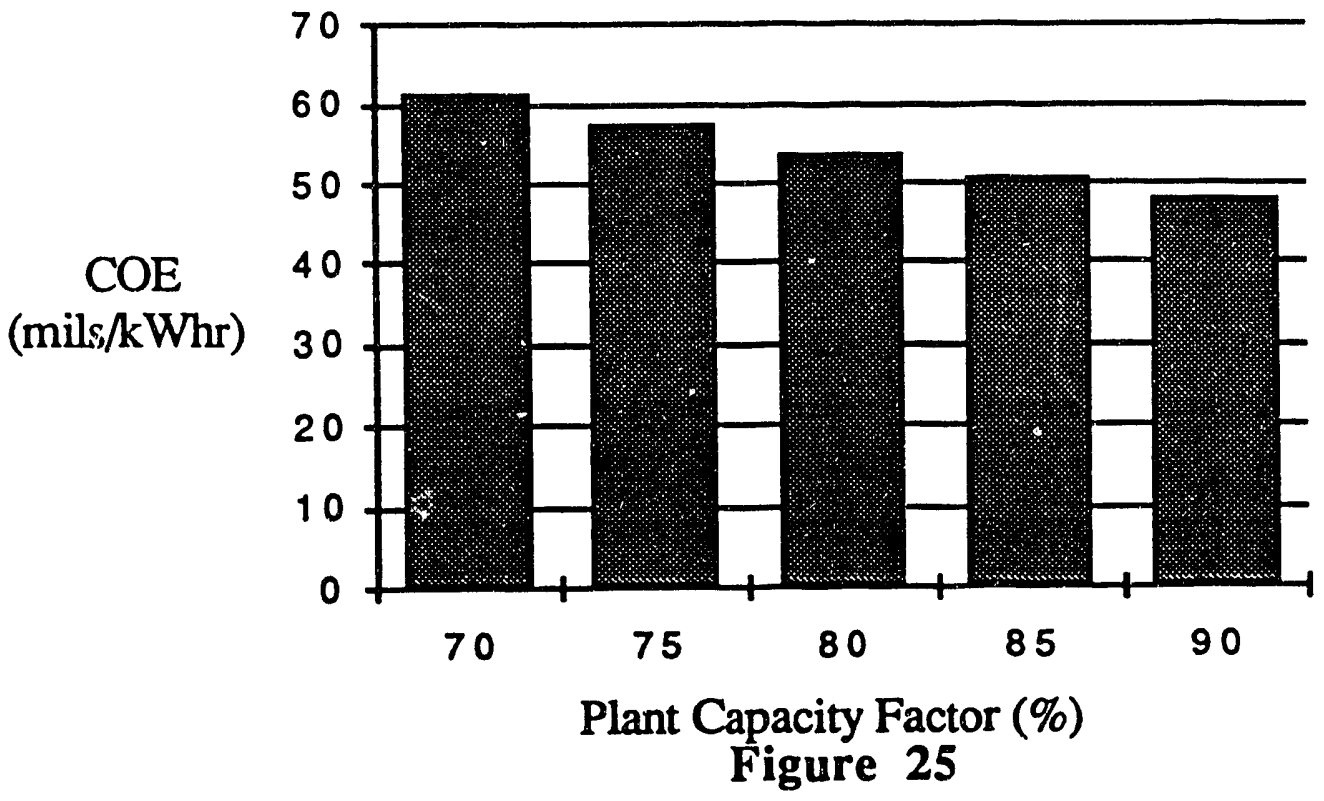

\subsection{Standardized Module Design \& Performance}

This study involved the use of both the GT-Pro [15] and MESA [16] computer programs for the determination of combustion turbine and steam boiler/turbine performance. An in-house program to identify mass and energy balances resulting from the previously mentioned programs was developed to specifically study the interrelationship of the many CGIA subsystems using both Lotus and Microsoft Excel on PC's. Several such balances appear in Appendix C. Although the study concentrated on coal gasifier relationships with the HGCU and power island, several other systems were included and considered. These include the coal briquetting plant, booster compressor, sulfur recovery processes, and various materials collection and storage points.

From a performance standpoint, only subtile differences appear between the products of the combustion turbine manufacturers with higher combustion temperatures producing slightly higher overall plant efficiencies. All arrangements studied were capable of overall plant efficiencies in excess of $39 \%$ based on higher heating value of the coal and net power output after parasitic losses (Table 11). 
The more heat utilized as thermal process load, the greater the overall plant efficiency consistent with the original intent of the PURPA laws, and FERC rules.

\begin{tabular}{lr}
\multicolumn{2}{c}{ Table 11 } \\
Auxiliary Power Losses (122.2 MWe) \\
Coal Handling \& Gasification & 559 \\
Briquetting/Binder & 397 \\
Regen Air Compressor & 780 \\
Recirc Gas Fan & 86 \\
H2SO4 Plant & 408 \\
Booster Compressor & 3,344 \\
Transformer & 723 \\
Power Cycle \& Miscellaneous & 4.186 \\
Total, kW & 10,482
\end{tabular}

Since coal as a fuel source contains less hydrogen than natural gas, it potentially can produce slightly greater overall efficiencies due to there being less moisture formed stack gas losses [14].

This study utilized existing coal gasifier test data results when determining the thermal output from the gasification process. The data utilized was generated from very small gasifiers relative to those which will be utilized on full scale applications. To account for the expected gain in the larger sized from lowered radiation losses and losses to the gasifier water jacket, this study assumed that the difference between the calculated gasifier thermal output, and the actual test data output went into gasifier water jacket steam generation. It, therefore, utilized such available heat as a source of steam generated power output.

4.3.1. Performance of the $50 \mathrm{MW}$ Size for Co-generation \& IPP

\subsubsection{STAG}

The selected nominal $50 \mathrm{MWe}$ plant typically generates $34 \mathrm{MWe}$ from the combustion turbine, $13 \mathrm{MWe}$ from the steam turbine, and $5 \%$ thermal process steam. Its overall Federal Regulatory Energy Commission (FERC) efficiency was $41.75 \%$. 
Other system information appears in the following table:

Table 12

\section{MWE CGIA PLANT}

Coal Feed Rate.

$35,688 \mathrm{lb} . \mathrm{hr}$

Air to Coal Ratio.....................................................2.41

Water Spray to Coal Ratio............................................0.26

Unfired HRSG/Steam Turbine Conditions

Flow Rate .................................... 23.6lb/sec

Pressure ........................................865 psig

Temperature.........................................800 F

Process Steam Conditions

Flow Rate ..................................... $1.94 \mathrm{lb} / \mathrm{sec}$

Pressure ......................................... 250 psia

Temperature...........................................420 F

Combustion Turbine Output ................................33.69 MWe

Steam Turbine Output......................................... 13.4 MWe

Overall Efficiency (FERC if Appropriate) .....................41.75\% 


\subsubsection{STIG}

The selected nominal $50 \mathrm{MWe}$ plant typically generates $49 \mathrm{MWe}$ from the combustion turbine, and the balance is thermal process steam. Its overall FERC efficiency was $45.92 \%$, even though it had a relatively high stack gas temperature of 314 degrees $F$.

Other system information appears in the following table:

Table 13

50 MWE CGIA STIG PLANT

Coal Feed Rate $44,280 \mathrm{lb} . \mathrm{hr}$

Air to Coal Ratio .2 .41

Water Spray to Coal Ratio. 0.26

Unfired HRSG/Steam Conditions (Dual Pressure)

Flow Rate $16.8 / 25.83 \mathrm{lb} / \mathrm{sec}$

Pressure $.600 / 250 \mathrm{psig}$

Temperature $.650 / 450 \mathrm{~F}$

Process Steam Conditions

Flow Rate $13.8 \mathrm{lb} / \mathrm{sec}$

Pressure $.250 \mathrm{psig}$

Temperature $450 \mathrm{~F}$

Combustion Turbine Output $49.0 \mathrm{MWe}$

Overall Efficiency (FERC if Appropriate) $.45 .92 \%$ 


\subsubsection{Performance of the 100 MW Sized CGIA Plant}

\subsubsection{Cogeneration \& IPP Applications}

The selected nominal $100 \mathrm{MWe}$ plant typically generates $81-85 \mathrm{MWe}$ from the combustion turbine, 46-49MWe from the steam turbine, and 5\% thermal process steam. Its overall FERC efficiency was $41.05 \%-41.72 \%$.

Other system information appears in the following table:

\section{Table 14}

100 MWE CGIA PLANT

\section{GE 7111EA $\quad$ ABB GT 11N}

Coal Feed Rate. $96,944 \mathrm{lb} . \mathrm{hr}$ $.96,707 \mathrm{lb} . \mathrm{hr}$

Air to Coal Ratio

2.41

Water Spray to Coal Ratio

0.26

Unfired HRSG/Steam Turbine Conditions

Flow Rate $78.55 \mathrm{lb} / \mathrm{sec}$ $77.52 \mathrm{lb} / \mathrm{sec}$

Pressure 1265 psig 1265 psig

Temperature $935 \mathrm{~F}$ $.935 \mathrm{~F}$

Process Steam Conditions

Flow Rate $5.42 \mathrm{lb} / \mathrm{sec}$ $.5 .33 \mathrm{lb} / \mathrm{sec}$

Pressure 250psig $250 \mathrm{psig}$

Temperature $420 \mathrm{~F}$ $420 \mathrm{~F}$

Combustion Turbine Output 84.4 MWe $.81 .1 \mathrm{MWe}$

Steam Turbine Output $46.9 \mathrm{MWe}$ $47.8 \mathrm{MWe}$

Overal! Efficiency (FERC if Appropriate) $41.72 \%$ $.41 .05 \%$ 


\subsubsection{Utility Applications}

The selected nominal 100 MWe plant typically generates 81-85 MWe from the combustion turbine, and $48-50 \mathrm{MWe}$ from the steam turbine. Its overall efficiency was $39.31 \%-39.94 \%$.

Other system information appears in the following table:

\section{Table 15 \\ 100 MWE CGIA PLANT}

GE7111EA ABB 11N

Coal Feed Rate.....................................96,944 lb.hr ...... 96,707 lb.hr

Air to Coal Ratio...................................2.41............... 2.41

Water Spray to Coal Ratio.........................0.26.............. 0.26

Unfired HRSG/Steam Turbine Conditions

Flow Rate.

$78.55 \mathrm{lb} / \mathrm{sec}$. $77.52 \mathrm{lb} / \mathrm{sec}$

Pressure 1265 psig 1265 psig

Temperature $935 \mathrm{~F}$ $935 \mathrm{~F}$

Combustion Turbine Output 84.4 MWe 81.1 MWe

Steam Turbine Output. 48.4 MWe 49.3 MWe

Overall Efficiency (Net, HHV Basis) $39.94 \%$ $39.31 \%$

\subsubsection{Performance of the $200 \mathrm{MW}$ Sized CGLA Plant}

\subsubsection{Cogeneration \& IPP Applications}

The selected nominal $200 \mathrm{MWe}$ plant typically generates $150-154 \mathrm{MWe}$ from the combustion turbine, 86-87 MWe from the steam turbine, and 5\% thermal process steam. its overall FERC efficiency was $44.83 \%-45.3 \%$. 
Other system information appears in the following table:

Table 16

200 MWE CGIA PLANT

GE 7191F MW501F

Coal Feed Rate...............................162,502 lb.hr....... 166,657 lb.hr

Air to Coal Ratio................................2.41 ................ 2.41

Water Spray to Coal Ratio......................0.26................ 0.26

Unfired HRSG/Steam T urbine Conditions

Flow Rate..............................117 lb/sec........... $116.5 \mathrm{lb} / \mathrm{sec}$

Pressure..............................1465 psig ............ 1465 psig

Temperature ...........................1000 F/1000 F...... 1000 F/1000 F

Combustion Turbine Output $.150 .4 \mathrm{MWe}$ $153.6 \mathrm{We}$

Steam Turbine Output .86.2 MWe 86.0 MWe

Overall Efficiency (FERC if Appropriate).....45.30\% $44.83 \%$

\subsubsection{Utility Applications}

The selected nominal $200 \mathrm{MWe}$ plant typically generates $150-154 \mathrm{MWe}$ from the combustion turbine, $89-90 \mathrm{MWe}$ from the steam turbine. Its overall efficiency was 43.0\%-43.47\%. 
Other system information appears in the following table:

Table 17

200 MWE CGIA PLANT

GE 7191F MW501F

Coal Feed Ratc

$162,502 \mathrm{lb} . \mathrm{hr}$

$166,657 \mathrm{lb} . \mathrm{hr}$

Air to Coai Ratio

.2 .41

Water Spray to Coal Ratio.

0.26

Unfired HRSG/Steam Turbine Conditions

Flow Rate. $117 \mathrm{lb} / \mathrm{sec}$ $116.5 \mathrm{lb} / \mathrm{sec}$

Pressure 1465 psig .1465 psig

Temperature $1000 \mathrm{~F} / 1000 \mathrm{~F} . . .1000 \mathrm{~F} / 1000 \mathrm{~F}$

Combustion Turbine Output $150.4 \mathrm{MWe}$ $153.6 \mathrm{We}$

Steam Turbine Output. 89.3 MWe 89.1 MWe

Overall Efficiency (FERC if Appropriate) $.43 .47 \%$ $.43 .0 \%$

\subsection{Financial Inputs}

4.4.1. Cogeneration and Independent Power Production

Considerable effort was placed upon generating input assumptions consistent with typical cogeneration and independent power production project development scenarios. A project pro-forma was developed as a means of checking for reasonableness of inputs based upon the principal investigator's experience with the requirements for relatively small co-generation and IPP plants developed by very small entrepreneurial companies which lack the financial strength of many larger more substantial developers. Therefore, the assumptions utilized within this study should be somewhat on the conservative side with respect to its estimates for the cost of "money". The following assumptions were incorporated into this study: 


\subsection{Owner's Cost Factors}

4.5.1. Construction Period .........................................24 Months

4.5.1. Site (Incl Rights of Way) ............................\$8,500/Acre

4.5.2. Working Capital .....................................2\% (of Construction Cost)

4.5.3. Development Recovery (of Construction Cost).......... \$2-mil (Incl permits,licenses,legal,consultants, due diligence)

4.5.4. Fuel Inventory (30 Days Dead, 7 Days Live Storage).... 37 Days

4.5.5. Financing Fees .....................................3\%

4.5.6. Spare Parts (Initial)....................................2\%

4.6. Economic Inputs (Major Only)

4.6.1. General Inflation ..................................5\%

4.6.2. Coal @ Mine (Years 1-5) ...................................5\%

4.6.3. Coai @ Mine (Years 6-20).................................8\%

4.6.4. Coal Transportation....................................5\%

4.6.5. Discount Rate...................................... 12\%

4.6.6. Interest During Construction................................ 12.5\%

4.6.7. Interest on Primary Debt .......................... 12.5\%

4.6.8. Equity After Tax Rate of Return (ATROR) .............18\%

4.6.9. Corporate \& Investor's Tax Rates ........................ 34\%

4.6.10. Property Tax Rates .................................2\%

4.6.11. Coal Fuel .................................................\$1.6/MBtu

4.6.12. Natural Gas Fuel .........................................\$3.0/MBtu

4.6.13. Catalysts...............................................4 mils/kwh

4.6.14. Disposal ..............................................\$10.31/ton

4.6.15. Operation (Fully Burdened)..............................\$73,400/man-year

4.6.16. Insurance............................................1/2\%

4.6.17. Cost of Capital

1. Debt Coverage Ratio (Min)(Opn Inc/Pri Debt) ..... 1.73

2. Subordinated Debt....................................15\%

3. Owner's Equity ...................................5\%

4.6.18. Term of Debt Service ................................... 15 Years

4.6.19. Term of Power Contract ..................................20 Years

4.6.20. Depreciation Period ..................................20 Years

4.6.21. Depreciation Amount ( $\%$ of X-key) ..................88\%

4.6.22 Capacity Factor .........................................8 80\%

4.6.23. Water ...............................................75t/1000 gal

4.6.24. Startup \& Auxiliary Fuel Usage.......................2\%

4.6.25. Elemental Sulfur Credit....................................\$105/Ton

4.6.26. Sulfuric Acid Credit.......................................\$86/Ton

4.6.27. Liquid Sulfur Dioxide Credit ......................... \$230/Ton

\section{REFERENCES}

1. "Steam Generating Units - Power Test Codes", ASME PTC4.1- 1985, ASME New York

2. "Steam-Its Generation and Use", Babcock \& Wilcox, Co.,39th Edition, New York, 1978, p-6-1 to 6-22 
3. "Combustion-Fossil Power Systems", Singer, J.G. Ed., Combustion Engineering Inc.,.Windsor, CT, 1981, p 4-1 to 4-37

4. "Design Studies for Gasification/Hot Gas Desulfurization System Operation in a Load Following Mode", Smith, D.P., DOE Contract DE-AC21-86MC22247, June 1988

5. "Equipment Availability Report, General Availability Data System", North American Electric Reliability Council, Research Park-Terhune Road, Princeton, New Jersey, 1985

6. "Coal Gasification/Cogeneration Combined Cycle Power Plant Designs", Nelson, S.G. Davy McKee, \& Bloomfield, H., NASA Lewis Research Center, Coal Technology '80, Nov., 1980

7. "TAG-Technical Assessment Guide Volume 1: Electricity Supply", EPRI P-4463-SR, Dec, 1986

8. "Conceptual Designs of Advanced High-Temperature Desulfurization Processes Volume II Integrated Gasification Combined Cycle, Final Report", Klett, M.G., et al , DOE/MC/21098--2248-Vol.2, DOE Contract DE-AC21-84MC21098, Dec, 1986

9. "Eighth Annual EPRI Conference on Coal Gasification", EPRI GS-6485 Project 1654, Electric Power Research Institute, Palo Alto, CA, Aug, 1989

10. "Personal Communication with METC", Notestein, J.E., June 11, 1990

11. "Clean Air Act of 1990", Versions have passed both US House \& Senate, Expected to Become Law in Sept, 1990

12. "Combined Cycle-Gas Turbine and Steam Generator", by Earle C. Miller, \& R. Redfern Leonard, Riley Stoker Corp., Worcester, MA, 1963

13. "NOx and Alkali Vapor Control Strategies", PSI Technology Co., Appendix B (herein) July, 1990

14. "Steam Generation from Turbine Exhaust Gas", by R.R. Leonard et al, Riley Stoker Corp., National Power Conference, Cincinnati, Ohio, September 24, 1963

15. "Diagnosis of Thermal and Fluid Dynamic Performance of a Boiler", by F. W. Bauer et al. Stone \& Webster Engineering Corporation, Technical Paper Series, 1989

16. "SO2 and NOx Retrofit Control Technologies Handbook", EPRI, Palo Alto, CA., October, 1985

17. GTPro is a Proprietary Program of Thermoflow, Inc., Waltham, Massachusetts

18. MESA is a Proprietary Program of The MESA Company, The Woodlands, Texas 


\section{Assessment of Standardized Fixed-Bed, Air-Blown Gasifier IGCC Market Acceptance}

\section{Section 5}

January 1991

Work Performed Under Contract No. DE-AC21-89MC26291

For

U.S. Department of Energy

Office of Fossil Energy

Morgantown Energy Technology Center

P.O. Box 880

Morgantown, West Virginia 26507-0880

B y

CRS SIRRINE, INC.

Power Division

P.0. Box 5456

1041 East Butler Road

Greenville, South Carolina 29606-5456 


\subsection{Summary}

This specific section is intended to evaluate advantages/disadvantages of candidate coal gasifiers matched with combustion turbine/HGCU modules. It also provides for the development and expected performance characteristics of selected advanced coal gasification systems. Included is the assimilation of empirical data and industry experience describing optimized combinations of air-blown, Fixed Bed Gasifier/HGCU/Combustion Turbine combinations.

A survey, in the form of a questionnaire, was also conducted at the 1990 Cogeneration and Independent Power Production Congress held in Boston, Massachusetts. The majority of the survey respondents had utilized coal in the past $(63 \%)$ and present $(50 \%)$, and a greater majority (75\%) expected to be burning some coal in the future. While most (75\%) believe coal is presently environmentally safe to burn, all (100\%) believe coal will be environmentally safe to burn by the year 2000 . Most (63\%) do not expect to burn more coal annually in the next ten years.

The average expected turnkey capital cost for an IGCC coal fired plant from the survey was $\$ 1340 / \mathrm{kWn}$. Additionally, the largest group (although all were ininority preferences - 23\%) would prefer to purchase their coal combustion and emissions control equipment from Babicock \& Wilcox.

Two thirds would prefer to license coal combustion and emissions control technology from the Electric Power Research Institute (EPRI). In this case, they would expect to then select their own equipment supplier who would furnish the equipment under an EPRI license.

When given a choice of environmental, efficiency, and cost factors, the respondents' were primarily cost conscious, particularly with "cost of electricity". The environment was of secondary importance, and efficiency third. The vast majority (88\%) would buy a coal fired facility if (question 8) its cost of electricity was $5 \notin / \mathrm{kwh}$, plant cost was $\$ 1,000 / \mathrm{kwn}$, FERC efficiency was $38 \%$ (or utility cycle efficiency was $41 \%$ ), it had $99 \%$ sulfur removal, its NOx emissions were $0.1 \mathrm{lb} / \mathrm{MBtu}$, and it produced elemental sulfur as a marketable waste product. 
The business and financial communities require firm guarantees of unit performance, the proof of which must be borne out under the scrutiny of their own independent "due diligence" engineering reviews. Therefore, although the " $N$ 'th" unit will be financeable, the initial units which will be required to demonstrate satisfactory performance must be innovatively developed and financed.

\section{Results IS COAL IN OUR FUTURE Results}

This questionnaire will be utilized with complete source confidentiality on U.S. Department of Energy Contract DE-AC21-89 MC 262. The results of the survey were as indicated.

\section{PLEASE CIRCLE ONE}

1. Have you (your company) in the past, do you currently, and do you plan to utilize coal as a primary fuel in the near future?

$\begin{array}{cccc}\text { past yes } & \text { currently yes } & \text { future yes } & \text { no } \\ 63 \% & 50 \% & 75 \% & 12 \%\end{array}$

2. Do you believe coal is currently environmentally safe to burn?

$$
\begin{array}{ll}
\text { yes } & \text { no } \\
75 \% & 25 \%
\end{array}
$$

3. Do you believe coal technology will be forthcoming which will make coal combustion environmentally acceptable by the year 2000 ?

$$
\begin{array}{cr}
\text { yes } & \text { no } \\
100 \% & 0 \%
\end{array}
$$

4. Do you expect your company will burn more coal annually in the next ten years?

$$
\begin{array}{cc}
\text { yes } & \text { no } \\
37 \% & 63 \%
\end{array}
$$

5. At what turnkey capital cost $(\$ / \mathrm{kw})$ would your company utilize coal fuel today?

(Average Result) $1340 \$ / \mathrm{kw}$ (net)

6. Who would you prefer to purchase the major coal combustion and emissions control equipment from?

$\begin{array}{llll}\text { Babcock \& Wilcox } & 23 \% & \text { Westinghouse } & 8 \% \\ \text { Combustion Engineering } & 8 \% & \text { Lurgi } & 0 \% \\ \text { Foster Wheeler } & 8 \% & \text { CRS Sirrine } & 15 \% \\ \text { Riley } & 0 \% & \text { Dow Chemical } & 8 \% \\ \text { General Electric } & 15 \% & \text { Doesn't Matter } & 8 \%\end{array}$


7. Would you prefer to license the technology via the Electric Power Research Institute (EPRI), or a similar organization? In this case you would select your own equipment supplier.

\begin{tabular}{|c|c|c|c|}
\hline EPRI & $\begin{array}{l}\text { yes } \\
67 \%\end{array}$ & Similar Organikation & $\begin{array}{l}\text { yes } \\
17\end{array}$ \\
\hline
\end{tabular}

8. If a coal fired plant were available today per the following description, would your company buy it?

\author{
yes no \\ $88 \% \quad 12 \%$ \\ Rank the Following in Order of Importance, 1 thru 6 \\ Number who selected \\ "Most Important" (1\&2)
}

a. Facility tumkey capital cost of $\$ 1,000 / \mathrm{kw}$

b. FERC efficiency greater than $38 \%$ (IPP \& Cogen Plants)

7

Cycle efficiency greater than $41 \%$ (Utility Steam Conditions)

c. $99 \%$ coal sulfur removal effic. (SOx less than $0.1 \mathrm{lb} / \mathrm{MBtu}$ )

d. Elemental sulfur solid waste by-product

e. NOx emissions less than $0.1 \mathrm{lb} / \mathrm{MBtu}$

f. Total cost of electricity (COE) less than $5 \phi / \mathrm{kwh}$ (levellized) 


\title{
Developments Required to Effect Commercial Gasification IGCC Applications (CGIA) Integration Into the Power Market
}

\section{Section 6}

January 1991

Work Performed Under Contract No. DE-AC21-89MC26291

\author{
For \\ U.S. Department of Energy \\ Office of Fossil Energy \\ Morgantown Energy Technology Center \\ P.0. Box 880 \\ Morgantown, West Virginia 26507-0880 \\ B y \\ CRS SIRRINE, INC. \\ Power Division \\ P.0. Box 5456 \\ 1041 East Butler Road \\ Greenville, South Carolina 29606-5456
}




\subsection{Summary}

This specific section is intended to develop the content required of a "Business Plan" to allow interested parties to implement and pursue the potential IGCC standardized plant market. It is also intended to evaluate advantages/disadvantages of candidate coal gasifiers matched with combustion turbine/HGCU modules to identify barriers to that end. It provides for the development and expected performance characteristics of selected advanced coal gasification machines as required to accommodate program objectives. Included is the assimilation of empirical data and industry experience describing optimized combinations of air blown Fixed Bed Gasifier/HGCU/Combustion Turbine combinations.

The results indicate that although. ùie anticipated firs: system costs will be relatively high, the assumption of pre-engineered standardized and modularized systems for Commercial Gasification IGCC Applications (CGIA) systems results in an "N'th unit" total facility cost of under $\$ 1,000 / \mathrm{kwn}$ in sizes larger than $200 \mathrm{MWe}$. The resultant ten year levellized cost of electricity (COE) reflected the low CGIA standardized plant cost advantage.

This study also identified existing coal fired utility power plants as near term candidates for standardized CGIA application. While many consider conventional flue gas scrubbers as the economical solution to the emissions concerns of large coal fired utilities, such systems are expensive and adversely affect power plant efficiency by consuming significant quantities of power which would have otherwise been available to the grid. In effect, while reducing stack emissions, scrubbers return reduced plant electricity output for their significant expense. Retrofitting and repowering existing coal fired power plants with CGIA results in much lower emissions than currently available commercial scrubber systems plus very substantial increased power output for the same coal input for which the facility has already been designed.

Conventional wisdom would likely suggest that successful commercialization is dependent on the ability of a new product to gain market acceptance. Such market acceptance and subsequent market penetration usually depend on a variety of factors. These typically include a well defined market, clear product definition, a 
strong marketing plan, and a vendor capable of introducing a new product to the market.

Once market and product are identified, a vendor capable of gaining market acceptance for the product within the power generation community would generally be the logical, although noi necessarily the only candidate to carry the product to commercialization. The successful vendor would possess a diverse mixture of knowledge and skills. These would ideally include a thorough working knowledge of and experience in the power generation market. The vendor must be versed in the regulations that govern the utility and independent power producers (IPP) including the Public Utility Holding Company Act (PUHCA), the Public Utilities Regulatory Policy Act (PURPA), and the revised Clean Air Act . In addition, to facilitate rapid commercial acceptance of a new power generation system, the vendor must have established credibility within the power generation community. Organizations that supply capital equipment and/or engineering services to the power generation community are strong candidates for potential vendors with established reputations.

A successful system vendor must also possess the engineering expertise to support project deyelopment and product improvement. As operating experience reveals areas for product improvement, the successful vendor must have the technical expertise to make necessary design modifications. These modifications may result in improved technical performance, system reliability, or reduced capital costs.

The successful introduction of a new product often requires a vendor to bid initial products at below cost. This is normally necessary when competing against well established technologies such as pulverized coal fired boilers with flue gas desulfurization. Due to the financial structure and highly competitive nature of IPP projects, a low bidding approach is potentially, although not the only successful way to enter the market. While lowest capital cost is not critical in utility applications, it is often the key criteria in IPP system configuration decisions. Since the rate of return is not regulated for an IPP, lower capital and O\&M costs mean higher potential profits.

In order to bid projects at or below cost, a vendor must have a sufficient asset base to subsidize market entry activities. As a result, companies that design and 
manufacture capital equipment (OEM's) may be strong candidates as potential system vendors. They have the assets and working capital necessary to fund market entry.

A vendor must have the financial strength to offer system guarantees and warranties, or be able to satisfy project financing requirements via some combination of subordinated debt provided by major equipment vendors and process guarantees provided by the commercializing entity. The financial constraints of market entry and the potential liabilities associated with project guarantees and warranties can severely limit the capability of a vendor to penetrate a market. After capturing a few initial projects, the financial exposure associated with them could severely restrict a small developer from obtaining additional project financing. This is particularly true in the highly leveraged joint owner/operator project arrangements commonly seen in the IPP market. Again, an OEM with a strong asset base might be in a better position to continue pursuing new projects. On the other hand, at least some enterprising project developers have successfully leveraged system guarantees and warranties through their major equipment suppliers. Using this scenario, they may actually be better able to spread risk than can an OEM supplier because their approach includes the entire equipment supplier base and not just one supplier.

A key characteristic of the successful vendor will be the ability to aggressively market the system to the user community. While this ability cannot be measured quantitatively when evaluating potential vendors, the company's product history is a reasonable indicator of potential success. Companies that have successfully introduced new capital equipment products in the past are likely to be versed in the aggressive approach often necessary to supplant existing technology.

Finally, a successful vendor must have the capability to fabricate and/or competitively procure the system/components. A successful vendor must be capable of controlling his competitive standing in the marketplace. This is largely dependent on the vendor's ability to control his product costing, hence pricing. A company acting as an assembler of components does not have the ability to control product pricing unless cost effective exclusive price/supply contracts are negotiated with major equipment suppliers. Otherwise, the vendor's pricing and competitiveness are largely controlled by his equipment suppliers. The capability 
to fabricate major portions of the system or to pursue alternative sources of supply ensures the vendor's ability to control his pricing relative to his competitors.

Because the market potential of this particular product is immense, and since the initial costs of such large complex systems are so high, it is likely that no single OEM will be asset rich enough to be in a position to singularly cover all the financial risk associated with bringing this system to wide commercial implementation.

The "Commercialization Plan" contemplated for this emerging product to serve a burgeoning power production market was developed with the recognition that first unit implementation looms as the greatest threat to timely introduction of this concept for widespread use in the cogeneration, independent power production, and utility industries. It includes an unorthodox approach to licensing via the Electric Power Research Industry (EPRI) or a similar independent organization capable of unbiased evaluation and sanctioning of desirable technological concepts for faster implementation of the CGIA technology scheme in the earliest possible time frame. Process guarantees are expected from the system developer while hardware and performance guarantees are from sub-system equipment manufacturers.

It is also sensitive to the ongoing developmental efforts by others such as those under the DOE's Clean Coal Technologies program. Such heroic efforts to demonstrate full scale novel clean coal utilization technologies should be lauded and supported in every conceivable way.

It is in the spirit of working along a slightly different path that this plan for commercialization takes some seemingly widely divergent (however necessary) routes to expedite the process of development, demonstration, and bringing the concept to an industry that would like to immediately implement it if it could be considered technologically proven and thus financeable.

Since additional development of a fixed-bed gasifier is currently needed before the economic goals of this study can be realized, it is believed that the cogenerdtion, independent power production, and utility industries will not endorse it until such time that the improved gasifier is demonstrated. Therefore, this study proposes 
the retrofitting/repowering of vither an existing coal fired utility facility which is perhaps nearing retirement, or a similar cogen/PP facility as the fastest route to achieve commercial status. An existing coal fired facility is appre zriate because it presumably already contains most of the infrastructure necessary to support a coal gasification endeavor.

Once commercial status is reached, it is proposed that an independent utility industry representative organization evaluate the demonstrated CGLA retrofitted plant, and using its own criteria, agrees to sanction the technology (assuming it is acceptable). The developer of the CGIA technology would then merely license the technology to the utility industry through the third party (EPRI or equal). In this manner, any utility user could select the builder of the plant who would license it through the industry representative from the CGIA developer. Therefore, if utility $A$ prefers vendor $A h$ to build the plant perhaps because vendor $A A$ previously had built the existing facility, vendor AA would pay a license fee through EPRI to the CGIA developer (similar to the way Lurgi licenses their gasifiers). The value of this scenario is its ability to immediately implement the CGIA concept simultaneously to all users through all qualified vendors. This maximizes CGIA utilization. Since the CGIA developer would provide process guarantees and equipment manufacturers the hardware and performance guarantees, the third party licensing authority would provide only their sanction of the technology (no guarantee liability).

There is solid justification for the consideration of the addition of CGIA systems to existing coal fired utility plants. The majority of the most costly of the capital cost items of the power plant already exist. These include coal receiving/handling/ storage/reclaim, water sourcing/purification/treatment/disposal, electricity generation/conditioning/distribution, and the most costly of all, the boiler island itself. Unlike other repowering strategies which require replacement of the boiler island, this study presents a way to simply add on the IGCC system to the existing coal plant with minimum modification to the existing infrastructure. The result is also an approximate $20 \%$ increase in power output while simultaneously reducing the plant's stack gas emissions by well in excess of $90 \%$ for SO2, NOx, and particulates. 


\subsection{Integration \& Matching of Commercial Gasification IGCC Applications}

The initial efforts of combining the various systems which comprise the Commercial Gasification IGCC Applications (CGIA) revolved around establishing an engineering level mass and energy balance sufficient to identify the processes involved.

Appendix $\mathrm{C}$ includes reasonably complete mass and energy balunces for the nominal $50 \mathrm{MWe}, 100 \mathrm{MWe}, 200 \mathrm{MWe}$, and utility retrofit/repower cases. Several combinations of inputted coal analyses with actual and predicted coal gasifier outputs were studied to both get an idea of ranges and constraints to be expected when changing coals.

Once satisfied that the mass and energy balances were reasonably accurate, the empirical relationships developed by others (Figure 1),[1] with actual coal gasifier operating experience of the type of gasifier selected were superimposed into the balances (both Microsoft Excel and Lotus were used to build the spreadsheets).

Gasifier sizing consistent with an expected 85\% plant availability [2] criterion was utilized. Based on previous industry experience and projections of new gasifier concepts expected to adequately deal with the adverse consequences of caking and low ash fusion coals, the typical coal throughput of a 14 foot diameter fixed-bed, airblown gasifier operating at $300-450$ psi was set at 17 tons per hour to accommodate US bituminous coals.

It was determined that it made logical senise to select available combustion turbines which, when combined with an unfired heat recovery steam generator/turbine set (Brayton plus Rankine cycles), would produce power outputs close to the three plant sizes selected for the study (STAG). Thus, the three nominal sizes became approximately $45 \mathrm{MWn}, 120 \mathrm{MWn}$, and $240 \mathrm{MWn}$. 


\section{Low BTU Gas Analysis vs. Water (GE Data) Points@ $@ 4.43 \%$ \& 6.26\% H2O are Projected}

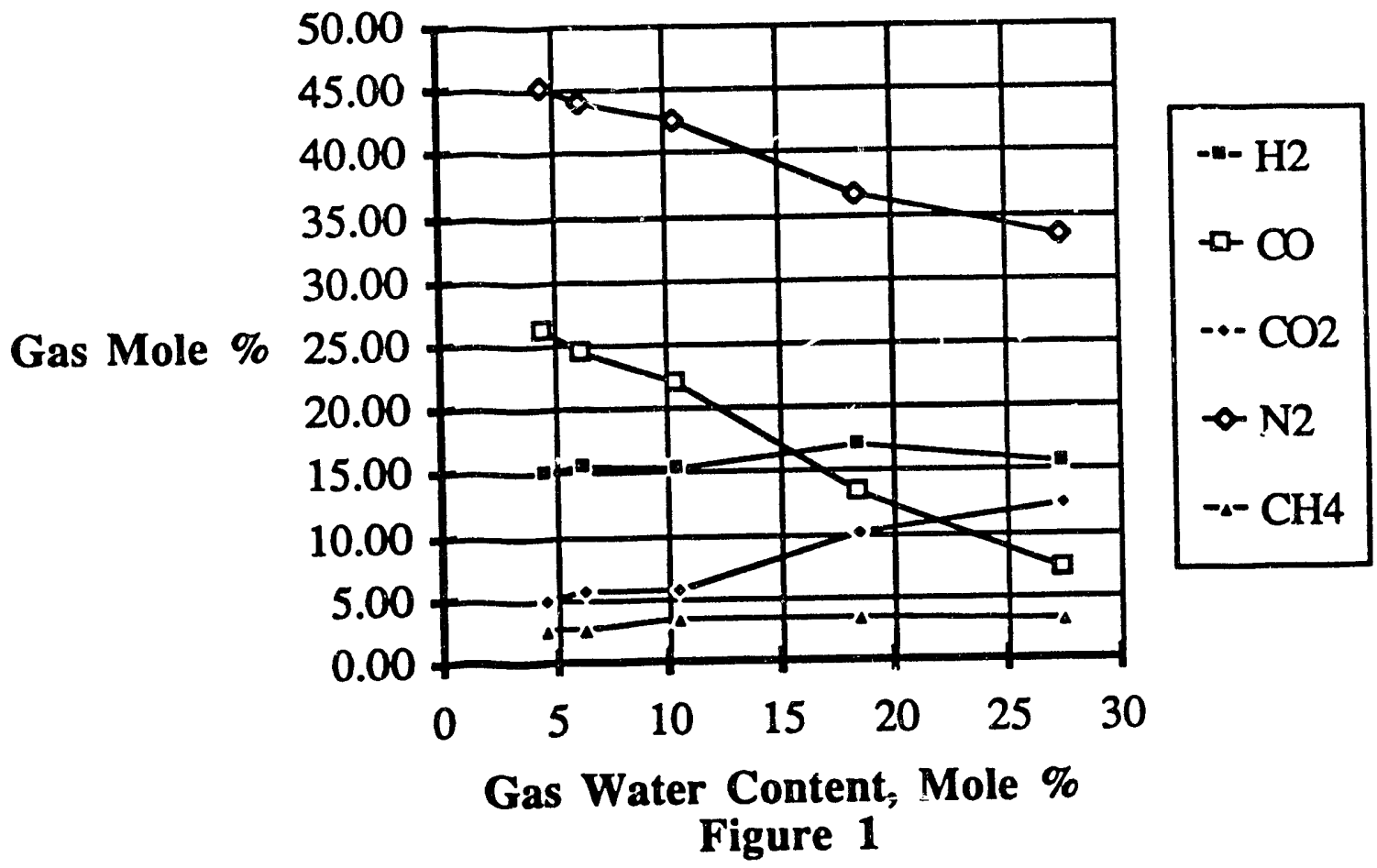

Initial cost assessments indicated that the smallest plant size was going to be uneconomical due to the relatively high equipment and development costs with respect to power output. It should be noted, however, that the smallest plant also potentially had the highest efficiency. The GE/LM 5000 PC which was selected for the $50 \mathrm{MWe}$ case was then reconsidered as a fully Steam Injected Gas Turbine (STIG) configuration. In this mode it was initially expected that the lower cost of eliminating the steam turtine and higher power output would inuprove its overall cost effectiveness. It was found that due to the high mass flows of the low BTU coal gas to the turbine combustor, the machine was steam input (hence power output) limited by surge margin limitations (3) of its manufacturer. This was especially true when high steam flows to the gasifier were needed. This limitation prompted the consideration of the use of water to the booster compressor inlet in lieu of steam to the gasifier.

The perception that cogenerators and Independent Power Producers (IPP's) are not likely to to be interested in CGIA due to its high costs in the smaller size ranges of 
interest to them, combined with the realization that utilities are currently mandated [4] to reduce emissions from their largest coal fired power plants, suggests that utilities will evalus; all available technological solutions, and will find the added MWe output from CGIA an attractive altemative to IPP's for their load growth needs.

As previously stated in Section 4, a comparison of the CGLA scheme with retrofit wet limestone scrubbers revealed tirat the "N'th" CGLA plant is less costly to install than the wet scrubber system on an evaluated basis. Such considerations as the comparative cost of the wet scrubber retrofit, a capacity credit for the additional MWe produced with the more efficient CGLA system, and an additional capacity credit for the additional parasitic power load attendant with the wet scrubber system all combined to favor the CGIA approach.

The operating costs (Table 1) reveals that the CGIA scheme has a lower fuel cost per kwhr consistent with its greater efficiency than the original coal fired power plant. The itemized per kwhr cost of the wet scrubber is automatically increased by $3 \%$ since it uses up 3\% of the plant's input energy in parasitic power draw. In addition, the wet scrubber also suffers from the cost of limestone sorbent ,

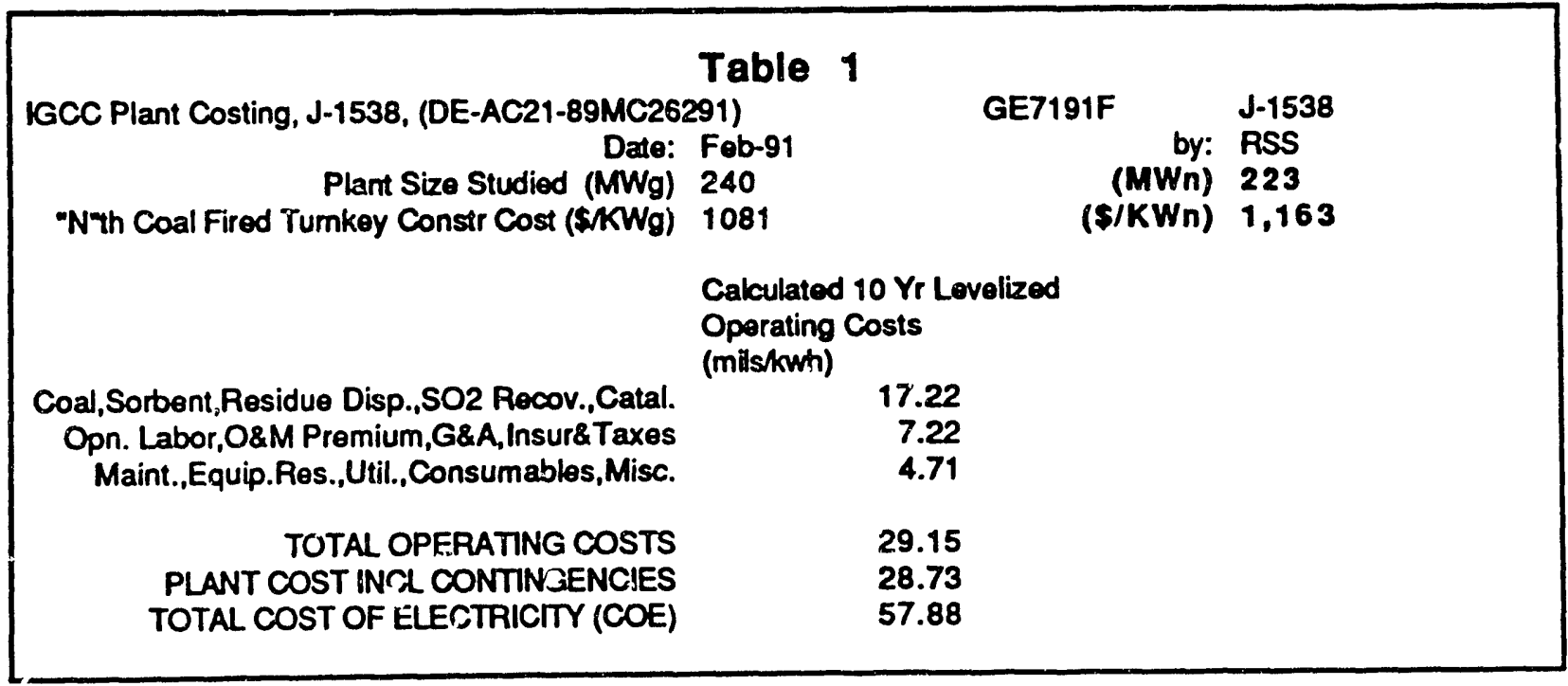

higher water consumption, and waste disposal. The CGIA is substantially credited for its elemental sulfur, sulfur dioxide, or sulfuric acid byproducts.' 
Additional benefits of the CGIA system include a reduction in total water utilization of the original coal fired plant in contrast to a significant increase in water consumption for the vet scrubber scenario. Also, the condenser/cooling tower capacity is sufficient to accommodate the flow from the additional low pressure steam turbine.

Additional efforts to develop a least cost strategy for ultimate sulfur recovery from the concentrated HGCU regeneration loop bleed SO2 stream (Appendix G) focused on the direct sulfur recovery process (DSRP), a ReSOx (TM of Foster Wheeler Energy Corp.) process substituting gasifier ash carbon for anthracite, a scaled down sulfuric acid manufacture plant (H2SO4), and direct recovery of liquid sulfur dioxide (DRISO2).

The (DRLSO2) approach was selected as the optimum short term sulfur recovery strategy. This selection was the result of a combination of favorable installation cost effectiveness coupled with current high market prices for liquid SO2. We suspect the price advantage of liquid $\mathrm{SO} 2$ is due to its broader market usefulness in contrast to either elemental sulfur or sulfuric acid (recognizing $\mathrm{H} 2 \mathrm{SO} 4$ demand far outweighs any other market use).

At present, liquid SO2 is used commercially in the pulp and paper industry for sulfite pulping, and is used as an intermediate for on-site production of bleaches. A substantial merchant market for sulfur dioxide is used in the production of chlorine dioxide at the mill site by the reduction of sodium chlorate in sulfuric acid solution and also in the production of sodium dithionite by the reaction of sodium borohydride with sulfur dioxide. It is also used for stabilization of pulp brightness after hydrogen peroxide bleaching.

In food processing, sulfur dioxide has a wide range of applications as a fumigant, preservative, bleach, and steeping agent for grain and dried fruits. It is also used in wine making to selectively destroy undesired bacteria, molds, and wild yeasts. In molasses manufacture, sulfur dioxide is used for bleaching and microbiological growth prevention. In making fructose corn syrup, sodium bisulfate from $\mathrm{SO} 2$ is added to the enzymatic isomerization step to prevent undesired microbial action. Corn syrups in the United States usually contain 15-40 ppm of sulfur dioxide. The high fructose corn syrup sweetener is an expanding market. The largest producers 
are indigenous to the mid-west USA, thus they are in close proximity to many coal fired utility plants.

In water treatment, $\mathrm{SO} 2$ is used to reduce residual chlorine from disinfection and oxidation. This technology is used in potable water treatment, sewage treatment, and industrial waste water treatment.

In the petroleum industry, $\mathrm{SO} 2$ is used as an oxygen scavenger to prevent corrosion. Sulfur dioxide acts as a catalyst modifier in certain processes for oxidation of o-xylene or naphthalene to phthalic anhydride.

In mineral technology, $\mathrm{SO} 2$ is used as flotation depressants for sulfide ores. In electrowinning of copper from leach solutions from ores containing iron, $\mathrm{SO} 2$ prereduces ferric to ferrous ions to improve current efficiency and copper cathode quality. Sulfur dioxide also initiates precipitation of metallic selenium from selenous acid, a by-product of copper metallurgy.

While this liquid sulfur dioxide market advantage may be only short term, nevertheless, it currently exists. This may be a distinct advantage for the first to N'th GCIA facility. Eventually, the market demand for $\mathrm{SO} 2$ may not be sufficient to support the supply (assuming CGIA plants 2 through $\mathrm{N}$ all produce liquid SO2). Ultimately, the greater sulfuric acid market will likely mandate that form of sulfur recovery. Since the greatest cost concern revolves around CGIA plants 1 to $\mathrm{N}$, the current economic advantage of the liquid SO2 market is used in the economic analyses in this report, while the equipment list has been expanded to include that which is needed to produce sulfuric acid.

\subsection{Standardized Module Design \& Performance Concept}

It is essential within the guidelines of this study that the CGIA concept be considered mature with an "N'th" plant cost structure. This consideration, however, begs the question as to how and when the technology will reach such maturity. In order to provide for an assumed "fast track" to maturity, this study will also assume that the CGIA concept is so well thought out that it can be completely reduced to a preengineered "standard design". There is significant precedence for such a presumption. Such entrepreneurial cogeneration and independent power producer 
companies as Cogentrix, Inc., have taken the standard plant concept to successful fruition utilizing mature stoker coal plant technology. Their results typify the cost savings potential [10] of mature standardized systems as described by EPRI's Technical Assessment Guide (TAG). A finalized design, as might be expected for a standard plant requires much less contingency than a simplified (one of a kind) design. Based upon the success of IPP's as described above, standard "N'th" plant complete modular replicative designs may save $40 \%$ of project capital cost of one of a kind plants.

An example of the potential cost effectiveness of this concept can be seen in Figure 2. In the example, an ash silo baghouse fan motor is either specified as a standardized piece of equipment which can be purchased with quantity discounts. It will produce a considerable savings in contrast to the individual plant design process which individualizes every ash silo baghouse fan motor resulting in multiple cost markups from sub-vendor to sub-vendor.

From the performance perspective, the CGLA concept lends itself to shop fabrication in 14 foot diameter truck shippable sizes. Irrespective of whether applied to aeroderivitive or stationary frame designs of combustion turbines, the gasification island can be designed for 600 psig and operated at whatever pressure is consistent with the particular combustion turbine's pressure ratio requirement. Since the system requires a booster compressor, it can be designed to overcome the coal gasification and hot gas cleanup island's system resistance to be compatible with any conceivable combustion turbine.

\subsection{1. $50 \mathrm{MWe}$ STAG Cogeneration/IPP CGIA Design}

\subsubsection{STAG}

This configuration utilizes a GE LM5000PC aeroderivitive combustion turbine with an unfired heat recovery steam generator (HRSG) at 600 psig/650F. It generates 34 MW from the Brayton cycle, plus $14 \mathrm{MWg}$ from the Rankine cycle (11). Accounting for an estimated $3 \mathrm{MWe}$ system parasitic power used, its net power generation output is approximately $45 \mathrm{MWn}$. 


\section{Plant Standardization Concepts}

\section{Example:}

A Typical

One of a Kind

Plant

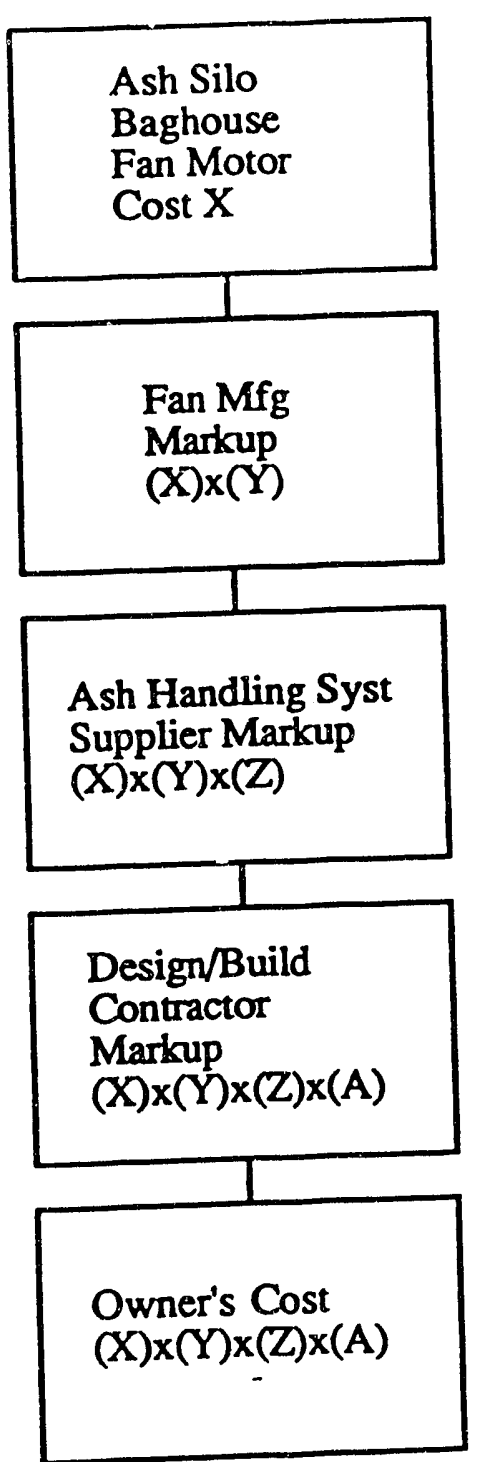

A Standardized

Multiple Application

Plant

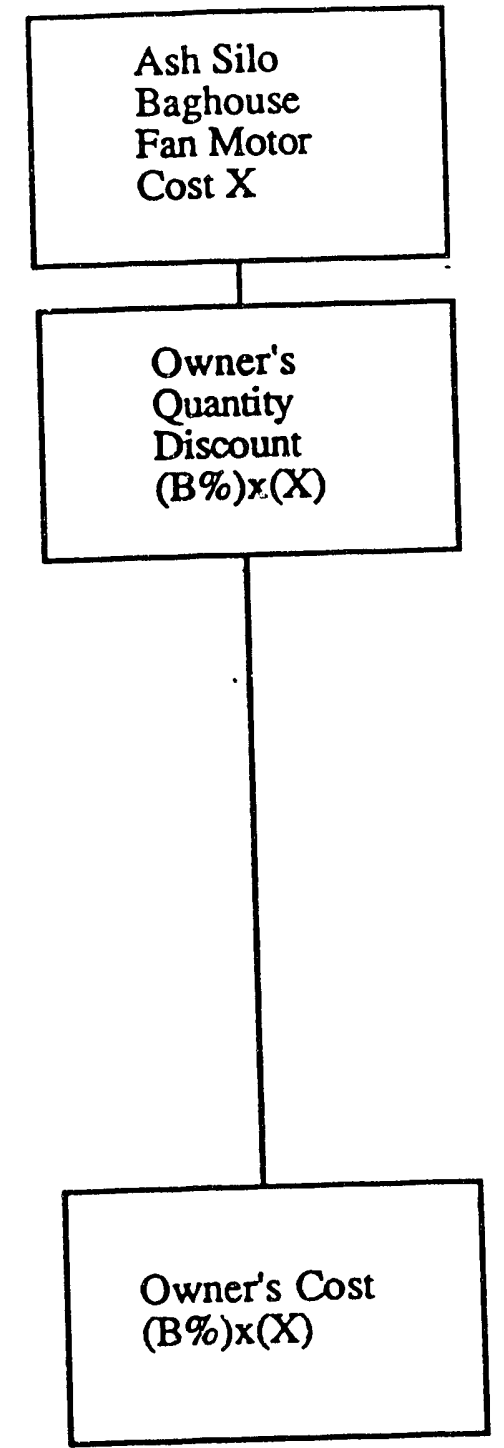

Figure 2 


\subsubsection{STIG}

An alternative STIG configuration utilizes a GE LM5000PC aeroderivitive combustion turbine with an unfired heat recovery steam generator (HRSG) at 600 psig/650F, but without a steam turbine/generator. All steam generated is injected either into the high pressure compressor, combustor, or into the low pressure section of the expander. It generates $49 \mathrm{MWe}$, all from the Brayton cycle. Accounting for an estimated $3 \mathrm{MWe}$ system parasitic power used, its net power generation output is approximately $46 \mathrm{MWn}$.

\subsubsection{Cost Sensitivity}

This smallest of the plant configurations is the most costly per unit of power output. For this reason, the consideration of the STIG configuration seemed to be a logical way to save on system cost by eliminating the steam turbine/generator. In addition, a simplified less costly coal receiving system, typical of smaller cogeneration and IPP configurations was utilized in the design. In spite of such efforts to lower the total plant costs, it appears this size CGIA concept will be most difficult to justify based on the results of the economics of this study.

The consideration of a STIG configuration improved the overall plant economics, but, even this arrangement is limited by combustion turbine surge margins. As a result, the configuration could not be operated at maximum power output even when water injection upstream of the booster compressor was utilized in an effort to reduce steam flow to the gasifier and subsequently to the combustion turbine's expander.

\subsubsection{MWe STAG Cogeneration/IPP CGLA Design}

\subsubsection{STAG}

This configuration utilizes a GE 7111EA combustion turbine with an unfired heat recovery steam generator (HRSG) at 1265 psig/935F. It generates $84 \mathrm{MW}$ from the Brayton cycle, plus $47 \mathrm{MWg}$ from the Rankine cycle. Accounting for an estimated 10 MWe system parasitic power used, its net power generation output is approximately $121 \mathrm{MWn}$. 


\subsubsection{Utility Configuration}

An alternative STAG configuration utilizes a GE 7111EA combustion turbine with an unfired heat recovery steam generator (HRSG) at 1265 psig/935F. It generates 84 MW from the Brayton cycle, plus $48 \mathrm{MWg}$ from the Rankine cycle. Accounting for an estimated $10 \mathrm{MWe}$ system parasitic power used, its net power generation output is approximately $122 \mathrm{MWn}$.

\subsubsection{Cost Sensitivity}

This configuration was considered large enough to necessitate a unit train coal receiving system, and its Rankine cycle operating conditions was somewhat limited by its unfired HRSG configuration and relatively low turbine exit gas temperatures. As a consequence, it is also economically marginal for serious consideration in contrast to more conventional systems.

\subsection{3. $200 \mathrm{MWe}$ STAG Cogeneration/IPP, Utility CGIA Design}

\subsubsection{STAG}

This configuration utilizes a GE 7191F combustion turbine with an unfired heat recovery steam generator (HRSG) at $1465 \mathrm{psig} / 1000 \mathrm{~F} / 1000 \mathrm{~F}$. It generates $150 \mathrm{MW}$ from the Brayton cycle, plus $86 \mathrm{MWg}$ from the Rankine cycle. Accounting for an estimated $16 \mathrm{MWe}$ system parasitic power used, its net power generation output is approximately $220 \mathrm{MWn}$.

\subsubsection{Utility Configuration}

An alternative STAG configuration utilizes a GE 7191F combustion turbine with an unfired heat recovery steam generator (HRSG) at $1465 \mathrm{psig} / 1000 \mathrm{~F} / 1000 \mathrm{~F}$. It generates $150 \mathrm{MW}$ from the Brayton cycle, plus $89 \mathrm{MWg}$ from the Rankine cycle. Accounting for an estimated $16 \mathrm{MWe}$ system parasitic power used, its net power generation output is approximately $223 \mathrm{MWn}$.

\subsubsection{Cost Sensitivity}


This configuration resulted in a cost effective CGIA system as shown in Figure 3. At $4.5 \notin / \mathrm{kWh}$ to $6 \notin / \mathrm{kWh}$, such a system would be very economical in many parts of the US today. Tables $2 \mathrm{a}$ through $2 \mathrm{f}$ identify the detailed cost breakdown for the 200 MWe size CGIA concept starting with known combined cycle plant costs and integrating the necessary coal and coal gasification systems.

\subsubsection{Utility Industry Applications}

\subsubsection{Retrofit/Repowering}

There is solid justification for the consideration of the addition of CGIA systems to existing coal fired utility plants. The majority of the most costly of the capital cost items of the power plant already exist. These include coal receiving/handling/ storage/reclaim, water sourcing/purification/treatment/disposal, electricity generation/conditioning/distribution, and the most costly of all, the boiler island itself. Unlike other repowering strategies which require replacement of the boiler island, this study presents a way to simply add on the IGCC system to the existing coal plant with minimum modification to the existing infrastructure. The result is an approximate $20 \%$ increase in power output while reducing the plant's stack gas emissions by well in excess of $90 \%$ for $\mathrm{SO} 2, \mathrm{NOx}$, and particulates.

Figure 3

Plant Cost Sensitivity GE7191F 223 MWe CGIA, N'th Plant

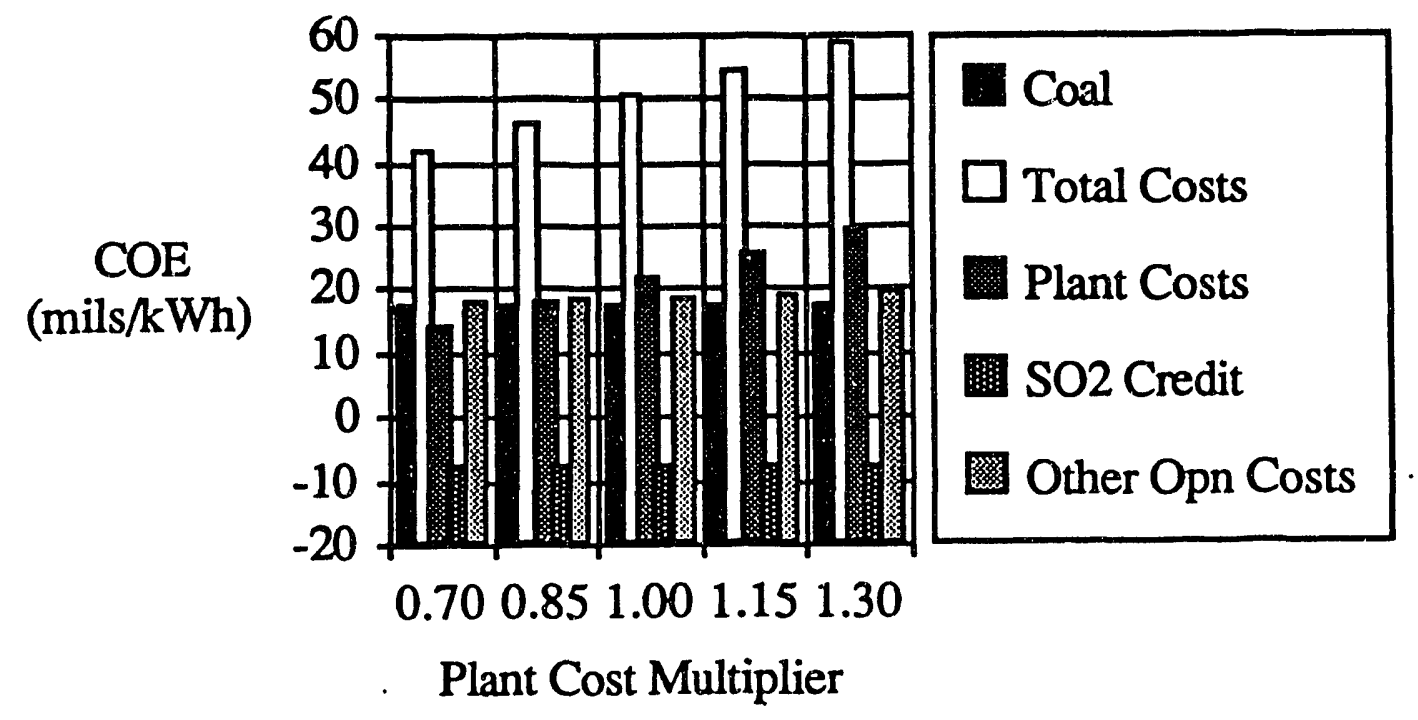


Table 2a

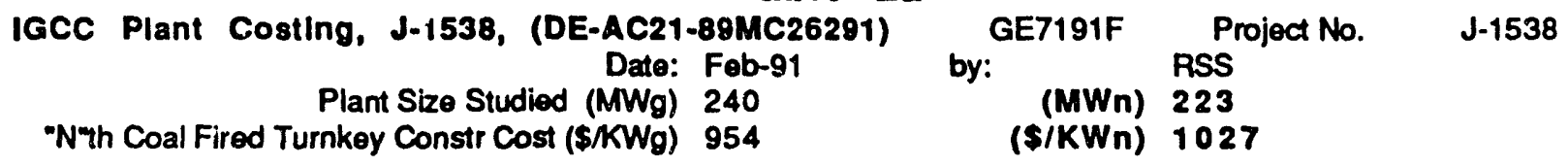

System Description: 1-Stage Dry Bottom Fixed Bed Coal Gasifiers, ZnFe Moving Bed (GE type)

1 ea, Sultur Dioxide Recovery Proc (SO2RP)

\begin{tabular}{|c|c|c|c|c|c|}
\hline Number Trains \& Section Description & $\begin{array}{c}\text { Total Flow \& } \\
\text { Units }\end{array}$ & $\begin{array}{c}\text { 1st Plant } \\
\text { SectionCost. } \\
(\$)\end{array}$ & $\begin{array}{c}\text { N-th Plant } \\
\text { Section Cost, } \\
(\$)\end{array}$ & $\begin{array}{l}\text { N-th } \\
\text { Learning } \\
\text { Reduct }\end{array}$ & $\begin{array}{l}\text { N-th } \\
\text { Plant } \\
\text { Cost } \\
(\$ / k w n)\end{array}$ \\
\hline $\begin{array}{l}1 \text { ea, Coal Handling } \\
1 \text { ea, Briquetting System } \\
8 \text { ea, Gasification \& Ash } \\
4 \text { ea, Hot Gas Cleanup System (GE type) } \\
1 \text { ea, Gas Turbine } \\
1 \text { ea, HRSG, (Includes CO Catalyst \& SCR) } \\
1 \text { ea, Steam Turbine } \\
4 \text { ea, Booster Compressor } \\
1 \text { ea, Sulfur Dioxide Recovery Proc (SO2RP) }\end{array}$ & $\begin{array}{c}28800 T P D \\
4800 \mathrm{TPD} \\
164-\mathrm{b} / \mathrm{sec} \\
164-\mathrm{b} / \mathrm{sec} \\
\text { GE7191F } \\
111-\mathrm{b} / \mathrm{sec} \\
91 \mathrm{MWe} \\
111-\mathrm{b} / \mathrm{sec} \\
9 \mathrm{~K}-\mathrm{b} / \mathrm{hr}\end{array}$ & $\begin{array}{c}11,865,859 \\
7,775,283 \\
32,947,566 \\
19,991,070 \\
48,590,000 \\
17,356,847 \\
22,041,760 \\
5,666,100 \\
9,573,649\end{array}$ & $\begin{array}{l}11,865,859 \\
6,220,226 \\
26,358,053 \\
11,994,642 \\
38,872,000 \\
17,356,847 \\
22,041,760 \\
5,666,100 \\
5,744,189\end{array}$ & $\begin{array}{c}\%) \\
0 \\
20 \\
20 \\
40 \\
20 \\
0 \\
0 \\
0 \\
40\end{array}$ & $\begin{array}{c}53 \\
28 \\
118 \\
54 \\
174 \\
78 \\
99 \\
25 \\
26\end{array}$ \\
\hline Sub-total & & $175,808,134$ & $146,119,676$ & & 655 \\
\hline BalanceofPlant(\% sub-t w/out proc conting) & $36 \%$ & $62,789,676$ & $37,673,806$ & 40 & 169 \\
\hline TOTAL PROCESS CAPITAL & & $238,597,810$ & $183,793,482$ & & 824 \\
\hline Fully Standardized Designed Nth Plant & & & $143,158,686$ & 40 & 642 \\
\hline $\begin{array}{l}\text { Engineering (Only) } \\
\text { Engineering (Contractors) Fwes } \\
\text { (Ind Proj\&ConstMgt, Testing/Startup, Design/Buik } \\
\text { (\%ofTotal Process Capital) }\end{array}$ & $\begin{array}{l}8 \% \\
21 \% \\
\text { Contr Foos, but }\end{array}$ & $\begin{array}{l}\text { 49,332,144 } \\
\text { NOT Opn, Data C }\end{array}$ & $\begin{array}{l}29,599,286 \\
\text { Col \& Rptg, Admin, }\end{array}$ & C. Dspsn) & 133 \\
\hline $\begin{array}{l}\text { Project Contingency } \\
\text { (\%oft Total Process Capital) }\end{array}$ & $13 \%$ & $31,017,715$ & $18,610,629$ & 40 & 83 \\
\hline TOTAL PLANT INVESTMENT & & $318,947,669$ & $191,368,601$ & & 858 \\
\hline $\begin{array}{l}\text { Allowance for Funds During Construction, } \\
\text { (AFDC) }\end{array}$ & $13 \%$ & $30,095,000$ & $18,057,000$ & & 81 \\
\hline $\begin{array}{l}\text { WorkCap,Taxes, Royal,Devel,Permits,Legal, } \\
\text { Fuel Inven, Spare Parts, Underwriter Costs }\end{array}$ & $10 \%$ & $23,223,371$ & $17,333,223$ & & 78 \\
\hline $\begin{array}{r}\text { Land(HistoricalSiteCostsforCo-generation) } \\
\text { Acreage @ \$8,500 per Acre = }\end{array}$ & $246^{0.7 \%}$ & $2,091,000$ & $2,091,000$ & . & 9 \\
\hline TOTAL CAPITAL REQUIREMENT & & $374,357,040$ & $228,849,824$ & & 1,026 \\
\hline
\end{tabular}




\begin{tabular}{|c|c|c|c|c|c|}
\hline $\begin{array}{r}\text { KaCC Plant Costing, +1538, (DE-AC21-89MC26291) } \\
\text { Dele: 2/5/91 } \\
\text { Plant Size Studied (MWg) } 240 \\
\text { TypicalGesFiredTumkeyConstrCoet(\$KWg) } 548\end{array}$ & Table 2b & $\begin{array}{r}\text { by: RSS } \\
(M W N) 223 \\
(E K W n) 500\end{array}$ & Projoct No. I & (SAKWn) & $\begin{array}{l}\text { Per Cont } \\
\text { ofConsts } \\
\text { (\%) }\end{array}$ \\
\hline 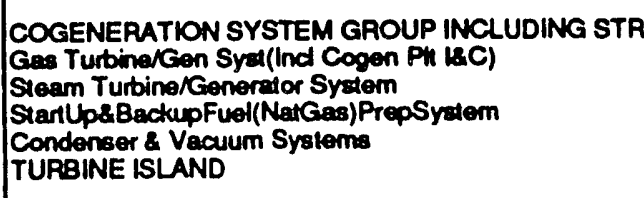 & $\begin{array}{l}\text { RD CONTROLS. } \\
\$ 27,000,000 \\
\$ 16,955,200 \\
\$ 1,650,200 \\
\$ 1,228,150 \\
\$ 46,833,550\end{array}$ & IECTRICAL, BLDG, & IL, STRUCT, ARC & RCHETEC. & MECHAN \\
\hline 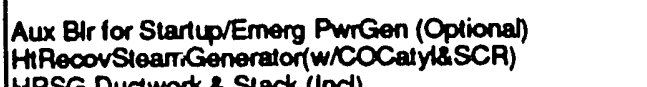 & $\$ 12,707,000$ & $\$ 3,541,673$ & $\begin{array}{r}\$ 0 \\
\$ 16,248,673\end{array}$ & & \\
\hline BOILER ISLAND & $\$ 12.707 .000$ & $\$ 4,649,847$ & $\$ 17,356,847$ & 78 & 5 \\
\hline $\begin{array}{l}\text { Cooling Tower } \\
\text { Evaporative Makoup,Circ Water,\&AuxSys } \\
\text { SUB TOT COOL'G TWR SYST }\end{array}$ & $\$ 1.770,450$ & $\$ 241,000$ & $\$ 2,011,450$ & 9 & 0.6 \\
\hline 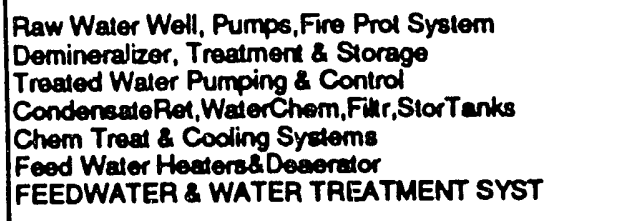 & $\$ 5,697,650$ & $\$ 1,435,856$ & $\$ 7,133,506$ & 32 & 2 \\
\hline $\begin{array}{l}\text { Genoration Plant Electrical System (Ind) } \\
\text { Sub Station, X-mrs, Switchyard (hnd) } \\
\text { and Balance of Plank Electrical } \\
\text { Powor Transmission Lines } \\
\text { SUB TOT ADDITIONAL ELECTRC SYSTEM }\end{array}$ & $\begin{array}{r}\$ 10,253,000 \\
\$ 1,100,000 \\
\$ 11,353,000\end{array}$ & $\begin{array}{r}\$ 821,486 \\
\$ 5,200,703\end{array}$ & $\$ 16,643,723$ & 75 & 5 \\
\hline $\begin{array}{l}\text { DistribrdContrSyat(DCS), ContrCntrtFacility } \\
\text { Emissions Monnitors(Additional) } \\
\text { INSTRUMENTATIONECONTRO SYSTEMS }\end{array}$ & $\$ 4,744,200$ & $\$ 1,347,595$ & $\$ 6,091,795$ & 27 & 1.8 \\
\hline BUILDINGS (Contr Rm,Lev,HVAC,CompAir) & $\$ 1,623,200$ & $\$ 725,463$ & $\$ 2,348,663$ & & \\
\hline PAINTWG/NSULAAGGGSCAFFOLDWG & $\$ 352,800$ & $\$ 103,330$ & $\$ 456,130$ & & \\
\hline COGENERATION SYST SUB TOTAL & $\$ 85,081,850$ & $\$ 25,403,005$ & $\$ 110,484,855$ & 495 & 34 \\
\hline ADD. DESIGN ENGINEERING@6\% & $\$ 8,838,788$ & & $\$ 8,838,788$ & & \\
\hline ADD. PROIECT MANAGEMENT@3\% & $\$ 2,200,607$. & & $2,209,697$ & & \\
\hline ADD. CONSTRUCTKN MGT@3\% & & $\$ 3,314,546$ & $\$ 3,314,546$ & & \\
\hline ADD. TESTG @1\% (2\% test\&strip) & $\$ 1,104,840$ & & $\$ 1,104,849$ & & \\
\hline ADD. START UP COSTS @1\% & $\$ 1,104849$ & & $\$ 1,104,849$ & & \\
\hline ADD. DESBUILD CONTRS FEE@7\% & $\$ 4,419,394$ & & $\$ 4,419,394$ & & \\
\hline SUB TOT WDIRELT COSTS & $\$ 17,677,577$ & $\$ 3,314,546$ & $\$ 20,992,123$ & 24 & 6 \\
\hline $\begin{array}{l}\text { SUB TOTAL COGENERATION } \\
\text { TURNKEY CONSTRUCTION COST }\end{array}$ & $\$ 102,750,427$ & $28,717,551$ & $\$ 131,476,978$ & 590 & 40 \\
\hline
\end{tabular}




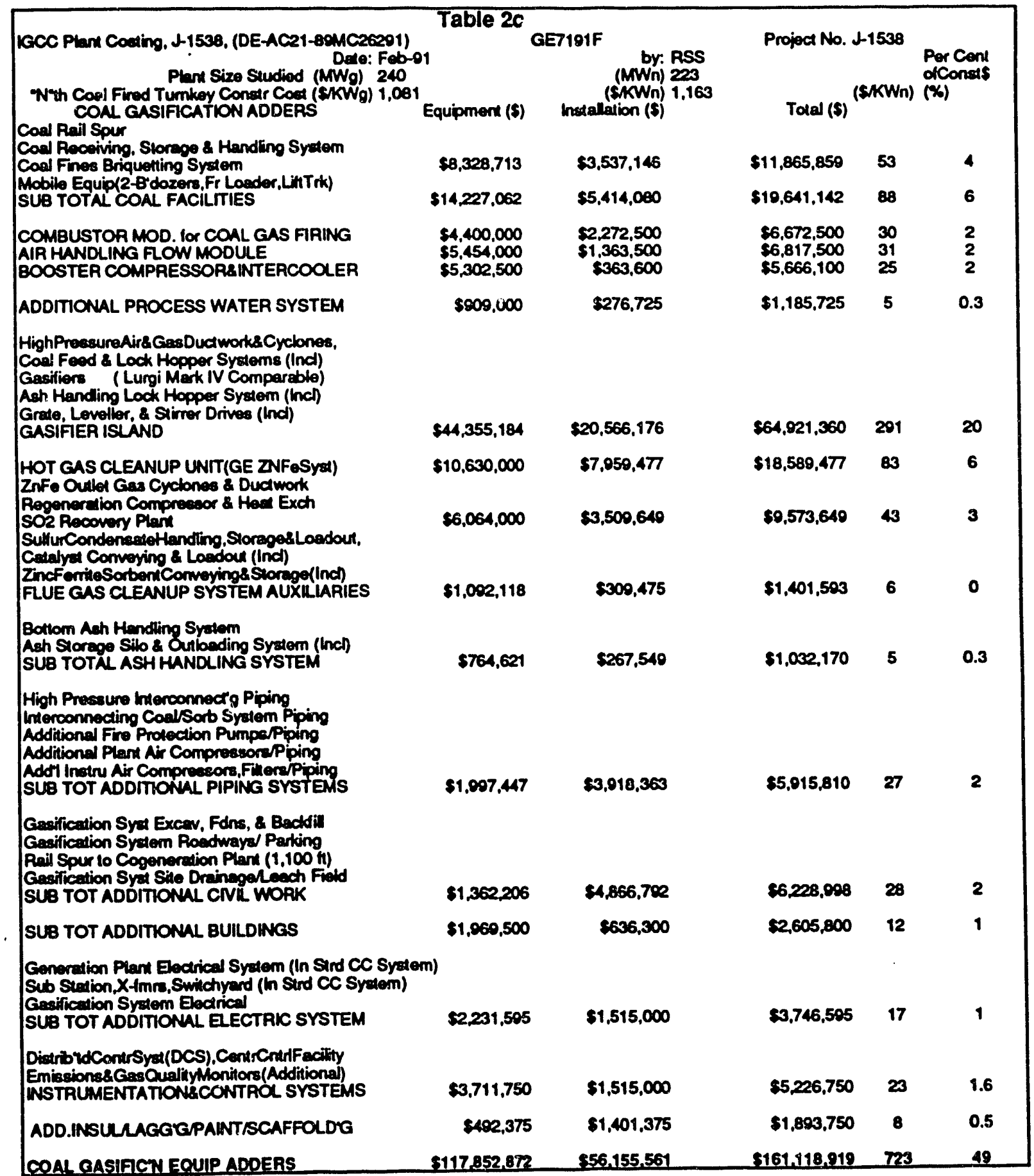




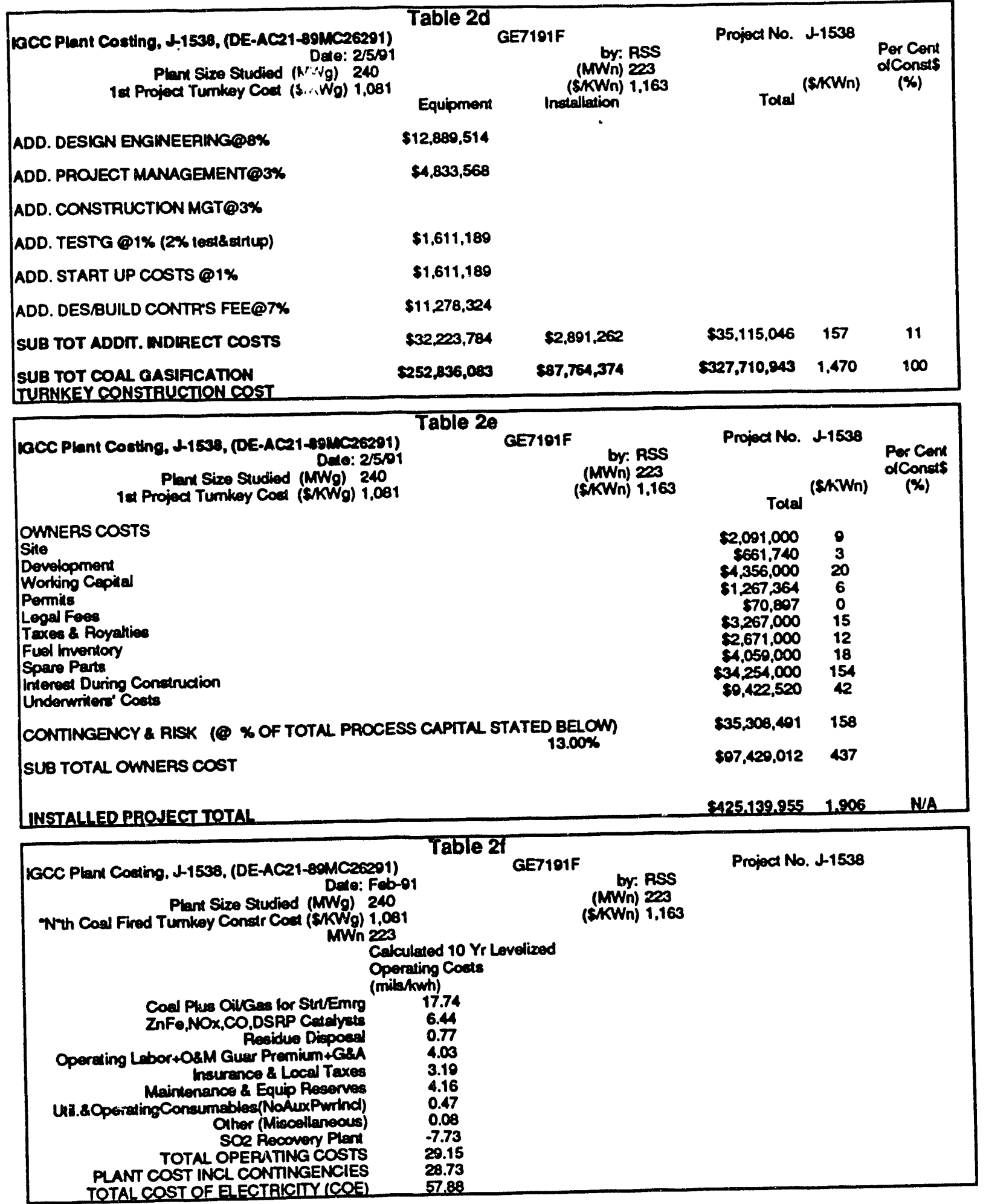




\subsubsection{New Utility Applications}

New utility applications will be more economical than retrofitted installations due primarily to the ability to employ low Btu gas fired HRSG's of the "Ranch" style since a coal fired boiler design is not necessary to burn such coal derived gas. Such boiler designs will easily address the 2400 psig/1000F SH/1000F RH cycle (perhaps with forced steam circulation), and such items as steaming economizers and low feed water temperatures can be designed into the system resulting in low flue gas exit stack temperatures. These designs will enjoy the ability to utilize staged firing and NOx reburning techniques, as well as provide for access to temperature regions where ammonia injection and selective catalytic reduction of NOx can be accomplished. There is little doubt that the ambitious goal of 0.1 $\mathrm{lb} / \mathrm{MBtu}$ of Nox emissions is achievable with this series style application of NOx control techniques.

\subsubsection{Cost Sensitivity}

Figure 4 illustrates the economy of size associated with power plant cost per kilowatt which holds true even when relatively small modular subsystems are contemplated. Modular equipment considerations enhance plant availability, and the low cost of power production from combining the most efficient of the Brayton with the Rankine thermodynamic cycles will insure the highest dispatching and capacity factors wherever the CGIA concept is utilized. 


\section{Air-Blown Fixed Bed IGCC Plant Costs}

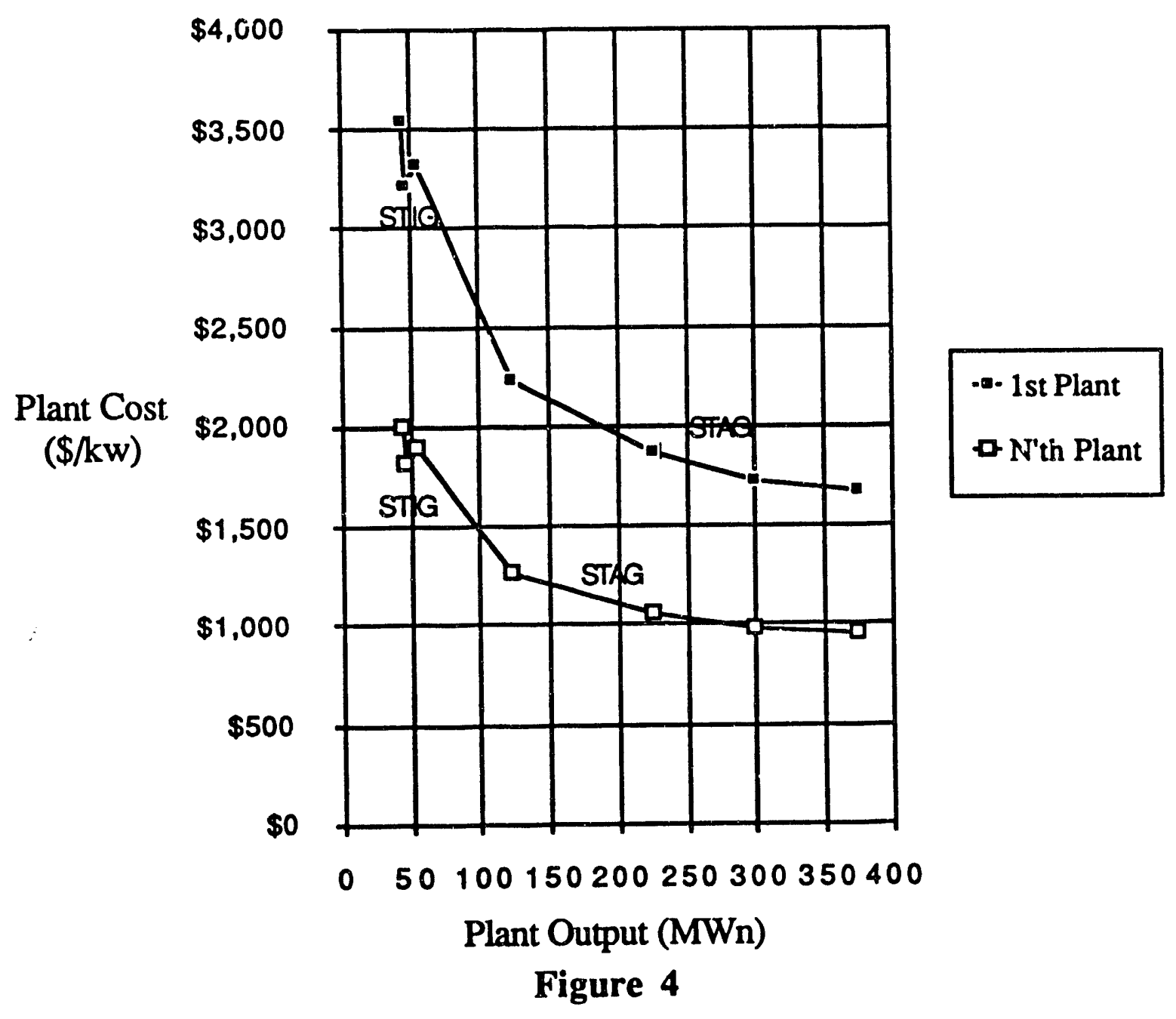




\subsection{Independent Agency Overview \& Licensing}

\subsubsection{The Licerising Concept}

\subsubsection{Electric Power Research Institute (EPRI)}

It is proposed that an independent utility industry representative organization evaluate the CGIA concept and follow its emergence as it develops through the demonstration sized retrofitted plant, and using its own criteria, agrees to sanction the technology assuming its performance is acceptable. The developer of the CGIA technology would then merely license the technology to the utility industry through thic hird party (EPRI or equal). In this manner, any utility user could select the builder of the plant who would license it through the industry representative from the CGIA developer. Therefore, if utility A prefers vendor AA to build the plant perhaps because vendor AA previously had built the existing facility, vendor AA would pay a license fee through EPRI to the CGIA developer (similar to the way Lurgi licenses their gasifiers). The value of this scenario is its ability to immediately implement the CGIA concept simultaneously to all users through all qualified vendors. This maximizes CGIA utilization. As another example, a utility user who has existing Babcock \& Wilcox pulverized coal fired boilers would likely prefer to have Babcock \& Wilcox build the CGIA add-on facility. The utility would contract with Babcock \& Wilcox, who would license CGIA technology from the EPRI and a portion of the royalty paid would flow to the CGIA developer of the standardized CGIA technology. Currently, the Lurgi Mark IV fixed-bed coal gasifier is produced in a very similar fashion. Lurgi does not build their gasifier, but rather, licenses it to users through a third organization who actually builds them under license. Although agencies like EPRI normally develop technologies and license them to suppliers, such organizations possess the appropriate expertise to evaluate and sanction useful technologies developed by others, especially where the products developed were made available to all suppliers and users alike.

\subsubsection{Altemative Agency Considerations}

Although EPRI would be a logical selection for the duty of sanctioning and licensing because they are the research and development arm of the entire utility 
industry in this country, the Edison Electric Institute (EED), Association of Edison Iiluminating Companies (AEIC), and American Public Power Association (APPA) are all capable of providing such a service although understandably, their charters might not currently contemplate such a function.

\subsubsection{The Opportunity Window}

It is believed that there currently exists an opportunity window which is not likely to present itself in the future. Some one hundred and seven (107) of the nation's largest coal fired utilities are presently being mandated to clean up their emissions from their existing facilities. This new policy has resulted in the utility industry giving new consideration as to how best to accomplish the desired end. Such potential strategies as wet scrubbers, dry scrubbers, atmospheric fluid combustion boilers, pressurized fluid combustion boilers, oxygen-blown integrated gas combined cycles, and others are all likely to be given consideration. Since the CGIA concept has so many desirable features to include low cost, it would be the concept of choice except for the fact that it is not mature enough for immediate commercialization. Any course chosen for the development of the CGIA concept must consider the present urgency of need. A great number of commercialization opportunities will be lost before and until the concept can be accelerated through development into a much needed mature state. Further development of a detailed standardized plant design should be immediately undertaken.

\section{REFERENCES}

1. "GE Data from Tests 33-1 to 34.2", General Electric, Schenectady. New York

2. "Equipment Availability Report, General Availability Data System", North American Electric Reliability Council, Research Park-Terhune Road, Princeton, New Jersey, 1985

3. "Aeroderivative Gas Turbine Performance, Emissions, and STIG", GE Turbine Reference Library, GE Power Systems, Schenectady, New York

4. "Clean Air Act of 1990", Versions have passed both US House \& Senate, Expected to Become Law in Sept, 1990 


\section{REFERENCES (continued)}

5. "Combined Cycle-Gas Turbine and Steam Generator", by Earle C. Miller, \& R. Redfern Leonard, Riley Stoker Corp., Worcester, MA, 1963

6. "NOx and Alkali Vapor Control Strategies", PSI Technology Co., Appendix B (herein) July, 1990

7. "Steam Generation from Turbine Exhaust Gas", by R.R. Leonard et al, Riley Stoker Corp., National Power Conference, Cincinnat, Ohio, September 24, 1963

8. "Diagnosis of Thermal and Fluid Dynamic Performance of a Boiler", by F. W. Bauer et al. Stone \& Webster Engineering Corporation, Technical Paper Series, 1989

9. "SO2 and NOx Retrofit Control Technologies Handbook", EPRI, Palo Alto, CA., October, 1985

10. "TAG(tm)-Technical Assessment Guide Volume 1: Electricity Supply-1986", EPRI, Palo Alto, CA, December, 1986

11. GTPro is Proprietary Program of Thermoflow, Inc., Wayland, MA 

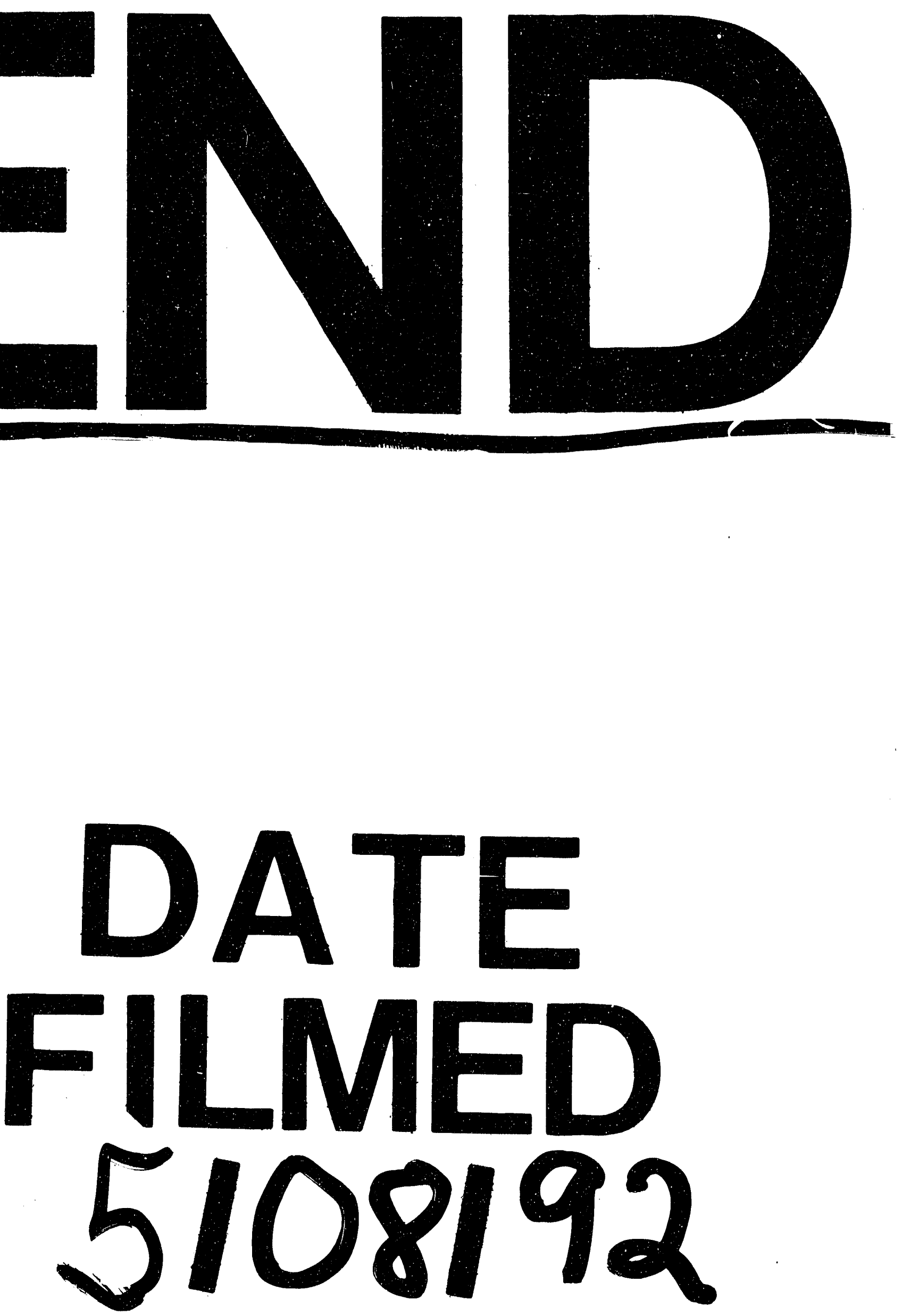


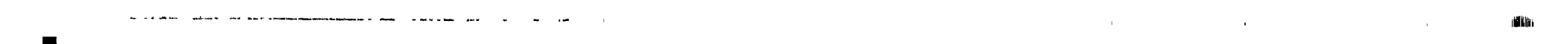

